Universidade de São Paulo

Faculdade de Filosofia, Ciências e Letras de Ribeirão Preto

Departamento de Química

Programa de Pós-Graduação em Química

\title{
Estudos das características cinéticas da fosfatase alcalina reconstituída em sistemas vesiculares
}

\author{
Ana Maria Sper Simão
}

Tese apresentada à Faculdade de Filosofia, Ciências e Letras de Ribeirão Preto da Universidade de São Paulo, como parte das exigências para a obtenção do título de Doutor em Ciências. Área: Química.

RIBEIRÃO PRETO - SP 
Universidade de São Paulo

Faculdade de Filosofia, Ciências e Letras de Ribeirão Preto

Departamento de Química

Programa de Pós-Graduação em Química

\title{
Estudos das características cinéticas da fosfatase alcalina reconstituída em sistemas vesiculares
}

\author{
Ana Maria Sper Simão \\ Orientador: Prof. Dr. Pietro Ciancaglini \\ Tese apresentada à Faculdade de \\ Filosofia, Ciências e Letras de \\ Ribeirão Preto da Universidade de \\ São Paulo, como parte das exigências \\ para a obtenção do título de Doutor \\ em Ciências. Área: Química.
}

RIBEIRÃO PRETO - SP 


\section{FICHA CATALOGRÁFICA}

Simão, Ana Maria Sper

Estudos das características cinéticas da fosfatase alcalina reconstituída em sistemas vesiculares. Ribeirão Preto, 2008.

p. 105

Tese de Doutorado, apresentada à Faculdade de Filosofia, Ciências e Letras de Ribeirão Preto/USP - Área de concentração: Química.

Orientador: Ciancaglini, Pietro

1. Fosfatase alcalina 2. Lipossomos 3. Células ghost 4 . Osteoblastos 


\section{Agradecimentos especiais}

\section{AOS MEUS PAIS,}

que nunca mediram esforços para que meus objetivos fossem alcançados.

Que sempre estiveram ao meu lado, nas horas que chorei e nas horas que sorri, e que, mesmo à distância, fizeram chegar, de diversas formas, seus incentivos e carinhoso cuidado.

A dedicação de vocês me proporcionou a tranqüilidade para estudar, que infelizmente nem todas as pessoas têm.

Serei eternamente grata pela oportunidade de estudar, pelos exemplos de caráter, honestidade e determinação, pelas palavras amigas, orações, apoio, atenção, paciência, dedicação, incentivo e amor incondicionais.

A vocês, devo todo amor, admiração e respeito.

Essa tese eu dedico a vocês!

Amo vocês! 


\section{ALESSANDRO}

Obrigada por sempre ter me incentivado a superar os desafios e ir em busca dos meus sonhos.

Obrigada pelo apoio e auxílio constantes, e por sempre me fazer entender que as coisas são sempre mais simples e fáceis do que parecem.

Obrigada por ter me dado tanta força através do seu amor, paciência e compreensão.

Sou imensamente grata por ter te confecido e me orgulho de estar ao Cado de uma pessoa como você.

Esta conquista também é sua. 
À minha irmã PATRÍCIA todo meu carinho, admiração e respeito, obrigada pela amizade, companhia, carinho, paciência e compreensão.

Aos meus familiares (avós, tios, primos....), que sempre me incentivaram e torceram por mim. Muito obrigada pela compreensão quanto ao meu afastamento e ausência em momentos especiais. Vocês estão sempre em meus pensamentos.

À minha afilhada LIV, que trás tanta luz e alegria para a minha vida, e que muitas vezes acalmou meu coração com seus carinhos, seus sorrisos e sua presença tão querida. 


\section{PIETRO}

Gostaria de expressar meu sincero carinho, admiração e respeito ao amigo e eterno mestre, obrigada pela paciência e apoio em momentos dificeis e desafiadores, pelo amparo amigo.

Obrigada por todos os ensinamentos transmitidos durante estes oito anos de convivência, pela confiança em mim depositada, pela orientação excepcional e pela amizade.

Seus conselhos e sugestões foram indispensáveis para o meu amadurecimento e crescimento profissional.

Ter você como referência é motivo de orgulho!

O OBRIGADA é pouco!

Sinceramente, obrigada por tudo! 


\section{Agradecimentos}

Aos amigos do laboratório Andréia, Carol, Hérica, Fernandinha, Imaculada, Juliana, Kátia, Larissa, Thaís, Leonardo (Tchau), Liliani, Luis Eduardo (Dudu), Marcelle, Mariana, Maytê, Prislaine, Ricardo, Ricardo (Torrone), Ro6erto (Pubs), Rodrigo (Diguinho), Rosângela, Simone, Tony, pelo companheirismo, amizade, carinho, cumplicidade, auxílios nas horas de sufoco e alegrias constantes durante todos estes anos. Com vocês, trabalho me divertindo e me divirto trabalhando! Sinceramente, muito obrigada por tudo, vocês são especiais!

$\mathcal{A}$ todos os meus amigos e amigas (ficaria difícil citar todos!) pela amizade, carinho e apoio. A todos aqueles que, embora não nomeados, me brindaram com seus inestimáveis apoios em inesquecíveis momentos, o meu reconhecido e carinhoso muito obrigado!

Aos professores Dr. Márcio Mateus Beloti, Dr. Adalberto Luis Rosa e Dr. Paulo Tambasco de Oliveira, da Faculdade de Odontologia de Ribeirão Preto - USP, pela colaboração, equipamentos, atenção e apoio.

A todos os integrantes do Laboratório de Cultura de Células do Departamento de Cirurgia, Traumatologia Buco-Maxilo-Facial e Periodontia da Faculdade de Odontologia de Ribeirão Preto - USP, que colaboraram na realização deste trabalho. Em especial, eu agradeço aos funcionários Júnia e Roger, pela amizade, atenção, paciência e suporte técnico constante. Muito obrigada por serem sempre prestativos e terem me auxiliado sempre que necessário.

Nilton e Ivana... o que seríamos de nós sem vocês!

Aos docentes, técnicos, funcionários e demais pessoas do Departamento de Química da Faculdade de Filosofia, Ciências e Letras de Ribeirão Preto - USP.

Tuca e Zé, da Faculdade de Medicina de Ribeirão Preto - USP, pelas microscopias.

À Priscila Cerviglieri pelas correções dos textos em inglês.

À FAPESP, CAPES e CNPQ , pelos auxílios concedidos ao laboratório. À FAPESP, pela bolsa de doutorado direto concedida (Processo $n^{\circ}$ 2003/06617-8).

Enfim, agradeço a todos que torceram por mim e que, de alguma forma, contribuíram para o desenvolvimento deste trabalho. 
"As pessoas estão sempre culpando as circunstâncias pelo que elas são. Eu não acredito em circunstâncias. As pessoas que progridem neste mundo são as pessoas que se levantam e procuram pelas circunstâncias que elas querem, e, se elas não conseguem encontrá-las, elas as fazem."

George Bernard Shaw 
Não somos o que sabemos. Somos o

que estamos dispostos a aprender.

Council on Ideas 


\section{Índice}

Lista de abreviaturas e siglas.

Resumo.

Abstract.

\section{Introdução}

1.1 Ossificação ou biomineralização

1.2 Fosfatase alcalina $\mathrm{x}$ lipídios e substratos.

1.3 Solubilização e reconstituição da fosfatase alcalina

1.4 Células ghost.

\section{Material e Métodos}

3.1 Obtenção e cultura de células de medula óssea de ratos.

3.2 Formação de nódulos de matriz mineralizada......

3.3 Obtenção das frações de membrana de osteoblastos.

3.4 Dosagem de proteína.

3.5 Determinação da atividade PNFFase......

3.6 Determinação da atividade ATPase.

3.7 Determinação da atividade PPase.

3.8 Determinação da atividade de fosfomonohidrolase empregando-se outros substratos fosforilados.

3.9 Centrifugação em gradiente de densidade de sacarose.

3.10 Ação de inibidores sobre a atividade da fosfatase alcalina.

3.11 Efeito do tempo de incubação com polidocanol na solubilização da fosfatase alcalina

3.12 Efeito da concentração de proteína na solubilização da fosfatase alcalina.

3.13 Efeito da concentração de polidocanol na solubilização da fosfatase alcalina.

3.14 Remoção do excesso de detergente. 
3.15 Obtenção dos extratos de clorofórmio para análise por RMN ................................ 28

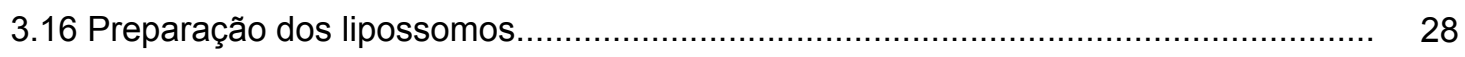

3.17 Incorporação da fosfatase alcalina em lipossomos................................................. 29

3.18 Microscopia eletrônica com marcação negativa de lipossomos e proteolipossomos.. $\quad 29$

3.19 Estabilidade dos sistemas lipossomais ............................................................... 29

3.20 Efeito do $\mathrm{pH}$ na atividade da fosfatase alcalina............................................... 30

3.21 Eletroforese em gel de poliacrilamida em condições desnaturantes (SDS-PAGE) ..... 30

3.22 Preparação das células ghost resseladas......................................................... $\quad 30$

3.23 Incorporação da fosfatase alcalina às células ghost resseladas............................... 31

3.24 Microscopia eletrônica das células ghost resseladas........................................... 31

3.25 Efeito da concentração de substratos sobre a atividade da fosfatase alcalina............ 32

3.26 Obtenção da enzima solubilizada com fosfolipase C.......................................... 32

3.27 Análise dos dados cinéticos ............................................................................ 32

\section{Resultados e Discussão}

4.1 Obtenção e caracterização da fosfatase alcalina de membrana................................. 33

4.2 Solubilização da fosfatase alcalina........................................................................ 46

4.3 Reconstituição da fosfatase alcalina em lipossomos e caracterização cinética dos sistemas de proteolipossomos........................................................................ 52

4.4 Reconstituição da fosfatase alcalina em células ghost resseladas e caracterização cinética dos sistemas fosfatase alcalina-células ghost.

5. Conclusão 


\section{Lista de abreviaturas e siglas}

ADP: Adenosina-5'-difosfato

ALP: alkaline phosphatase

AMP: adenosina-5'-monofosfato

AMPOL: 2-amino-2-metil-1-propanol

ATP: Adenosina-5'-trifosfato

ATPase: Adenosina-5'-trifosfatase

Bis-Tris: Bis[2-hidroxietil]amino-tris[hidroximetil]metano

BSA: Albumina de soro bovino

Da: Dalton

DODAB: Brometo de dioctadecildimetilamônio

DPPC: Dipalmitoil fosfatidil colina

DPPS: Dipalmitoil fosfatidil serina

GPI: Glicosil fosfatidil inositol

Hepes: Ácido N-[2-hidroxietil]piperazina-N-[2-etanosulfônico]

Imidazol: 1,3-diazo-2,4-ciclopentadieno

$\mathrm{K}_{0,5}$ : Constante de Michaelis Menten

Mes: Ácido 2-[N-morfolino]etanosulfônico

$\mathrm{n}$ : Coeficiente de Hill

PIPLC: Fosfolipase C específica para fosfatidilinositol

PNFF: $p$-nitrofenilfosfato

PNFFase: p-nitrofenilfosfatase

Polidocanol: Polioxietileno-9-lauril éter

PPase: Pirofosfatase

$P_{\mathrm{i}}$ : Fosfato inorgânico

$\mathrm{PP}_{\mathrm{i}}$ : Pirofosfato inorgânico

RMN: Ressonância magnética nuclear

SDS: Dodecil sulfato de sódio

TCA: Ácido tricloroacético

TNAP: fosfatase alcalina tecido não-específica

Tris: Tris(hidroximetil)aminometano

U: Unidade de atividade enzimática ( $\mathrm{nmol} / \mathrm{min}$ )

v: Velocidade inicial

$\mathrm{V}_{\mathrm{m}}$ : Velocidade máxima 


\section{Resumo}

A fosfatase alcalina é uma fosfomonohidrolase inespecífica, capaz de hidrolisar monoésteres de fosfato, pirofosfato, diésteres de fosfato, bem como catalisar reações de transfosforilação, e é denominada "alcalina" por sua habilidade de efetuar estas reações mais eficientemente em pH acima do neutro (pH 8-11).

O objetivo deste trabalho foi padronizar uma metodologia para a obtenção de uma fração de membrana rica em fosfatase alcalina a partir de culturas de células osteoblásticas, provenientes de medula óssea de rato, sem a utilização de solventes orgânicos, colagenase ou outras proteases. O procedimento padronizado é simples e reprodutível, com a vantagem da considerável redução do tempo necessário para se obter esta fração de membrana, o que contribui para um menor efeito desnaturante sobre a enzima.

A fosfatase alcalina é inserida à membrana plasmática por uma âncora GPI e foi solubilizada tanto com polidocanol $(1 \%, \mathrm{p} / \mathrm{v})$ quanto com PIPLC $(0,2 \mathrm{U} / \mathrm{mL})$, hidrolisando diversos substratos (PNFF, ATP, PP, ADP, $\beta$-glicerofosfato, glicose-1fosfato, glicose-6-fosfato e frutose-6-fosfato) e sendo inibida por inibidores clássicos deste grupo de enzimas (levanisol, teofilina, $\mathrm{ZnCl}_{2}$, vanadato, fosfato e arsenato).

Os efeitos de lipossomos constituídos por DPPC, DPPC:DPPS (9:1 e 8:2, razão molar) e DPPC:DODAB (9:1 e 8:2, razão molar) na habilidade tanto de inserção da enzima nos sistemas vesiculares, bem como de modulação da atividade da enzima reconstituída, também foram avaliados.

A reconstituição da fosfatase alcalina nos lipossomos mistos constituídos de DPPC:DPPS (9:1), DPPC:DPPS (8:2) e DPPC:DODAB (8:2) proporcionou máxima incorporação da atividade PNFFase da enzima (cerca de 90\%,75\% e 90\%, respectivamente) após 4 horas, 5 horas e 40 minutos, respectivamente, de incubação dos diversos lipossomos com a proteína. No entanto, utilizando lipossomos de DPPC:DODAB (9:1), apenas cerca de $50 \%$ da atividade PNFFase da enzima foi incorporada aos sistemas mesmo após 5 horas de incubação. Para os lipossomos com carga positiva, uma maior proporção de DODAB nos sistemas de DPPC favoreceu a inserção da fosfatase alcalina aos sistemas após um curto período de incubação. Para os lipossomos com carga negativa, as diferentes proporções de DPPS utilizadas não exerceram grande influência tanto na velocidade de incorporação quanto na quantidade de enzima incorporada aos sistemas. Para 
todos os sistemas utilizados, o processo de incorporação é tempo dependente.

A eletroforese dos proteolipossomos de DPPC revelou a presença de uma única banda protéica bem intensa, com massa molecular ao redor de 60 kDa (quando desnaturada), que apresentou atividade de fosfomonohidrolase em condição não-desnaturante, com massa molecular de 120 kDa. Assim, com esta estratégia, foi possível obter proteolipossomos ricos em fosfatase alcalina devido à inserção preferencial da âncora de GPI às bicamadas lipídicas, em detrimento das outras proteínas que não interagem favoravelmente com os sistemas vesiculares, comprovando que a metodologia de reconstituição padronizada pode ser usada eficientemente na obtenção de sistemas de proteolipossomos sem a necessidade de uma etapa de purificação prévia da enzima solubilizada, de modo a se obter um máximo de incorporação da enzima às vesículas com mínima perda em atividade.

A reconstituição da enzima empregando-se células ghost resseladas foi obtida incubando-se volumes iguais de enzima $(23 \mu \mathrm{g} / \mathrm{mL})$ e células ghost $(0,22$ $\mathrm{mg} / \mathrm{mL}$ ), por 2 horas, a $25^{\circ} \mathrm{C}$, com cerca de $40 \%$ da atividade PNFFase da fosfatase alcalina incorporada às vesículas.

Para verificar o efeito do microambiente da membrana sobre a atividade da enzima reconstituída, foram determinados os parâmetros cinéticos de hidrólise para diferentes substratos (ATP, $\mathrm{PP}_{\mathrm{i}}$ e PNFF). Para todos os substratos, uma única classe de sítios de hidrólise foi observada, com valores de $\mathrm{K}_{0,5}$ que variaram de 0,14 a 2,7 mM. Excesso de $\mathrm{PP}_{\mathrm{i}}$ e ATP no meio reacional inibiu as atividades PPase e ATPase da enzima reconstituída, respectivamente, em todos os sistemas estudados. A hidrólise de $\mathrm{PP}_{\mathrm{i}}$ apresentou efeitos cooperativos positivos para todos os sistemas, enquanto que para a hidrólise de ATP, uma pequena cooperatividade positiva foi observada apenas para os sistemas constituídos de DPPC e contendo DPPS em sua composição. Assim, a enzima não perdeu a habilidade de hidrolisar nenhum dos substratos quando reconstituída nos diferentes sistemas vesiculares, e todos os dados obtidos reforçam a hipótese de que a composição lipídica do microambiente onde a fosfatase alcalina se encontra exerce grande influência na modulação tanto da atividade da enzima quanto da interação da mesma com os sistemas vesiculares.

Assim, os resultados obtidos fornecem novas informações que poderão contribuir tanto para a compreensão dos mecanismos de interação da fosfatase alcalina com a membrana, quanto para estudos da função da enzima durante o processo de biomineralização. 


\section{Abstract}

Alkaline phosphatase is a multifunctional enzyme, capable of hydrolyzing phosphate monoesters, pyrophosphate, phosphodiesters, as well as catalyzing transphosphorylation reactions, and it is named "alkaline" due to its ability to perform these reactions more efficiently in $\mathrm{pH}$ above the neutral $(\mathrm{pH} 8-11)$.

The aim of this work was to standardize a methodology to obtain a membrane fraction rich in alkaline phosphatase from osteoblastic cells cultures, originated from rat bone marrow, without the use of organic solvents, collagenase or others proteases. The standardized procedure is simple and easy to reproduce, with the advantage of considerable reduction in the time needed to obtain this membrane fraction, which contributes to a smaller denaturing effect on the enzyme.

Alkaline phosphatase is a membrane-bound enzyme attached to the cell membrane via a GPI anchor and was solubilized with both polidocanol (1\%, w/v) and PIPLC $(0,2 \mathrm{U} / \mathrm{mL})$, hydrolyzing several substrates (PNPP, ATP, PP, ADP, $\beta-$ glycerophosphate, glucose-1-phosphate, glucose-6-phosphate and fructose-6phosphate) and being inhibited by some classical inhibitors of this group of enzymes (levamisole, theophylline, $\mathrm{ZnCl}_{2}$, vanadate, phosphate and arsenate).

The effect of liposomes constituted by DPPC, DPPC:DPPS (9:1 and 8:2, molar ratio) and DPPC:DODAB (9:1 and 8:2, molar ratio) on the enzyme insertion ability in the vesicular systems and activity modulation of the reconstituted enzyme were also evaluated.

The alkaline phosphatase reconstitution in the mixed liposomes constituted by DPPC:DPPS (9:1), DPPC:DPPS (8:2) and DPPC:DODAB (8:2) presented maximum incorporation of the PNPPase enzyme activity (about 90\%, 75\% and 90\%, respectively) after 4 hours, 5 hours and 40 minutes, respectively, of incubation of the several liposomes with the protein. However, using DPPC:DODAB (9:1) liposomes, only about $50 \%$ of the PNPPase enzyme activity was incorporated in the systems, even after 5 hours of incubation. For positive charged liposomes, a higher proportion of DODAB in the DPPC systems favored the alkaline phosphatase insertion into it after a short period of incubation. For negative charged liposomes, the different proportions of DPPS used did not have a big influence in both, incorporation velocity and quantity of incorporated enzyme into the systems. For all the systems used, the incorporation process is time dependent. 
SDS-PAGE of the DPPC proteoliposomes revealed only a single protein band, with molecular mass of about $60 \mathrm{kDa}$ (when denaturated), which presented phosphomonohydrolase activity under non-denaturing conditions, with molecular mass of about $120 \mathrm{kDa}$. Thus, using this strategy, it was possible to obtain proteoliposomes rich in alkaline phosphatase due to the preferential insertion of the GPI anchor in the lipid bilayers, since the other proteins do not interact favorably with the vesicular systems. This proves that the standardized methodology for reconstitution can be used efficiently to obtain proteoliposomes systems without prior purification of the solubilized enzyme, with its maximum incorporation in the vesicles and a minimum loss of activity.

The reconstitution of the enzyme using resealed ghost cells was obtained by incubating equal volumes of enzyme $(23 \mu \mathrm{g} / \mathrm{mL})$ and ghost cells $(0,22 \mathrm{mg} / \mathrm{mL})$, for 2 hours, at $25^{\circ} \mathrm{C}$, with about $40 \%$ of the alkaline phosphatase PNPPase activity being incorporated into the vesicles.

To verify the effect of the membrane microenvironment on the activity of the reconstituted enzyme, the kinetic parameters for the hydrolysis of different substrates (ATP, PP $\mathrm{i}_{\mathrm{i}}$ and PNPP) were determined. For all the substrates, only one class of hydrolysis sites was observed, with $\mathrm{K}_{0,5}$ values that varied from 0,14 to $2,7 \mathrm{mM}$. Excess of PP and ATP in the reaction medium inhibited the PPase and ATPase activities of the reconstituted enzyme, respectively, in all systems studied. $\mathrm{PP}_{\mathrm{i}}$ hydrolysis presented positive cooperative effects for all systems, while for ATP hydrolysis a small positive cooperativity was observed only for the systems constituted by DPPC and containing DPPS in its composition. Thus, the enzyme did not lose the ability to hydrolyse any of the studied substrates when reconstituted in the different vesicular systems and all the data obtained strengthen the hypothesis that the lipid composition of the microenvironment where the alkaline phosphatase is located plays a great influence on the modulation of both enzyme activity and enzyme interaction with the vesicular systems.

Thus, the results obtained provide new information that could contribute to the comprehension of the interaction mechanisms of the alkaline phosphatase with the membrane, as well as to studies of the enzyme function during the biomineralization process. 


\section{Introdução}

\subsection{Ossificação ou biomineralização}

O processo de biomineralização consiste no acúmulo de mineral constituído principalmente por íons de fosfato e cálcio que formam um sal de fosfato de cálcio, cuja estrutura se transforma em uma forma muito semelhante a da hidroxiapatita (Glimcher, 1987). O processo de ossificação mediado por osteoblastos (na formação dos ossos chatos) ou por odontoblastos (na formação do dente) é claramente distinto daquele que ocorre na calcificação da cartilagem epifisária (a partir de um modelo cartilaginoso), que é mediada por condrócitos hipertróficos. A natureza das células da matriz protéica e da interação entre a deposição de mineral e matriz protéica são claramente diferentes. Não obstante, em todos esses sistemas existe um fator comum que é a viabilização do processo de mineralização (Boskey, 1981; Wuthier, 1982, 1986; Wuthier et al., 1985; Watt, 1986; Blumenthal, 1989; Poole et al., 1989; Koboki et al., 1989; Freemont, 1993; Hsu e Anderson, 1995; Anderson, 1995, 2003; Anderson et al., 2005; Millán, 2006).

A ossificação intramembranosa ocorre a partir do tecido conjuntivo onde as células mesenquimatosas são diferenciadas em osteoblastos, que produzem matriz. Além disso, há formação de osteócitos para a manutenção da matriz (Freemont, 1993).

Nos vertebrados superiores, o processo de ossificação endocondral é o responsável pelo crescimento longitudinal da maioria dos ossos do esqueleto. Em circunstâncias normais, a biomineralização ocorre no disco epifisário pela ação de células conhecidas como condrócitos, as quais se encontram em diferentes estágios de diferenciação, dependendo, principalmente, da sua localização no interior do disco de crescimento (Anderson, 1995; Gerber e Ferrara, 2000). O disco de crescimento é composto de cartilagem, formando uma estreita faixa de ligação $(0,5$ a $1 \mathrm{~mm}$ ) entre a epífise e a diáfise, e pode ser dividido em várias regiões anatômicas: i. zona de reserva, que contém condrócitos aparentemente dispersos e inativos; ii. zona de proliferação, onde a maioria das divisões celulares ocorre. Essa região contém as células precursoras dos condrócitos (células progenitoras) em forma de disco. O nascimento de células jovens que se diferenciam em condrócitos acarreta um acúmulo de novas células que são deslocadas para baixo, formando uma coluna ao longo da zona proliferativa. A formação dessa coluna permite a subdivisão da 
matriz em septo transversal, que separa as colunas de células em diferentes estágios, e em septo longitudinal, que separa as colunas de células adjacentes; iii. a zona de maturação é a região onde os condrócitos passam de uma fase de pósdivisão a um estado de maturação. O estado de maturação é caracterizado por uma fase de intensa síntese e secreção de matriz, e é nesse local onde aparece a enzima fosfatase alcalina. A zona hipertrófica contém condrócitos aumentados e muitas vesículas da matriz. Finalmente, existe a zona de biomineralização, onde os condrócitos sofrem degeneração. É nessa região que ocorre o depósito de fosfato de cálcio no interior das vesículas, que posteriormente se extravasa infiltrando nos interstícios do septo longitudinal.

O crescimento longitudinal do osso ocorre através do equilíbrio preciso entre a proliferação dos condrócitos, produção de matriz óssea, biomineralização biológica, hipertrofia e invasão vascular da lacuna do condrócito hipertrofiado. Assim, a diferenciação dos condrócitos é a etapa crucial do processo de ossificação endocondral (Loveridge e Farquharson, 1993; Anderson, 1995; Gerber e Ferrara, 2000; Farquharson e Jefferies, 2000; Jefferies et al., 2000).

O papel dos condrócitos no disco de crescimento é fascinante devido, principalmente, ao fato de que seu período de vida é sincronizado no tempo e no local onde sua atividade é requerida. O acúmulo de resultados experimentais, ao longo desses últimos anos, tem mostrado que a hipertrofia dos condrócitos é etapa essencial para invasão vascular e subseqüente substituição da matriz calcificada por osso, sugerindo que a vascularização da região inferior do disco de crescimento representa uma etapa crucial na interação entre os processos de condrogênese (produção de cartilagem) e osteogênese (formação do tecido ósseo), principalmente durante o período de crescimento rápido dos ossos longos ou reparo de fraturas (Gerber e Ferrara, 2000). Mudanças nesse equilíbrio podem levar ao desenvolvimento de doenças esqueléticas, tais como osteoartrite, biomineralização ectópica e discondroplasia (Pizauro et al., 2002).

Atualmente, admite-se que o brotamento das vesículas da matriz representa um intrigante mecanismo de geração de organelas extracelulares, cuja função é a de realizar as etapas finais do processo de biomineralização antes da morte programada dos condrócitos por apoptose (Kirsch e Wuthier, 1994; Anderson, 1995; Kirsch et al., 1997; Kirsch et al., 2000; Wang et al., 2003).

Os eventos bioquímicos e biofísicos responsáveis pela biogênese das 
vesículas extracelulares ainda não estão perfeitamente elucidados, mas admite-se que eles estejam relacionados com o ciclo de vida dos condrócitos e, possivelmente, com o seu processo de apoptose (Anderson, 1995; Kirsch et al., 1997; Adams e Shapiro, 2002; Shapiro et al., 2005). Recentes estudos têm demonstrado que a apoptose dos condrócitos é mediada tanto pela concentração de íons cálcio como pelos níveis de fosfato inorgânico nos sítios de mineralização (Mansfield et al., 1999, 2001, 2003; Adams e Shapiro, 2002; Magne et al., 2003).

Um dos grandes desafios da biologia é a compreensão de como as células se replicam e se dividem, e um dos aspectos importantes desse problema é saber como as células formam as vesículas extracelulares. A nova vesícula deve ser formada com grande precisão e possuir todas as informações necessárias para criar um microambiente adequado para a formação e preservação de mineral de hidroxiapatita (Anderson, 1995; Kirsch et al., 1997).

As vesículas surgem por brotamento das superfícies laterais dos condrócitos e são secretadas no local específico do início da biomineralização da matriz do tecido ósseo (Kirsch et al., 1997). Nos osteoblastos, as vesículas surgem da membrana plasmática adjacente à matriz óssea recentemente formada, e nos odontoblastos, na porção apical da célula que se encontra em contato com a matriz da pré-dentina. O papel dessas vesículas como mediadoras da deposição mineral é fortemente sugerido pelos seguintes fatos: o local de aparecimento de depósitos minerais tem exata correspondência com o local das vesículas (Anderson, 1973; Ali, 1976; Hsu e Anderson, 1978; Martino et al., 1979), os primeiros cristais na forma de pequenas agulhas ou de bastão, que precedem o crescimento do cristal extracelular, têm sido detectados dentro dessas vesículas (Bonucci, 1971; Ali e Evans, 1973; Anderson, 1973, 1976, 1995, 2003; Wuthier, 1977; Wuthier et al., 1985; Sela et al., 2000). Além disso, tem sido proposto que o interior das vesículas também serve como um microambiente selado, que protege o primeiro núcleo do mineral, enquanto ainda está em um estado pré-cristalino mais solúvel, antes de se converter em um cristal de hidroxiapatita. Tem sido verificado ainda que as vesículas isoladas também possuem a capacidade de depositar sais de cálcio in vitro (Ali e Evans, 1973; Hsu e Anderson, 1977, 1978, 1986; Register et al., 1984; Wuthier e Register, 1985; Derfus et al., 1998; Garimella et al., 2006; Ciancaglini et al., 2006; Millán, 2006).

Outro aspecto a ser considerado é que o processo de ossificação endocondral pode ser reproduzido experimentalmente in vivo através do implante de 
matriz óssea desmineralizada (Reddi e Huggins, 1972), ou pelo implante de proteína morfogênica, extraída do tecido ósseo, no tecido subcutâneo de ratos (Urist et al., 1973), ou ainda pelo implante de proteína morfogênica ou matriz óssea desmineralizada associada com plasma enriquecido em plaqueta (Marx et al., 1998). Reddi e Huggins (1972) demonstraram que o implante de matriz óssea desmineralizada em tecido subcutâneo de ratos age como um estímulo que desencadeia um processo de diferenciação e organização celular, levando à formação seqüencial de cartilagem e osso. Os estudos histológicos e bioquímicos envolvidos no processo de biomineralização ectópica dessas placas, via ossificação endocondral, foram descritos por esses mesmos autores, que observaram uma estreita correlação entre a atividade da fosfatase alcalina e os sítios histológicos de formação do tecido ósseo (Leone et al., 1997a).

Entretanto, atualmente o uso de cultura de células vem ganhando espaço por apresentar ainda mais vantagens: (1) a possibilidade de se estudar as células de interesse em um ambiente mais controlado, tanto com relação às condições fisiológicas (constituintes do meio, interação célula-célula, etc.) como físico-químicas (concentrações de solutos, $\mathrm{pH}$, temperatura, tensão $\mathrm{CO}_{2}$, etc.); (2) as células podem ser diferenciadas e caracterizadas, tornando a amostra mais homogênea quando comparada com experimentos in vivo; (3) as culturas podem ser expostas a concentrações de drogas menores, mais exatas e com acesso direto às células; (4) permite a redução de experimentos com animais e sua conseqüente implicação ética (Ochoa e Vacanti, 2002).

\subsection{Fosfatase alcalina $x$ lipídios e substratos}

Até agora, têm sido identificadas três moléculas presentes em osteoblastos que afetam a deposição controlada de mineral ósseo, por meio da regulação dos níveis de $\mathrm{PP}_{\mathrm{i}}$ extracelular: fosfatase alcalina tecido não-específica (TNAP), NPP1 (uma isoenzima nucleotídeo pirofosfatase/fosfodiesterase) e o produto do gene ANK.

As fosfatases alcalinas pertencem a uma família multigênica que codifica diferentes formas da enzima, distribuídas em quase todos os tecidos. No homem e nos primatas superiores, três isoformas distintas têm sido identificadas: a da placenta, a do intestino e a do fígado-osso-rim (Lowe et al., 1990; Le Du e Millán, 2002). As isoformas da placenta e do intestino são tecido-específicas e são expressas unicamente na placenta e no intestino, respectivamente, enquanto a 
isoforma do fígado-osso-rim é encontrada em quase todos os tecidos, sendo também denominada por esta razão de fosfatase alcalina tecido não-específica (TNAP). Além disso, níveis elevados desta isoforma têm sido encontrados, também, nas membranas dos osteoblastos durante a formação e a mineralização do tecido ósseo (Wuthier e Register, 1985; Nakamura et al., 1988; Anderson, 1995; Hsu e Anderson, 1995).

As fosfatases alcalinas catalisam a seguinte reação geral:

$$
\mathrm{R}-\mathrm{OP}+\mathrm{H}_{2} \mathrm{O} \longrightarrow \mathrm{R}-\mathrm{OH}+\mathrm{P}_{\mathrm{i}}
$$

onde a hidrólise de R-OP origina fosfato inorgânico $\left(P_{i}\right)$ e um álcool, açúcar, fenol etc. Portanto, são membros da classe de enzimas conhecidas como fosfomonoesterases, e são denominadas "alcalinas" por sua habilidade de efetuar esta reação mais eficientemente em pH acima do neutro ( $\mathrm{pH}$ 8-11).

A fosfatase alcalina de diversos tecidos de mamíferos é uma fosfomonohidrolase inespecífica (E.C.3.1.3.1), capaz de hidrolisar em $\mathrm{pH}$ alcalino monoésteres de fosfato (ATP, ADP, AMP, p-nitrofenilfosfato, glicose-6-fosfato, glicose-1-fosfato, gliceraldeído-3-fosfato), pirofosfato, diésteres de fosfato (bis-pnitrofenilfosfato e AMP-cíclico), bem como catalisar reações de transfosforilação (McComb et al., 1979; Hsu et al., 1985; Curti et al., 1987; Pizauro et al., 1987, 1992, 1993, 1995; Ciancaglini et al., 1990a; Rezende et al., 1994, 1998; Leone et al., 1997a, 1998). De fato, as características cinéticas obtidas para diferentes formas da enzima, de variados tecidos, empregando-se diferentes substratos, têm sido investigadas e comparadas (Fortuna et al., 1979; Cyboron e Wuthier, 1981; Curti et al., 1986; Ciancaglini et al., 1990a; Pizauro et al., 1995; Leone et al., 1998; Rezende et al., 1998; Ciancaglini et al., 2006; Millán, 2006; Simão et al., 2007a,b).

Independentemente de sua origem, as fosfatases alcalinas são enzimas homodiméricas e cada sítio catalítico contém três íons metálicos (dois íons Zn e um íon Mg), necessários para a atividade da enzima (Millán, 2006). Um novo sítio nãocatalítico que se liga a um metal e parece ser ocupado por cálcio foi descoberto após a resolução da estrutura tridimensional da fosfatase alcalina de placenta (PLAP) (Le Du et al., 2001; Mornet et al., 2001). A importância estrutural e funcional deste novo sítio metálico ainda não foi elucidada, mas a descoberta de sua existência confirma estudos anteriores que indicavam que, em cartilagem, a fosfatase alcalina era uma glicoproteína ligadora de $\mathrm{Ca}^{2+}$ (De Bernard et al., 1986). 
Os estudos referentes à participação da fosfatase alcalina no processo calcificação têm demonstrado a presença de duas formas de enzima, uma associada à membrana e outra solúvel. Embora existam controvérsias em relação ao papel fisiológico da fosfatase alcalina, somente a forma ligada à membrana tem sido associada ao processo de calcificação (Cyboron e Wuthier, 1981; Wuthier e Register, 1985; Curti et al., 1986; Say et al., 1991; Leone et al., 1997a).

O papel fisiológico da fosfatase alcalina no processo de calcificação não é claro devido às dificuldades de extração da enzima de tecidos ósseos e/ou cartilaginosos e sua subseqüente solubilização. Os vários métodos descritos para a extração e purificação da fosfatase alcalina de diversos tecidos geralmente envolvem o uso de colagenase (Radisson et al., 1996) e/ou solventes orgânicos (Angrand et al., 1997; Morandat et al., 2002). Tais métodos, apesar de apresentarem uma eficiência relativamente boa, possuem algumas restrições em relação ao seu uso, pois podem alterar a estrutura da proteína, sua atividade catalítica e propriedades essenciais para o processo de mineralização (Fortuna et al., 1979; Cyboron e Wuthier, 1981; Hsu et al., 1985; Angrand et al., 1997). De fato, atividades dez vezes menores do que a descrita para a enzima ligada à membrana obtida de osteoblastos (Simão et al., 2007a) têm sido relatadas para a fosfatase alcalina associada à membrana obtida pelo tratamento de cultura osteoblástica humana com colagenase (Radisson et al., 1996; Gonçalves et al., 2002), e para a enzima extraída de intestino bovino solubilizada com solventes orgânicos (Angrand et al., 1997).

Curti e colaboradores (1986) desenvolveram um método simples, rápido e eficiente de obtenção e purificação de quantidades significativas de fosfatase alcalina de cartilagem induzida por matriz óssea, abolindo tratamentos drásticos que poderiam afetar a integridade da enzima. Apesar de este método ter trazido significativa melhora com relação à estrutura da enzima isolada, ele apresenta a desvantagem de ter que preparar a matriz óssea ácido insolúvel e efetuar um implante que irá induzir ectopicamente a formação de osso.

Assim, um dos benefícios da metodologia aqui apresentada é que um simples procedimento de homogenização e ressuspensão é necessário para se obter a fração de membrana rica em fosfatase alcalina derivada de culturas de osteoblastos, evitando-se a utilização de proteases e/ou tratamento com solventes orgânicos, o que contribui para um menor efeito desnaturante na enzima. Uma outra característica importante desta técnica é a facilidade de realizar testes in vitro que 
possam simular situações in vivo que eventualmente ocorram durante o processo de mineralização.

Há cerca de vinte anos foi demonstrado que a fosfatase alcalina, bem como outras enzimas (5'-nucleotidase e a colinesterase), não são proteínas integrais da membrana lipoprotéica, mas estão associadas à membrana por uma âncora de fosfatidilinositol. A estrutura da âncora resulta em mobilidade lateral na membrana e permite a liberação da proteína da membrana pela ação de fosfolipases (Pizauro et al., 1995; Leone et al., 1997a; Millán, 2006). Esta descoberta surgiu pelo fato de que a fosfatase alcalina podia ser removida da membrana através de um tratamento com uma fosfolipase C específica para fosfatidilinositol. Além disso, tem sido verificado que a fosfolipase $\mathrm{C}$ pode remover a região hidrofóbica das proteínas solubilizadas com detergentes ou com solventes orgânicos (Low e Finean, 1978; Low et al., 1986; Hawrylak e Stinson, 1987; Ferguson et al., 1988; Ciancaglini et al., 1989, 2006; Pizauro et al., 1994, 1995; Radisson et al., 1996; Camolezi et al., 2002).

A disposição dos constituintes da âncora de fosfatidilinositol associada à membrana tem sido estudada e caracterizada através da sua liberação da membrana pelo tratamento com fosfolipase $C$, seguida de análise química detalhada da região da âncora. Este tratamento tem sido utilizado como uma grande evidência experimental da participação dessa âncora de fosfatidilinositol na associação de proteínas com a membrana lipídica (Low et al., 1986, 1987; Low e Saltiel, 1988).

Atualmente, o modelo mais completo proposto para a estrutura de uma âncora de fosfatidilinositol apresenta três regiões distintas: (1 uma molécula de fosfatidilinositol ligada à molécula de 1,2-diacilglicerol, que se encontra embebida na camada lipídica da membrana; 2 uma glicana de composição variável, ligada através de uma ligação glicosídica a uma molécula de fosfatidilinositol; 3 uma molécula de etanolamina ligada à extremidade não redutora da glicina e ao grupamento carboxílico terminal da proteína (Low et al., 1986, 1987; Low e Saltiel, 1988).

É importante salientar que, no caso das proteínas solubilizadas com detergentes ou solventes orgânicos, a porção hidrofóbica da âncora de fosfatidilinositol pode ser removida não somente pelo tratamento com fosfolipase $C$ (Low et al., 1987; Kihn et al., 1990; Takesue et al., 1989), mas também pela papaína (Seetharam et al., 1987; Takesue et al., 1989) e pela bromelina (Howard et al., 1987). Além disso, tem sido relatado que as proteínas solubilizadas através de 
tratamento com detergente ou com proteases possuem o mesmo dipeptídeo $\mathrm{N}$ terminal, sugerindo que a liberação da enzima da membrana ocorre através da hidrólise do grupamento carboxílico terminal (Colbeau e Maroux, 1978; Low et al., 1987).

3

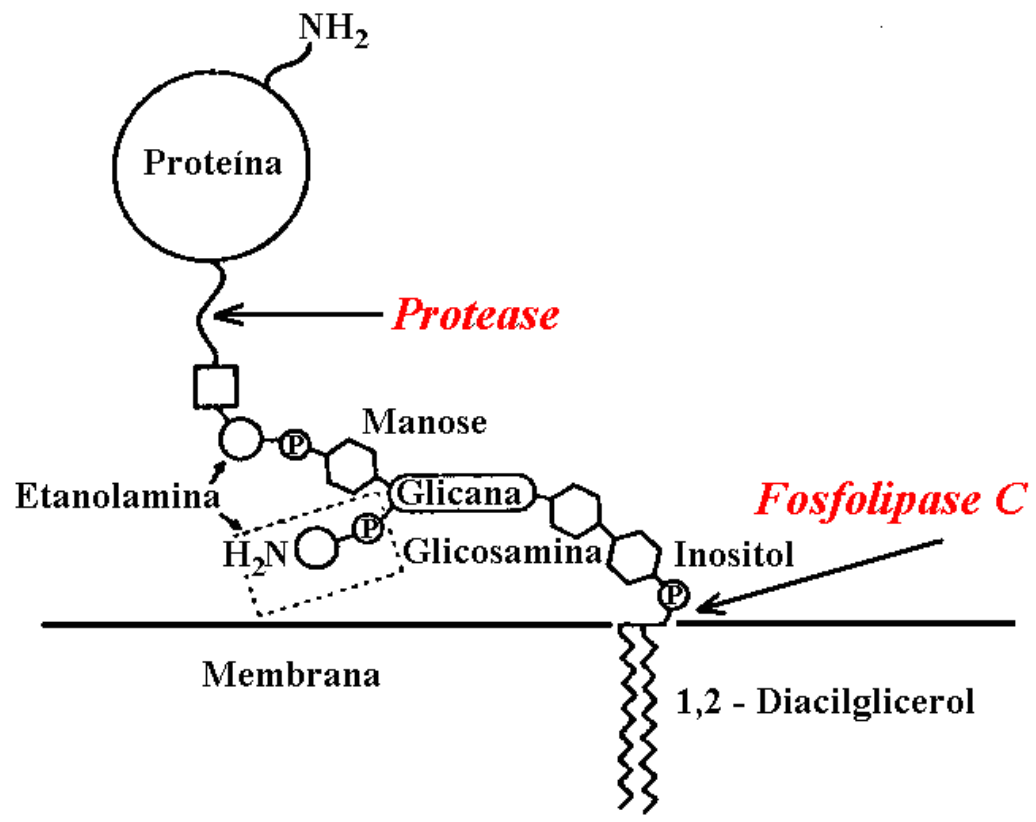

Evidências de que os lipídios podem estar envolvidos em alguma fase do processo de mineralização já foram obtidas através de estudos histoquímicos (Itving, 1973). Além disso, Wuthier (1975) revelou que elevados níveis de colesterol, esfingomielina, fosfatidilserina, monoacil-colina-fosfoglicerol, diacil-colinafosfoglicerol, serina-fosfoglicerol e etanolamina-fosfoglicerol podem ser encontrados em membranas de condrócitos, osteócitos e vesículas da matriz. Roberts e colaboradores (2004) também demonstraram que fosfocolina e fosfoetanolamina podem ser hidrolisados por uma fosfatase ácida expressa em condrócitos (Houston et al., 2004), sugerindo que a geração de $P_{i}$ em células envolvidas no processo de biomineralização pode estar acoplada à degradação de fosfolipídios.

Os fosfolipídios ácidos que tem grande afinidade por cálcio, principalmente a fosfatidilserina, são geralmente encontrados nas membranas das vesículas extracelulares, na região de mineralização (Wuthier, 1975, 1982; Boskey, 1981; Boyan et al., 1989; Boskey e Dick, 1991; Boskey et al., 1996; Wu et al., 1997, 2002; Damek-Poprawa et al., 2006) e são capazes de promover a formação de hidroxiapatita in vitro, mesmo na ausência de fosfatase alcalina (Vogel, 1986; Eanes e Hailer, 1987; Heywood e Eanes, 1987). Além disso, eles podem atuar na 
regulação da biomineralização biológica regulando o transporte de íons cálcio através da organização estrutural da membrana e também promovendo a nucleação de hidroxiapatita pela interação com íons cálcio e estabilização de associações de fosfato de cálcio amorfo (Boskey, 1981; Wuthier et al., 1985; Boyan et al., 1989; Kirsch et al., 1997; Wu et al., 1997; Damek-Poprawa et al., 2006).

A composição lipídica das vesículas da matriz parece ser controlada pela vitamina $\mathrm{D}$ e/ou pela presença de colesterol. Provavelmente, mudanças na atividade da fosfatase alcalina podem ser resultantes de alterações na composição lipídica da membrana celular. Assim, alterações que podem ocorrer nas funções das vesículas podem representar um mecanismo de regulação da formação do mineral (Brasitus et al., 1988; Boyan et al., 1989). Um problema que tem dificultado os estudos in vitro é que a reação de indução de deposição de minerais por complexos lipídio - cálcio fosfato é lenta, necessitando freqüentemente de vários dias para a obtenção significativa de mineral. Além disso, os níveis de íons minerais e/ou pH nas soluções metaestáveis de fosfato de cálcio geralmente usados nestes estudos são baixos. Em síntese, qualquer conclusão acerca da importância dos complexos de lipídios na mineralização mediada por vesículas extracelulares necessita de estudos mais aprofundados sobre a cinética da mineralização induzida por tais complexos, especialmente num sistema onde o $\mathrm{pH}$ e os níveis de eletrólitos sejam semelhantes àqueles encontrados no interior da vesícula ou no fluido extracelular nativo (Ciancaglini et al., 2006; Millán, 2006).

Estudos efetuados para se determinar os tipos de lipídios, de eletrólitos e, principalmente, as enzimas presentes nas vesículas extracelulares, têm revelado que a fosfatase alcalina não é a única enzima importante para o processo de biomineralização biológica presente na membrana, mas apresenta um papel crucial (Hsu, 1994; Anderson, 1995; Pizauro et al., 1998; Hamade et al., 2003). Dentre elas, tem sido demonstrada a presença de elevados níveis de pirofosfatase, de adenosina-5'-trifosfatase (Pizauro et al., 1998; Hsu e Anderson, 1995), de PHOSPHO1 (Houston et al., 1999, 2004; Stewart et al., 2006; Roberts et al., 2007) e da ectoenzima NPP1 (Johnson et al., 2000; Gijsbers et al., 2001; Hessle et al., 2002). Segundo Johnson e colaboradores (1999, 2000) e Gijsbers e colaboradores (2001), a NPP1 utiliza o ATP presente no fluido extracelular da cartilagem para gerar o substrato da ectofosfatase alcalina, o pirofosfato inorgânico ( $\left.P P_{i}\right)$. Já a fosfatase PHOSPHO1 está envolvida na geração de $\mathrm{P}_{\mathrm{i}}$ acoplada à degradação de 
fosfolipídios, através da hidrólise de fosfocolina e fosfoetanolamina (Roberts et al., 2004), sugerindo um novo caminho para a regulação da concentração de fosfato necessária para a formação do cristal de hidroxiapatita. Há evidências de que a ação conjunta de fosfatase alcalina e NPP1 é capaz de regular os níveis de $\mathrm{PP}_{\mathrm{i}}$ no fluído extracelular, promovendo assim um controle coordenado do processo de mineralização (Harmey et al., 2004). Uma nova fosfoglicoproteína da matrix extracelular (Mepe), expressa em osteócitos e osteoblastos, também parece atuar como um regulador negativo do processo de mineralização, inibindo a formação óssea, embora sua função exata durante este processo não seja conhecida (Petersen et al., 2000; Rowe et al., 2000; Argiro et al., 2001; Gowen et al., 2003).

Além disso, já foi demonstrado que a fosfatase alcalina também pode hidrolisar o ATP, liberando o fosfato inorgânico. A enzima é regulada alostericamente pelo ATP (Pizauro et al., 1993) e inibida competitivamente pelo produto da reação, o fosfato inorgânico (Pizauro et al., 1987), sugerindo que os níveis relativos de $\mathrm{PP}_{\mathrm{i}}$, um inibidor da biomineralização, e de $\mathrm{P}_{\mathrm{i}}$, um inibidor da fosfatase alcalina, presentes no fluído extracelular da matriz, também desempenham um papel importante na regulação do processo de mineralização biológica. Esta hipótese encontra suporte na recente demonstração de que o nível de fosfato inorgânico, derivado da hidrólise do $\mathrm{PP}_{\mathrm{i}}$ pela fosfatase alcalina, atua como um sinal da indução da expressão da glicoproteína fosforilada osteopontina em osteoblastos (Beck et al., 2000). Recentemente foi demonstrado que a fosfatase alcalina pode também contribuir para a geração de $\mathrm{PP}_{\mathrm{i}}$ através de sua atividade de fosfodiesterase, hidrolisando ATP (Zhang et al., 2005), contradizendo evidências de que a enzima teria uma função antagonista à da glicoproteína-1 no processo de mineralização (Hessle et al., 2002), embora uma das principais funções já descrita da fosfatase alcalina seja a remoção de $\mathrm{PP}_{\mathrm{i}}$ do ambiente de mineralização através de sua atividade de fosfomonohidrolase (Rezende et al., 1998). Mas recentemente Nakano e colaboradores (2007) demonstraram que a fosfatase alcalina não é a principal enzima responsável pela hidrólise de ATP e consequente mineralização de culturas de células osteoblásticas, mas que outras enzimas, tais como ATPase 1 transportadora de cálcio da membrana plasmática (PMCA1) e transglutaminase 2 (TG2), podem agir como fosfatases hidrolisando ATP, propondo uma ação sinérgica das três enzimas na regulação do processo de mineralização da matriz óssea.

O pirofosfato inorgânico $\left(\mathrm{PP}_{\mathrm{i}}\right)$ participa da regulação de vários eventos 
intracelulares e extracelulares de uma grande variedade de tecidos, sugerindo que a regulação da sua síntese, degradação e transporte ocorre por meio de mecanismos altamente especializados. O papel fisiológico do pirofosfato extracelular tem sido muito estudado nos últimos anos, principalmente em relação ao processo de mineralização biológica. A compreensão dos eventos que participam da síntese e do metabolismo do pirofosfato no tecido ósseo pode contribuir para elucidar sua participação no processo de biomineralização. O pirofosfato é um potente inibidor da mineralização biológica, da formação de "pedra" nos rins e em outros fluidos extracelulares (Wuthier et al., 1972; Fleisch e Russell, 1972; Krug et al., 1993; Anderson et al., 1997; Galperin et al., 1998; Okawa et al., 1998; Johnson et al., 1999, 2000; Rutsch et al., 2001; Terkeltaub, 2001; Hessle et al., 2002; Addison et al., 2007). Além disso, tem sido verificado que o pirofosfato inibe a capacidade dos condrócitos de depositar minerais diretamente (especificamente cristais de hidroxiapatita e de fosfato de cálcio básico) na matriz pericelular do tecido ósseo (Poole et al., 1989; Johnson et al., 1999, 2000). Especula-se, ainda, que a remoção e/ou a degradação do pirofosfato é necessária para destruir seu efeito inibitório da mineralização biológica mediada pelas vesículas extracelulares (Meyer, 1984; Anderson, 1995; Anderson et al., 1997; Leone et al., 1997a; Rezende et al., 1998; Hessle et al., 2002; Garimella et al., 2006; Addison et al., 2007). Por outro lado, a propagação dos cristais de hidroxiapatita fora das vesículas extracelulares também é inibida pelo $\mathrm{PP}_{\mathrm{i}}$ (Anderson, 1995, 2003). Assim, acredita-se que a fosfatase alcalina apresenta um papel fundamental no processo de calcificação atuando na remoção do $\mathrm{PP}_{\mathrm{i}}$ através de sua hidrólise, já que foi demonstrada acentuada hipomineralização em camundongos nocauteados para o gene de fosfatase (Anderson et al., 2004).

Uma deficiência na isoenzima TNAP causa um erro de metabolismo congênito conhecido como hipofosfatasia e o estudo dessa doença tem fornecido grandes evidências da importância da TNAP para a mineralização óssea. TNAP é a única isoenzima tecido não-restrita de uma família de quatro genes AP humanos homólogos (EC. 3.1.3.1.) (Millán, 2006). Expressa como uma ectoenzima ancorada via uma âncora de fosfatidilinositol glicana, TNAP tem demonstrado desempenhar uma função fisiológica essencial durante a mineralização da matriz óssea. Especificamente, mineralização óssea defeituosa (osteomalácia) ocorre com a deficiência de TNAP (hipofosfatasia) (Whyte, 1995). A severidade da hipofosfatasia é variável e modulada pela natureza da mutação da TNAP (Henthorn et al., 1992; 
Fukushi et al., 1998; Shibata et al., 1998; Zurutuza et al., 1999). Bioquimicamente, a hipofosfatasia é diagnosticada por um baixo nível de TNAP no soro, bem como pelo acúmulo dos fosfocompostos pirofosfato inorgânico ( $\left(P_{\mathrm{i}}\right)$, piridoxal-5'-fosfato (PLP) e fosfoetanolamina (PEA) (Whyte, 1995; Millán, 2006).

No osso, a TNAP está localizada na superfície celular de osteoblastos e condrócitos, incluindo as membranas de suas vesículas da matriz desprendidas (Ali et al., 1970; Bernard, 1978). De fato, por um mecanismo desconhecido, MVs são altamente enriquecidas em TNAP quando comparadas com células inteiras e com a membrana plasmática (Morris et al., 1992). Tem sido proposto que a função da TNAP na matriz óssea é gerar o fosfato inorgânico necessário para a cristalização da hidroxiapatita (Robison, 1923; Majeska e Wuthier, 1975; Fallon et al., 1980). É conhecido há algum tempo que fosfatases alcalinas, tanto de origem bacteriana quanto de origem mamífera, possuem atividade fosfodiesterase (Moss e Walli, 1969; Rezende et al., 1994; O'Brien e Herschlag, 2001) e são capazes de produzir PP $\mathrm{i}_{\mathrm{i}}$ partir de ATP. Além disso, TNAP também é capaz de defosforilar ATP, ADP e AMP, que são substratos e biprodutos da função da NPP1 (Picher e Boucher, 2001; Picher et al., 2003). No entanto, TNAP também tem sido considerada hidrolisar o inibidor da mineralização $\mathrm{PP}_{\mathrm{i}}$ (Meyer, 1984) para facilitar o crescimento e a precipitação do mineral (Moss et al., 1967; Rezende et al., 1994; Anderson et al., 2005). Estudos de microscopia eletrônica revelaram que vesículas da matriz deficientes em TNAP, tanto em humanos quanto em ratos, contêm cristais de apatita, mas que a propagação extravesicular do cristal é retardada (Anderson et al., 1997, 2004). Este atraso no crescimento poderia ser devido tanto à falta da função de pirofosfatase da TNAP ou à falta da geração de fosfato inorgânico. Recentes estudos têm demonstrado que a função da TNAP no tecido ósseo consiste em hidrolisar PP $_{\mathrm{i}}$ para manter uma concentração adequada deste inibidor da mineralização, de modo a assegurar uma mineralização óssea normal (Anderson et al., 2004; Millán, 2006).

$\mathrm{O} \mathrm{PP}_{\mathrm{i}}$ é primariamente gerado pelos membros da família de isoenzimas nucleotídeo pirofosfatase/fosfodiesterase (NPP). A glicoproteína-1 (PC-1, mais corretamente denominada NPP1) da membrana celular plasmática é ligada à membrana plasmática, enquanto a autotaxina (NPP2) é secretada e a B10 (NPP3) é abundante nos espaços intracelulares (Terkeltaub, 2001). Estas três isoenzimas são expressas em uma grande variedade de tecidos, incluindo osso e cartilagem (Huang et al., 1994), e todas têm a habilidade comum de hidrolisar diésteres de ácido 
fosfórico em fosfomonoésteres, primariamente ATP em AMP e/ou ADP em adenosina. As NPPs estão envolvidas em vários processos, incluindo mineralização óssea, sinalização por insulina e por nucleotídeos, e diferenciação e motilidade de células (Bollen et al., 2000). No entanto, as NPPs são conhecidas primariamente como fornecedoras de $\mathrm{PP}_{\mathrm{i}}$ intra e extracelular (Meyer, 1984). Similarmente à expressão esquelética de TNAP, a NPP1 é altamente abundante nas superfícies de osteoblastos e condrócitos, bem como nas membranas de suas vesículas da matriz (Hashimoto et al., 1998; Johnson et al., 1999). A NPP1 apresenta a função de inibir a precipitação de hidroxiapatita por sua propriedade de geração de $\mathrm{PP}_{\mathrm{i}}$.

Assim como a NPP1, a proteína anquilose (ANK) tem uma função durante o processo de mineralização, contribuindo para o fornecimento de $\mathrm{PP}_{\mathrm{i}}$ extracelular. No entanto, ao contrário da NPP1, ANK parece funcionar como uma proteína transmembrana de canal de $\mathrm{PP}_{\mathrm{i}}$, permitindo às moléculas de $\mathrm{PP}_{\mathrm{i}}$ passarem através da membrana plasmática, do citoplasma para fora da célula (Ho et al., 2000; Nürnberg et al., 2001). A proteína ANK é detectável em muitos tecidos, embora sua expressão seja particularmente forte na cartilagem de juntas (Ho et al., 2000). As superfícies celulares de osteoblastos e condrócitos parecem ser abundantes em proteína ANK (Wang et al., 2005), mas esta não está presente nas membranas das vesículas da matriz, ao contrário do que ocorre com as proteínas NPP1 e TNAP.

A produção por osteoblastos de um inibidor da mineralização da matriz extracelular, como $\mathrm{PP}_{\mathrm{i}}$, sugere um modelo onde a remoção de um inibidor, ao invés da síntese de um indutor da mineralização, explicaria por que a mineralização da matriz extracelular ocorre no osso (Murshed et al., 2005). Consistente com este modelo, recentemente foi demonstrado que a remoção de $\mathrm{PP}_{\mathrm{i}}$, via ação da TNAP, e a presença de um suporte rico em colágeno fibrilar, são duas condições necessárias para induzir a mineralização de osso ou de qualquer matriz extracelular, indicando também que a razão $\mathrm{P}_{\mathrm{i}} / \mathrm{PP}_{\mathrm{i}}$ é de fundamental importância para a mineralização óssea da matriz extracelular (Millán, 2006). Assim, na matriz extracelular óssea, enquanto a concentração extracelular de $P_{i}$ é bastante constante, a degradação enzimática de $\mathrm{PP}_{\mathrm{i}}$ pela TNAP controla a razão $\mathrm{P}_{\mathrm{i}} / \mathrm{PP}_{\mathrm{i}}$ para favorecer a cristalização de hidroxiapatita fora das vesículas da matriz junto com fibrilas de colágeno (Murshed et al., 2005). Mas como a TNAP se localiza na superfície externa das membranas das vesículas da matriz, não há nenhuma hidrólise de $\mathrm{PP}_{\mathrm{i}}$ mediada por TNAP dentro das vesículas da matriz. Portanto, é provável que uma outra enzima 
seja responsável por clivar $\mathrm{PP}_{\mathrm{i}}$ ou elevar a concentração de $\mathrm{P}_{\mathrm{i}}$ intravesicular, de forma a alcançar uma razão $\mathrm{P}_{\mathrm{i}} / \mathrm{PP}_{\mathrm{i}}$ que conduza à cristalização. Talvez a proteína PHOSPHO1, uma fosfatase solúvel (Stewart et al., 2003; Houston et al., 2004), que apresenta especificidade para fosfatidiletanolamina, fosfatidilcolina e fosfatidilserina (Roberts et al., 2004), tenha a importante função de aumentar a razão $\mathrm{P}_{\mathrm{i}} / \mathrm{PP}_{\mathrm{i}}$ dentro das vesículas da matriz e assim controlar a primeira etapa de início de deposição de hidroxiapatita mediada por vesículas da matriz.

Recentemente, Ciancaglini e colaboradores (2006) demonstraram que as propriedades catalíticas da fosfatase alcalina de placas ósseas variam dependendo do microambiente onde a enzima se encontra. Assim, diferentes formas da enzima (ligada à membrana, solubilizada com detergente ou tratada com PIPLC) apresentaram diferentes especificidades para os diversos substratos estudados, mostrando que a cinética da enzima é grandemente afetada pela presença tanto da âncora de fosfatidilinositol quanto de outros componentes da membrana celular.

\subsection{Solubilização e reconstituição da fosfatase alcalina}

Estudos de proteínas de membrana em seu microambiente nativo são de difícil interpretação devido à complexidade da membrana nativa e interferências de outros constituintes da membrana (Gennis, 1989; Yeagle, 1993; Wu et al., 2002). Assim, uma técnica utilizada para o seu estudo é a retirada da proteína da membrana, através do uso de um detergente, que deve manter a proteína em um estado funcional e enovelado (Privé, 2007).

Nos últimos trinta anos, a utilização de detergentes tem alcançado grande sucesso na solubilização de proteínas de membranas, podendo-se encontrar excelentes revisões sobre detergentes comumente utilizados, incluindo suas propriedades físicas (Marie et al., 2000).

Uma solubilização efetiva de proteínas de membrana envolve tanto a seleção do detergente adequado, bem como a determinação de condições apropriadas para a solubilização. Os efeitos do $\mathrm{pH}$ e da temperatura também afetam marcadamente este processo. A compatibilidade do detergente com métodos preparativos específicos ou analíticos deve ser considerada, bem como a possível remoção do detergente no final da purificação (Santos e Ciancaglini, 2000).

A maioria dos detergentes, tanto iônicos (catiônicos ou aniônicos) como nãoiônicos (neutros), são substâncias anfifílicas solúveis. Quando o detergente é 
adicionado à água, ocorre a formação de uma monocamada na interface ar-água que está em equilíbrio com os monômeros do detergente, ou com os monômeros e os seus cristais líquidos na fase aquosa. Quando a concentração dos monômeros de detergente alcança um nível crítico, e a temperatura é favorável, estes se associam formando micelas, onde a parte hidrofóbica das moléculas está voltada para o interior da micela, e a parte hidrofílica está direcionada para fora, na fase aquosa (Koepsell, 1986). A concentração de detergente necessária para a formação de micelas é denominada Concentração Micelar Crítica (CMC). A CMC é característica para cada detergente, e dependente da temperatura, força iônica, presença de álcoois e pH do meio (Silvius, 1992). A formação das micelas requer também uma temperatura crítica, ou seja, Temperatura Micelar Crítica (CMT), que é dependente da natureza do detergente (Carey e Small, 1972).

De uma maneira geral, os detergentes não iônicos são frequentemente empregados na solubilização de membranas lipoprotéicas, devido a três importantes fatores: (i) a sua eficiência no rompimento das interações lipídio-lipídio e lipídioproteína; (ii) a sua ineficiência no rompimento de interações proteína-proteína e (iii) por serem menos desnaturantes que os detergentes iônicos (Tzagaloff e Penefsky, 1971; Helenius e Simons, 1975; Helenius et al., 1979; Koepsell, 1986).

Outros detergentes empregados nos estudos de solubilização de proteínas de membrana são os zwiteriônicos, que aparentemente são mais efetivos na solubilização de proteínas e não provocam a sua desnaturação, ao contrário dos outros tipos de detergentes (Hjelmeland, 1980).

Dentre os métodos empregados para a remoção de detergentes de proteínas solubilizadas, destacam-se a diálise, filtração em gel, centrifugação em gradiente de sacarose, uso de solventes orgânicos, bem como o emprego de resinas hidrofóbicas (Holloway, 1973; Kagawa et al., 1973; Warren et al., 1974; Horikawa e Ocawara, 1979; Horigome e Sugano, 1983; Pizauro et al., 1987; Levy et al., 1992; Angrand et al., 1997; Nosjean e Roux, 1999; Camolezi et al., 2002; Morandat et al., 2002, 2003; Ronzon et al., 2004). A vantagem do emprego de resinas do tipo biobeads consiste em ser um método rápido, onde a amostra não sofre diluições (Horigome e Sugano, 1983).

Uma ferramenta poderosa para a elucidação de aspectos funcionais e estruturais de proteínas associadas à membrana é a sua incorporação em vesículas constituídas de fosfolipídios (lipossomos). A habilidade dessas vesículas para 
mimetizar a organização e algumas funções de membranas celulares faz destas estruturas um modelo experimental conveniente e vantajoso para o estudo das propriedades de sistemas biológicos de membranas organizados (Camolezi et al., 2002; Rigos et al., 2006; Santos et al., 2006). Além disso, o uso de sistemas reconstituídos tem se mostrado uma poderosa ferramenta para o controle preciso da composição e propriedades biofísicas da membrana, possibilitando avaliar seu efeito sobre a atividade enzimática de proteínas de interesse (Sharom e Lehto, 2002).

Lipossomos são espontaneamente formados quando fosfolipídios são dispostos em meio aquoso, e esta formação deve-se à interação hidrofílica da cabeça polar dos grupos fosfato com a água, resultando na formação de sistemas com muitas bicamadas (multilamelares). Esta organização é dirigida pela entropia das moléculas de água e pela interação entre as cadeias hidrofóbicas dos lipídios (constituídas por ácidos graxos). Estes sistemas multilamelares podem ser sonicados ou forçados a passar por poros de dimensões nanométricas (extrusão) para formar sistemas unilamelares (com uma única bicamada concêntrica), muito similares às membranas naturais. O processo de sonicação, bem como o processo de extrusão, fornecem a energia necessária para quebrar as diferentes lamelas e reorganizar as bicamadas em tamanhos uniformes e controlados.

Lipossomos foram descritos pela primeira vez por Bangham na década de 60 como sendo vesículas lipídicas constituídas por uma ou mais bicamadas lipídicas, e desde então vêm sendo utilizados como modelos de biomembranas (Bangham et al., 1965; Rongen et al., 1997; Camolezi et al., 2002; lerardi et al., 2002; de Lima Santos et al., 2005). Estas estruturas unilamelares ou multilamelares têm sido úteis para o estudo de receptores de membrana, proteínas de canal e enzimas associadas à membrana (New, 1990), e mais recentemente, têm sido utilizadas como agentes carreadores para drug delivery (Vemuri e Rhodes, 1995), bem como potenciais imunoadjuvantes (Gregoriadis, 1990; Santos et al., 2006). Além disso, existem muitas vantagens no uso de lipossomos: são biodegradáveis e atóxicos e podem ser facilmente preparados com composições lipídicas variáveis de modo a se obter a formulação desejada.

A preparação de lipossomos com uma grande variedade de lipídios naturais e sintéticos pode ser obtida por diferentes métodos, como dispersão mecânica, sonicação, extrusão, dispersão em solvente, co-solubilização com detergentes, evaporação de fase reversa, entre outras (New, 1990; Arien et al., 1994; Prasad, 
1996; Arien e Dupuy, 1997). Dentre estes diferentes métodos de obtenção, a sonicação, utilizando microponta de titânio, se destaca pelo fato de serem obtidas vesículas unilamelares pequenas (ULV), com tamanho relativamente uniforme (50$200 \mathrm{~nm}$ ) e possibilitando ainda a preparação de pequenas quantidades (New, 1990; Fleury et al., 1995; Prasad, 1996; Arien e Dupuy, 1997). A obtenção de lipossomos por sonicação pode ser obtida com diferentes fosfolipídios, misturas de fosfolipídios ou seus derivados, e empregando-se diferentes temperaturas. A escolha de um determinado tipo de fosfolipídio e sua concentração é de primordial importância tanto para a reprodutibilidade de experimentos bem como para a estabilidade do sistema vesicular formado (New, 1990; Prasad, 1996).

Alguns estudos encontrados na literatura relatam que a incorporação de uma proteína que apresenta uma âncora de fosfatidilinositol pode ser obtida por simples incubação da proteína com uma suspensão de lipossomos (Schroeder et al., 1994; Schreier et al., 1994), ou por vários ciclos de congelamento e descongelamento da proteína em uma suspensão de fosfolipídios (Schroeder et al., 1994), ou ainda pela reconstituição de proteolipossomos por sonicação e diálise na presença de detergente (Fini et al., 1994), também empregado para proteínas transmembrana (Rigaud et al., 1995). Especificamente em relação à fosfatase alcalina, vários estudos vêm sendo realizados demonstrando sua capacidade de incorporação em lipossomos de diferentes composições lipídicas (Angrand et al., 1997; Nosjean e Roux, 1999; Camolezi et al., 2002; Morandat et al., 2002, 2003; Ronzon et al., 2004).

Para se compreender as funções detalhadas da fosfatase alcalina, bem como outras enzimas importantes das vesículas da matriz na iniciação da biomineralização, deve-se ter em mente o microambiente no qual estas enzimas funcionam, os quais podem ter um profundo efeito sobre suas propriedades biológicas. Dados recentes (Ciancaglini et al., 2006) sugerem que a localização da fosfatase alcalina na membrana das vesículas da matriz pode determinar a seletividade de substrato neste micro compartimento. Estes dados indicam que ensaios com a fosfatase alcalina associada a vesículas da matriz ou a sistemas lipossomais podem ser biologicamente mais importantes do que ensaios feitos com preparações de enzimas solubilizadas. Além disso, estudos recentes utilizando lipossomos de DPPC como compartimentos vesiculares para isolar íons demonstraram ser esta uma boa estratégia para aumentar a deposição de fosfato de cálcio em substratos teciduais (Murphy e Messersmith, 2000). 


\subsection{Células ghost}

Os eritrócitos são as células vermelhas do sangue, possuem o formato de um disco bicôncavo e não possuem núcleo nem organelas. Estas células sofrem maturação a partir de células precursoras na medula óssea e têm uma vida curta, de aproximadamente 120 dias. São células especializadas no transporte de oxigênio e gás carbônico, preenchidas com hemoglobina (pigmento vermelho), e têm também como função a manutenção do pH sanguíneo. Seu formato bicôncavo proporciona uma grande razão superfície/volume, adequada para a distribuição de oxigênio e melhor flexibilidade em capilares estreitos (Alberts et al., 1994; Hillman e Finch, 1996).

As células vermelhas comportam-se como osmômetros, inchando e encolhendo com a variação na pressão osmótica do líquido em que estão envolvidas. Em soluções hipotônicas, o eritrócito intumesce e ocorre a ruptura da membrana ou hemólise, que pode também ser produzida em soluções isotônicas pela ação de agentes surfactantes. Como estas células apresentam, praticamente, todos os seus componentes em solução, com a hemólise resta apenas a parte insolúvel, que é constituída pela membrana plasmática (Smith et al., 1983).

Como os eritrócitos não possuem membranas internas (organelas), o estudo de sua membrana plasmática é fácil de ser realizado, pois esta pode ser isolada sem contaminação de outras membranas (Alberts et al., 1994). O estudo destas membranas é feito pela preparação de espectros de eritrócitos vazios ou células ghost resseladas, que são, resumidamente, eritrócitos rompidos, lavados e resselados, formando vesículas que englobam o líquido em que estão inseridas no momento da resselagem (Steck et al., 1970; Fairbanks et al., 1971; Smith et al., 1983; Alberts et al., 1994).

A partir destas vesículas foram estudadas as proteínas e lipídios de membrana, tanto da face interna como da face externa das membranas plasmáticas das células. Além disso, foi demonstrado que algumas proteínas de membrana estendem-se através da bicamada lipídica, e que a composição lipídica das duas metades da bicamada é diferente. Estes resultados foram posteriormente estendidos para as membranas de células nucleadas (Smith et al., 1983; Bratton, 1994; Alberts et al., 1994).

Sabendo-se que a membrana de células ghost é um típico sistema de membrana assimétrico, com maior distribuição em aminofosfolipídios na 
monocamada interna, Di e colaboradores (2006) utilizaram células ghost obtidas de eritrócitos de rato para investigar o efeito da distribuição assimétrica de aminofosfolipídios na suscetibilidade da membrana à peroxidação induzida por íons ferro. Foi observado significativamente mais aminofosfolipídios e maior peroxidação lipídica nas vesículas inside-out (IOVs) do que nas vesículas right-side-out (ROVs), bem como uma maior agregação de proteínas, sugerindo que a distribuição assimétrica de fosfolipídios em biomembranas afeta sua suscetibilidade oxidativa de diferentes modos, e que um maior conteúdo em aminofosfolipídios na superfície externa da membrana aumenta sua suscetibilidade ao estresse oxidativo.

No eritrócito, a membrana plasmática é constituída de $49 \%$ de proteínas, $44 \%$ de lipídios e $7 \%$ de carboidratos. Do total de lipídios, $25 \%$ é colesterol, $60 \%$ são fosfoglicerídeos, 5 a $10 \%$ são glicolipídios e existem pequenas quantidades de ésteres de colesterol, ácidos graxos livres, sulfatídios e triacilgliceróis (Fairbanks et al., 1971; Smith et al., 1983).

Estudando-se a membrana do eritrócito humano por eletroforese em gel de poliacrilamida contendo SDS, foram detectadas aproximadamente 15 bandas protéicas principais, com massas moleculares variando de 15 a 250 kDa. Entre elas estão a espectrina, a actina, a anquirina, a proteína banda 3, a proteína banda 4.1 e a glicoforina (Steck et al., 1970; Fairbanks et al., 1971; Smith et al., 1983; Alberts et al., 1994). As mesmas proteínas estão presentes na membrana plasmática de quase todos os eritrócitos de vertebrados. A espectrina e a actina fazem parte do citoesqueleto, enquanto a proteína banda 3 e a glicoforina são proteínas integrais da membrana, que possuem em suas cadeias polipeptídicas regiões hidrofóbicas que se ligam fortemente aos fosfolipídios da bicamada, fixando as proteínas à membrana plasmática (Smith et al., 1983).

O citoesqueleto das células vermelhas do sangue é bem desenvolvido e bioquimicamente melhor caracterizado que o de outras células. Takeuchi e colaboradores (1998) demonstraram que o esqueleto da membrana é um arranjo de filamentos denso, complexo e tridimensional. Os maiores constituintes deste citoesqueleto são dímeros de espectrina, unidades flexíveis de $100 \mathrm{~nm}$ de comprimento, que são importantes determinantes do formato do eritrócito e da estabilidade da membrana. Estes dímeros associam-se formando tetrâmeros, que são unidos por complexos juntacionais, em um arranjo bidimensional. Estes complexos juntacionais são compostos por pequenos filamentos de actina, banda 
4.1, glicoforina C e várias outras proteínas menores (Dubreuil e Grushko, 1998).

Experimentos demonstraram que a ligação da malha de espectrina à membrana plasmática depende, principalmente, de uma grande proteína intracelular de ligação chamada anquirina, a qual se liga tanto à espectrina quanto ao domínio citoplasmático da proteína banda 3 . Além de ligar a malha de espectrina à membrana plasmática, esta ligação também reduz a mobilidade da proteína banda 3 na bicamada lipídica. A ligação do citoesqueleto à membrana plasmática também é feita por mecanismos que dependem da proteína banda 4.1. Esta se liga à espectrina e à actina, e também aos domínios citoplasmáticos da proteína banda 3 e da glicoforina (Alberts et al., 1994).

A proteína banda 3 , cujo nome deriva de sua posição em relação às outras proteínas após eletroforese em gel de poliacrilamida contendo SDS, desempenha um papel estrutural na fixação do citoesqueleto à membrana e é catalisadora do transporte acoplado de ânions. É uma proteína essencial para que o eritrócito transporte gás carbônico dos tecidos para os pulmões, possibilitando ao $\mathrm{CO}_{2}$, que é pouco solúvel em água, atravessar a membrana em um processo de troca com o cloreto $\left(\mathrm{Cl}^{-}\right)$. No interior do eritrócito, $\mathrm{O} \mathrm{CO}_{2}$ é transformado em bicarbonato pela anidrase carbônica (que está associada à proteína banda 3), que catalisa esta reação, tornando o bicarbonato solúvel que pode, agora, ser transportado pelo sangue (Smith et al., 1983; Alberts et al., 1994). A proteína banda 3 é constituída por dois domínios estruturais e funcionais: o domínio citoplasmático, de 43 kDa, que está envolvido nas interações protéicas com proteínas estruturais e enzimas metabólicas, e o domínio da membrana, de $55 \mathrm{kDa}$, que é responsável pela função transportadora de íons desta proteína (Vince e Reithmeier, 1998).

A glicoforina é uma proteína altamente glicosilada (cerca de 60\% em massa) que contém a maior parte de sua massa na superfície externa da membrana e parece desempenhar apenas um papel estrutural, embora seja responsável pelos determinantes de grupos sanguíneos (Smith et al., 1983; Alberts et al., 1994). A membrana plasmática do eritrócito também possui proteínas que apresentam atividade ATPase, como a bomba de sódio e potássio (Na,K-ATPase) e a bomba de cálcio (Ca-ATPase), relatadas por Smith e colaboradores (1983).

Atualmente, as células ghost resseladas vêm sendo utilizadas por diferentes pesquisadores com novos enfoques. Coakley (1987) utilizou as células ghost para observar os efeitos da hipertermia no citoesqueleto e na morfologia da célula. 
Segundo Coakley, as células ghost resseladas possuem cinco transições termais entre 50 e $75^{\circ} \mathrm{C}$. Há uma fragmentação espontânea das membranas a $50^{\circ} \mathrm{C}$, que está relacionada com a desnaturação da proteína espectrina do citoesqueleto. A hemólise ocorre a $65^{\circ} \mathrm{C}$ e a microvesiculação é observada a $70^{\circ} \mathrm{C}$.

Iwaki-Egawa e Ihler (1997) utilizaram estas vesículas para comparar a habilidade de incorporação das proteínas de Bartonella bacilliformis e $B$. henselae às membranas. Jackson e colaboradores (1996) investigaram a interação de microcristais de urato monossódico monoidratado (MSUM) com eritrócitos e o mecanismo de indução à hemólise.

A partir de células ghost, Lejeune e colaboradores (1997) desenvolveram um novo sistema vesicular que também pode ser utilizado como carregador de drogas e moléculas biológicas, os nanoeritrossomos. Estas pequenas vesículas de $100 \mathrm{~nm}$ de diâmetro foram construídas a partir da extrusão de células ghost previamente preparadas.

Arsov e colaboradores (2004) analisaram a influência da composição lipídica lateral da membrana de ghosts de eritrócitos bovinos na atividade da enzima acetilcolinesterase, associada à membrana através de âncora GPI, e observaram uma estreita correlação entre os parâmetros de ordem encontrados para os domínios mais ordenados, a proporção desses domínios na membrana e a atividade da enzima, sugerindo que as moléculas protéicas encontram-se ancoradas em regiões específicas da membrana, enriquecidas em colesterol. Além disso, a membrana estabiliza a conformação da proteína ancorada quando comparada com a enzima isolada. Assim, os resultados observados fornecem evidências de que a função de proteínas que possuem âncora GPI pode ser modulada pelas propriedades da bicamada lipídica.

Recentemente, Yamaguchi e colaboradores (2007) estudaram os efeitos de diferentes temperaturas de incubação $\left(0-37^{\circ} \mathrm{C}\right)$ na estrutura de membranas de ghost sob condições hipotônicas, e observaram, em temperaturas superiores a $30^{\circ} \mathrm{C}$, redução do volume das ghost, liberação da espectrina da membrana e diminuição das interações entre a proteína banda 3 e o citoesqueleto.

Kriebardis e colaboradores (2007) avaliaram o conteúdo em hemoglobina e as alterações oxidativas que ocorrem no citoesqueleto de eritrócitos em função de seu tempo de armazenamento. Foram observados aumento na hemoglobina desnaturada ligada ao citoesqueleto e à membrana, ligação cruzada entre a 
espectrina e a hemoglobina e elevado índice oxidativo dos componentes isolados do citoesqueleto, os quais foram todos agravados com o armazenamento prolongado das células, levando a um progressivo acúmulo de monômeros e multímeros de hemoglobina, bem como agregados de alta massa molecular correspondentes aos componentes do citoesqueleto. Estes dados confirmam a hipótese da ocorrência de danos oxidativos nas proteínas de membrana de células armazenadas, com ênfase nos componentes do citoesqueleto, sugerindo o possível uso de aditivos antioxidantes para o armazenamento das células, de modo a impedir o envelhecimento precoce das mesmas.

Os eritrócitos são sistemas atrativos devido também à sua habilidade potencial para a entrega de proteínas e peptídios terapêuticos. Estas células têm sido utilizadas para se estudar o transporte de enzimas destinadas à correção de alterações metabólicas, como L-asparaginase, álcool desidrogenase (ADH) e aldeído desidrogenase (AIDH), entre outras. Eritrócitos também têm sido usados com sucesso como carreadores de peptídeos anti-HIV, como o AZT, análogos de nucleosídeos, oligonucleotídeos antisense, peptídeos antineoplásicos, interleucina 3 e até mesmo genes, dirigindo-os seletivamente para o seu sítio de ação (Magnani et al., 2002; Millán et al., 2004).

Empregando-se os sistemas vesiculares de lipossomos ou de células ghost, cuja metodologia de obtenção foi padronizada em nosso laboratório (Camolezi et al., 2002; lerardi et al., 2002), o envolvimento da enzima e dos lipídios durante o processo de mineralização torna-se mais fácil de ser estudado, pois estes sistemas podem mimetizar a função das vesículas tanto em sistemas in vitro bem como in vivo. Recentemente, Michel e colaboradores (2004) demonstraram a capacidade de um sistema constituído de lipossomos e fosfatase alcalina depositar cristais de fosfato de cálcio no interior das vesículas, na presença de íons cálcio, espermina e PNFF no meio reacional. Blandford e colaboradores (2003) também propuseram um modelo vesicular que mimetiza as vesículas da matriz, sendo capaz de induzir a formação mineral, com diâmetro, composição lipídica e níveis de $P_{i}$ similares aos encontrados em vesículas originais. 


\section{Objetivos}

O objetivo deste projeto foi padronizar uma metodologia de obtenção da fosfatase alcalina a partir de culturas de células osteoblásticas provenientes de medula de rato. Apesar de culturas de osteoblastos já serem utilizadas por vários autores com outros enfoques, ainda não existe uma metodologia descrita para a obtenção da enzima a partir destas culturas, apresentando a estrutura protéica intacta com a âncora de fosfatidilinositol necessária para a correta reconstituição em sistemas vesiculares, tornando esta parte do trabalho também inovadora.

Além disso, foi padronizada a reconstituição da enzima em células ghost resseladas e em lipossomos de diferentes composições lipídicas, sendo obtida a purificação parcial da enzima através de sua incorporação em lipossomos de DPPC. Todos os sistemas vesiculares obtidos foram caracterizados cineticamente através de estudos de hidrólise de PNFF, ATP e PP pela fosfatase alcalina reconstituída.

Assim, o projeto engloba estudos bioquímicos visando a caracterização cinética da fosfatase alcalina reconstituída em diferentes sistemas vesiculares, compreendendo os seguintes objetivos específicos:

- Padronização de uma metodologia para a obtenção de fosfatase alcalina pelo cultivo de células osteoblásticas provenientes de medula de rato;

- Caracterização cinética e bioquímica da fosfatase alcalina associada à membrana obtida de células osteoblásticas;

- Padronização de condições ótimas de solubilização da fosfatase alcalina empregando-se detergente (polidocanol) e fosfolipase (PIPLC);

- Remoção do detergente utilizando-se resina Calbiosorb;

- Padronização da reconstituição da fosfatase alcalina em lipossomos de diferentes composições lipídicas, constituídos somente de DPPC, de DPPC e DODAB ou de DPPC e DPPS;

- Padronização da reconstituição da enzima empregando-se células ghost resseladas;

- Caracterização cinética e bioquímica da fosfatase alcalina reconstituída nos diferentes sistemas vesiculares;

- Testes de liberação da enzima dos diferentes sistemas vesiculares utilizandose fosfolipase (PIPLC). 


\section{Material e Métodos}

\subsection{Obtenção e cultura de células de medula óssea de ratos}

As células de medula óssea de ratos foram obtidas e cultivadas conforme descrito por Simão e colaboradores (2007a). A medula óssea foi obtida de ratos machos jovens adultos da linhagem Wistar, pesando 110-120 g. O fêmur foi retirado assepticamente, limpo e lavado 4 vezes de 15 minutos em meio de cultura contendo 10 vezes a concentração usual de antibióticos (veja abaixo). As epífises foram removidas e a medula foi extraída com jato de $20 \mathrm{~mL}$ de meio de cultura esguichado por uma seringa de $20 \mathrm{~mL}$ com agulha de 20 gauges. As células liberadas foram cultivadas em frascos de $75 \mathrm{~cm}^{2}$ contendo meio essencial mínimo- $\alpha$ ( $\left.\alpha-M E M\right)$, suplementado com $15 \%$ de soro fetal bovino, $50 \mu \mathrm{g} / \mathrm{mL}$ de gentamicina, $0,3 \mu \mathrm{g} / \mathrm{mL}$ de fungizona, $10^{-7} \mathrm{M}$ de dexametazona, $5 \mu \mathrm{g} / \mathrm{mL}$ de ácido ascórbico e $7 \mathrm{mM}$ de $\beta$ glicerofosfato. As células foram cultivadas por 7, 14 e 21 dias, sempre mantidas a $37^{\circ} \mathrm{C}$ e atmosfera umidificada contendo $5 \%$ de $\mathrm{CO}_{2}$ e $95 \%$ de ar. Os meios foram trocados a cada 3 ou 4 dias.

\subsection{Formação de nódulos de matriz mineralizada}

Para observação dos nódulos de mineralização, ao final de 21 dias de cultura, o meio de cultura foi removido, os poços foram lavados três vezes com PBS a $37^{\circ} \mathrm{C}$ e preenchidos e mantidos com formalina 10\%, por 2 horas. Em seguida, foram desidratados em série crescente de álcoois e processados para coloração com vermelho de alizarina (Alizarin red $S$ ), que cora, em vermelho, nódulos de mineralização ricos em cálcio. Os poços foram, então, fotografados em microscópio de fase invertido em objetiva de $10 \mathrm{X}$.

\subsection{Obtenção das frações de membrana de osteoblastos}

As frações de membrana ricas em fosfatase alcalina foram extraídas das culturas osteoblásticas conforme descrito por Simão e colaboradores (2007a). As células que cresceram durante 14 dias em frasco plástico de cultura de $75 \mathrm{~cm}^{2}$ foram lavadas com tampão de estoque Tris- $\mathrm{HCl} 50 \mathrm{mM}, \mathrm{pH} 7,5$, contendo $\mathrm{MgCl}_{2} 2 \mathrm{mM}$, raspadas com espátula plástica e ressuspensas em $40 \mathrm{~mL}$ de tampão de choque osmótico Tris- $\mathrm{HCl} 50$ mM, pH 7,5, contendo $\mathrm{MgSO}_{4} 10 \mathrm{mM}$ e $\mathrm{NaCl}$ 0,8 M. O material 
ressuspenso foi homogeneizado empregando-se um homogeneizador do tipo "potter" e, em seguida, ultracentrifugado a $100.000 \times \mathrm{xg}$ por 1 hora, a $4^{\circ} \mathrm{C}$. O sobrenadante foi descartado e o pellet, que corresponde à fração de membrana de células osteoblásticas rica em fosfatase alcalina, foi ressuspenso em $5 \mathrm{~mL}$ de tampão de estoque. Este material foi fracionado em alíquotas de $1 \mathrm{~mL}$, rapidamente congelado e armazenado $\mathrm{a}-20^{\circ} \mathrm{C}$.

\subsection{Dosagem de proteína}

As concentrações de proteína foram determinadas pelo método descrito por Hartree (1972) na presença de SDS 2\% (p/v). A albumina de soro bovino foi utilizada como padrão. As determinações foram feitas em duplicatas e a concentração de proteína foi estimada a partir da curva padrão feita para cada dosagem.

\subsection{Determinação da atividade PNFFase}

A atividade PNFFase da enzima foi determinada descontinuamente, a $37^{\circ} \mathrm{C}$, através da formação do íon p-nitrofenolato $\left(\mathrm{PNF}^{-}\right)\left(\varepsilon=17.600 \mathrm{M}^{-1} \cdot \mathrm{cm}^{-1}, \mathrm{pH} 13\right)$, em $410 \mathrm{~nm}$, em tampão AMPOL $50 \mathrm{mM}, \mathrm{pH}$ 10,0, contendo $\mathrm{MgCl}_{2} 2 \mathrm{mM}$ e PNFF 10 $\mathrm{mM}$, em um volume final de $1 \mathrm{~mL}$, de acordo com o procedimento descrito por Simão e colaboradores (2007a). A reação foi iniciada pela adição da enzima ao meio reacional e interrompida pela adição de $\mathrm{NaOH} 1 \mathrm{M}$, em intervalos predeterminados. Em cada experimento foram incluídos controles sem a enzima para se estimar a hidrólise não enzimática do substrato. Uma unidade de enzima foi definida como sendo a quantidade de fosfatase alcalina que hidrolisa $1,0 \mathrm{nmol}$ de substrato por minuto, nas condições padrões do teste.

\subsection{Determinação da atividade ATPase}

A atividade ATPase da fosfatase alcalina foi determinada descontinuamente, a $37^{\circ} \mathrm{C}$, pela dosagem do fosfato inorgânico liberado, em tampão AMPOL $50 \mathrm{mM}, \mathrm{pH}$ 9,5, contendo $\mathrm{MgCl}_{2} 2 \mathrm{mM}$ e ATP $3 \mathrm{mM}$, em um volume final de 1,0 mL, como descrito por Simão e colaboradores (2007a). A reação foi iniciada pela adição da enzima ao meio reacional e interrompida pela adição de $0,5 \mathrm{~mL}$ de solução gelada de TCA 30\% (p/v), em intervalos predeterminados. Após homogeneização, os tubos foram colocados em banho de gelo para diminuir a hidrólise do ATP e imediatamente centrifugados por 10 minutos. Em seguida, foi efetuada a dosagem de fosfato, de 
acordo com o método descrito por Heinonen e Lahti (1981). Em cada experimento foram incluídos controles sem a enzima para se estimar a hidrólise não enzimática do substrato. Uma unidade de enzima foi definida como sendo a quantidade de fosfatase alcalina que hidrolisa $1,0 \mathrm{nmol}$ de substrato por minuto, nas condições padrões do teste.

\subsection{Determinação da atividade PPase}

A atividade PPase da enzima foi determinada descontinuamente, a $37^{\circ} \mathrm{C}$, pela dosagem do fosfato inorgânico liberado, em tampão AMPOL $50 \mathrm{mM}, \mathrm{pH}$ 9,0, contendo $\mathrm{MgCl}_{2} 2 \mathrm{mM}$ e pirofosfato $3 \mathrm{mM}$, em um volume final de $1 \mathrm{~mL}$, como descrito por Simão e colaboradores (2007a).

\subsection{Determinação da atividade de fosfomonohidrolase empregando-se outros substratos fosforilados}

A atividade de fosfomonohidrolase da fosfatase alcalina foi determinada descontinuamente, a $37^{\circ} \mathrm{C}$, empregando-se diferentes substratos: glicose-1-fosfato, glicose-6-fosfato, frutose-6-fosfato, ADP (adenosina difosfato) e $\beta$-glicerofosfato, todos na concentração final no tubo de $10 \mathrm{mM}$. O fosfato inorgânico liberado pela hidrólise destes substratos foi determinado em tampão AMPOL $50 \mathrm{mM}, \mathrm{pH} 10$, contendo $\mathrm{MgCl}_{2} 2 \mathrm{mM}$ e substrato $10 \mathrm{mM}$, em um volume final de 1,0 mL.

A reação enzimática sempre foi iniciada pela adição da enzima ao meio de reação e interrompida pela adição de $0,5 \mathrm{~mL}$ de solução gelada de TCA $30 \%(\mathrm{p} / \mathrm{v})$. Após homogeneização, os tubos foram colocados em gelo moído e processados conforme descrito por Simão e colaboradores (2007a). As determinações foram efetuadas em duplicatas e em cada experimento foram incluídos controles sem a enzima para se estimar a hidrólise não enzimática do substrato. As velocidades iniciais (já que menos de $5 \%$ do substrato foi hidrolisado) permaneceram constantes durante pelo menos 90 minutos. Uma unidade da enzima foi definida como sendo a quantidade de fosfatase alcalina que hidrolisa $1,0 \mathrm{nmol}$ de substrato por minuto, nas condições padrões do teste.

\subsection{Centrifugação em gradiente de densidade de sacarose}

Uma alíquota de $0,5 \mathrm{~mL}$ da fração de membrana foi aplicada sobre um gradiente contínuo de sacarose de 5-50\% (p/v), em tampão Tris-HCl 50 mM, pH 7,5, 
contendo $\mathrm{MgCl}_{2} 2 \mathrm{mM}$. Após 4 horas de ultracentifugação a 180.000xg, utilizando um rotor vertical (modelo P65VT3) de uma ultracentrífuga Hitachi (modelo 55PT-72), a $4^{\circ} \mathrm{C}$, alíquotas foram coletadas furando-se o fundo do tubo com uma agulha, a qual foi acoplada a um coletor calibrado para coletar frações de 0,5 mL, que foram analisadas quanto à concentração de proteína pelo método de Read e Northcote (1981), atividade PNFFase e porcentagem de sacarose por refratometria.

\subsection{Ação de inibidores sobre a atividade da fosfatase alcalina}

Esse estudo foi realizado utilizando-se os seguintes inibidores: vanadato (100 $\mu \mathrm{M}), \mathrm{ZnCl}_{2}(100 \mu \mathrm{M})$, levanisol $(100 \mu \mathrm{M})$, arsenato $(1 \mathrm{mM})$, fosfato $(10 \mathrm{mM}) \mathrm{e}$ teofilina (1 mM), conforme descrito por Simão e colaboradores (2007a). As soluções dos inibidores foram previamente preparadas no mesmo tampão do meio reacional e a atividade PNFFase da enzima foi determinada como descrito anteriormente.

\subsection{Efeito do tempo de incubação com polidocanol na solubilização da fosfatase alcalina}

Amostras da enzima associada à membrana contendo $0,2 \mathrm{mg} / \mathrm{mL}$ de proteína foram incubadas com polidocanol $1 \%(p / v)$ (concentração final), a $25^{\circ} \mathrm{C}$. Em intervalos predeterminados, cada alíquota foi ultracentrifugada a 100.000xg por uma hora, a $4^{\circ} \mathrm{C}$, e analisada quanto à atividade PNFFase.

\subsection{Efeito da concentração de proteína na solubilização da fosfatase alcalina}

Amostras da enzima associada à membrana com concentrações variáveis de proteína foram incubadas com polidocanol $1 \%(\mathrm{p} / \mathrm{v})$ (concentração final), a $25^{\circ} \mathrm{C}$. Após uma ultracentrifugação a $100.000 x g$ por uma hora, a $4^{\circ} \mathrm{C}$, cada alíquota foi analisada quanto à atividade PNFFase e concentração de proteína.

\subsection{Efeito da concentração de polidocanol na solubilização da fosfatase alcalina}

Amostras da enzima associada à membrana contendo $0,2 \mathrm{mg} / \mathrm{mL}$ de proteína foram incubadas com concentrações de polidocanol variando de 0,5 a $5 \%(\mathrm{p} / \mathrm{v})$, a $25^{\circ} \mathrm{C}$. Após uma ultracentrifugação a $100.000 \times$ xg por uma hora, a $4^{\circ} \mathrm{C}$, cada alíquota foi analisada quanto à atividade PNFFase e concentração de proteína. 


\subsection{Remoção do excesso de detergente}

A fosfatase alcalina solubilizada com polidocanol foi incubada sob agitação constante, durante 2 horas, a $4^{\circ} \mathrm{C}$, com a resina Calbiosorb na proporção de 200 $\mathrm{mg} / \mathrm{mL}$ (peso úmido), previamente tratada com metanol e equilibrada com tampão Tris- $\mathrm{HCl} 50 \mathrm{mM}, \mathrm{pH}$ 7,5, contendo $\mathrm{MgCl}_{2} 2 \mathrm{mM}$, conforme descrito por Camolezi e colaboradores (2002). Em intervalos de tempo preestabelecidos, alíquotas foram removidas e analisadas quanto ao conteúdo de detergente por RMN.

\subsection{Obtenção dos extratos de clorofórmio para análise por RMN}

Amostras de extrato de clorofórmio obtidas a partir de uma solução de polidocanol $1 \%(\mathrm{p} / \mathrm{v})$, da enzima solubilizada com polidocanol e da enzima solubilizada com polidocanol e tratada com a resina Calbiosorb foram submetidas à análise utilizando-se a técnica de ressonância magnética nuclear (RMN). A extração com clorofórmio foi realizada adicionando-se cerca de $1 \mathrm{~mL}$ de clorofórmio às amostras, separando-se a fase orgânica da fase aquosa e removendo-se o clorofórmio através da passagem de nitrogênio pela solução. Em seguida, foi adicionado clorofórmio deuterado às amostras e os espectros de ressonância magnética nuclear $\left({ }^{1} \mathrm{H}-\mathrm{RMN}\right)$ foram registrados a $400 \mathrm{MHz}$, em um equipamento Bruker (modelo Avance DRX 400). Os deslocamentos químicos estão relatados em parte por milhão (ppm) em relação ao tetrametilsilano (TMS).

\subsection{Preparação dos lipossomos}

Os lipossomos constituídos por DPPC, bem como os lipossomos mistos, constituídos por DPPC e DPPS 9:1 (razão molar) e 8:2 (razão molar) ou DPPC e DODAB 9:1 (razão molar) e 8:2 (razão molar), foram preparados dissolvendo-se 1 $\mathrm{mg}$ total/mL dos lipídios em clorofórmio e removendo-se o clorofórmio através da passagem de nitrogênio pela solução. Em seguida, o filme lipídico foi ressuspenso em tampão Tris- $\mathrm{HCl} 50 \mathrm{mM}, \mathrm{pH} 7,5$, contendo $\mathrm{MgCl}_{2} 2 \mathrm{mM}$ e a mistura foi incubada a $60^{\circ} \mathrm{C}$ por 1 hora, com agitações constantes em vortex a cada 10 minutos. Então, a mistura foi sonicada com um sonicador de ponta (VibraCell, modelo VC 600) até a solução se tornar translúcida e ultracentrifugada a $100.000 x g$ por 20 minutos, à temperatura ambiente, sendo o sobrenadante estocado a $4^{\circ} \mathrm{C}$. 


\subsection{Incorporação da fosfatase alcalina em lipossomos}

Amostras de lipossomos e fosfatase alcalina $(23 \mu \mathrm{g} / \mathrm{mL})$ em tampão Tris- $\mathrm{HCl}$ $50 \mathrm{mM}, \mathrm{pH} 7,5$, contendo $\mathrm{MgCl}_{2} 2 \mathrm{mM}$, foram misturadas e incubadas a $25^{\circ} \mathrm{C}$, por diferentes períodos de tempo, na proporção 1:1 (v/v). Em seguida, a solução foi ultracentrifugada a 100.000xg por 1 hora, a $4^{\circ} \mathrm{C}$, e o pellet foi ressuspenso em tampão Tris- $\mathrm{HCl} 50 \mathrm{mM}$, pH 7,5, contendo $\mathrm{MgCl}_{2} 2 \mathrm{mM}$. A atividade PNFFase total antes da ultracentrifugação e a atividade presente no sobrenadante e no pellet ressuspenso foram utilizadas para calcular a porcentagem de incorporação.

\subsection{Microscopia eletrônica com marcação negativa de lipossomos e proteolipossomos}

Este experimento foi realizado em colaboração com o laboratório do Prof. Dr. José Luis Millán, do Burnham Institute for Medical Research, La Jolla, Califórnia. Para a visualização dos lipossomos e proteolipossomos constituídos de DPPC por microscopia eletrônica, foi utilizada a técnica conhecida como marcação negativa, colocando-se $5 \mu \mathrm{L}$ da suspensão de lipossomos ou proteolipossomos em grades de cobre recobertas com carbono, por $1 \mathrm{~min}$, para a sedimentação das vesículas. $\mathrm{O}$ excesso de tampão foi removido, trocado por uma solução aquosa de acetato de uranila $(A U) 2 \%$ e incubado por 15 segundos; o excesso de $A U$ foi removido e as grades foram secas com ar por 2-5 min e colocadas no microscópio eletrônico para observação. O microscópio eletrônico de transmissão Hitachi H-600A foi operado a $75 \mathrm{kV}$ e com diferentes aumentos instrumentais. As imagens foram coletadas com CCD (charge coupled device, ou dispositivo de carga acoplada) resfriado por nitrogênio líquido (L9C) e câmera de 11,2 mega pixel (SIA).

\subsection{Estabilidade dos sistemas lipossomais}

A estabilidade dos lipossomos, bem como dos sistemas de proteolipossomos preparados, foi acompanhada através de medidas de distribuição de tamanho de partícula por espalhamento de luz dinâmico, empregando-se o equipamento Beckman Coulter (modelo N5), sendo as amostras previamente diluídas, de modo a se obter um índice de polidispersão adequado. A estabilidade da fosfatase alcalina incorporada aos lipossomos também foi acompanhada através da determinação da atividade PNFFase da enzima reconstituída em função do tempo de armazenamento dos proteolipossomos, a $4^{\circ} \mathrm{C}$. 


\subsection{Efeito do pH na atividade da fosfatase alcalina}

$\mathrm{O}$ efeito do $\mathrm{pH}$ sobre a atividade da fosfatase alcalina associada à membrana ou reconstituída nos lipossomos de DPPC foi determinado no intervalo de $\mathrm{pH}$ compreendido entre 5,0 e 10,5, conforme descrito por Simão e colaboradores (2007a), utilizando-se os seguintes tampões: MES (no intervalo de $\mathrm{pH}$ 5,0-6,0), bistris (no intervalo de $\mathrm{pH} 6,0-6,5$ ), Imidazol (no intervalo de $\mathrm{pH} 6,5-7,5$ ), Tris (no intervalo de $\mathrm{pH} 7,0-9,0$ ) e AMPOL (no intervalo de $\mathrm{pH}$ 9,0-10,5), todos na concentração final de $50 \mathrm{mM}$. As atividades PNFFase, ATPase e PPase foram determinadas conforme descrito anteriormente.

\subsection{Eletroforese em gel de poliacrilamida em condições desnaturantes (SDS- PAGE)}

As amostras protéicas, quando necessário, foram concentradas utilizando-se micro-concentradores (MICROCON 30) e posteriormente aplicadas em gel de poliacrilamida $7 \%$ ou $10 \%$, com gel de empilhamento $5 \%$. A eletroforese foi realizada de acordo com Laemmli (1970), utilizando-se nitrato de prata (Blum et al., 1987) para coloração de proteínas. Foram utilizados como padrões de massa molecular: miosina (205 kDa), $\beta$-galactosidase (116 kDa), fosforilase b (97 kDa), albumina de soro bovino (66 kDa), albumina de ovo (45 kDa) e anidrase carbônica (29 kDa). A atividade fosfohidrolítica no gel foi detectada em tampão AMPOL 50mM, pH 10, contendo $\mathrm{MgCl}_{2} 2 \mathrm{mM}$, Fast Blue RR-salt 0,12\% (p/v) e $\alpha$-naftilfosfato 0,12\% (p/v), a $37^{\circ} \mathrm{C}$.

\subsection{Preparação das células ghost resseladas}

As vesículas de células ghost foram preparadas como descrito por Doberstein e colaboradores (1995), substituindo-se os tampões originais, a base de fosfato de sódio, por tampões contendo Tris-HCl. Esta substituição se faz necessária porque o fosfato é um inibidor da fosfatase alcalina, sendo impossível monitorar a atividade da enzima em sua presença. A preparação dos eritrócitos resselados divide-se em três fases que devem ser realizadas em seqüência, sem nenhuma interrupção: (1) fase de obtenção e lavagem do sangue; (2) fase de hemólise dos eritrócitos e (3) fase de resselagem das membranas. Os seguintes tampões foram utilizados: (1) tampão de lavagem, constituído por Tris- $\mathrm{HCl} 18$ mM, pH 7,5, contendo $\mathrm{NaCl} 150$ mM e EDTA 1 mM; (2) tampão de hemólise, constituído por Tris-HCl 12 mM, pH 7,5 e (3) tampão 
de resselagem, constituído por Tris- $\mathrm{HCl} 398 \mathrm{mM}, \mathrm{pH} 8,0$, contendo $\mathrm{NaCl} 1,5 \mathrm{M} \mathrm{e}$ EDTA $10 \mathrm{mM}$.

Assim, foram retirados $5 \mathrm{~mL}$ de sangue humano, que foram centrifugados a $2.500 \mathrm{xg}$, por 10 minutos, a $4^{\circ} \mathrm{C}$. O plasma foi descartado e o pellet foi ressuspenso em $50 \mathrm{~mL}$ de tampão de lavagem, sendo centrifugado novamente a $2.500 \mathrm{xg}$, por 10 minutos, a $4^{\circ} \mathrm{C}$. O sobrenadante foi descartado e o procedimento de lavagem foi repetido mais três vezes como descrito acima, utilizando-se o mesmo tampão.

Após a última lavagem, iniciou-se a fase de hemólise dos eritrócitos, adicionando-se ao pellet restante $30 \mathrm{~mL}$ de tampão de hemólise gelado. A suspensão foi homogeneizada empregando-se um homogeneizador do tipo "potter" e incubada em banho de gelo por 20 minutos, sendo em seguida ultracentrifugada a $65.000 x g$, por 15 minutos, a $4^{\circ} \mathrm{C}$. O sobrenadante foi descartado e este procedimento foi repetido enquanto observou-se coloração vermelha no pellet (sugestiva de contaminação por hemoglobina).

Com a obtenção de um pellet esbranquiçado, iniciou-se a fase de resselagem das membranas, adicionando-se ao pellet restante $20 \mathrm{~mL}$ de tampão de resselagem para cada $\mathrm{mL}$ de pellet e incubando-se a suspensão por 45 minutos, a $37^{\circ} \mathrm{C}$. As células ghost resultantes $(0,22 \mathrm{mg} / \mathrm{mL})$ foram ultracentrifugada a $65.000 \mathrm{xg}$, por 15 minutos, a $4^{\circ} \mathrm{C}$, ressuspensas em tampão de estoque, fracionadas em alíquotas de 1 $\mathrm{mL}$, rapidamente congeladas e armazenadas a $-20^{\circ} \mathrm{C}$.

\subsection{Incorporação da fosfatase alcalina às células ghost resseladas}

Amostras de células ghost $(0,22 \mathrm{mg} / \mathrm{mL})$ e fosfatase alcalina $(23 \mu \mathrm{g} / \mathrm{mL}) \mathrm{em}$ tampão Tris- $\mathrm{HCl} 50 \mathrm{mM}, \mathrm{pH} 7,5$, contendo $\mathrm{MgCl}_{2} 2 \mathrm{mM}$, foram misturadas e incubadas a $25^{\circ} \mathrm{C}$, por 2 horas, na proporção $1: 1(\mathrm{v} / \mathrm{v})$. Em seguida, a solução foi ultracentrifugada a 100.000xg por 1 hora, a $4^{\circ} \mathrm{C}$, e o pellet foi ressuspenso em tampão Tris- $\mathrm{HCl} 50 \mathrm{mM}$, pH 7,5, contendo $\mathrm{MgCl}_{2} 2 \mathrm{mM}$, ao volume original. A atividade PNFFase total antes da ultracentrifugação e a atividade presente no sobrenadante e no pellet ressuspenso foram utilizadas para calcular a porcentagem de incorporação.

\subsection{Microscopia eletrônica das células ghost resseladas}

O pellet obtido após ultracentrifugação das células ghost a 65.000xg, por 15 minutos, a $4^{\circ} \mathrm{C}$, foi fixado com glutaraldeído $3 \%(\mathrm{p} / \mathrm{v})$, em tampão fosfato de sódio 
$0,1 \mathrm{M}, \mathrm{pH} 7,3$, por 3 horas, à temperatura ambiente, lavado com tampão fosfato de sódio 0,1 M, pH 7,3 e pós-fixado com solução de tetróxido de ósmio 1\% (p/v) em tampão fosfato de sódio $0,1 \mathrm{M}, \mathrm{pH} 7,3$. Após duas horas, o pellet foi lavado com tampão fosfato de sódio $0,1 \mathrm{M}, \mathrm{pH} 7,3$, centrifugado e desidratado com concentrações crescentes de acetona (30,50, 70, 90, 95 e 100\%), com intervalos de 10 minutos entre cada troca. A última desidratação foi realizada com acetona $100 \%$ durante 20 minutos, por 3 vezes. Finalmente, o pellet foi infiltrado em resina de araldite 6005 (1:1), a temperatura ambiente, durante 48 horas e incluso em araldite pura por 72 horas, a $60^{\circ} \mathrm{C}$. O corte obtido utilizando-se um ultramicrótono foi contrastado com acetato de uranila, por 30 minutos, seguido por citrato de chumbo, por 3 minutos, sendo a amostra examinada utilizando-se um microscópio eletrônico Philips modelo 208.

\subsection{Efeito da concentração de substratos sobre a atividade da enzima}

O estudo do efeito da concentração de substratos sobre a atividade enzimática da fosfatase alcalina associada à membrana ou reconstituída nos diferentes lipossomos e em células ghost foi realizado conforme o descrito anteriormente, variando-se a concentração de substrato no meio reacional.

\subsection{Obtenção da enzima solubilizada com fosfolipase C}

A fosfatase alcalina foi incubada com fosfolipase $C$ de Bacillus thuringiensis (PIPLC) na proporção de $1 \mathrm{mg} / \mathrm{mL}$ de proteína com 0,2 unidades de fosfolipase para a enzima associada à membrana ou 0,2 unidades de fosfolipase $/ \mathrm{mL}$ para a enzima reconstituída nos lipossomos de DPPC e em células ghost, em tampão Tris- $\mathrm{HCl} 50$ $\mathrm{mM}, \mathrm{pH} 7,5$, contendo $\mathrm{MgCl}_{2} 2 \mathrm{mM}$. A mistura foi mantida durante 2 horas, a $37^{\circ} \mathrm{C}$, sob agitação constante, e em seguida foi ultracentrifugada durante 1 hora, a 100.000xg, a $4^{\circ} \mathrm{C}$, sendo o pellet ressuspenso em tampão Tris- $\mathrm{HCl} 50 \mathrm{mM}, \mathrm{pH} 7,5$, contendo $\mathrm{MgCl}_{2} 2 \mathrm{mM}$, ao volume original.

\subsection{Análise dos dados cinéticos}

Os parâmetros cinéticos de hidrólise dos substratos, obtidos nas diferentes condições experimentais: $\mathrm{K}_{0,5}$ (constante de Michaelis Menten), $\mathrm{n}$ (coeficiente de Hill) e $V_{m}$ (velocidade máxima) foram calculados empregando-se o programa SigrafW (Leone et al., 2005). 


\section{Resultados e Discussão}

\subsection{Obtenção e caracterização da fosfatase alcalina de membrana}

Células da medula óssea podem ser isoladas, cultivadas e induzidas a se diferenciar em células envolvidas no processo de calcificação, como condrócitos ou osteoblastos (Phinney, 2002; Prockop et al., 2003; Osyczka e Leboy, 2005). Muitos estudos têm demonstrado que os estágios de diferenciação para se alcançar o fenótipo osteoblástico necessitam da expressão coordenada de muitas moléculas (Cheng et al., 1996; Osyczka e Leboy, 2005; van den Dolder e Jansen, 2007). Além da expressão de colágeno tipo I, osteopontina, sialoproteína óssea e osteocalcina, altos níveis de fosfatase alcalina também são induzidos durante a diferenciação dos osteoblastos para o processo de mineralização (Cheng et al., 1996; Osyczka e Leboy, 2005; van den Dolder e Jansen, 2007), fornecendo um modelo útil para a investigação das alterações temporais e espaciais na expressão de marcadores osteoblásticos. Vários estudos indicam que o sistema de células de medula óssea é um modelo útil para se estudar tanto a expressão temporal e espacial de proteínas relacionadas ao processo de biomineralização durante a osteogênese, bem como a formação, mineralização e maturação de nódulos ósseos (Simão et al., 2007a,b; van den Dolder e Jansen, 2007).

Assim, as células da medula óssea de rato foram cultivadas por diferentes períodos de tempo, diferenciando-se e aderindo no fundo do frasco de cultura, e a partir de $24 \mathrm{~h}$ (Figura 1A) pode ser observado o aumento significativo de células osteoblásticas com o passar do tempo: 4 dias (Figura 1B), 10 dias (Figura 1C) e 14 dias (Figura 1D). Além disso, com 14 dias já podem ser visualizados nódulos de mineralização (Figura 1D), e se esta cultura for processada e corada com vermelho de alizarina (Alizarin red $S$ ), adquire coloração característica de material mineralizado (Figura 1D'). As culturas foram monitoradas durante 21 dias de crescimento quanto aos níveis de proteína e atividade de fosfatase alcalina, sendo interrompidas após 7, 14 e 21 dias para o processamento das células e obtenção da fração de membrana.

A variação com o tempo de cultura da atividade PNFFase e da concentração de proteína presentes na fração de membrana é mostrada na Figura 1E. Este procedimento sem o uso de colagenase e/ou protease usado para se obter a enzima associada à membrana resultou em uma preparação com altos níveis de atividade 


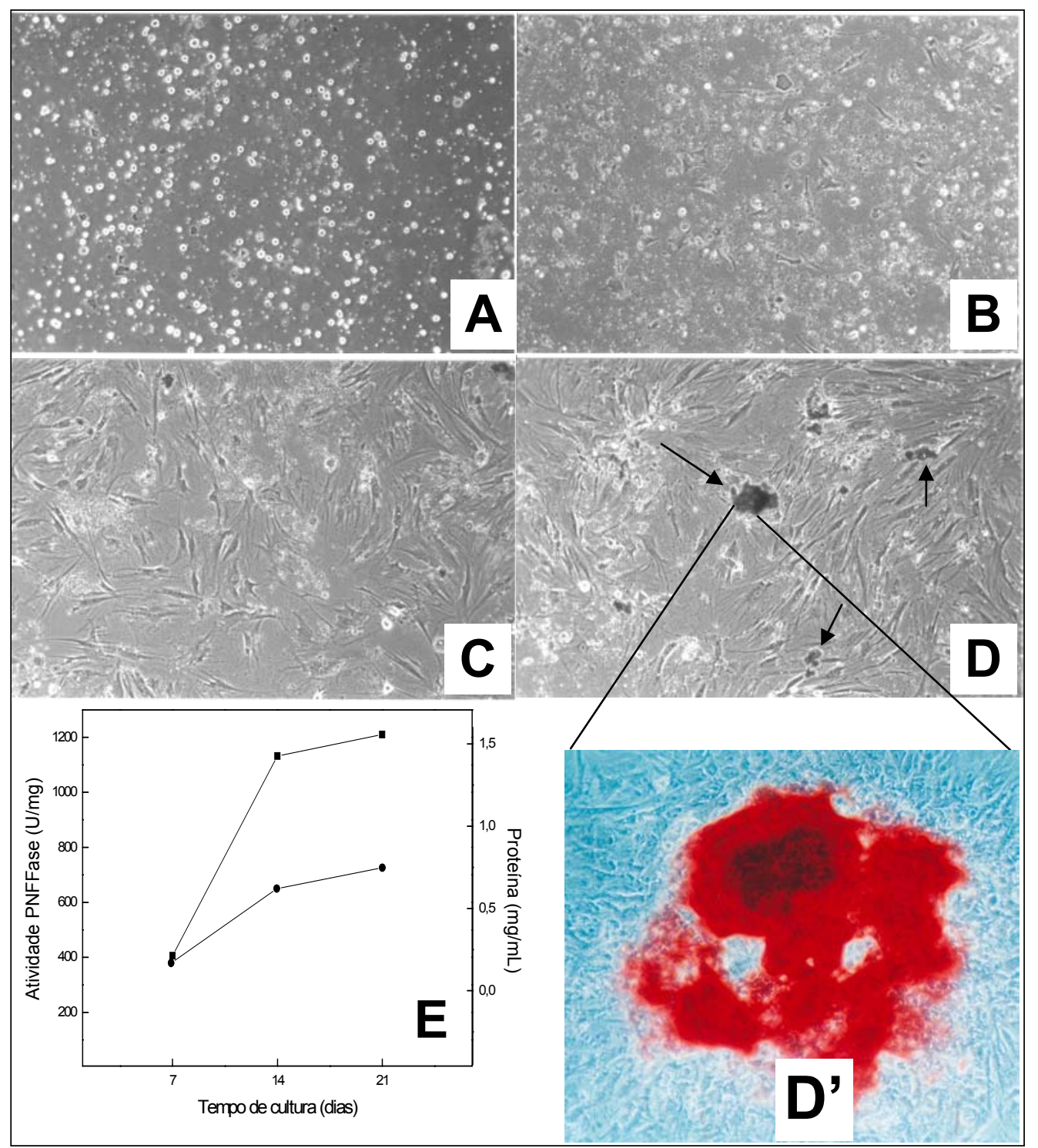

Figura 1. Cultura de células osteoblásticas após (A) 24 h; (B) 4 dias; (C) 10 dias; (D) 14 dias e (D') coloração com vermelho de alizarina. As células foram cultivadas por 14 dias em meio essencial mínimo- $\alpha$ ( $\alpha$-MEM), suplementado com $15 \%$ de soro fetal bovino, $50 \mu \mathrm{g} / \mathrm{mL}$ de vancomicina, $20 \mu \mathrm{g} / \mathrm{mL}$ de ampicilina, $0,3 \mu \mathrm{g} / \mathrm{mL}$ de fungizona, $10^{-7} \mathrm{M}$ de dexametazona, $5 \mu \mathrm{g} / \mathrm{mL}$ de ácido ascórbico e $7 \mathrm{mM}$ de $\beta$-glicerofosfato. Aumento: $10 \times$ (as setas indicam matriz mineralizada). (E) Efeito do tempo de crescimento das culturas de células osteoblásticas na atividade PNFFase e concentração de proteína da fração de membrana rica em fosfatase alcalina. Após 7 , 14 e 21 dias, o crescimento foi interrompido e as células foram processadas conforme descrito no item 3.3 de Material e Métodos. A fração de membrana foi analisada quanto à $(\bullet)$ concentração de proteína e $(\boldsymbol{\square})$ atividade PNFFase, conforme descrito nos itens 3.4 e 3.5, respectivamente, de Material e Métodos. 
de fosfomonohidrolase e concentração de proteína. Níveis máximos de atividade PNFFase e concentração de proteína foram obtidos após 14 dias de cultura, com valores ao redor de $1.200 \mathrm{U} / \mathrm{mg}$ e 0,6 mg/mL, respectivamente. Resultados contraditórios têm sido encontrados para o padrão de expressão de fosfatase alcalina por osteoblastos obtidos de células de medula humana, calvária de ratos recém-nascidos e ossos longos de bois recém-nascidos, mostrando atividade máxima após três semanas em cultura (Owen et al., 1990; Stein et al., 1990; Ibaraki et al., 1992; Cheng et al., 1996; Ferrera et al., 2002; Millán, 2006). Além das diferentes origens das células e, consequentemente, do uso destas em diferentes estágios de diferenciação osteoblástica, tais disparidades no padrão de expressão da enzima podem ser atribuídas às condições de cultura. Os resultados aqui obtidos estão de acordo com aqueles relatados por Curti e colaboradores (1986), que mostraram que a indução do processo de mineralização atinge valores máximos de atividade PNFFase 14 dias após o implante de matriz óssea desmineralizada. Não se tem uma explicação lógica para justificar a coincidência entre os dois métodos de obtenção da enzima, tanto pelo cultivo de células osteoblásticas quanto pelo processo de indução ectópica, e para isso serão necessários estudos mais detalhados. No entanto, os valores de atividade PNFFase obtidos para as culturas osteoblásticas são aproximadamente 3 vezes maiores do que aqueles obtidos pelo processo de mineralização induzida.

Para comprovar a eficiência do método proposto para a obtenção de uma fração de membrana rica em fosfatase alcalina, uma série de experimentos foi realizada com o objetivo de caracterizar esta fração de membrana.

Como primeiro experimento foi realizado um gradiente de centrifugação em sacarose (Figura 2). A posição do pico de atividade PNFFase se concentrou ao redor de 20-25\% de sacarose, característico de uma fração de membrana, descartando-se a possibilidade de contaminantes protéicos solúveis com atividade de fosfomonohidrolase. Resultados similares foram encontrados para a enzima obtida de cartilagem induzida por matriz óssea de rato (Curti et al., 1986).

$\mathrm{O}$ pH ótimo aparente para a hidrólise do PNFF pela fração de membrana rica em fosfatase alcalina variou com a concentração de substrato, tornando-se mais ácido em concentrações menores (resultados não mostrados). Esta dependência do $\mathrm{pH}$ ótimo aparente com a concentração do substrato é um comportamento característico de fosfatases alcalinas obtidas de diversas fontes, e está de acordo 


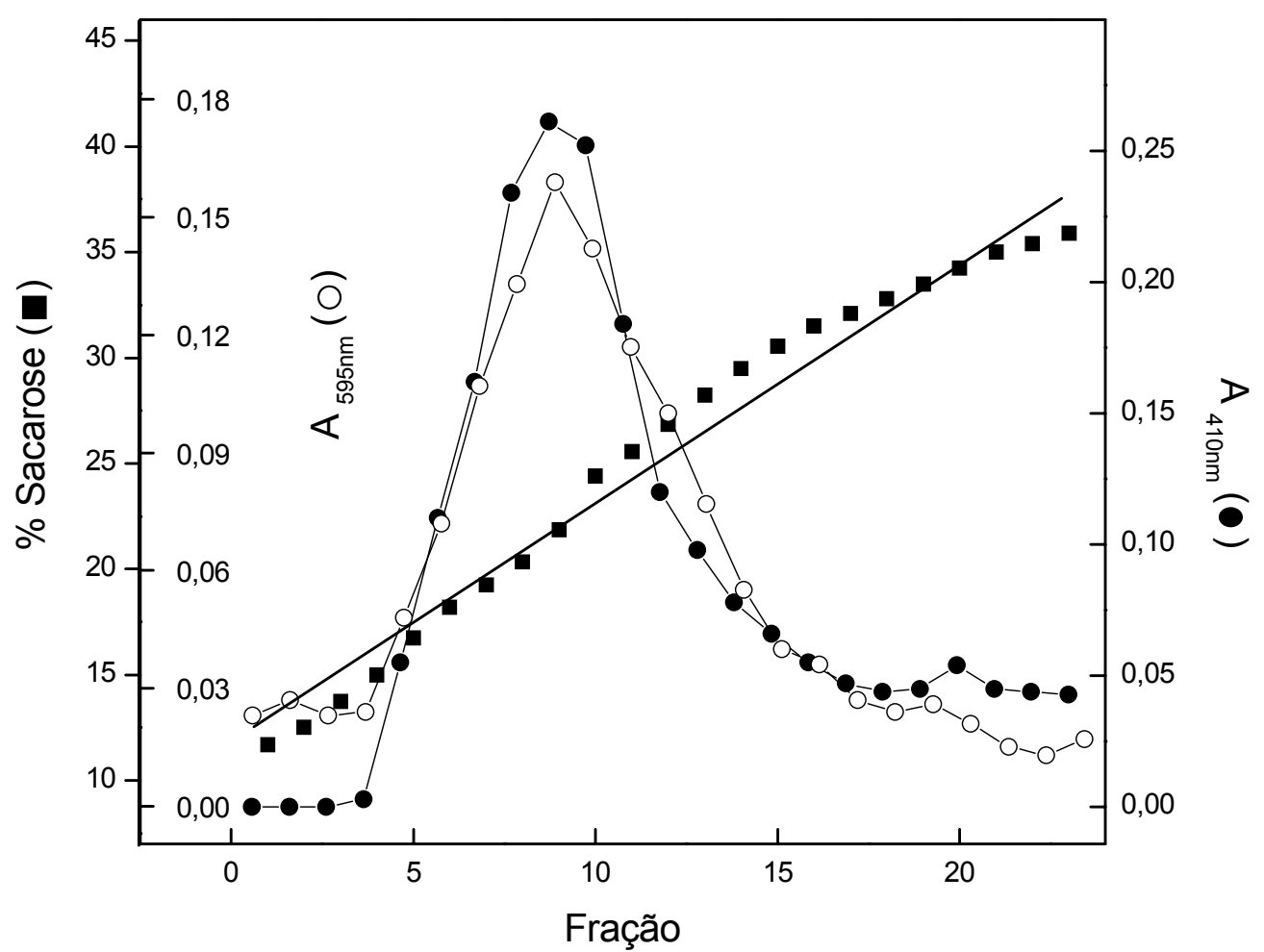

Figura 2. Centrifugação em gradiente de sacarose da fração de membrana rica em fosfatase alcalina obtida a partir da cultura de células osteoblásticas por 14 dias. Uma alíquota de $500 \mu \mathrm{L}$ em tampão Tris- $\mathrm{HCl} 50$ mM, pH 7,5, contendo $\mathrm{MgCl}_{2} 2 \mathrm{mM}$ foi aplicada no topo de um gradiente contínuo de sacarose (5-50\% p/v) e submetida à ultracentrifugação, durante 4 horas, a $180.000 x g$, a $4^{\circ} \mathrm{C}$. Frações de $0,5 \mathrm{~mL}$ foram coletadas e analisadas por $(O)$ concentração de proteína $\left(A_{595 n m}\right)$, ( $\left.\mathbf{\square}\right)$ porcentagem de sacarose e $(\bullet)$ atividade PNFFase conforme descrito no item 3.9 de Material e Métodos. 
com dados relatados para a enzima solúvel (Say et al., 1991), solubilizada com fosfolipase C (Pizauro et al., 1995), solubilizada com detergente (Pizauro et al., 1988) e associada à membrana (Rezende et al., 1993). No entanto, na presença de $10 \mathrm{mM}$ de substrato e $\mathrm{MgCl}_{2} 2 \mathrm{mM}$, um pH ótimo de 10 foi determinado (Figura 3), semelhante ao descrito para outras fosfatases alcalinas obtidas de diferentes fontes (McComb et al., 1979; Simão et al., 2007b).

O procedimento utilizado em cinética do estado estacionário para se investigar a interação entre ligantes e a enzima consiste em variar a concentração de um ligante e manter fixa a concentração dos outros. A comparação de parâmetros cinéticos $\left(\mathrm{V}_{\mathrm{m}}, \mathrm{K}_{0,5}, \mathrm{n}\right.$, entre outros) é complexa e requer metodologias com rígidos controles e condições ótimas de $\mathrm{pH}$, espécie tamponante, presença de diferentes íons, entre outros. Para adequarmos as condições experimentais de cinética enzimática, foram realizados dois experimentos, onde foram variados a quantidade de enzima (Figura 4A) e o tempo de incubação (Figura 4B) durante o ensaio de atividade PNFFase. Como pode ser observado, as curvas apresentaram comportamento linear e foi padronizado o ensaio de cinética sem a hidrólise do substrato em excesso (menos que 5\%) e sem o emprego de quantidades excessivas de enzima.

A eletroforese da fração de membrana rica em fosfatase alcalina, em gel de poliacrilamida $10 \%$, revelou a presença de muitas proteínas (Figura 5A, gel 2), entretanto somente um componente protéico apresentou atividade de fosfomonohidrolase (Figura 5A, gel 3). Este resultado sugere fortemente que a fração de membrana apresenta somente uma proteína com atividade de fosfomonohidrolase na condição experimental efetuada, com massa molecular ao redor de $120 \mathrm{kDa}$. A massa molecular descrita para a enzima é muito semelhante à descrita para outras fosfatases (McComb et al., 1979; Pizauro et al., 1987; Ciancaglini et al., 1990a; Leone et al., 1997a; Simão et al., 2007b). No entanto, este valor é $17 \%$ menor quando comparado àquele relatado para fosfatase alcalina osteoblástica de culturas de células ósseas humanas (Radisson et al., 1996). Esta diferença não é significativa, já que a enzima é constituída de duas subunidades e esta técnica não é precisa o suficiente para diferenciar massas moleculares muito similares. Além disso, este comportamento pode ser justificado devido às diferenças no grau de glicosilação da enzima obtida de diferentes fontes e ao uso de diferentes protocolos de culturas. Quando este componente protéico foi extraído, incubado com 


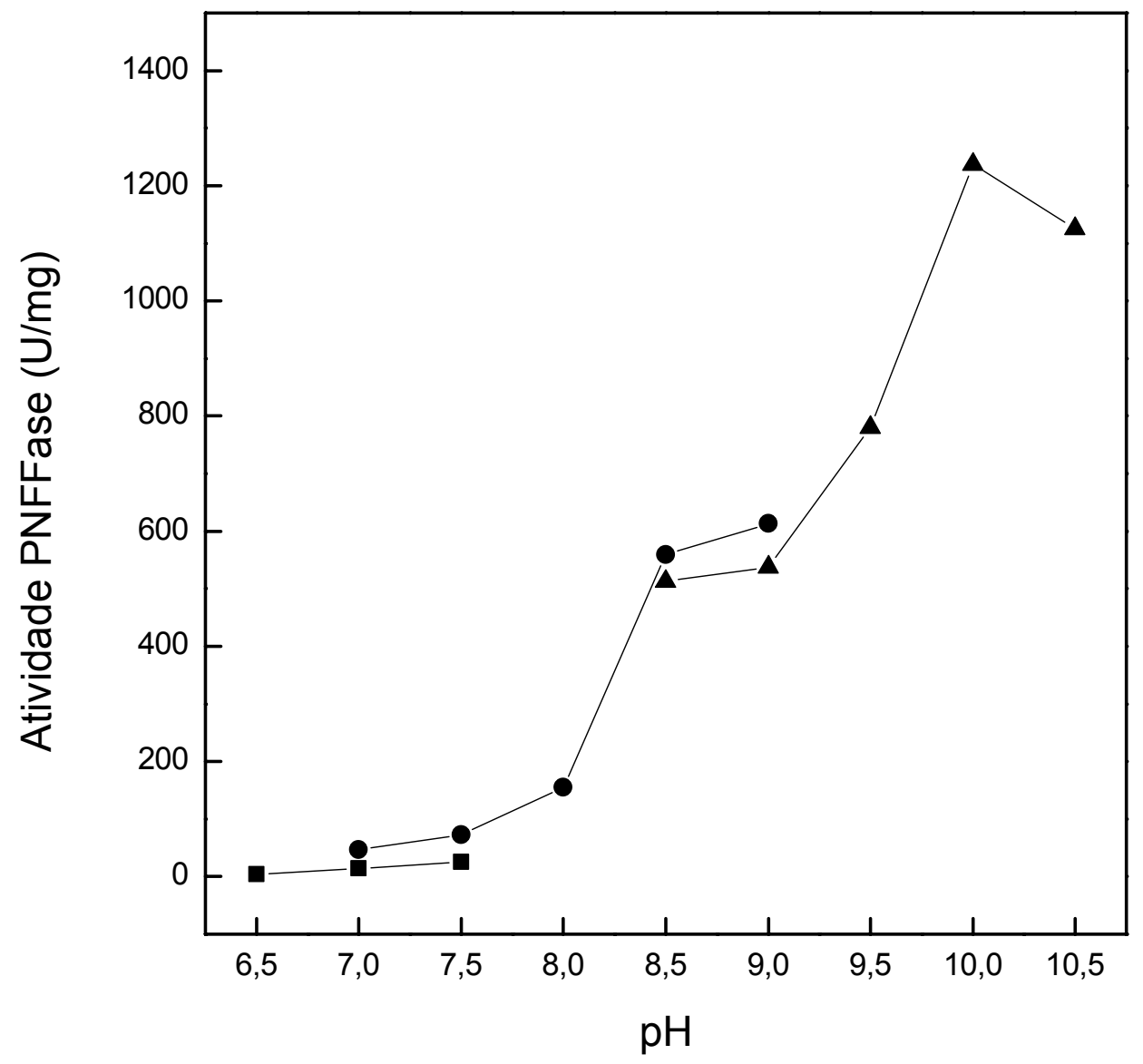

Figura 3. Determinação do pH ótimo de hidrólise do PNFF pela fração de membrana rica em fosfatase alcalina, obtida a partir de células osteoblásticas cultivadas por 14 dias, na faixa de pH entre 6,5 e 10,5, utilizando-se os seguintes tampões:

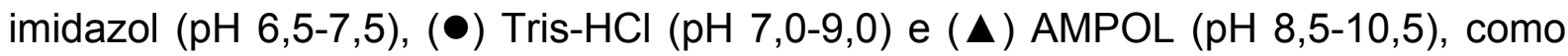
descrito no item 3.20 de Material e Métodos. As atividades foram determinadas em $50 \mathrm{mM}$ do tampão apropriado, contendo $\mathrm{MgCl}_{2} 2 \mathrm{mM}$ e PNFF $10 \mathrm{mM}$, como descrito no item 3.5 de Material e Métodos. 


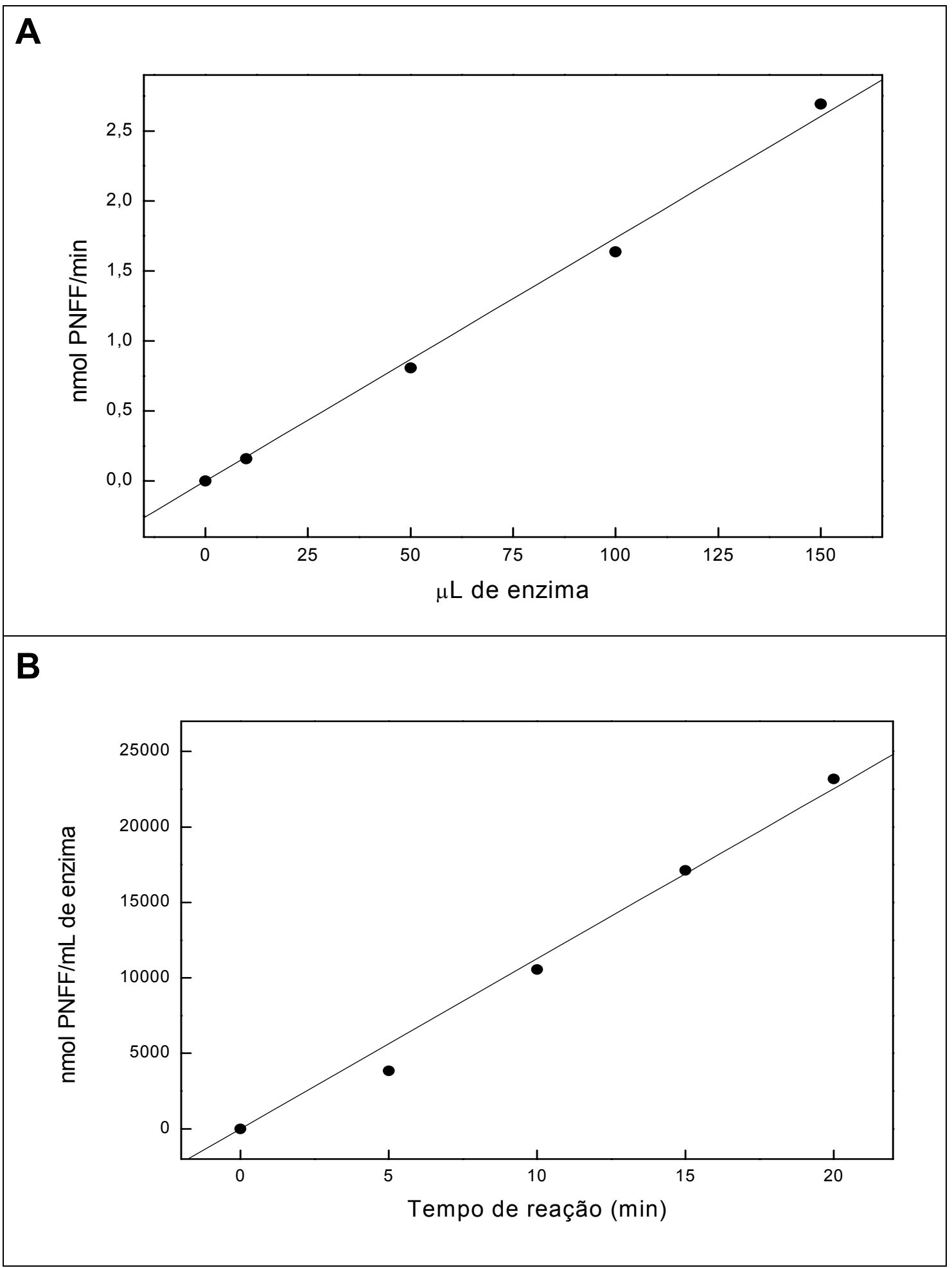

Figura 4. Efeito da (A) concentração de enzima e (B) tempo de reação na atividade PNFFase da fração de membrana rica em fosfatase alcalina, obtida a partir da cultura de células osteoblásticas por 14 dias. A atividade PNFFase foi determinada conforme descrito no item 3.5 de Material e Métodos. 


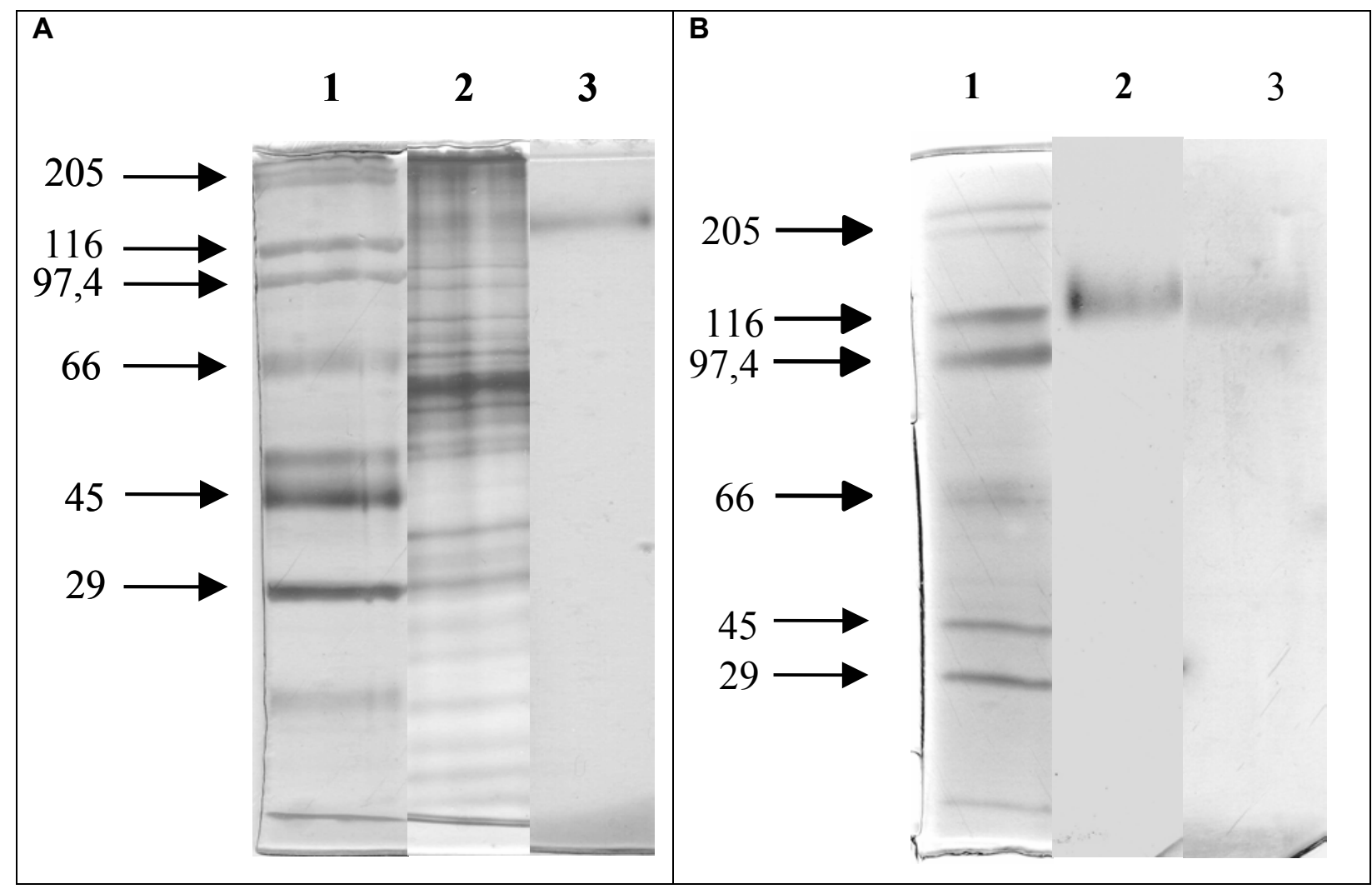

Figura 5. Eletroforese em gel de poliacrilamida em condições desnaturantes da fração de membrana rica em fosfatase alcalina, realizada conforme descrito no item 3.21 de Material e Métodos. Os géis foram revelados utilizando-se nitrato de prata ou renaturados com tampão Tris- $\mathrm{HCl} 50 \mathrm{mM}, \mathrm{pH}$ 7,5 e revelados para atividade fosfomonohidrolítica. (A) A eletroforese foi realizada em um gel de poliacrilamida 10\%. Gel 1: padrões de massa molecular; Gel 2: fração de membrana rica em fosfatase alcalina; Gel 3: atividade fosfohidrolítica da fração de membrana rica em fosfatase alcalina. (B) A eletroforese foi realizada em um gel de poliacrilamida $7 \%$. Gel 1: padrão de peso molecular; Gel 2: atividade fosfohidrolítica da fosfatase alcalina solubilizada com PIPLC; Gel 3: atividade fosfohidrolítica da fosfatase alcalina solubilizada com polidocanol. A atividade foi detectada em tampão AMPOL $50 \mathrm{mM}, \mathrm{pH}$ 10, contendo $\mathrm{MgCl}_{2} 2 \mathrm{mM}$, Fast Blue RR-salt 0,12\% (p/v) e $\alpha$-naftilfosfato $0,12 \%(p / v)$, a $37^{\circ} \mathrm{C}$. 
$\beta$-mercaptoetanol e novamente submetido à SDS-PAGE, foi revelada uma massa molecular ao redor de $60 \mathrm{kDa}$, mas a atividade de fosfomonohidrolase não aparece mais. Este resultado sugere que a enzima é constituída de duas subunidades iguais e que a atividade de hidrólise é dependente da forma dimérica (resultados não mostrados).

Uma vez que com os experimentos mostrados até o momento fica evidente a presença de apenas uma entidade protéica com atividade de fosfomonohidrolase em $\mathrm{pH}$ alcalino, foram avaliadas algumas características cinéticas da enzima presente na membrana, com o intuito de se conhecer os parâmetros cinéticos (como padrões para comparação com outras formas) e também confirmar se tratar de uma fosfatase alcalina, antes de serem iniciadas todas as etapas de solubilização e purificação.

As principais características de hidrólise da fosfatase alcalina presente na fração de membrana de células osteoblásticas em relação a diversos substratos analisados, mostradas na Tabela 1, sugerem que a enzima pode agir como uma fosfomonohidrolase inespecífica ou multifuncional (E.C. 3.1.3.1.), hidrolisando PNFF, ATP, PP, ADP, $\beta$-glicerofosfato, glicose-1-fosfato, glicose-6-fosfato e frutose-6fosfato.

Tabela 1. Atividade de fosfomonohidrolase da fração de membrana rica em fosfatase alcalina obtida conforme descrito no item 3.3 de Material e Métodos, após 14 dias de cultura.

\begin{tabular}{lcc}
\hline Substrato [10 $\mathbf{~ m M}]$ & Atividade (U/mg) & Atividade (\%) \\
\hline PNFF & $1.317,4$ & 100,0 \\
ADP & 352,2 & 26,7 \\
ATP & 240,2 & 18,3 \\
Glicose-1-fosfato & $1.094,6$ & 83,1 \\
Glicose-6-fosfato & 339,7 & 25,8 \\
Frutose-6-fosfato & 465,2 & 35,3 \\
ß-glicerofosfato & 654,3 & 49,7 \\
Pirofosfato & 330,4 & 25,0 \\
\hline
\end{tabular}


Dos substratos estudados, o que apresentou uma maior velocidade de hidrólise foi o PNFF, que não é um substrato natural da enzima. Considerando os valores de hidrólise relatados para a fosfatase alcalina ligada à membrana obtida de placas ósseas (Pizauro et al., 1987), a enzima associada à membrana obtida de culturas de células osteoblásticas apresenta maior habilidade para hidrolisar glicose1-fosfato e menor habilidade de hidrólise do ATP, já que estas atividades representaram $83,1 \%$ e $18,3 \%$, respectivamente, quando comparadas com as observadas para o PNFF (Tabela 1). Outra diferença significativa é o fato desta fração de membrana hidrolisar mais lentamente ADP $(26,7 \%)$, frutose-6-fosfato $(35,3 \%)$, glicose-6-fosfato $(25,8 \%)$ e $\beta$-glicerofosfato $(49,7 \%)$, quando comparada com as velocidades de hidrólise destes substratos relativamente mais rápidas observadas para a enzima solúvel e purificada obtida de placas ósseas (Say et al., 1991). O pirofosfato, por sua vez, exibiu velocidades relativas de hidrólise muito semelhantes para a enzima ligada à membrana de células osteoblásticas e para a fosfatase alcalina solúvel e purificada obtida de placas ósseas (Say et al., 1991). Levando-se em consideração estes resultados, pode-se concluir que há diferenças significativas entre a fosfatase alcalina associada à membrana obtida de culturas de células osteoblásticas, a enzima solúvel purificada de placas ósseas (Say et al., 1991) e a enzima ligada à membrana obtida de placas ósseas (Pizauro et al., 1987).

Com o objetivo de se verificar o comportamento da fração de membrana frente a diferentes inibidores da atividade PNFFase, foi realizado um ensaio com vários compostos característicos como inibidores de fosfatase alcalina (Tabela 2). A atividade PNFFase desta fração de membrana foi inibida eficientemente por $100 \mu \mathrm{M}$ de levanisol, $1 \mathrm{mM}$ de teofilina e $100 \mu \mathrm{M}$ de $\mathrm{ZnCl}_{2}$ (66\%, 72\% e 68\% de inibição da atividade, respectivamente). Além disso, $100 \mu \mathrm{M}$ de vanadato, $10 \mathrm{mM}$ de fosfato e 1 $\mathrm{mM}$ de arsenato também reduziram moderadamente a atividade PNFFase da enzima (46\%, 21\% e $44 \%$ de inibição da atividade, respectivamente). Estes resultados, mais uma vez, sugerem fortemente que a fração de membrana obtida pelo cultivo de células osteoblásticas seja rica em fosfatase alcalina. Os menores índices de inibição, observados para os inibidores clássicos que apresentam comportamento competitivo, são devidos à concentração de PNFF utilizada (10 mM) no meio reacional (Kozlenkov et al., 2004). Deve ser chamada a atenção para a inibição com levanisol e teofilina, pois estes dois compostos são específicos para 
fosfatases (via intermediário fosforilado), sugerindo que a atividade detectada tanto com PNFF quanto com outro substrato se deve a uma fosfatase que apresenta $\mathrm{pH}$ ótimo na região alcalina (Fortuna et al., 1979; Cyboron e Wuthier, 1981; Hsu et al., 1985; Curti et al., 1986; Gonçalves et al., 2002; Kozlenkov et al., 2004).

Tabela 2. Efeito de diferentes inibidores sobre a atividade PNFFase da fração de membrana rica em fosfatase alcalina, obtida a partir de células osteoblásticas cultivadas por 14 dias. A atividade PNFFase foi determinada conforme descrito no item 3.5 de Material e Métodos.

\begin{tabular}{lcc}
\hline Inibidor & $\begin{array}{c}\text { Concentração } \\
(\mathbf{m M})\end{array}$ & $\begin{array}{c}\text { Atividade PNFFase } \\
\text { residual (\%) }\end{array}$ \\
\hline Controle & - & 100,0 \\
Vanadato & 0,1 & 53,8 \\
$\mathrm{ZnCl}_{2}$ & 0,1 & 31,9 \\
Levanisol & 0,1 & 34,4 \\
Arsenato & 1 & 56,0 \\
Fosfato & 10 & 78,8 \\
Teofilina & 1 & 28,2 \\
\hline
\end{tabular}

Outras enzimas também podem ser encontradas nesta fração de membrana, tais como NPP1 (ou PC-1, NPP) e PHOSPHO1. NPP1 é uma proteína integral de membrana com $130 \mathrm{kDa}$, apresentando $\mathrm{pH}$ ótimo ao redor de 7,4-8,8, que não responde a inibidores clássicos de fosfatases alcalinas. PHOSPHO1 tem massa molecular ao redor de $32 \mathrm{kDa}$ e pH ótimo de 6,7 (Anderson et al., 2004; Roberts et al., 2004). Considerando que um $\mathrm{pH}$ de 10 foi utilizado para monitorar a atividade PNFFase da fosfatase alcalina associada à membrana, a possibilidade da atividade de fosfomonohidrolase ser atribuída às enzimas descritas acima foi excluída.

Uma vez que com os experimentos mostrados até o momento fica evidente a presença de apenas uma entidade protéica com atividade de fosfomonohidrolase em $\mathrm{pH}$ alcalino, foram avaliadas algumas características cinéticas da enzima presente na membrana, com o intuito de se conhecer os parâmetros cinéticos (como padrões para comparação com outras formas da enzima) e também confirmar se tratar de 
uma fosfatase alcalina, antes de serem iniciadas todas as etapas de solubilização e purificação.

Na Figura 6 são mostrados os efeitos da concentração de PNFF, ATP e PPi sobre a atividade da enzima associada à membrana. Os parâmetros cinéticos obtidos estão resumidos na Tabela 3. Além do PNFF, estes estudos foram realizados utilizando-se ATP e $\mathrm{PP}_{\mathrm{i}}$, que são substratos naturais da enzima e têm também uma importante função no processo de biomineralização, pois o $\mathrm{PP}_{\mathrm{i}}$ é um inibidor conhecido do processo de mineralização e os produtos de hidrólise de ambos os substratos são reguladores da atividade da enzima (Pizauro et al., 1987; Rezende et al., 1998; Leone et al., 1997a; Garimella et al., 2006; Anderson, 1995, 2003). Os valores de $\mathrm{K}_{0,5}$ obtidos para a hidrólise dos diferentes substratos pela enzima associada à membrana (Simão et al., 2007a) são semelhantes àqueles relatados para a enzima ligada à membrana obtida de placas ósseas e de culturas de células osteoblásticas de osso alveolar humano (Pizauro et al., 1987; Ciancaglini et al., 1990a, 2006; Simão et al., 2007b). Quando PNFF foi usado como substrato (Figura 6), a enzima exibiu um comportamento Michaeliano, similar aos resultados descritos para a enzima associada à membrana e solubilizada com Triton X-100 ou polidocanol, obtida de placas ósseas de rato (Pizauro et al., 1987; Ciancaglini et al., 1990a) e para a enzima associada à membrana de culturas de células osteoblásticas de osso alveolar humano (Simão et al., 2007b). Para o ATP (Figura 6), pode-se observar que os parâmetros cinéticos são similares aos descritos para a enzima associada à membrana e solubilizada com Triton X-100 ou polidocanol, obtida de placas ósseas de rato (Pizauro et al., 1987; Ciancaglini et al., 1990a) e para a enzima ligada à membrana de culturas de células de osso alveolar humano (Simão et al., 2007b), apresentando uma pequena diferença na constante de afinidade. Efeitos cooperativos não foram observados, ao contrário do relatado para a enzima associada à membrana obtida de placas ósseas de rato (Pizauro et al., 1987; Demenis e Leone, 2000). Finalmente, quando $\mathrm{PP}_{\mathrm{i}}$ foi utilizado como substrato (Figura 6), foi observado um menor efeito cooperativo positivo do que o relatado para a enzima associada à membrana obtida de culturas de células de osso alveolar humano (Simão et al., 2007b) e placas ósseas de rato (Ciancaglini et al., 1990a). Enquanto a eficiência enzimática $\left(\mathrm{k}_{\mathrm{cat}} / \mathrm{K}_{0,5}\right)$ manteve-se comparável para a hidrólise de ATP e $\mathrm{PP}_{\mathrm{i}}$ pela enzima associada à membrana, o valor de $\left(\mathrm{k}_{\mathrm{cat}} / \mathrm{K}_{0,5}\right)$ aumentou cerca de 100 vezes quando PNFF foi usado como substrato. Estes dados sugerem 


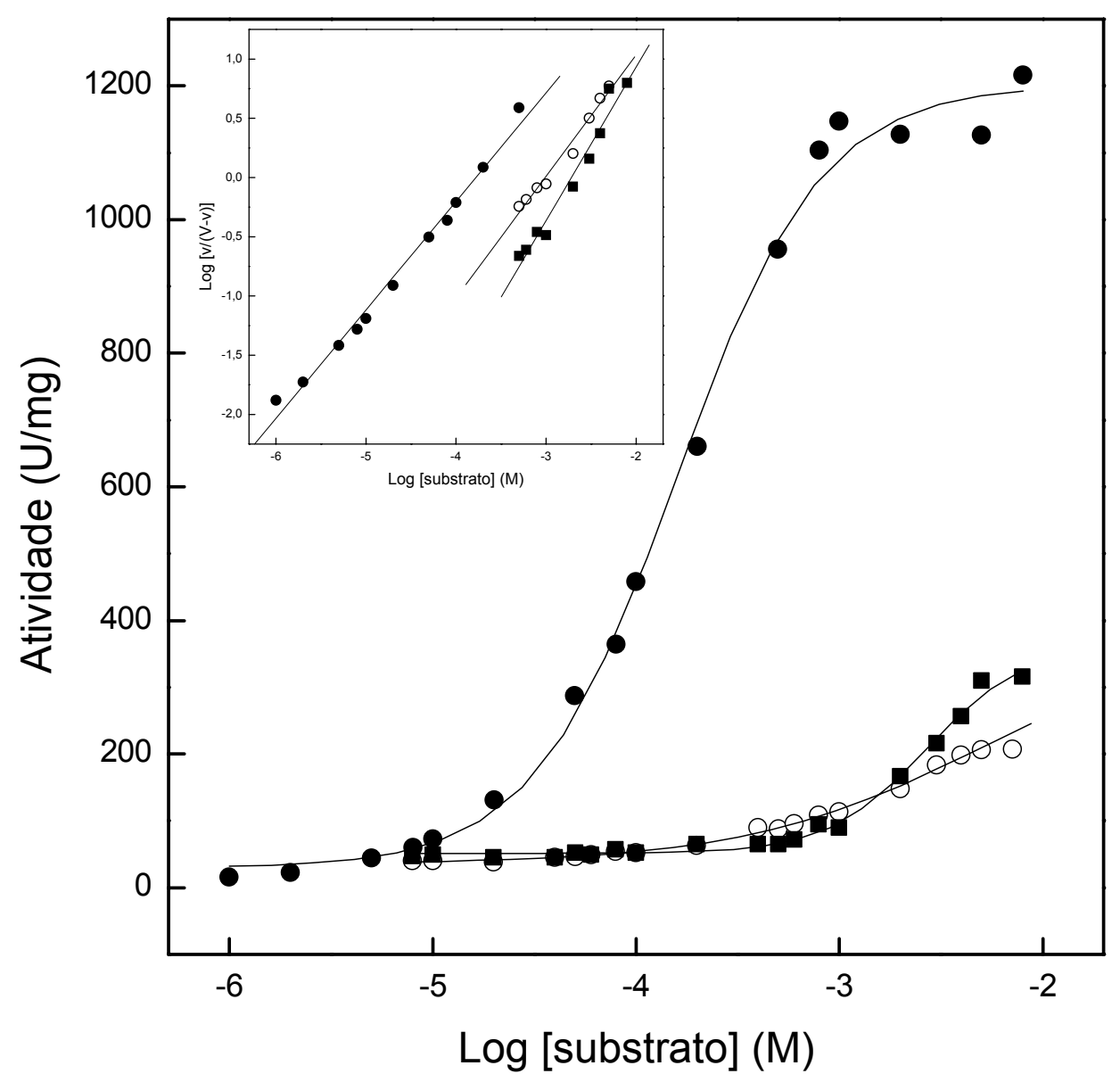

Figura 6. Efeito da concentração de (๑) PNFF, (O) ATP e (ם) $\mathrm{PP}_{\mathrm{i}}$ na atividade enzimática da fosfatase alcalina associada à membrana. As reações foram efetuadas em tampão AMPOL 50 mM, pH 10, pH 9,5 e pH 9,0 para PNFF, ATP e $\mathrm{PP}_{\mathrm{i}}$, respectivamente, contendo $\mathrm{MgCl}_{2} 2 \mathrm{mM}$ e substrato. As atividades PNFFase, ATPase e PPase foram determinadas conforme descrito nos itens 3.5, 3.6 e 3.7, respectivamente, de Material e Métodos, variando-se a concentração de substrato no meio, e as reações foram iniciadas pela adição da fração de membrana aos meios reacionais. Inserção: representação de Hill para a interação dos substratos com a enzima. 
que a eficiência catalítica da enzima pode ser fortemente afetada por moléculas associadas a ela.

Tabela 3. Parâmetros cinéticos obtidos para a hidrólise de PNFF, ATP e PPi pela fosfatase alcalina associada à membrana e reconstituída em lipossomos de diferentes composições lipídicas.

\begin{tabular}{|c|c|c|c|c|c|c|c|}
\hline \multirow[b]{2}{*}{ Substratos } & \multirow{2}{*}{$\begin{array}{l}\text { Parâmetros } \\
\text { cinéticos }\end{array}$} & \multirow{2}{*}{$\begin{array}{l}\text { Fração de } \\
\text { membrana }\end{array}$} & \multicolumn{5}{|c|}{ Proteolipossomos } \\
\hline & & & DPPC & $\begin{array}{c}\text { DPPC:DPPS } \\
(9: 1)\end{array}$ & $\begin{array}{c}\text { DPPC:DPPS } \\
(8: 2)\end{array}$ & $\begin{array}{c}\text { DPPC:DODAB } \\
(9: 1)\end{array}$ & $\begin{array}{c}\text { DPPC:DODAB } \\
(8: 2)\end{array}$ \\
\hline \multirow{4}{*}{ PNFF } & $\mathrm{V}_{\mathrm{m}}(\mathrm{U} / \mathrm{mg})$ & 1201,7 & 4571,1 & 3443,3 & 3986,2 & 5259,0 & 5064,7 \\
\hline & $\mathrm{K}_{0,5}(\mathrm{mM})$ & 0,16 & 0,17 & 0,20 & 0,27 & 0,14 & 0,19 \\
\hline & $\mathrm{n}$ & 0,9 & 1,0 & 1,0 & 1,0 & 0,94 & 0,9 \\
\hline & $\mathrm{k}_{\mathrm{cat}} / \mathrm{K}_{0,5}\left(\mathrm{M}^{-1} \cdot \mathrm{s}^{-1}\right)$ & $1,5 \times 10^{4}$ & $5,4 \times 10^{4}$ & $3,4 \times 10^{4}$ & $3,0 \times 10^{4}$ & $7,5 \times 10^{4}$ & $5,3 \times 10^{4}$ \\
\hline \multirow{4}{*}{ ATP } & $\mathrm{V}_{\mathrm{m}}(\mathrm{U} / \mathrm{mg})$ & 240,8 & 1236,9 & 511,6 & 562,5 & 960,1 & 817,9 \\
\hline & $\mathrm{K}_{0,5}(\mathrm{mM})$ & 1,5 & 1,4 & 1,3 & 1,5 & 0,23 & 1,1 \\
\hline & $\mathrm{n}$ & 1,0 & 1,2 & 4,2 & 1,7 & 1,0 & 0,93 \\
\hline & $\mathrm{k}_{\mathrm{cat}} / \mathrm{K}_{0,5}\left(\mathrm{M}^{-1} \cdot \mathrm{s}^{-1}\right)$ & $3,2 \times 10^{2}$ & $1,8 \times 10^{3}$ & $7,9 \times 10^{2}$ & $7,5 \times 10^{2}$ & $8,3 \times 10^{3}$ & $1,5 \times 10^{3}$ \\
\hline \multirow{4}{*}{$\mathbf{P P}_{\mathbf{i}}$} & $\mathrm{V}_{\mathrm{m}}(\mathrm{U} / \mathrm{mg})$ & 365,5 & 690,7 & 653,7 & 738,1 & 896,4 & 1340,3 \\
\hline & $\mathrm{K}_{0,5}(\mathrm{mM})$ & 2,7 & 2,0 & 2,1 & 2,1 & 1,6 & 2,0 \\
\hline & $\mathrm{n}$ & 1,3 & 4,9 & 4,6 & 6,7 & 5,8 & 5,0 \\
\hline & $\mathrm{k}_{\mathrm{cat}} / \mathrm{K}_{0,5}\left(\mathrm{M}^{-1} \cdot \mathrm{s}^{-1}\right)$ & $2,7 \times 10^{2}$ & $6,9 \times 10^{2}$ & $6,2 \times 10^{2}$ & $7,0 \times 10^{2}$ & $1,1 \times 10^{3}$ & $1,3 \times 10^{3}$ \\
\hline
\end{tabular}

\subsection{Solubilização da fosfatase alcalina}

Um dos métodos para se obter a enzima com a estrutura da âncora de fosfatidilinositol intacta é a solubilização da enzima com detergente, e entre os mais empregados estão o Triton X-100, polidocanol, entre outros (Pizauro et al., 1987; Ciancaglini et al., 1990a; lerardi et al., 2002; Camolezi et al., 2002, Simão et al., $2007 a, b)$. Com o objetivo de se padronizar a solubilização da fosfatase alcalina obtida a partir de culturas de células osteoblásticas, foram realizados dois tratamentos distintos: um com polidocanol (detergente neutro) e outro com fosfolipase.

O tratamento com polidocanol (detergente neutro) solubiliza as proteínas presentes na membrana, enquanto o tratamento com fosfolipase $\mathrm{C}$ cliva seletivamente a âncora de fosfatidilinositol de proteínas ancoradas (Low e Finean, 1978; Low et al., 1986; Hawrylak e Stinson, 1987; Ferguson et al., 1988; Pizauro et 
al., 1994, 1995; Ciancaglini et al., 1989; Camolezi et al., 2002). Os diferentes tratamentos realizados para a obtenção da enzima na forma solúvel, pela retirada da proteína da membrana, resultam em diferentes quebras na molécula, o que resultará em enzimas livres com diferentes constituintes.

A solubilização da enzima associada à membrana com fosfolipase $C$ foi avaliada empregando-se diferentes concentrações de proteína total e diferentes proporções de fosfolipase, e os melhores resultados foram obtidos incubando-se a fração de membrana com fosfolipase C de Bacillus thuringiensis (PIPLC) na proporção de $1 \mathrm{mg} / \mathrm{mL}$ de proteína total com 0,2 unidades de fosfolipase $/ \mathrm{mL}$, a $37^{\circ} \mathrm{C}$. De acordo com Pizauro e colaboradores (1995), a obtenção da fosfatase alcalina de placas ósseas nestas condições é realizada com 2 horas de incubação e 0,1 unidades de PIPLC, mas no presente trabalho, quase toda a enzima foi solubilizada (cerca de 93\%) com apenas 1 hora de incubação, apesar da necessidade de maior quantidade de PIPLC. Além disso, a enzima assim obtida apresentou uma atividade específica relativamente maior (Tabela 4).

Tabela 4. Efeito de diferentes tratamentos na solubilização da fração de membrana rica em fosfatase alcalina obtida a partir de células osteoblásticas cultivadas por 14 dias. A fração de membrana foi tratada com PIPLC e com polidocanol conforme descrito em Material e Métodos. A atividade PNFFase foi determinada conforme descrito no item 3.5 de Material e Métodos.

\begin{tabular}{llcc}
\hline \multirow{2}{*}{ Tratamento } & \multirow{2}{*}{ Amostras } & \multicolumn{2}{c}{ Atividade PNFFase } \\
\cline { 3 - 4 } & & $\mathbf{( U / m L )}$ & $\mathbf{( \% )}$ \\
\hline \multirow{2}{*}{ PIPLC } & Pellet & 102,9 & 9,0 \\
& Sobrenadante & $1.050,5$ & 92,5 \\
\hline \multirow{2}{*}{ Polidocanol } & Pellet & 114,5 & 8,9 \\
& Sobrenadante & $1.209,1$ & 94,0 \\
\hline
\end{tabular}

O efeito do tempo de incubação na solubilização da fosfatase alcalina com polidocanol $1 \%(p / v)$ é mostrado na Figura $7 A$. Observa-se que a quantidade de enzima solubilizada permanece praticamente constante ao longo do tempo, com cerca de $94 \%$ da atividade PNFFase liberada no sobrenadante, indicando 


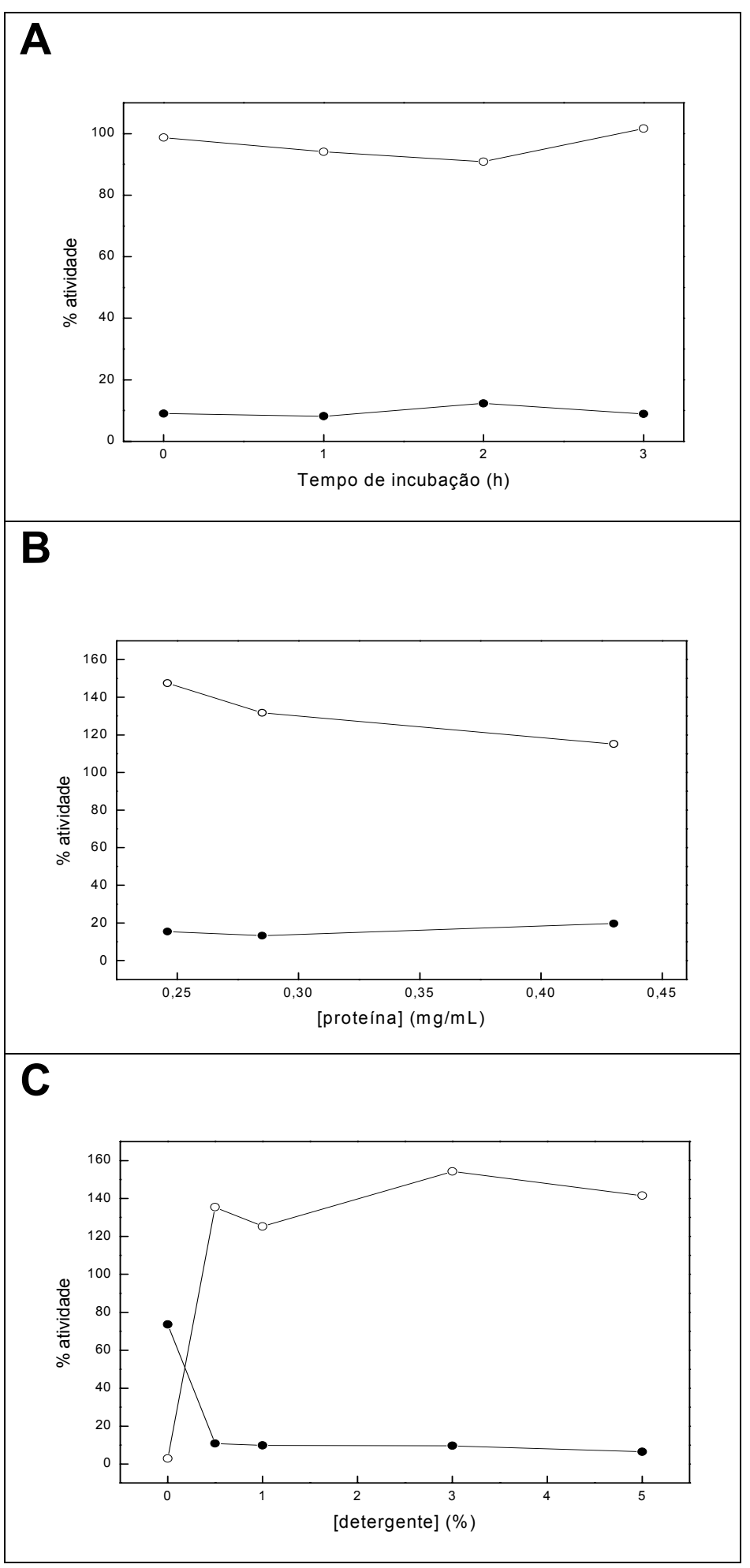

Figura 7. Padronização das condições ótimas de solubilização da fosfatase alcalina de membrana com detergente. (A) Efeito do tempo de incubação da fração de membrana $(0,2 \mathrm{mg} / \mathrm{mL}) \mathrm{com}$ polidocanol $1 \%(\mathrm{p} / \mathrm{v}) ;(\mathbf{B})$ efeito da concentração de proteína total na solubilização da fosfatase alcalina com polidocanol $1 \%(p / v)$ e (C) efeito da concentração de polidocanol na solubilização da enzima. (O) Enzima solubilizada e $(\mathbf{O})$ pellet (enzima que permanece associada à membrana). A fração de membrana foi incubada a $25^{\circ} \mathrm{C}$ com o detergente e a atividade PNFFase foi determinada conforme descrito no item 3.5 de Material e Métodos. 
solubilização instantânea da enzima. Este tratamento é o mais rápido quando comparado com os demais empregados no presente trabalho.

A influência da concentração de proteína total presente na fração de membrana na solubilização instantânea da fosfatase alcalina com polidocanol $1 \%$ $(\mathrm{p} / \mathrm{v})$ está mostrada nas Figuras 7B e 8A. Observa-se uma eficiência máxima para a solubilização na presença de cerca de $0,2 \mathrm{mg} / \mathrm{mL}$ de proteína, com ativação da atividade PNFFase da enzima solubilizada (Figura 7B), enquanto na Figura 8A observa-se que nesta concentração de proteína total, cerca de $35 \%$ das proteínas da membrana são solubilizadas.

O efeito da concentração do detergente na solubilização instantânea da fosfatase alcalina de membrana está mostrado nas Figuras 7C e 8B. Os melhores resultados para uma solubilização máxima tanto em relação à atividade PNFFase quanto em relação à quantidade de proteína solubilizada, sem a necessidade da utilização de excesso de detergente, foram obtidos com uma concentração de polidocanol de $1 \%(p / v)$.

Assim, a padronização das condições ótimas de solubilização da fosfatase alcalina empregando-se polidocanol, demonstrou solubilização instantânea da enzima, com uma concentração em proteína total presente na fração de membrana de $0,2 \mathrm{mg} / \mathrm{mL}$, quando o detergente foi utilizado em uma concentração final de $1 \%$ $(\mathrm{p} / \mathrm{v})$, e apresentando cerca de $94 \%$ da atividade PNFFase presente no sobrenadante, o que corresponde a uma relação proteína:detergente de 1:40 (em peso) (Tabela 4). Esta redução no tempo de incubação da fração de membrana com o detergente, quando comparada com outras metodologias utilizadas para a solubilização de fosfatases alcalinas (Pizauro et al., 1987; Ciancaglini et al., 1990a; lerardi et al., 2002; Camolezi et al., 2002), é importante na medida em que contribui para um menor efeito desnaturante na enzima. Observa-se ainda que a enzima solubilizada apresenta uma atividade específica 3,8 vezes maior que a da enzima associada à membrana (Tabela 5), e este estímulo da atividade enzimática com a solubilização também foi observado para a fosfatase alcalina obtida de placas ósseas de rato (Ciancaglini et al., 1990). Além disso, a análise de proteína revelou que apenas $35 \%$ da proteína total está presente na fração solubilizada, portanto, de todas as proteínas existentes na membrana dos osteoblastos, a fosfatase alcalina não é o maior componente protéico, ao contrário dos resultados obtidos por Pizauro e colaboradores (1987) para a fosfatase alcalina de placas ósseas, que relataram 


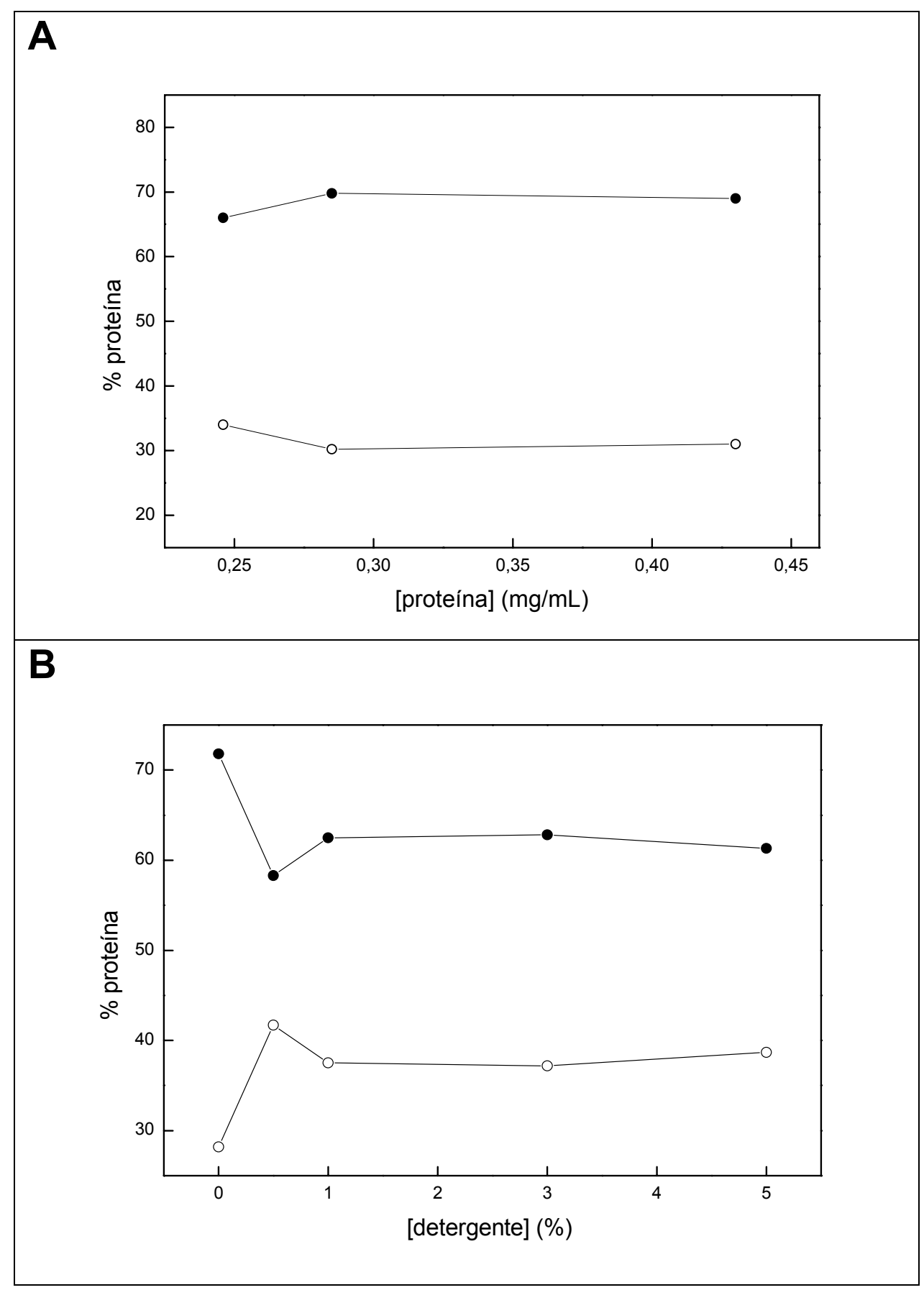

Figura 8. Padronização das condições ótimas de solubilização da fosfatase alcalina de membrana com detergente. (A) Efeito da concentração de proteína total na solubilização da fosfatase alcalina de membrana com polidocanol $1 \%(p / v)$ e (B) efeito da concentração de polidocanol na solubilização da enzima. (O) Enzima solubilizada e $(\bullet)$ pellet (enzima que permanece associada à membrana). A fração de membrana foi incubada a $25^{\circ} \mathrm{C}$ com o detergente e a concentração de proteína foi determinada conforme descrito no item 3.4 de Material e Métodos. 
que a enzima é o maior componente protéico daquela membrana.

Tabela 5. Solubilização instantânea da fosfatase alcalina de membrana (F.A.M.), obtida de culturas de células osteoblásticas, com polidocanol $1 \%(p / v)$.

\begin{tabular}{lccccc}
\hline \multicolumn{1}{c}{ Etapa } & $\begin{array}{c}\text { Volume } \\
(\mathbf{m L})\end{array}$ & $\begin{array}{c}\text { Proteína } \\
(\mu \mathbf{g} / \mathbf{m L})\end{array}$ & U/mg & $\begin{array}{c}\text { Recuperação } \\
\mathbf{( \% )}\end{array}$ & Fator \\
\hline F.A.M. & 4,0 & 200,0 & 1201,7 & 100 & 1 \\
Pellet & 4,0 & 177,0 & 146,6 & 11 & 0,12 \\
Sobrenadante & 4,0 & 87,4 & 4593,7 & 167 & 3,8 \\
\hline
\end{tabular}

As frações solubilizadas tanto com PIPLC quanto com polidocanol foram submetidas à eletroforese em gel de poliacrilamida $(7 \%)$ e revelaram vários contaminantes protéicos (resultados não mostrados), entretanto somente uma banda com atividade de fosfomonohidrolase (Figura 5B), com massa molecular de aproximadamente $120 \mathrm{kDa}$, o que reforça que esta enzima é um homodímero constituído de duas subunidades aparentemente idênticas, cada uma com massa molecular de 60 kDa, como descrito por muitos autores (Ciancaglini et al., 1990a; Pizauro et al., 1995; Simão et al., 2007a,b).

Uma vez padronizada a solubilização da fosfatase alcalina de membrana, foram realizados vários experimentos na tentativa de se purificar a enzima, mas os diversos protocolos utilizados se mostraram ineficientes na separação dos diferentes componentes protéicos do extrato bruto solubilizado. Diante das dificuldades encontradas na purificação da fosfatase alcalina por métodos convencionais, foi testada uma estratégia mais rápida: como o polidocanol favorece uma solubilização parcialmente seletiva da enzima, resultando no enriquecimento do extrato bruto solubilizado com fosfatase alcalina, optou-se por retirar o excesso de detergente (abaixo de sua CMC), empregando-se a resina Calbiosorb e, em seguida, incubar a solução protéica com uma suspensão de lipossomos previamente formados.

Entre os processos de obtenção da enzima na sua forma solúvel, o tratamento com detergente é o único que resulta na obtenção da enzima com sua estrutura protéica e da âncora intactas. Entretanto, é necessária a remoção do detergente empregado na solubilização da enzima antes de sua reconstituição em lipossomos, uma vez que seria difícil qualquer tipo de estudo de incorporação na 
presença de detergente, mesmo em baixa concentração.

Assim, foram realizados estudos com a resina Calbiosorb, já descrita na literatura por sua eficiência na remoção de polidocanol de fosfatase alcalina de placas ósseas solubilizada com este detergente (Camolezi et al., 2002). Várias proporções de resina, bem como diferentes tempos de incubação foram avaliados, mas a remoção do detergente do extrato bruto solubilizado com polidocanol só foi eficiente quando o extrato foi incubado durante 2 horas com a resina na proporção de $200 \mathrm{mg} / \mathrm{mL}$, a $4^{\circ} \mathrm{C}$.

Para garantir que a resina tenha removido eficientemente todo o detergente, amostras de extrato de clorofórmio de polidocanol, de enzima solubilizada com polidocanol e de enzima solubilizada e tratada com Calbiosorb foram analisadas por RMN (Figura 9). Como pode ser observado na Figura C, os picos característicos do polidocanol, indicando a presença de radicais $\left(-\mathrm{CH}_{2-}\right)$ da cadeia lauril, próximos de $1,2 \mathrm{ppm}$, e do radical (-O- $\left.\mathrm{CH}_{2}-\mathrm{CH}_{2}-\mathrm{O}-\right)$, em torno de 3,5 ppm, desapareceram completamente. Assim, os estudos de incorporação prosseguiram com o extrato bruto solubilizado e livre de detergente.

\section{$\mathrm{CH}_{3}\left(\mathrm{CH}_{2}\right)_{11}-\mathrm{O}-\left(\mathrm{CH}_{2} \mathrm{CH}_{2} \mathrm{O}\right)_{9} \mathrm{H}$}

\section{Estrutura do polioxietileno-9-lauril éter (polidocanol)}

\subsection{Reconstituição da fosfatase alcalina em lipossomos e caracterização cinética dos sistemas de proteolipossomos}

Para se obter um eficiente sistema que mimetize as vesículas da matriz, é essencial estudar as melhores condições necessárias para a otimização da incorporação da fosfatase alcalina em lipossomos, de modo a se obter um máximo de incorporação da enzima às vesículas com mínima perda em atividade, o que envolve conhecimento dos lipídios ou misturas de lipídios mais adequados para a reconstituição em termos do tipo do grupo cabeça polar, carga, comprimento da cadeia hidrocarbônica e tamanho das vesículas formadas.

Assim, diante das dificuldades encontradas nas diversas tentativas de purificação da fosfatase alcalina por métodos convencionais, os primeiros estudos de incorporação prosseguiram apenas com o extrato bruto solubilizado com polidocanol e livre de detergente.

Os estudos iniciais de obtenção de proteolipossomos foram realizados com o 


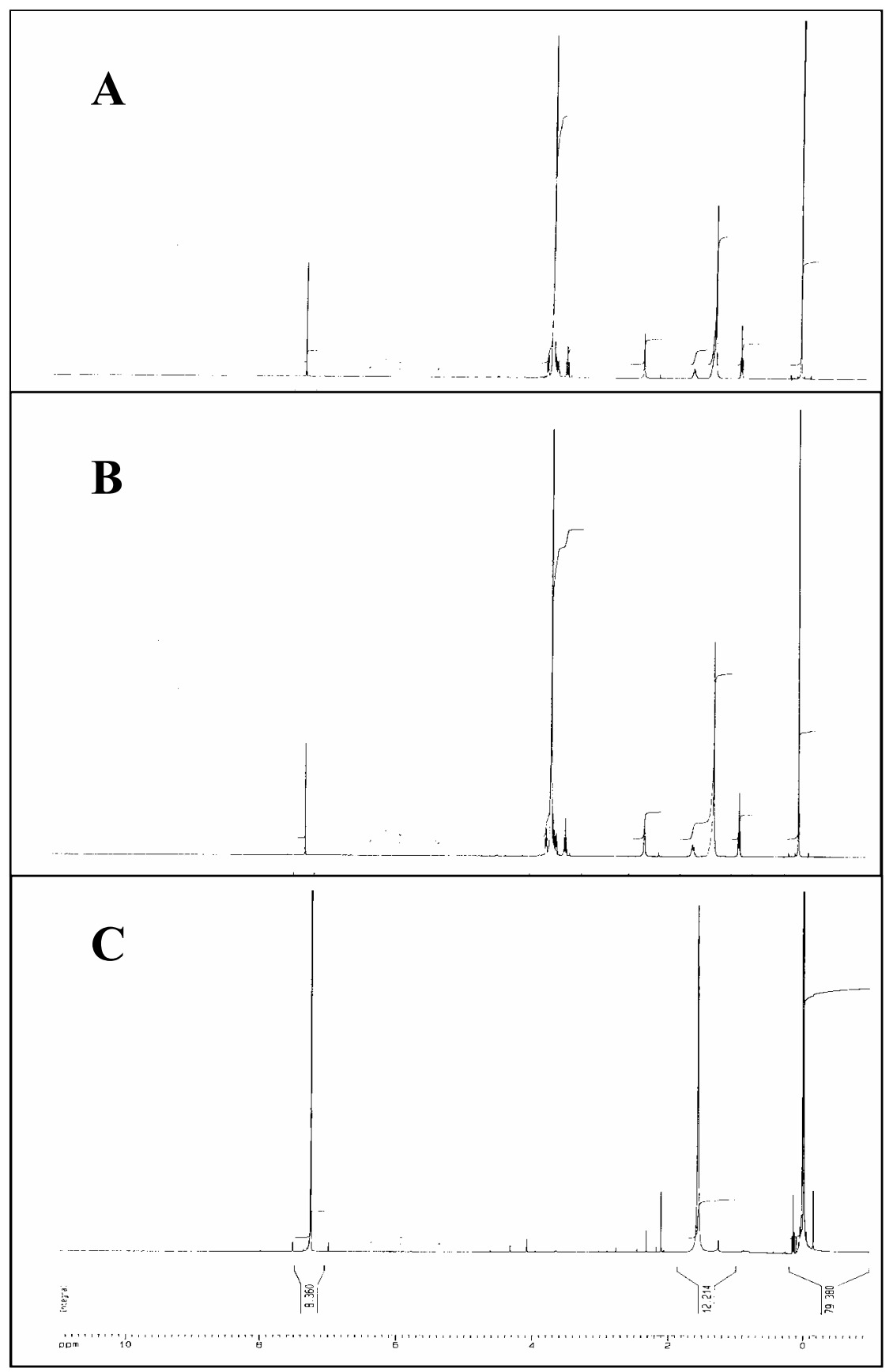

Figura 9. Remoção do excesso de detergente do extrato bruto solubilizado. Espectros de RMN para os extratos de clorofórmio de (A) solução de polidocanol 1\% $(\mathrm{p} / \mathrm{v})$, (B) fosfatase alcalina solubilizada com polidocanol 1\% (p/v) e (C) fosfatase alcalina solubilizada com polidocanol $1 \%(\mathrm{p} / \mathrm{v})$ e posteriormente tratada com a resina Calbiosorb na proporção de $200 \mathrm{mg} / \mathrm{mL}$, durante 2 horas, sob agitação constante, a $4^{\circ} \mathrm{C}$. Os extratos de clorofórmio para análise por RMN foram obtidos conforme descrito no item 3.15 de Material e Métodos. 
DPPC, que é um fosfolipídio comumente utilizado para a reconstituição de fosfatases alcalinas de diferentes fontes, bem como outras proteínas de membrana, em lipossomos (Angrand et al., 1997; Nosjean e Roux, 1999; Camolezi et al., 2002; Morandat et al., 2002, 2003; Daghastanli et al., 2004; Ronzon et al., 2004; de Lima Santos et al., 2005; Giocondi et al., 2007) e é frequentemente empregado em estudos de modelos de biomembranas (López Cascales et al., 2006; Giocondi et al., 2007).

O tamanho dos lipossomos constituídos por DPPC, determinado por espalhamento de luz dinâmico, revelou um diâmetro médio de cerca de 100 nm, que está próximo ao tamanho esperado para vesículas geradas pelo método de sonicação (New, 1990; Fleury et al., 1995; Prasad, 1996; Arien e Dupuy, 1997). Na Figura 10A é mostrada a estabilidade das soluções de lipossomos constituídos de DPPC. Como pode ser observado, os lipossomos são estáveis durante cerca de 20 dias após sua formação, quando armazenados a $4^{\circ} \mathrm{C}$.

$\mathrm{Na}$ Figura 11 pode ser observada a curva de incorporação da fosfatase alcalina, solubilizada com polidocanol e livre de detergente, aos lipossomos constituídos de DPPC, após a incubação do extrato bruto solubilizado com a resina Calbiosorb na proporção de $200 \mathrm{mg} / \mathrm{mL}$, por 2 horas, $4^{\circ} \mathrm{C}$. Assim, a padronização das condições ótimas para a reconstituição da fosfatase alcalina em lipossomos de DPPC, de modo a se obter um máximo de incorporação às vesículas com mínima perda em atividade, proporcionou máxima incorporação da atividade PNFFase da enzima (cerca de 90\%) quando lipossomos e proteína $(23 \mu \mathrm{g} / \mathrm{mL}$ ) foram incubados na proporção de $1: 1(\mathrm{v} / \mathrm{v})$, a $25^{\circ} \mathrm{C}$. Como pode ser observado, o processo de incorporação é tempo dependente e tem uma velocidade grande no início, atingindo valores máximos de incorporação com cerca de 40 minutos de incubação. Resultados semelhantes de incorporação foram obtidos por Camolezi e colaboradores (2002) na reconstituição de fosfatase alcalina de placas ósseas em lipossomos constituídos de DPPC, e por Angrand e colaboradores (1997), que empregaram uma metodologia de reconstituição de fosfatase alcalina de intestino bovino mediado por detergente.

O tamanho médio do sistema vesicular formado foi avaliado empregando-se a técnica de espalhamento de luz dinâmico. Os resultados obtidos revelaram vesículas com diâmetro médio de $200 \mathrm{~nm}$ e pouca dispersão da amostra. 


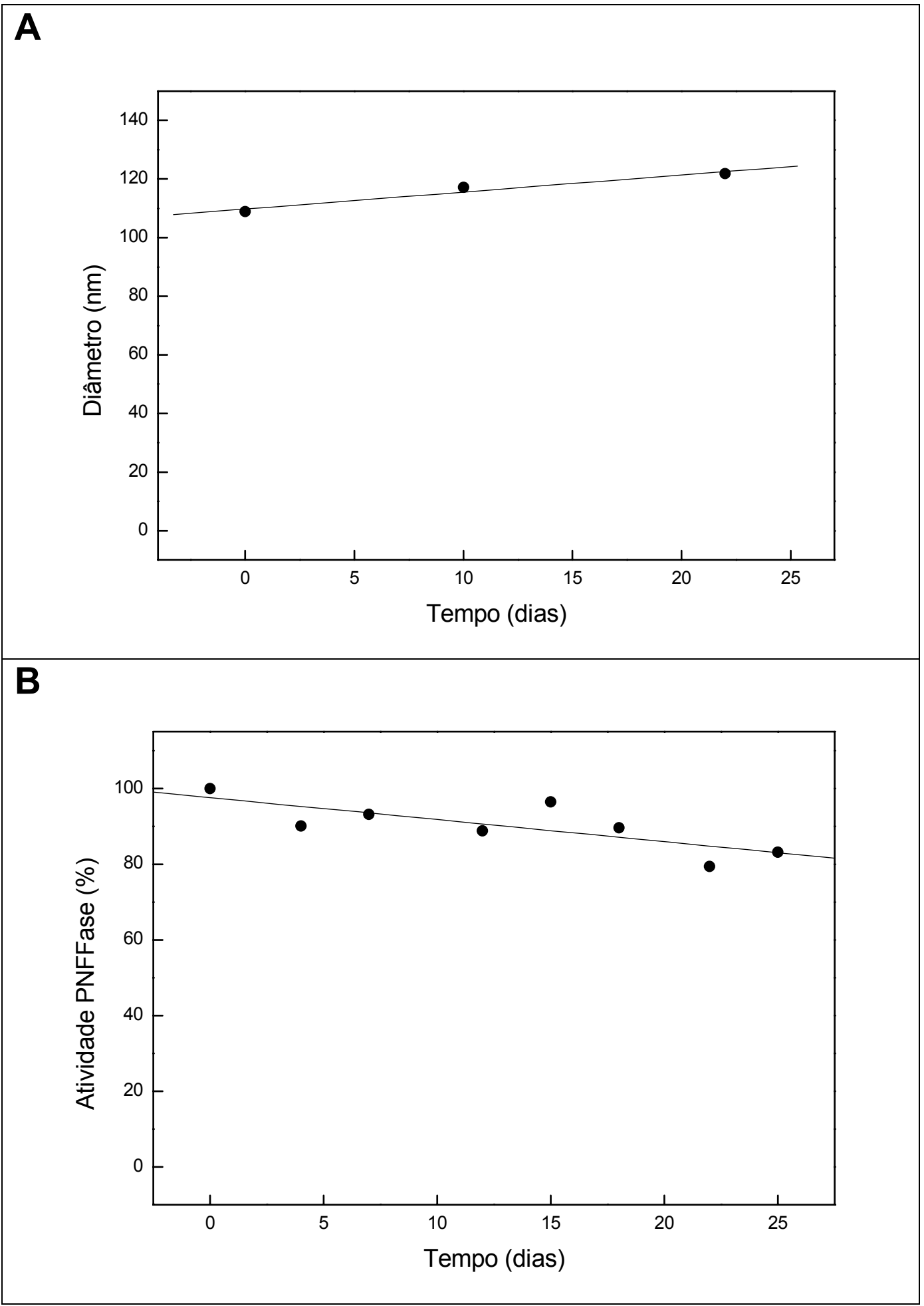

Figura 10. Estabilidade dos sistemas de (A) lipossomos constituídos de DPPC, acompanhada utilizando-se a técnica de espalhamento de luz dinâmico, e (B) fosfatase alcalina ancorada aos lipossomos, acompanhada através da medida da atividade PNFFase da enzima reconstituída. Ambos os sistemas foram armazenados a $4^{\circ} \mathrm{C}$. 


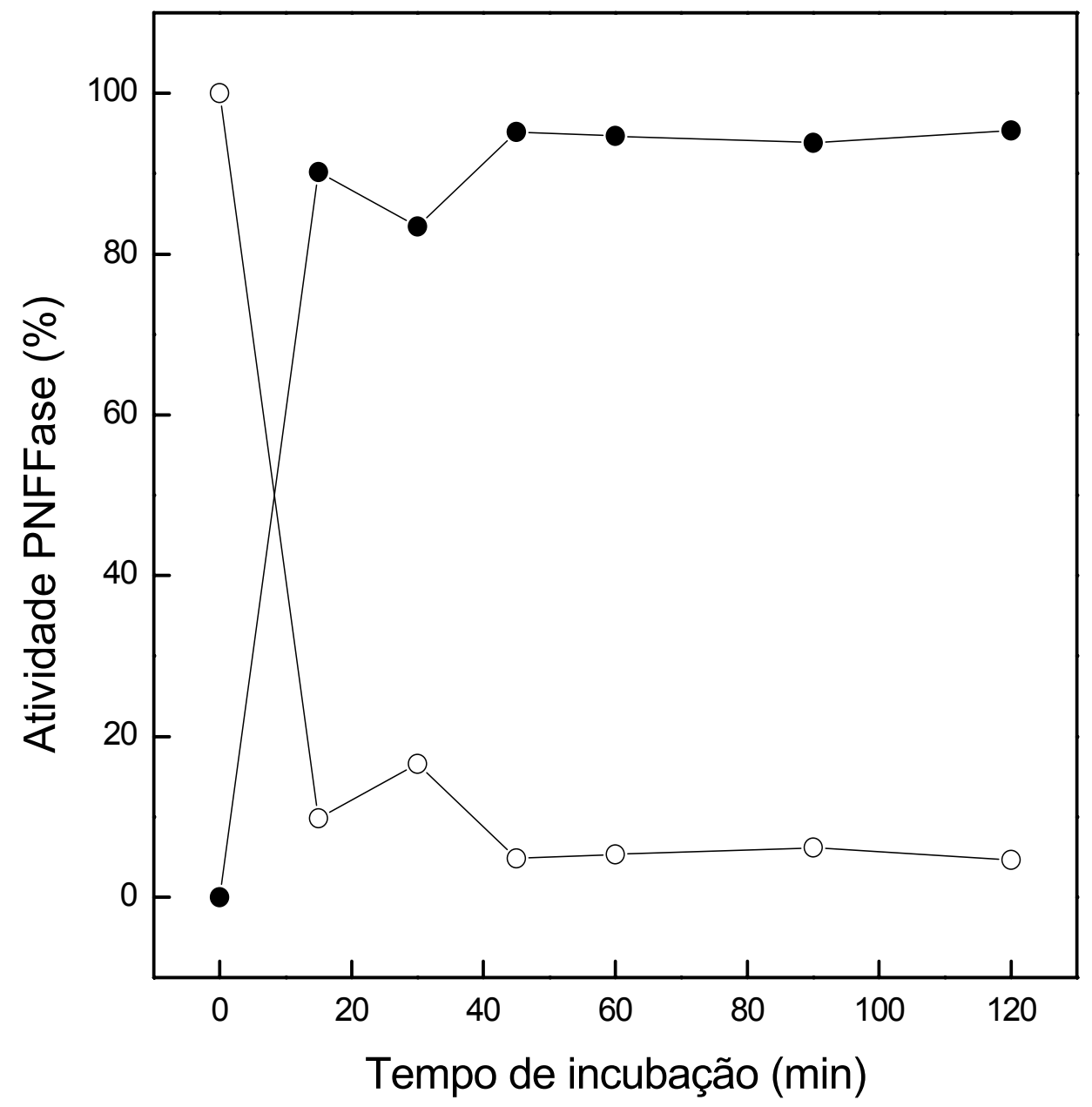

Figura 11. Incorporação da fosfatase alcalina em lipossomos constituídos de DPPC, após a incubação do extrato bruto solubilizado com a resina Calbiosorb na proporção de $200 \mathrm{mg} / \mathrm{mL}$, por 2 horas, a $4^{\circ} \mathrm{C}$. Lipossomos e enzima $(23 \mu \mathrm{g} / \mathrm{mL})$ foram incubados por 1 hora em tampão Tri-HCl $50 \mathrm{mM}, \mathrm{pH}$ 7,5, contendo $\mathrm{MgCl}_{2} 2$ $\mathrm{mM}$, a $25^{\circ} \mathrm{C}$ e alíquotas de $100 \mu \mathrm{L}$ foram retiradas e centrifugadas. A diminuição da atividade PNFFase no sobrenadante ou o aumento da mesma no pellet mostram que ocorreu a incorporação. (๑) Atividade PNFFase no pellet e $(O)$ atividade PNFFase no sobrenadante. 
$\mathrm{Na}$ Figura 10B pode ser observada a estabilidade da fosfatase alcalina ancorada aos lipossomos constituídos de DPPC, quando estocados a $4^{\circ} \mathrm{C}$. O sistema é relativamente estável quando armazenado a $4^{\circ} \mathrm{C}$. De fato, somente cerca de $10 \%$ da atividade PNFFase inicial da enzima foi perdida após 20 dias de armazenamento. A estabilidade da enzima associada aos lipossomos é semelhante à descrita para os sistemas de proteolipossomos obtidos por Camolezi e colaboradores (2002), com a reconstituição de fosfatase alcalina de placas ósseas em lipossomos constituídos de DPPC, armazenados a $4^{\circ} \mathrm{C}$. A estabilidade da enzima depende tanto da integridade do lipossomo como da manutenção da conformação nativa da enzima. A fosfatase alcalina é relativamente estável quando armazenada em temperaturas entre $25^{\circ} \mathrm{C}$ e $40^{\circ} \mathrm{C}$, mas é rapidamente desnaturada em temperaturas acima de $45^{\circ} \mathrm{C}$ (McComb et al., 1979; Curti et al., 1986). Além disso, o armazenamento de lipossomos em temperaturas acima da ambiente favorece a formação de agregados, podendo ocasionar a desnaturação da proteína por precipitação.

O proteolipossomo obtido foi tratado com hexano para a remoção do excesso de lipídios e submetido à eletroforese em gel de poliacrilamida $(7 \%)$ em condições desnaturantes, revelando somente uma banda com massa molecular de aproximadamente 60 kDa (Figura 12, gel 2). Uma banda bem suave, com cerca de $120 \mathrm{kDa}$, também pode ser observada no gel, muito provavelmente correspondendo a uma fração da fosfatase alcalina que não sofreu redução e permaneceu na forma dimérica. Este experimento reforça que esta enzima é um homodímero constituído de duas subunidades aparentemente idênticas, indicando também que o sistema formado incorporou apenas a fosfatase alcalina, sendo, portanto, constituído de uma única enzima. Para reforçar esta hipótese, uma amostra de proteolipossomos foi aplicada no gel, porém sem tratamento com mercapto etanol e também sem aquecimento, e após a corrida, revelada para atividade de fosfomonohidrolase. Nestas condições, apenas uma banda com aproximadamente 120 kDa (Figura 12, gel 3) pode ser visualizada, reforçando a presença de somente uma proteína e confirmando a viabilidade do procedimento, que apresenta alta eficiência de incorporação da proteína em um processo praticamente muito seletivo.

Amostras de lipossomos (Figura 13A) e de proteolipossomos (Figura 13B) também foram submetidas à microscopia eletrônica e pode ser observado que a reconstituição da enzima não altera a estrutura dos lipossomos de DPPC. 


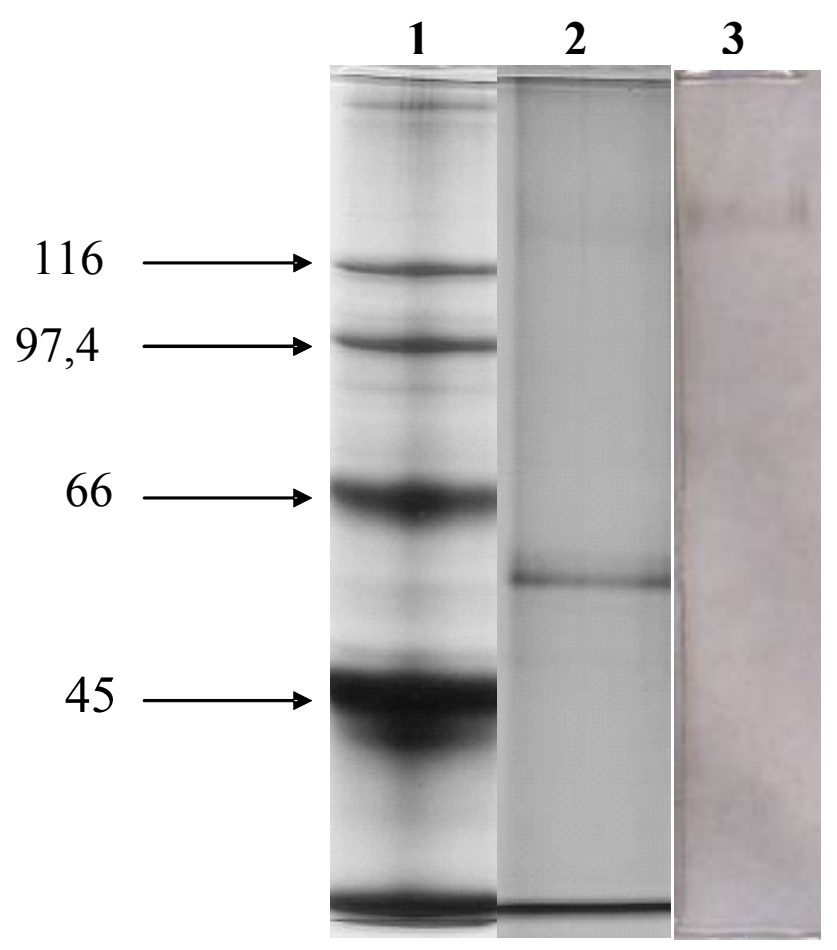

Figura 12. Eletroforese em condições desnaturantes de proteolipossomos constituídos de DPPC, realizada conforme descrito no item 3.21 de Material e Métodos, em um gel de poliacrilamida $7 \%$. As amostras foram previamente tratadas com n-hexano antes do procedimento normal para eletroforese. O gel foi revelado utilizando-se nitrato de prata ou renaturado com tampão Tris- $\mathrm{HCl} 50$ mM, pH 7,5 e revelado para atividade fosfomonohidrolítica. Gel 1: padrões de massa molecular; Gel 2: amostra de proteolipossomos constituídos de DPPC, revelada com nitrato de prata; Gel 3: amostra protéica não desnaturada de proteolipossomos constituídos de DPPC, revelada para atividade de fosfomonohidrolase. A atividade foi detectada em tampão AMPOL $50 \mathrm{mM}, \mathrm{pH}$ 10, contendo $\mathrm{MgCl}_{2} 2 \mathrm{mM}$, Fast Blue RR-salt 0,12\% (p/v) e $\alpha$-naftilfosfato $0,12 \%(p / v)$, a $37^{\circ} \mathrm{C}$. 


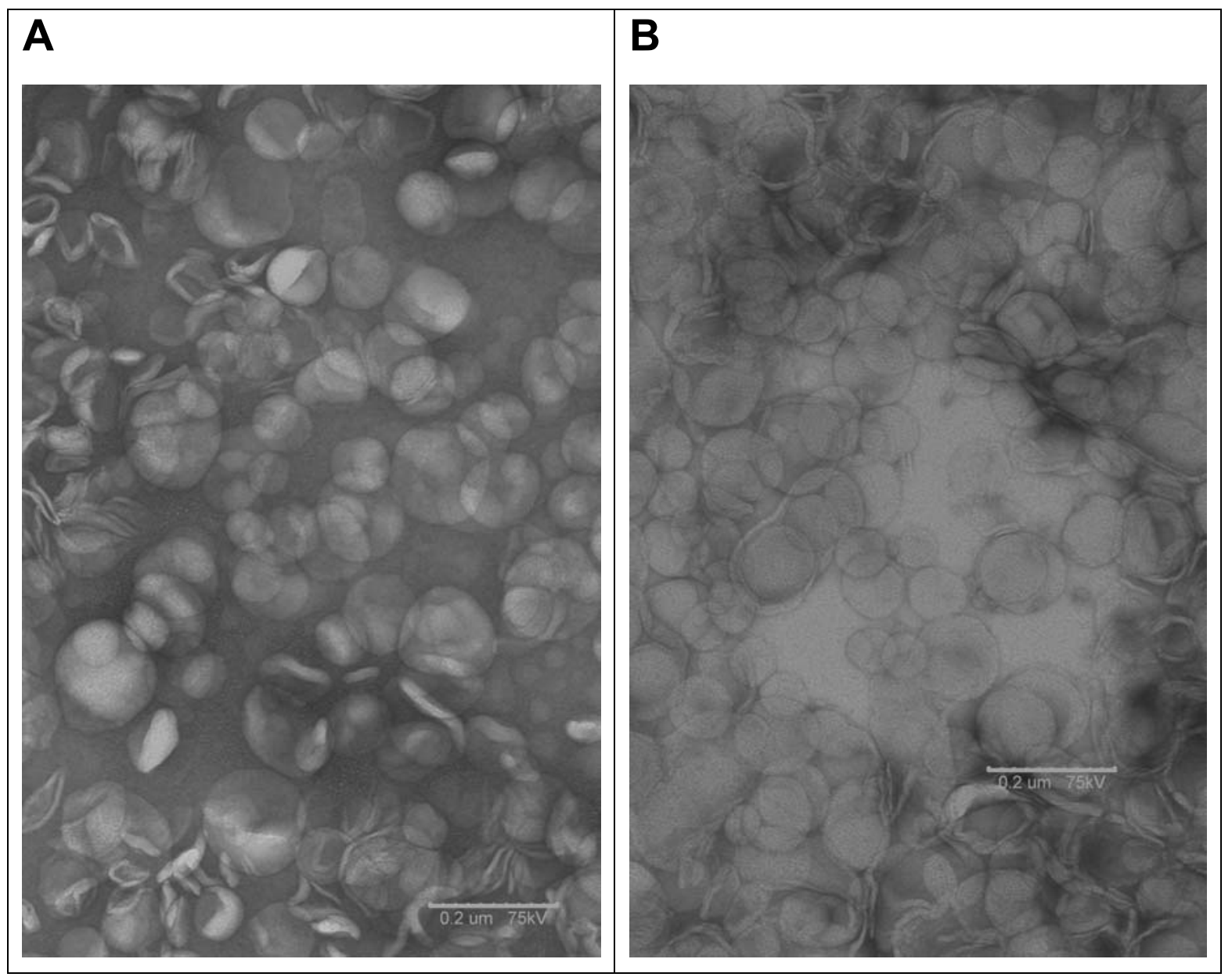

Figura 13. Microscopia eletrônica com marcação negativa de: (A) lipossomos constituídos de DPPC e (B) proteolipossomos com a fosfatase alcalina reconstituída, ambos com ampliação de 50x. As amostras foram preparadas e as imagens obtidas como descrito no item 3.18 de Material e Métodos. 
Assim, esta estratégia se revelou eficiente na obtenção de proteolipossomos ricos em fosfatase alcalina devido à inserção preferencial da âncora de GPI às bicamadas lipídicas, em detrimento das outras proteínas que não interagiram favoravelmente com os sistemas vesiculares, comprovando que a metodologia de reconstituição padronizada pode ser usada eficientemente na obtenção dos sistemas de proteolipossomos, sem a necessidade de se empregar etapas prévias de purificação da enzima solubilizada.

Uma vez padronizado o protocolo para a reconstituição da fosfatase alcalina em lipossomos de DPPC, foram realizados alguns experimentos com o objetivo de se verificar o tipo de interação que existe entre a enzima e os lipossomos.

Sabendo-se que o tratamento com fosfolipase C cliva seletivamente a âncora de fosfatidilinositol de proteínas ancoradas (Low e Finean, 1978; Low et al., 1986; Hawrylak e Stinson, 1987; Ferguson et al., 1988; Pizauro et al., 1994, 1995), uma amostra de proteolipossomos foi tratada com fosfolipase $\mathrm{C}$ de Bacillus thuringiensis (PIPLC) na proporção de $0,2 \mathrm{U}$ de $\mathrm{PIPLC} / \mathrm{mL}$ de suspensão, por 1 hora, à temperatura ambiente, e cerca de $60 \%$ da atividade de fosfomonohidrolase estava presente no sobrenadante. Este sobrenadante, quando submetido à eletroforese em gel de poliacrilamida (7\%), revelou somente uma banda com atividade de fosfomonohidrolase com massa molecular de aproximadamente $120 \mathrm{kDa}$ (resultados não mostrados). Este resultado de liberação da enzima reforça a hipótese de que a fosfatase alcalina está interagindo com os lipossomos exclusivamente pela âncora de fosfatidilinositol, conforme demonstrado anteriormente por Camolezi e colaboradores (2002), mesmo empregando-se na reconstituição uma mistura de proteínas obtidas, isto é, sem prévia purificação da enzima. Além disso, segundo estes autores, a liberação da enzima dos lipossomos é dependente tanto do tempo de incubação quanto da concentração de fosfolipase empregada.

Uma vez que com os experimentos mostrados até o momento fica evidente a presença de apenas uma entidade protéica incorporada a estes sistemas, este protocolo de obtenção de proteolipossomos foi utilizado também para a avaliação dos efeitos de lipossomos constituídos por lipídios com diferentes cargas, em diferentes proporções, na capacidade tanto de inserção da enzima aos sistemas vesiculares, bem como de modulação da atividade da enzima reconstituída pelos diferentes sistemas. Para tanto, os estudos foram realizados empregando-se um lipídio com carga negativa (DPPS) e um com carga positiva (DODAB), utilizando-se 
lipossomos mistos constituídos de DPPC:DPPS e DPPC:DODAB, ambos nas proporções 9:1 e 8:2 (razão molar).

Brometo de dioctadecildimetilamônio (DODAB) foi uma das primeiras moléculas anfifílicas catiônicas sintetizadas (Kunitake et al., 1977) e possui duas longas cadeias hidrocarbônicas com 18 carbonos, todos saturados. Ultimamente, vem sendo muito utilizado na composição de lipossomos constituídos tanto de DODAB puro, bem como lipossomos mistos, com o objetivo de se estudar suas propriedades físico-químicas (Benatti et al., 2001, 2007).

O DPPS é um dos principais lipídios encontrados nas membranas das vesículas da matriz e estudos vêm demonstrando que tem uma importante função no processo de biomineralização, regulando tanto a entrada de cálcio para o interior das vesículas, como também a formação do cristal de hidroxiapatita (Kirsch et al., 1997; Wu et al., 1997, 2002; Damek-Poprawa et al., 2006).

A carga do lipídio pode ter um papel fundamental na interação de proteínas com lipídios (Liu et al., 1999; Bellet-Amalric et al., 2000; Ronzon et al., 2002) e, consequentemente, com membranas biológicas. Ronzon e colaboradores (2002) demonstraram que a fosfatase alcalina de intestino bovino interage de diferentes modos com monocamadas constituídas de DPPC ou DPPS quando inserida nos filmes lipídicos e acarreta efeitos diferentes sobre a organização destes microambientes, dependendo da composição lipídica onde a enzima se encontra, comprovando que a natureza do lipídio tem grande influência nas interações lipídioproteína.

A composição e a fluidez da bicamada lipídica também podem influenciar a estrutura protéica, com maiores temperaturas aumentando a fluidez da bicamada, podendo ocasionar mudanças conformacionais na estrutura da proteína, com conseqüente alteração da atividade da enzima (New, 1990; Engberts e Hoekstra, 1995).

Assim, os tamanhos dos lipossomos mistos constituídos por DPPC:DPPS (9:1), DPPC:DPPS (8:2), DPPC:DODAB (9:1) e DPPC:DODAB (8:2), determinados por espalhamento de luz dinâmico, foram 85, 100, 140 e 170 nm, respectivamente, próximos ao tamanho esperado para vesículas geradas pelo método de sonicação (New, 1990; Fleury et al., 1995; Prasad, 1996; Arien e Dupuy, 1997).

A estabilidade das soluções de lipossomos constituídos de DPPC:DPPS pode ser observada na Figura 14. Os lipossomos são estáveis durante cerca de 20 dias 


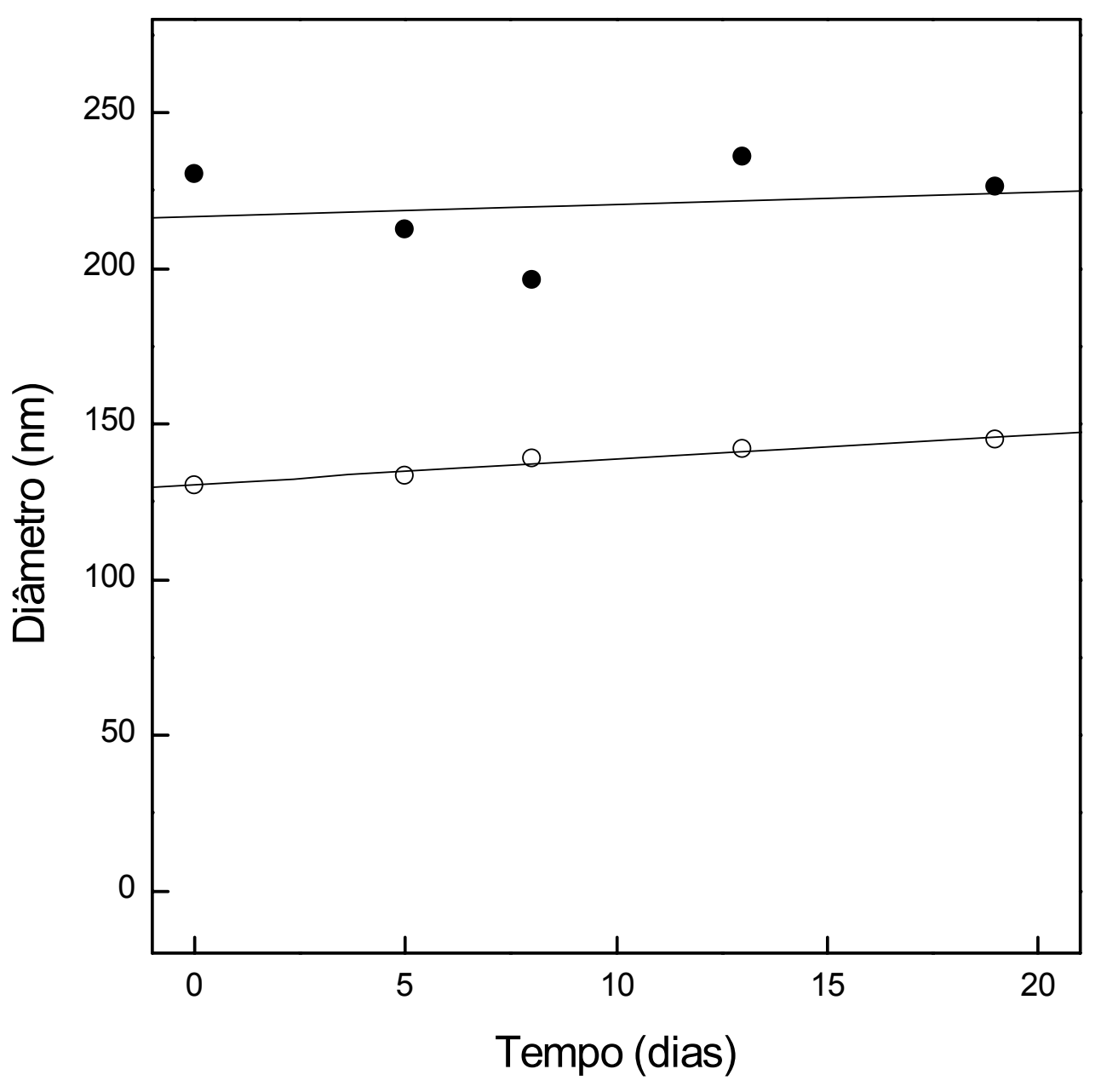

Figura 14. Estabilidade dos lipossomos mistos constituídos de (๑) DPPC:DPPS (9:1) e (O) DPPC:DPPS (8:2), armazenados a $4^{\circ} \mathrm{C}$, e acompanhada utilizando-se a técnica de espalhamento de luz dinâmico. 
após sua formação, quando armazenados a $4^{\circ} \mathrm{C}$. Os lipossomos constituídos de DPPC:DODAB, por sua vez, são relativamente instáveis, mesmo quando armazenados a $4^{\circ} \mathrm{C}$, sendo portanto utilizados no máximo uma semana após sua preparação (resultados não mostrados).

Considerando-se o tamanho físico das vesículas da matriz naturais, com diâmetros variáveis de 20 a 300 nm, há as hipóteses de que mais de um tipo de vesícula da matriz poderia existir ou, ainda, o tamanho observado poderia depender da técnica de extração utilizada. Além disso, ainda não se sabe ao certo se múltiplas subclasses de vesículas da matriz são produzidas por uma única célula em um estágio específico de diferenciação ou se cada célula produz apenas uma classe de vesículas da matriz (Hsu e Anderson, 1978; Sela et al., 2000).

Nas Figuras 15A, 15B, 15C e 15D são mostradas as curvas de incorporação da fosfatase alcalina aos lipossomos mistos constituídos de DPPC:DPPS (9:1), DPPC:DPPS (8:2), DPPC:DODAB (9:1) e DPPC:DODAB (8:2), respectivamente, e resultados muito diferentes foram observados dependendo do tipo de sistema utilizado. Os dados referentes à reconstituição da enzima e tamanho dos sistemas obtidos estão resumidos na Tabela 6. Como pode ser observado, para os lipossomos de DPPC:DPPS (9:1), DPPC:DPPS (8:2) e DPPC:DODAB (8:2), foram obtidas reconstituições máximas da atividade PNFFase da enzima após diferentes tempos de incubação (4 horas, 5 horas e 40 minutos, respectivamente), quando lipossomos e proteína $(23 \mu \mathrm{g} / \mathrm{mL})$ foram incubados na proporção de 1:1 (v/v), a $25^{\circ} \mathrm{C}$. Resultados semelhantes de incorporação foram obtidos por Camolezi e colaboradores (2002) na reconstituição de fosfatase alcalina de placas ósseas em lipossomos constituídos de DPPC, e por Angrand e colaboradores (1997), que empregaram um método de reconstituição de fosfatase alcalina de intestino bovino mediado por detergente. Comparativamente aos lipossomos constituídos apenas de DPPC, a proporção de atividade PNFFase reconstituída nos proteolipossomos contendo DPPS em sua composição é muito semelhante, mas a velocidade de incorporação é bem menor, necessitando de um tempo bem maior de incubação para se alcançar as mesmas porcentagens de incorporação, enquanto que, para os lipossomos de DPPC:DODAB (8:2), a curva de incorporação da enzima é bem semelhante àquela do DPPC, necessitando de apenas 40 minutos de incubação para se obter $90 \%$ de incorporação da enzima. Curiosamente, para os lipossomos de DPPC:DODAB (9:1), apenas cerca de 50\% da atividade PNFFase da enzima foi 


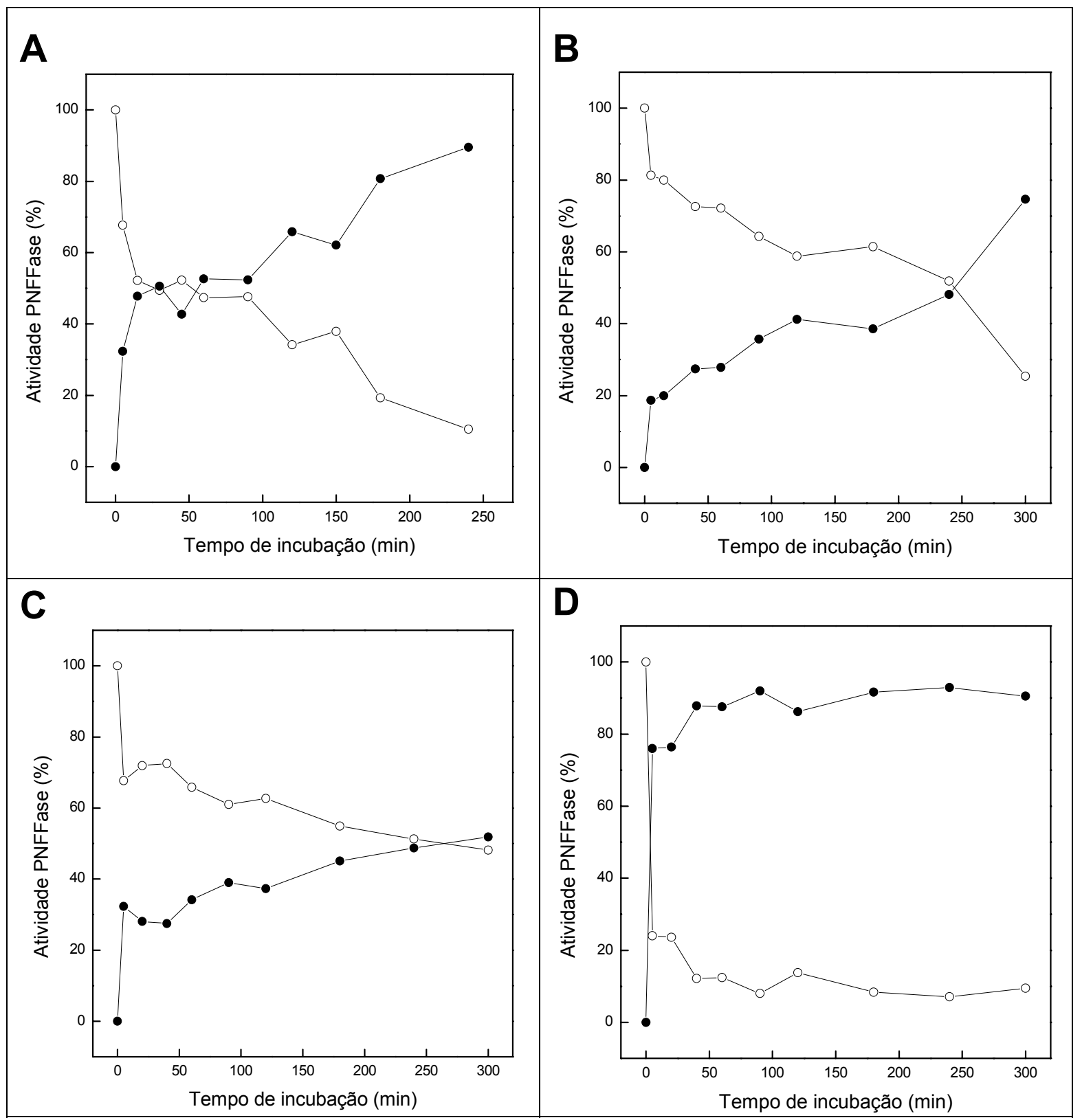

Figura 15. Incorporação da fosfatase alcalina em lipossomos mistos constituídos de (A) DPPC:DPPS (9:1), (B) DPPC:DPPS (8:2), (C) DPPC:DODAB (9:1) e (D) DPPC:DODAB (8:2), após a incubação do extrato bruto solubilizado com a resina Calbiosorb na proporção de $200 \mathrm{mg} / \mathrm{mL}$, por 2 horas, a $4^{\circ} \mathrm{C}$. Lipossomos e enzima (23 $\mu \mathrm{g} / \mathrm{mL}$ ) foram incubados em tampão Tri-HCl $50 \mathrm{mM}, \mathrm{pH} 7,5$, contendo $\mathrm{MgCl}_{2} 2$ $\mathrm{mM}$, a $25^{\circ} \mathrm{C}$ e alíquotas de $100 \mu \mathrm{L}$ foram retiradas e centrifugadas. A diminuição da atividade PNFFase no sobrenadante ou o aumento da mesma no pellet mostram que ocorreu a incorporação. (๑) Atividade PNFFase no pellet e $(O)$ atividade PNFFase no sobrenadante. 
incorporada aos lipossomos mesmo após 5 horas de incubação nas mesmas condições descritas acima, ou seja, quando este resultado é comparado com o obtido para lipossomos contendo apenas DPPC, não só a velocidade de incorporação, mas também a quantidade de fosfatase alcalina reconstituída, são bem menores. Portanto, a composição do microambiente lipídico parece modular a interação da fosfatase alcalina com os sistemas vesiculares. No caso dos lipossomos com carga positiva, ambas as velocidade e quantidade de incorporação foram marcadamente diferentes entre as duas proporções utilizadas, sendo que uma maior proporção de DODAB nos lipossomos de DPPC favoreceu a inserção da fosfatase alcalina nos sistemas após um curto período de incubação (40 minutos). Para os lipossomos contendo carga negativa em sua superfície, as diferentes proporções de DPPS utilizadas não exerceram grande influência tanto na velocidade de inserção quanto na quantidade de enzima incorporada. Todavia, para todos os sistemas, o processo de incorporação é tempo dependente, apresentando uma etapa inicial rápida de inserção da enzima, seguida por uma fase onde a incorporação torna-se mais lenta.

Os tamanhos médios dos diferentes sistemas vesiculares com a fosfatase alcalina reconstituída foram avaliados empregando-se a técnica de espalhamento de luz dinâmico, sempre no dia da preparação dos proteolipossomos. Os resultados obtidos revelaram vesículas com diâmetro médio de 200 e $270 \mathrm{~nm}$ para os proteolipossomos constituídos de DPPC:DPPS (9:1) e DPPC:DPPS (8:2), respectivamente (Tabela 6). O diâmetro maior obtido para os sistemas reconstituídos pode ser justificado pela fusão de lipossomos devido à presença da enzima na membrana da vesícula. Fleury e colaboradores (1995) ralataram que lipossomos dobravam de diâmetro, aproximadamente, quando formados na presença de interleucina. Além disso, o tamanho do sistema reconstituído depende da técnica utilizada na obtenção dos lipossomos (Arien e Dupuy, 1997). Já para os proteolipossomos constituídos de DPPC:DODAB (9:1) e DPPC:DODAB (8:2), os resultados do espalhamento revelaram sistemas com tamanhos maiores que 5.000 $\mathrm{nm}$ (limite de deteção do equipamento). Os dados referentes à reconstituição da enzima e tamanhos dos sistemas obtidos estão resumidos na Tabela 6.

Os diferentes sistemas de proteolipossomos obtidos foram tratados com hexano para a remoção do excesso de lipídios e submetidos à eletroforese em gel de poliacrilamida ( $7 \%$ ) em condições desnaturantes, revelando a presença de várias 
proteínas (Figura 16). Este experimento reforça a importância do microambiente lipídico na modulação da interação de proteínas com a membrana, pois a presença de carga na superfície dos lipossomos favoreceu a incorporação não somente da fosfatase alcalina, mas também de várias outras proteínas presentes no extrato bruto solubilizado, ao contrário dos resultados obtidos para os proteolipossomos constituídos apenas de DPPC, que quando submetidos à eletroforese nas mesmas condições, revelaram somente uma banda protéica, correspondente à fosfatase alcalina, sendo, portanto, constituídos de uma única enzima, apresentando alta eficiência de incorporação da proteína em um processo praticamente muito seletivo, pois as outras proteínas não interagiram favoravelmente com estes sistemas vesiculares que não continham carga em sua superfície.

Tabela 6. Parâmetros obtidos para a reconstituição da fosfatase alcalina em lipossomos de composições lipídicas variáveis.

\begin{tabular}{cccccc}
\hline $\begin{array}{c}\text { Composição } \\
\text { (mol:mol) }\end{array}$ & $\begin{array}{c}\text { Tempo de } \\
\text { incubação } \\
(\mathbf{m i n})\end{array}$ & $\begin{array}{c}\% \\
\text { incorporação }\end{array}$ & $\begin{array}{c}\mathbf{t}_{1 / 2} \\
(\mathbf{m i n})\end{array}$ & $\begin{array}{c}\text { Tamanho dos } \\
\text { lipossomos } \\
(\mathbf{n m})\end{array}$ & $\begin{array}{c}\text { Tamanho dos } \\
\text { proteolipossomos } \\
(\mathbf{n m})\end{array}$ \\
\hline DPPC & 40 & 90 & 10 & $100 \pm 25$ & $200 \pm 17$ \\
DPPC:DPPS (9:1) & 240 & 90 & 15 & $85 \pm 19$ & $200 \pm 11$ \\
DPPC:DPPS (8:2) & 300 & 75 & 240 & $100 \pm 17$ & $270 \pm 22$ \\
DPPC:DODAB (9:1) & 300 & 50 & 240 & $140 \pm 23$ & - \\
DPPC:DODAB (8:2) & 40 & 90 & 3,5 & $170 \pm 28$ & - \\
\hline
\end{tabular}

Uma amostra dos proteolipossomos também foi aplicada no gel, porém sem tratamento com mercapto etanol e também sem aquecimento, e após a corrida, revelada para atividade de fosfomonohidrolase. Nestas condições, apenas uma banda com massa molecular de aproximadamente $120 \mathrm{kDa}$ foi observada (resultados não mostrados). Este resultado sugere fortemente que os diferentes sistemas de proteolipossomos apresentam somente uma proteína com atividade de fosfomonohidrolase na condição experimental efetuada, com massa molecular ao redor de $120 \mathrm{kDa}$.

Uma vez padronizado o protocolo para a reconstituição da fosfatase alcalina em lipossomos mistos de diferentes composições lipídicas, apresentando elevado rendimento de incorporação da enzima às vesículas e relativa estabilidade dos 


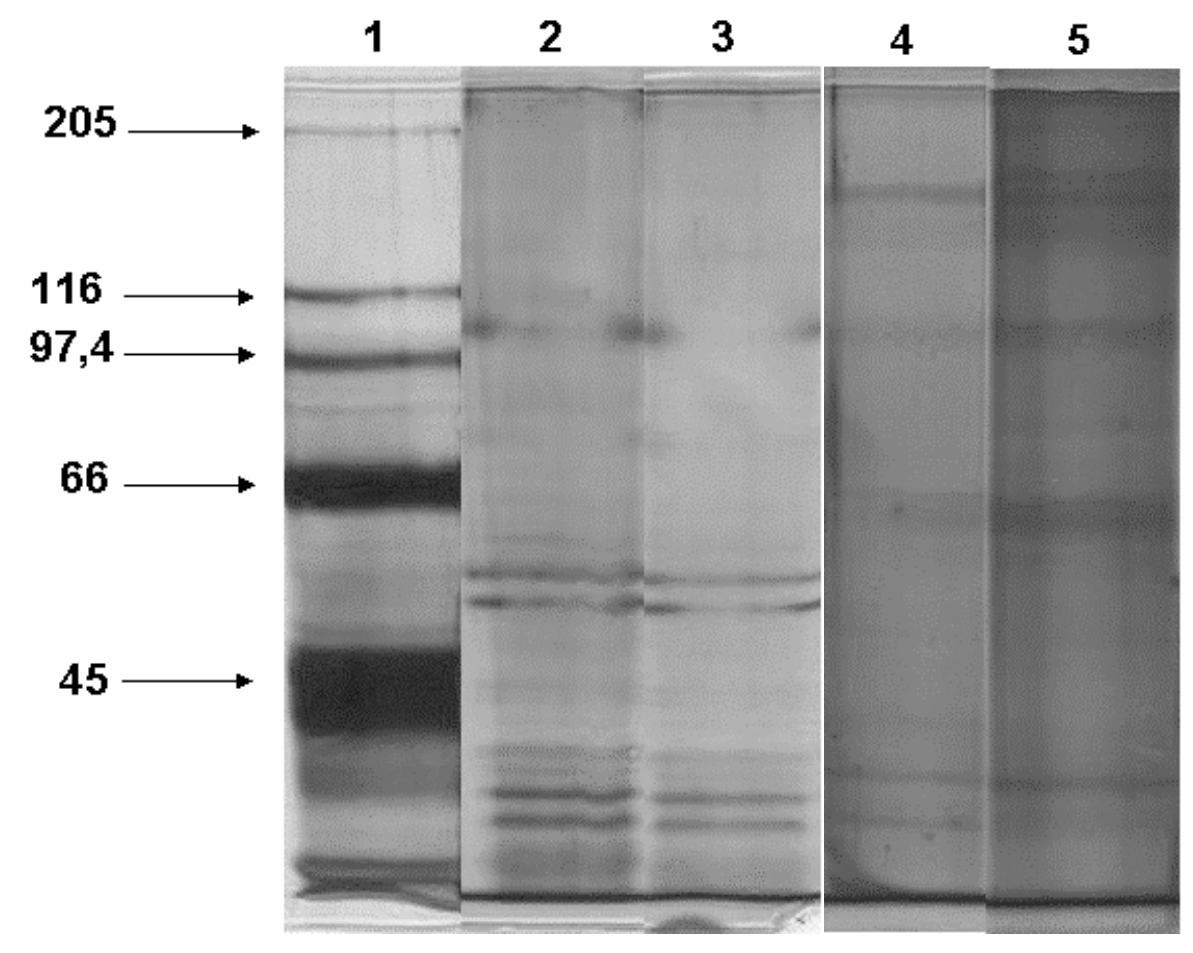

Figura 16. Eletroforese de proteolipossomos em condições desnaturantes, realizada conforme descrito no item 3.21 Material e Métodos, em um gel de poliacrilamida 7\%. As amostras foram previamente tratadas com n-hexano antes do procedimento normal para eletroforese e o gel foi revelado utilizando-se nitrato de prata. Gel 1: padrões de massa molecular; Gel 2: amostra de proteolipossomos constituídos de DPPC:DPPS (8:2); Gel 3: amostra de proteolipossomos constituídos de DPPC:DPPS (9:1); Gel 4: amostra de proteolipossomos constituídos de DPPC:DODAB (8:2); Gel 5: amostra de proteolipossomos constituídos de DPPC:DODAB (9:1). 
sistemas, foram realizados alguns experimentos com o objetivo de se caracterizar estes sistemas através de estudos de cinética de hidrólise do ATP, PP $P_{i}$ e PNFF, no intuito de se conhecer os parâmetros cinéticos (como padrões para comparação com outros sistemas e outras formas da enzima), e os resultados estão resumidos na Tabela 3, junto com os dados obtidos para a enzima associada à membrana e reconstituída em lipossomos de DPPC.

Recentes estudos têm demonstrado a importância da hidrólise de ATP e PP por fosfatases alcalinas de diferentes tecidos ósseos e cartilaginosos, e acredita-se que estas duas atividades enzimáticas estejam envolvidas na remoção de inibidores de formações minerais, fornecendo o fosfato para o mineral nascente (Cyboron et al., 1982; Hsu et al., 1985; Meyer e Reddi, 1985; Register et al., 1986; Leone et al., 1997a). Além disso, a hidrólise de ATP poderia ainda sustentar o transporte de cálcio dependente de energia para o interior das vesículas da matriz (Ali e Evans, 1973; Messer et al., 1975).

Assim, inicialmente foi verificado o efeito do microambiente do fosfolipídio no $\mathrm{pH}$ ótimo de hidrólise dos diferentes substratos pela enzima reconstituída nos lipossomos de DPPC (Figura 17). O pH ótimo de hidrólise do PNFF pela fosfatase alcalina reconstituída nos lipossomos foi 10, mantendo-se portanto o mesmo que o obtido para a enzima ligada à membrana (Simão et al., 2007a), mas ligeiramente superior ao encontrado para a fosfatase alcalina associada à membrana obtida de cartilagem induzida por matriz óssea de rato (Curti et al., 1986). Já para o PP, foi determinado um pH ótimo de hidrólise de 9, ligeiramente maior que o obtido para a enzima associada à membrana e purificada de placas ósseas de rato (Rezende et al., 1998). $\mathrm{O} \mathrm{pH}$ ótimo aparente para a hidrólise do ATP pela fosfatase alcalina reconstituída foi 9,5 , semelhante ao obtido para a enzima de placas ósseas de rato solubilizada com polidocanol (Demenis e Leone, 2000).

Após a determinação dos valores de $\mathrm{pH}$ ótimo de hidrólise dos diferentes substratos pela enzima reconstituída em lipossomos, foram iniciados os estudos para a determinação dos parâmetros cinéticos de hidrólise para os diversos substratos estudados, e os resultados estão resumidos na Tabela 3.

O efeito do aumento da concentração de PNFF na atividade PNFFase da enzima reconstituída nos lipossomos de DPPC, DPPC:DPPS (8:2) e DPPC:DODAB (9:1) é mostrado na Figura 18. A hidrólise do PNFF em pH 10 revelou uma única classe de sítios de hidrólise tanto para estes quanto para os demais sistemas 


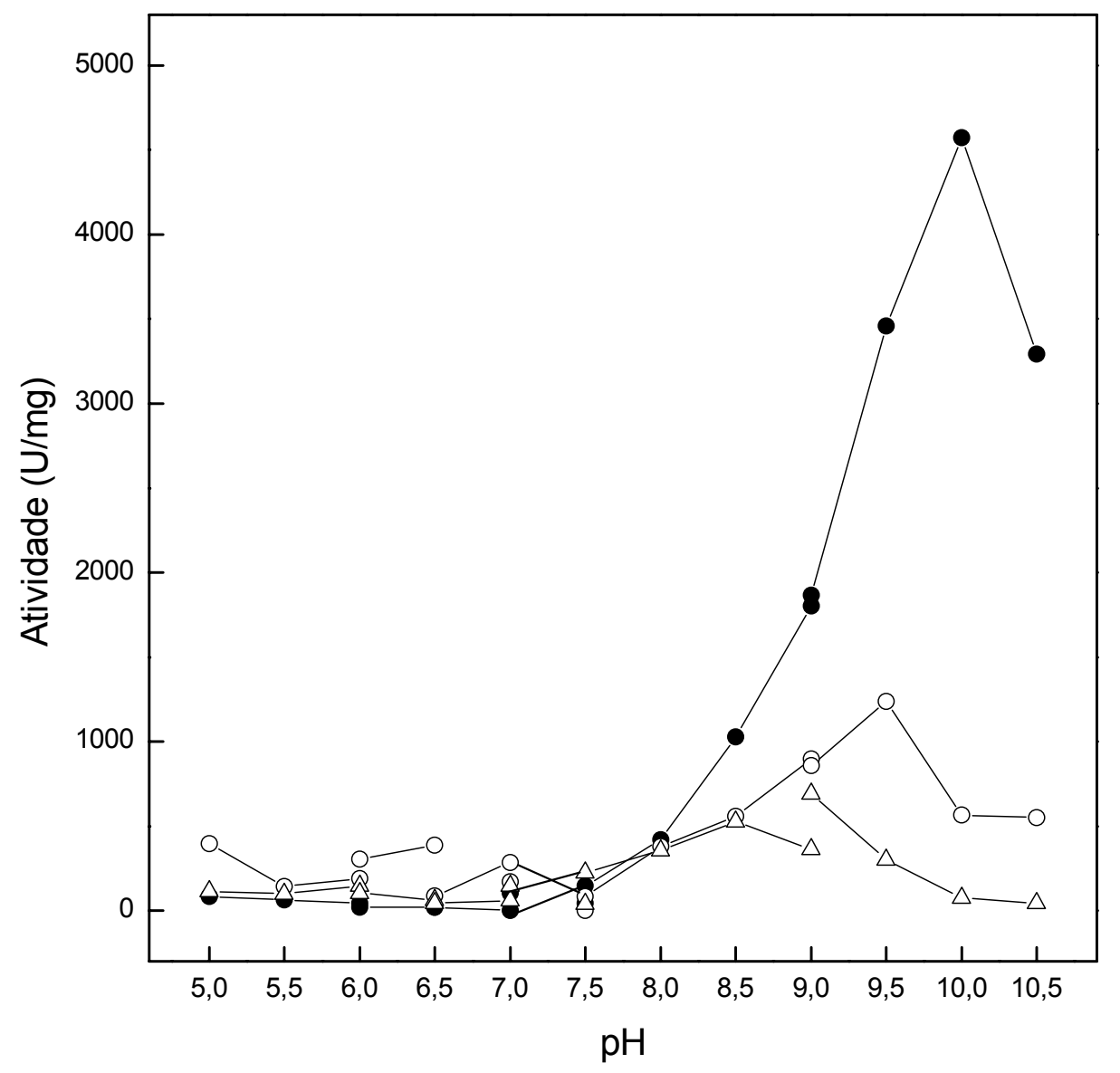

Figura 17. Determinação do $\mathrm{pH}$ ótimo de hidrólise do (๑) PNFF, (O) ATP e $(\Delta) \mathrm{PP}_{\mathrm{i}}$ pela fosfatase alcalina reconstituída em lipossomos de DPPC, na faixa de $\mathrm{pH}$ entre 5,0 e 10,5, utilizando-se os seguintes tampões: mes ( $\mathrm{pH} \mathrm{5,0-6,0),} \mathrm{bis-tris} \mathrm{(} \mathrm{pH} \mathrm{6,0-}$ 6,5), imidazol ( $\mathrm{pH} 6,5-7,5)$, Tris- $\mathrm{HCl}(\mathrm{pH} \mathrm{7,0-9,0)} \mathrm{e} \mathrm{AMPOL} \mathrm{(} \mathrm{pH} \mathrm{9,0-10,5),} \mathrm{como}$ descrito no item 3.20 de Material e Métodos. As atividades foram determinadas em $50 \mathrm{mM}$ do tampão apropriado, contendo $\mathrm{MgCl}_{2} 2 \mathrm{mM}$ e substrato. 


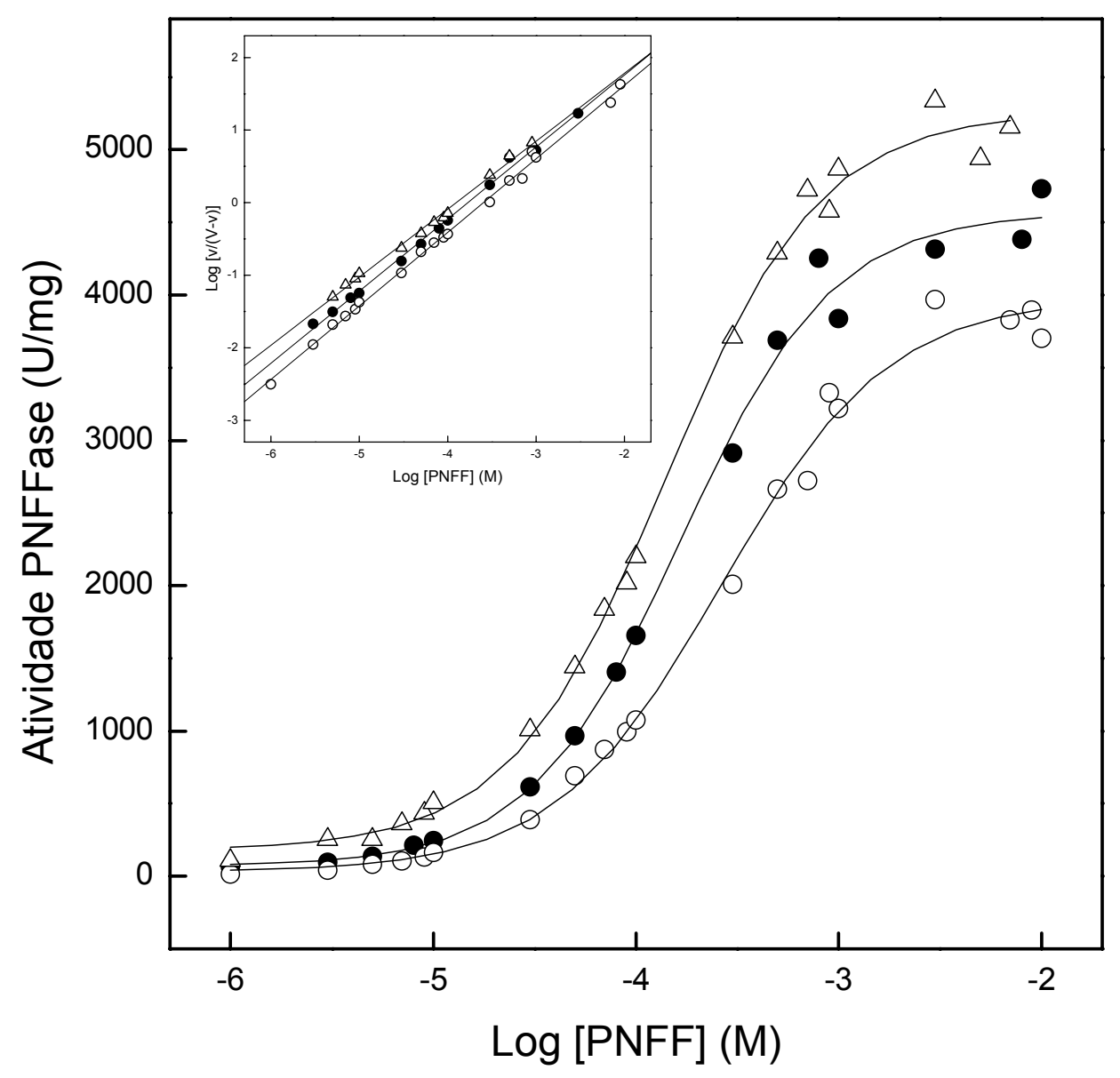

Figura 18. Efeito da concentração de PNFF na atividade enzimática da fosfatase alcalina reconstituída em lipossomos de (๑) DPPC, (O) DPPC:DPPS (8:2) e $(\Delta)$ DPPC:DODAB (9:1). A reação foi efetuada em tampão AMPOL $50 \mathrm{mM}, \mathrm{pH} 10$, contendo PNFF e $\mathrm{MgCl}_{2} 2 \mathrm{mM}$. A atividade PNFFase foi determinada conforme descrito no item 3.5 de Material e Métodos, variando-se a concentração de PNFF no meio e a reação foi iniciada pela adição dos proteolipossomos ao meio reacional. Inserção: representação de Hill para a interação do substrato com a enzima. 
estudados, não apresentando efeitos cooperativos, e com parâmetros cinéticos muito similares aos obtidos para a enzima associada à membrana (Simão et al., 2007a). Os valores obtidos para $\mathrm{K}_{0,5}$ não diferiram significativamente entre si e foram muito semelhantes aos obtidos para fosfatases alcalinas de outras fontes (Ciancaglini et al, 2006). Além disso, não foi observada nenhuma inibição pelo substrato, mesmo em uma concentração de $10 \mathrm{mM}$, e os valores obtidos para a eficiência enzimática $\left(\mathrm{k}_{\mathrm{cat}} / \mathrm{K}_{0,5}\right)$ permaneceram comparáveis entre os diferentes sistemas, semelhantes inclusive ao valor encontrado para a fração de membrana. Assim, a reconstituição da fosfatase alcalina em lipossomos de diferentes cargas, em diferentes proporções, parece não afetar significativamente o comportamento cinético da enzima em relação ao PNFF.

A hidrólise de ATP pela enzima reconstituída em lipossomos de DPPC, DPPC:DPPS (8:2) e DPPC:DODAB (9:1) é mostrada na Figura 19. Pode ser observado que o ATP exibe uma única curva de saturação para todos os sistemas estudados, com um valor de $\mathrm{K}_{0,5}$ bem diferente para o sistema constituído por DPPC:DODAB (9:1), enquanto os demais sistemas apresentaram $\mathrm{K}_{0,5}$ muito similares entre si e semelhantes aos obtidos tanto para a enzima associada à membrana de placas ósseas de ratos (Pizauro et al., 1987) quanto para a enzima presente na fração de membrana de osteoblastos (Simão et al., 2007a). Assim, uma pequena proporção de carga positiva inserida nos lipossomos de DPPC parece aumentar a afinidade da enzima pelo ATP, enquanto uma maior proporção de carga positiva parece reduzir esta afinidade. Para concentrações de ATP acima de $8 \mathrm{mM}$ para o proteolipossomo de DPPC, acima de $5 \mathrm{mM}$ para os sitemas contendo DODAB e acima de $7 \mathrm{mM}$ para as vesículas constituídas de DPPS, foi observada inibição da atividade ATPase da enzima reconstituída nestes sistemas. Com exceção da fração de membrana e dos sistemas contendo DODAB em sua composição, foi observada cooperatividade positiva para todos os demais sistemas estudados, sendo esta cooperatividade mais acentuada para os sistemas constituídos de DPPC:DPPS (9:1). Portanto, a inserção de carga positiva aos lipossomos de DPPC, independentemente da proporção utilizada, parece induzir o desaparecimento da cooperatividade observada nos demais sistemas. Com relação à eficiência enzimática, os valores obtidos para os sistemas constituídos somente de DPPC e de DPPC:DODAB, em ambas as proporções, aumentaram cerca de 10 vezes em relação à fração de membrana e aos sistemas contendo DPPS. 


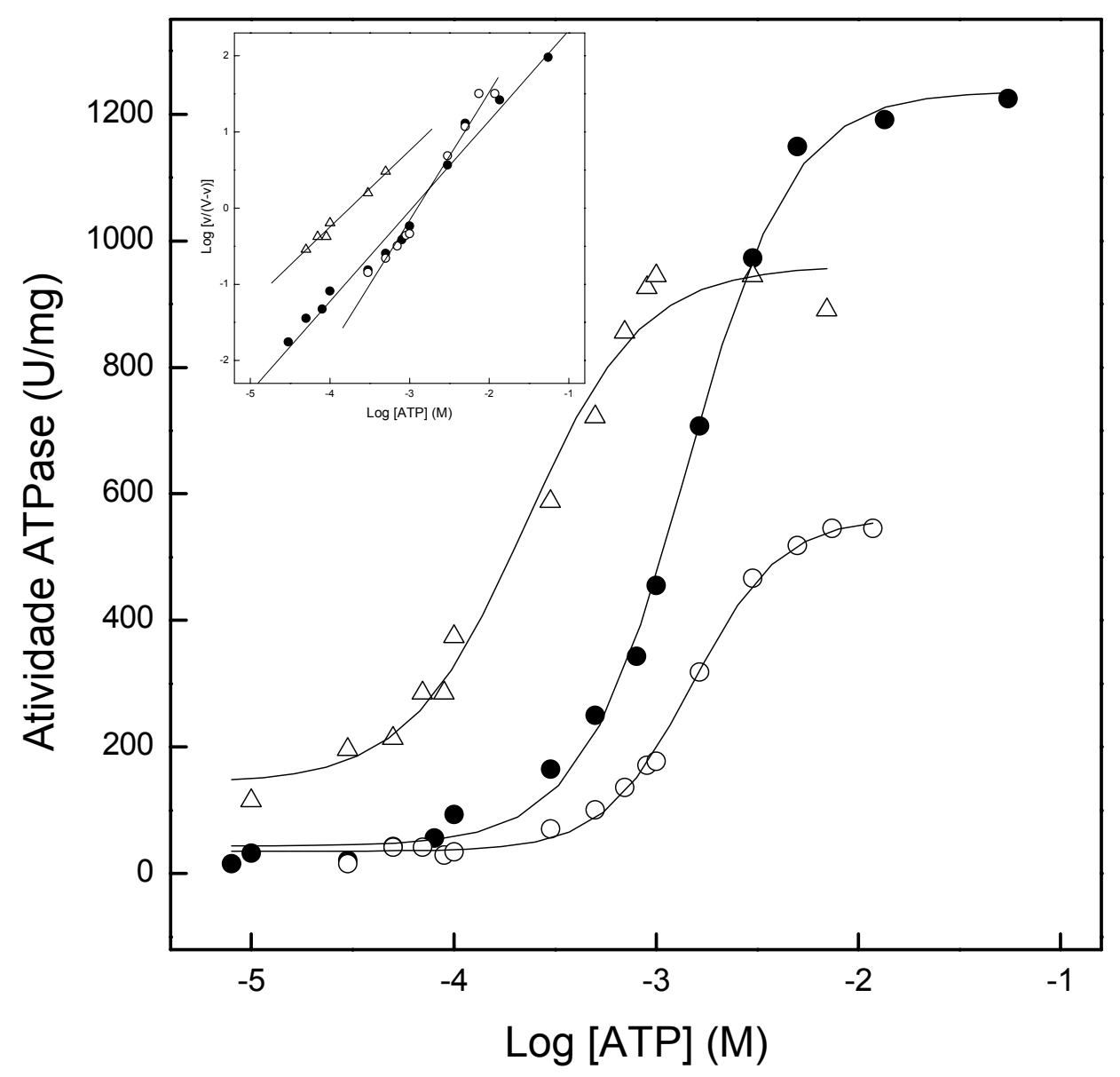

Figura 19. Efeito da concentração de ATP na atividade enzimática da fosfatase alcalina reconstituída em lipossomos de (๑) DPPC, (O) DPPC:DPPS (8:2) e $(\Delta)$ DPPC:DODAB (9:1). A reação foi efetuada em tampão AMPOL $50 \mathrm{mM}, \mathrm{pH}$ 9,5, contendo ATP e $\mathrm{MgCl}_{2} 2 \mathrm{mM}$. A atividade ATPase foi determinada conforme descrito no item 3.6 de Material e Métodos, variando-se a concentração de ATP no meio e a reação foi iniciada pela adição dos proteolipossomos ao meio reacional. Inserção: representação de Hill para a interação do substrato com a enzima. 
A hidrólise de $\mathrm{PP}_{\mathrm{i}}$ pela enzima reconstituída em lipossomos de DPPC, DPPC:DPPS (8:2) e DPPC:DODAB (8:2) é mostrada na Figura 20, e apresentou efeitos cooperativos positivos para todos os sistemas estudados, sendo estes efeitos mais pronunciados nos sistemas reconstituídos do que na enzima associada à membrana. Uma única curva de saturação foi observada para todos os sistemas, com valores de $\mathrm{K}_{0,5}$ muito semelhantes entre si e similares aos obtidos para a enzima associada à membrana (Simão et al., 2007a), logo a afinidade da enzima pelo substrato não foi grandemente afetada pela sua reconstituição nos diferentes sistemas. Para concentrações de $\mathrm{PP}_{\mathrm{i}}$ acima de $5 \mathrm{mM}$ para o proteolipossomo de DPPC e acima de $4 \mathrm{mM}$ para as vesículas constituídas de DODAB e DPPS, foi observada inibição da atividade PPase da enzima reconstituída nestes sistemas. Resultados contraditórios, empregando fosfatase alcalina obtida de placas ósseas de ratos, têm sido encontrados na literatura (Leone et al., 1998; Rezende et al., 1998). Os valores obtidos para a eficiência catalítica foram cerca de 10 vezes maiores para os sistemas contendo DODAB quando comparados aos demais sistemas e à enzima associada à membrana.

É importante ressaltar também que, para todos os sistemas e substratos estudados, houve uma ativação da atividade específica da enzima incorporada quando comparada com a enzima associada à membrana, ou seja, a enzima reconstituída não perde a habilidade de hidrolisar nenhum dos substratos estudados, como demonstrado por Camolezi e colaboradores (2002).

\subsection{Reconstituição da fosfatase alcalina em células ghost resseladas e caracterização cinética dos sistemas fosfatase alcalina-células ghost}

Vários estudos que utilizam lipossomos também podem ser realizados empregando-se células ghost resseladas, com a vantagem de estas apresentarem algumas proteínas do eritrócito associadas à bicamada lipídica, mimetizando ainda mais um sistema de membrana natural que, se empregado in vivo, pode resultar em uma menor resposta imune.

O eritrócito é um material de partida muito conveniente para a preparação de células ghost resseladas, como modelos de membrana, porque não possui organelas com membranas, sendo a membrana plasmática a única membrana presente nestas células. Assim, foram realizados os estudos de reconstituição da fosfatase alcalina empregando-se células ghost resseladas. 


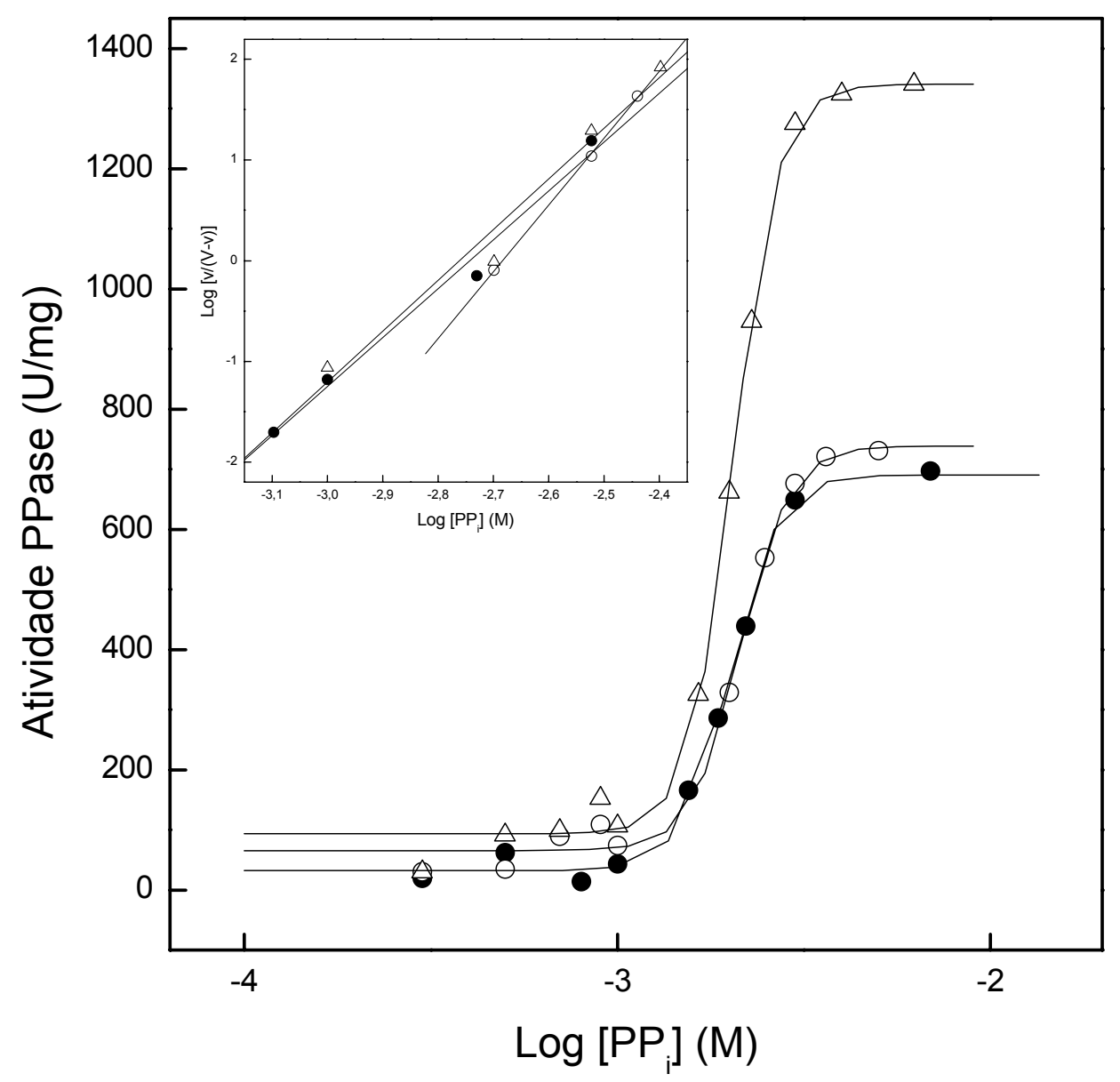

Figura 20. Efeito da concentração de $\mathrm{PP}_{\mathrm{i}}$ na atividade enzimática da fosfatase alcalina reconstituída em lipossomos de (๑) DPPC, (O) DPPC:DPPS (8:2) e $(\Delta)$ DPPC:DODAB (8:2). A reação foi efetuada em tampão AMPOL $50 \mathrm{mM}, \mathrm{pH}$ 9, contendo $\mathrm{PP}_{\mathrm{i}}$ e $\mathrm{MgCl}_{2} 2 \mathrm{mM}$. A atividade PPase foi determinada conforme descrito no item 3.7 de Material e Métodos, variando-se a concentração de $\mathrm{PP}_{\mathrm{i}}$ no meio e a reação foi iniciada pela adição dos proteolipossomos ao meio reacional. Inserção: representação de Hill para a interação do substrato com a enzima. 
As células ghost resseladas foram preparadas como descrito em Material e Métodos, onde as mudanças nos tampões originais do método descrito por Doberstein e colaboradores (1995), a base de fosfato de sódio, foram feitas a partir do cálculo das forças iônicas dos tampões originais, para que o íon fosfato pudesse ser substituído por Tris- $\mathrm{HCl}$, contendo $\mathrm{NaCl}$ em uma concentração apropriada, pois o fosfato é um inibidor da fosfatase alcalina e seria impossível monitorar a atividade da enzima na presença deste íon.

A curva de incorporação da fosfatase alcalina, solubilizada com polidocanol e livre de detergente, às células ghost resseladas pode ser observada na Figura 21. A incorporação foi obtida pela mistura de volumes iguais de enzima $(23 \mu \mathrm{g} / \mathrm{mL})$ e células ghost resseladas $(0,22 \mathrm{mg} / \mathrm{mL})$. Como pode ser observado, a incorporação da atividade PNFFase da fosfatase alcalina foi de cerca de $40 \%$ após 2 horas de incubação, a $25^{\circ} \mathrm{C}$. Resultados contraditórios foram relatados por lerardi e colaboradores (2002), que obtiveram cerca de 50\% de incorporação de fosfatase alcalina de placas ósseas em células ghost resseladas, mas após um período de incubação de 48 horas. As diferenças encontradas para a incorporação da enzima utilizando-se células ghost podem ser devido às condições de incubação, já que lerardi e colaboradores (2002) incubaram a enzima com células ghost a $4^{\circ} \mathrm{C}$, enquanto em nosso trabalho a incubação foi realizada a $25^{\circ} \mathrm{C}$. Sabendo-se que a temperatura exerce grande influência sobre a fluidez de membranas, as diferenças encontradas podem ser justificadas com base nas diferentes condições experimentais utilizadas, já que uma menor fluidez da membrana dificulta a inserção da âncora GPI da enzima, responsável pela incorporação, à bicamada lipídica.

Além disso, a metodologia utilizada por lerardi e colaboradores (2002) resulta na formação de vesículas inside-out, devido à presença de cálcio no tampão de resselagem, como demonstrado por Steck e colaboradores (1970), enquanto nossa metodologia, baseada naquela descrita por Doberstein e colaboradores (1995), na ausência de cálcio, favorece a formação de vesículas right-side-out, facilitando a reconstituição da enzima. Assim, as grandes diferenças encontradas nos tempos de incubação para a reconstituição da enzima, entre a metodologia de lerardi e colaboradores (2002) e a descrita no presente trabalho, sugerem fortemente a formação de vesículas right-side-out.

O tempo de incorporação da fosfatase alcalina em células ghost resseladas foi maior do que o obtido para a reconstituição da enzima em alguns lipossomos, 


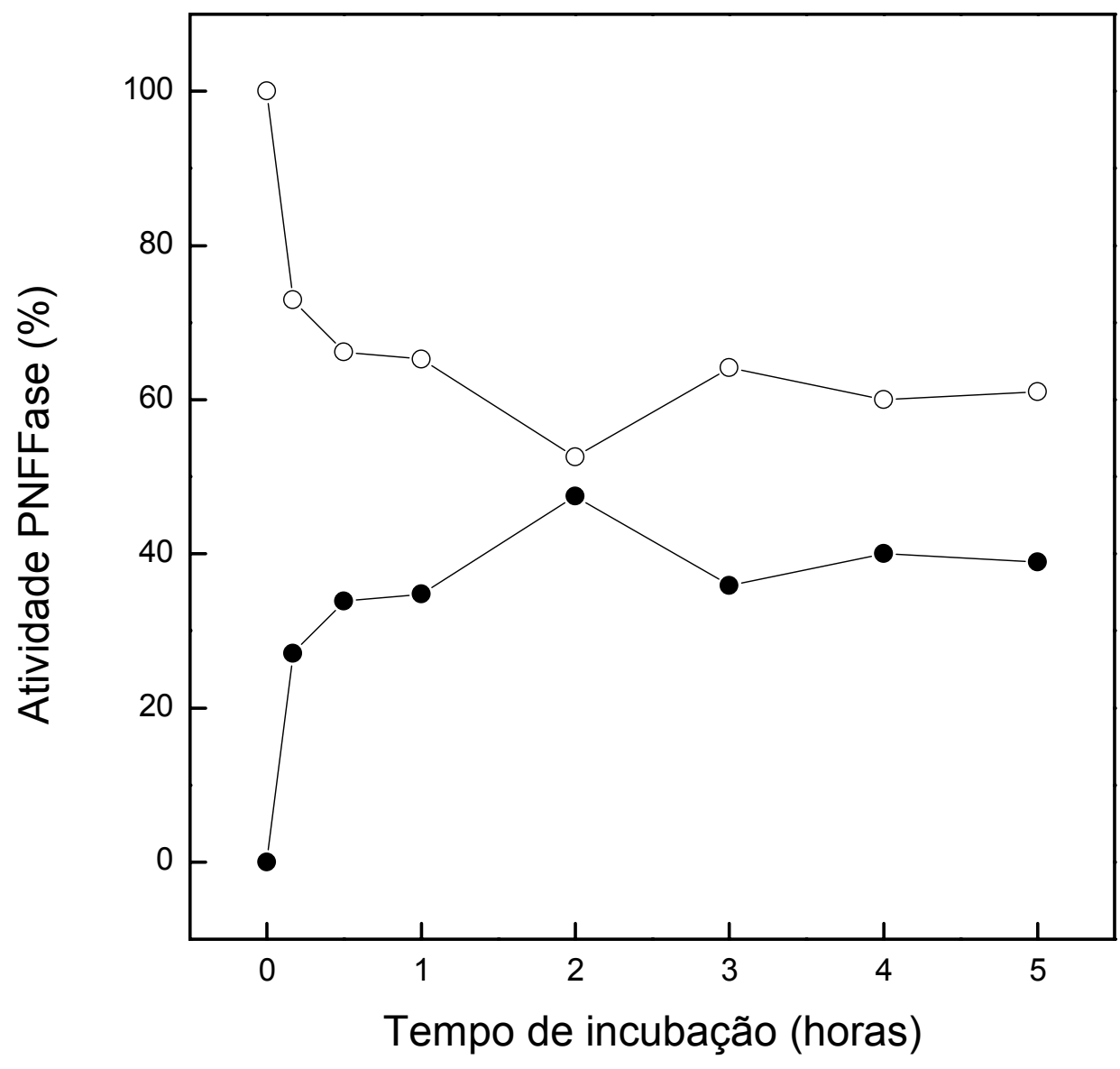

Figura 21. Incorporação da fosfatase alcalina em células ghost resseladas, após a incubação do extrato bruto solubilizado com a resina Calbiosorb na proporção de $200 \mathrm{mg} / \mathrm{mL}$, por 2 horas, a $4^{\circ} \mathrm{C}$. Células ghost resseladas $(0,22 \mathrm{mg} / \mathrm{mL})$ e enzima $(23$ $\mu \mathrm{g} / \mathrm{mL}$ ) foram incubadas por 5 horas, a $25^{\circ} \mathrm{C}$, e alíquotas foram retiradas e centrifugadas. A diminuição da atividade PNFFase no sobrenadante ou o aumento da mesma no pellet mostram que ocorreu a incorporação. (•) Atividade PNFFase no pellet e $(\mathrm{O})$ atividade PNFFase no sobrenadante. 
além da proporção de proteína incorporada também ser menor. Este fato provavelmente ocorre devido à presença de proteínas na membrana das células ghost resseladas, que podem dificultar a aproximação da âncora GPI da fosfatase alcalina, responsável pela incorporação (Kihn et al., 1990). Outro fator que pode justificar este tempo maior para a incorporação é que estas proteínas podem contribuir para um maior empacotamento dos fosfolipídios presentes na membrana do eritrócito, dificultando assim a interação da âncora GPI da enzima com a membrana (Gennis, 1989; Kihn et al., 1990).

Estudos de microscopia eletrônica demonstraram que os sistemas de células ghost resseladas foram obtidos com êxito, revelando a presença de vesículas fechadas (Figura 22). O tamanho destas vesículas pode ser muito variável, dependendo do procedimento utilizado para a obtenção das vesículas e da técnica empregada para a obtenção das imagens por microscopia (Steck et al., 1970; Takeuchi et al., 1998), mas em nossas preparações foi obtido um diâmetro médio, relativamente regular, da ordem de $400 \mathrm{~nm}$.

Uma amostra de células ghost com fosfatase alcalina reconstituída foi incubada com fosfolipase $C$ de Bacillus thuringiensis (PIPLC) na proporção de $0,2 U$ de PIPLC/mL de suspensão, por 2 horas, a $37^{\circ} \mathrm{C}$. O tratamento do sistema com PIPLC solubilizou quase toda a enzima (cerca de 90\%), sugerindo que a interação da fosfatase alcalina com a membrana das células ghost ocorre via âncora GPI, como demonstrado anteriormente por lerardi e colaboradores (2002).

Após a padronização da reconstituição da fosfatase alcalina em células ghost resseladas, foram realizados os experimentos para a determinação dos parâmetros cinéticos de hidrólise de diferentes substratos pela enzima reconstituída, e os resultados estão resumidos na Tabela 7 .

Tabela 7. Parâmetros cinéticos obtidos para a hidrólise de PNFF, ATP e PPi pela fosfatase alcalina reconstituída em células ghost resseladas.

\begin{tabular}{ccccc}
\hline Substratos & $\mathbf{V}_{\mathbf{m}} \mathbf{( U / m g )}$ & $\mathbf{K}_{\mathbf{0 , 5}}(\mathbf{m M})$ & $\mathbf{n}$ & $\mathbf{k}_{\text {cat }} / \mathbf{K}_{\mathbf{0}, \mathbf{5}}\left(\mathbf{M}^{-1} \cdot \mathbf{s}^{-1}\right)$ \\
\hline PNFF & 478,6 & 0,22 & 0,9 & $4,4 \times 10^{3}$ \\
ATP & 71,8 & 1,2 & 1,2 & $1,2 \times 10^{2}$ \\
PP $_{\mathbf{i}}$ & 77,4 & 1,5 & 5,0 & $1,0 \times 10^{2}$ \\
\hline
\end{tabular}




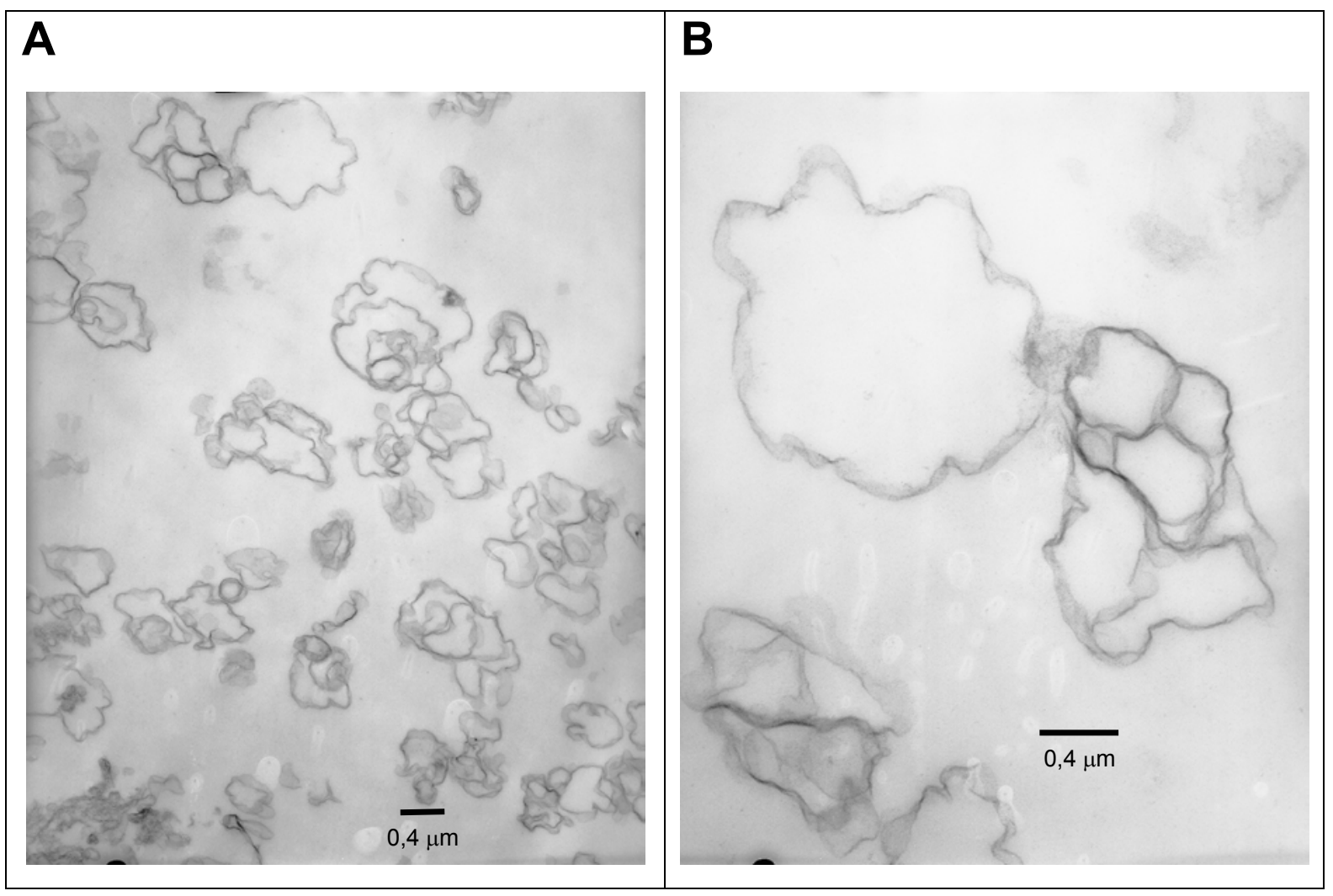

Figura 22. Microscopia eletrônica de células ghost resseladas com ampliação de (A) 13.000x e (B) 25.000x. As amostras foram preparadas e as imagens obtidas como descrito no item 3.24 de Material e Métodos. 
$\mathrm{Na}$ Figura 23 são mostrados os efeitos do aumento da concentração de PNFF, ATP e PPi sobre a atividade da enzima reconstituída em células ghost resseladas, e pode ser observado que a enzima reconstituída não perde a habilidade de hidrolisar nenhum dos substratos estudados. Uma maior velocidade de hidrólise foi observada quando PNFF foi utilizado como substrato. Para todos os substratos estudados foi observada cooperatividade, sendo esta cooperatividade mais acentuada quando $\mathrm{PP}_{\mathrm{i}}$ foi utilizado como substrato. Enquanto a eficiência enzimática $\left(\mathrm{k}_{\mathrm{cat}} / \mathrm{K}_{0,5}\right)$ manteve-se comparável para a hidrólise de ATP e PP pela enzima reconstituída, o valor de $\left(\mathrm{k}_{\mathrm{cat}} / \mathrm{K}_{0,5}\right)$ aumentou cerca de 10 vezes quando PNFF foi utilizado como substrato, sugerindo que a eficiência catalítica da enzima pode ser fortemente afetada por moléculas associadas a ela.

A hidrólise do PNFF em pH 10 revelou uma única classe de sítios de hidrólise, com valores de $\mathrm{K}_{0,5}$ e $\mathrm{n}$ muito similares aos obtidos para a enzima associada à membrana (Simão et al., 2007a) e reconstituída nos diferentes lipossomos. Além disso, não foi observada nenhuma inibição pelo substrato, mesmo em uma concentração de 100 mM, e o valor obtido para a eficiência enzimática $\left(k_{c a t} / K_{0,5}\right)$ foi cerca de 10 vezes menor do que o encontrado para a fração de membrana e para os diversos sistemas de proteolipossomos.

Para a hidrólise de ATP foi observada uma única curva de saturação, com um valor de $\mathrm{K}_{0,5}$ muito semelhante aos obtidos tanto para a enzima associada à membrana de placas ósseas de ratos (Pizauro et al., 1987), quanto para a enzima presente na fração de membrana de osteoblastos (Simão et al., 2007a) e também reconstituída em alguns lipossomos. Para concentrações de ATP acima de $5 \mathrm{mM}$, foi observada inibição da atividade ATPase da enzima reconstituída. Com relação à eficiência enzimática, o valor obtido para o sistema reconstituído manteve-se comparável ao encontrado para a fração de membrana e para alguns dos sistemas de proteolipossomos.

Para a hidrólise de $\mathrm{PP}_{\mathrm{i}}$, o valor de $\mathrm{K}_{0,5}$ foi relativamente menor do que o obtido para a enzima associada à membrana (Simão et al., 2007a), logo a enzima reconstituída em células ghost parece ter uma afinidade maior pelo substrato do que a enzima ligada à membrana. Para concentrações de $\mathrm{PP}_{\mathrm{i}}$ acima de $3 \mathrm{mM}$, foi observada inibição da atividade PPase da enzima reconstituída. Resultados contraditórios, empregando fosfatase alcalina obtida de placas ósseas de ratos, têm sido encontrados na literatura (Leone et al., 1998; Rezende et al., 1998). Os valores 


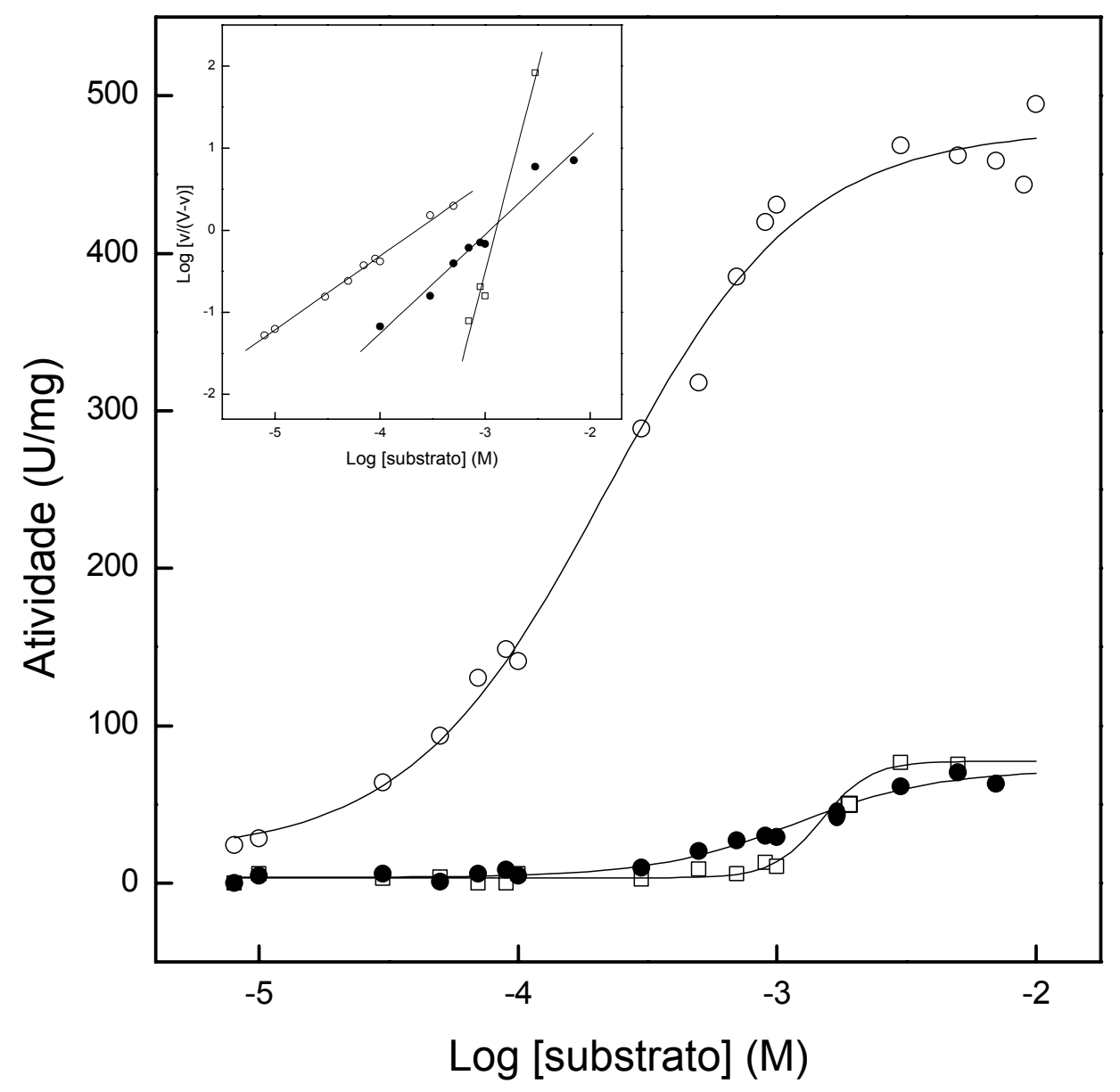

Figura 23. Efeito da concentração de (O) PNFF, (๑) ATP e $(\square) \mathrm{PP}_{\mathrm{i}}$ na atividade enzimática da fosfatase alcalina reconstituída em células ghost resseladas. As reações foram efetuadas em tampão AMPOL 50 mM, pH 10, pH 9,5 e pH 9,0 para PNFF, ATP e $\mathrm{PP}_{\mathrm{i}}$, respectivamente, contendo $\mathrm{MgCl}_{2} 2 \mathrm{mM}$ e substrato. As atividades PNFFase, ATPase e PPase foram determinadas conforme descrito nos itens 3.5, 3.6 e 3.7, respectivamente, de Material e Métodos, variando-se a concentração de substrato no meio, e as reações foram iniciadas pela adição do sistema aos meios reacionais. Inserção: representação de Hill para a interação dos substratos com a enzima. 
obtidos para a eficiência catalítica foram similares aos encontrados para a enzima associada à membrana (Simão et al., 2007a) e também reconstituída em alguns lipossomos.

Os valores de atividade obtidos para a enzima reconstituída variam muito entre os resultados encontrados na literatura. A recuperação da atividade catalítica nos proteolipossomos depende tanto da fonte e método de obtenção da proteína, bem como da metodologia empregada para sua reconstituição. Assim, os parâmetros cinéticos aqui relatados encontrados para os diferentes sistemas estudados são válidos para as condições específicas utilizadas em nosso meio reacional, pois se sabe que a atividade da enzima é dependente tanto da concentração e do tipo de substrato utilizados nos ensaios, bem como das espécies iônicas presentes no meio, podendo sofrer a modulação de sua atividade por ambos, e ainda da metodologia utilizada para a determinação da atividade enzimática dos sistemas reconstituídos (Curti et al., 1986; Say et al., 1991; Leone et al., 1992, 1998; Pizauro et al., 1987, 1993, 1995; Ciancaglini et al., 1989, 1990b, 2006; Rezende et al., 1998; Demenis e Leone, 2000; Gonçalves et al., 2002; Simão et al., 2007a,b). 


\section{Conclusão}

O método descrito para se obter uma fração de membrana rica em fosfatase alcalina, que apresenta altos níveis de atividade PNFFase, a partir de culturas de células osteoblásticas é simples, rápido e eficiente, sendo uma excelente fonte de enzima para estudos de mineralização biológica. Com esta técnica, há uma considerável redução do tempo necessário para se obter a fração de membrana, o que contribui para um menor efeito desnaturante sobre a enzima. Além disso, a metodologia padronizada resulta em uma ótima ferramenta para a eficiente reconstituição da fosfatase alcalina em sistemas vesiculares de lipossomos e células ghost resseladas, sem a necessidade de se empregar etapas prévias de purificação da enzima solubilizada com polidocanol.

As diferenças cinéticas encontradas para diferentes formas da enzima, bem como para a enzima reconstituída em células ghost resseladas e em lipossomos de composições lipídicas variáveis, demonstram que o microambiente lipídico é capaz de modular a atividade enzimática de diferentes modos e sugerem que a membrana lipídica tem uma importante função como agente de nucleação, proteção e/ou ativação durante o processo de biomineralização (Eanes e Hailer, 1985; Eanes, 1989; Skrtic e Eanes, 1992). De fato, Ciancaglini e colaboradores (2006) demonstraram recentemente que a fosfatase alcalina de placas ósseas pode ser modulada pelo substrato que está sendo hidrolisado, e apresenta constantes cinéticas distintas dependendo do microambiente onde se encontra (associada à membrana, solubilizada com detergente ou tratada com PIPLC).

Esta modulação da atividade pelo microambiente lipídico parece ser comum em enzimas que possuem âncora GPI. Lehto e Sharom (1998) demonstraram a redução da eficiência catalítica da enzima 5-nucleotidase com a inserção da mesma em lipossomos de diferentes composições lipídicas, sendo a atividade recuperada com a liberação da enzima das membranas após tratamento dos proteolipossomos com PIPLC, e relataram que o grau de redução depende da natureza da bicamada lipídica na qual a âncora GPI encontra-se inserida, sugerindo que diferentes lipídios afetam a atividade desta enzima de diferentes modos, possivelmente alterando a conformação da proteína através de mudanças estruturais transmitidas através da âncora GPI (Lehto e Sharom, 2002b). Além disso, mudanças na fluidez da membrana também podem modular as propriedades catalíticas de proteínas 
ancoradas apenas pela proximidade entre a proteína e a superfície da membrana, independentemente de mudanças conformacionais induzidas por este contato (Lehto e Sharom, 2002b).

As propriedades da membrana parecem também modular a atividade catalítica de PIPLC na clivagem de âncoras GPI, e esta modulação também é dependente das características da fosfolipase utilizada (Sharom et al., 1996), sendo a eficiência da clivagem altamente dependente da composição lipídica e propriedades da bicamada, como carga superficial e fluidez (Lehto e Sharom, 1998, 2002a).

Assim, os dados aqui apresentados reforçam a hipótese da importância do microambiente lipídico para a modulação tanto da atividade da fosfatase alcalina, quanto da interação de proteínas com a membrana.

Acreditamos que, empregando-se este protocolo de obtenção dos sistemas vesiculares de lipossomos ou células ghost com fosfatase alcalina reconstituída, é possível avaliar diferentes aspectos do envolvimento da enzima e dos lipídios durante o processo de osteogênese, pois estes sistemas podem mimetizar a função das vesículas da matriz tanto em sistemas in vitro bem como in vivo, e tais estudos poderão contribuir para um significativo avanço do conhecimento tanto da função da enzima quanto do papel dos lipídios durante o processo de mineralização biológica. 


\section{Referências bibliográficas}

Adams, C.S. and Shapiro, I.M. (2002) The fate of the terminally differentiated chondrocyte: evidence for microenvironmental regulation of chondrocyte apoptosis. Crit. Rev. Oral Biol. Med. 13: 465-73.

Addison, W.N.; Azari, F.; Sorensen, E.S.; Kaartinen, M.T. and McKee, M.D. (2007) Pyrophosphate inhibits mineralization of osteoblast cultures by binding to mineral, up-regulating osteopontin, and inhibiting alkaline phosphatase activity. J. Biol. Chem. 282: 15872-83.

Alberts, B.; Bray, D.; Lewis, J.; Raff, M.; Roberts, K. and Watson, J.D. (1994) In: "Biologia Molecular da Célula". Ed. Artes Médicas, pp. 1294.

Ali, S.Y.; Sajdera, S.W. and Anderson, H.C. (1970) Isolation and characterization of calcifying matrix vesicles from epiphyseal cartilage. Proc. Natl. Acad. Sci. USA $\underline{67}$ : 1513-20.

Ali, S.Y. (1976) Analysis of matrix vesicles and their role in the calcification of epiphyseal cartilage. Fed. Proc. $\underline{35}$ : 135-42.

Ali, S.Y. and Evans, L. (1973) The uptake of ${ }^{45}$ Ca-calcium ions by matrix vesicles isolated from calcifying cartilage. Biochem. J. 134: 647-50.

Anderson, H.C. (1973) Calcium accumulating vesicles in the intercellular matrix bone, in hard tissue growth, repair and remineralization. Ciba Fundation Symposium 11 (New Series) Elsever. New York. pp. 213-26.

Anderson, H.C. (1976) Matrix vesicle calcification. Fed. Proc. 35: 105-8.

Anderson, H.C. (1995) Molecular biology of matrix vesicles. Clin. Orthop. Rel. Research. 314: 266-80.

Anderson, H.C.; Hsu, H.H.; Morris, D.C.; Fedde, K.N. and Whyte, M.P. (1997) Matrix vesicles in osteomalacic hypophosphatasia bone contain apatite-like mineral crystals. Am. J. Pathol. 151: 1555-61.

Anderson, H.C. (2003) Matrix vesicles and calcification. Curr. Rheumatol. Rep. $\underline{5}$ : 222-6.

Anderson, H.C.; Sipe, J.B.; Hessle, L.; Dhamyamraju, R.; Atti, E.; Camacho, N.P. and Millán, J.L. (2004) Impaired calcification around matrix vesicles of growth plate and bone in alkaline phosphatase-deficient mice. Am. J. Pathol. 164: 841-7.

Anderson, H.C.; Garimella, R. and Tague, S.E. (2005) The role of matrix vesicles in growth plate development and biomineralization. Front. Biosci. 10: 822-37.

Angrand, M.; Briolay, A.; Ronzon, F. and Roux, B. (1997) Detergent-mediated reconstitution of a glycosyl-phosphatidylinositol-protein into liposomes. Eur. J. Biochem. 250: 168-76. 
Argiro, L.; Desbarats, M.; Glorieux, F.H. and Ecarot, B. (2001) Mepe, the gene encoding a tumor-secreted protein in oncogenic hypophosphatemic osteomalacia, is expressed in bone. Genomics $\underline{74}$ : $342-51$.

Arien, A.; Henry-Toulme, N. and Dupuy, B. (1994) Calcitonin-loaded liposomes: stability under acidic conditions and bile salts-induced disruption resulting in calcitonin-phospholipid complex formation. Biochim. Biophys. Acta 1193: 93-100.

Arien, A. and Dupuy, B. (1997) Encapsulation of calcitonin in liposomes depends on the vesicle preparation method. J. Microencapsul. 14: 753-60.

Arsov, Z.; Schara, M.; Zorko, M. and Strancar, J. (2004) The membrane lateral domain approach in the studies of lipid-protein interaction of GPI-anchored bovine erythrocyte acetylcholinesterase. Eur. Biophys. J. 33: 715-25.

Bangham, A.D.; Standish, M.M. and Watkins, J.C. (1965) Diffusion of univalent ions across the lamellae of swollen phospholipids. J. Mol. Biol. 13: 238-52.

Beck, G.R.; Zerler, B. and Moran, E. (2000) Phosphate is a specific signal for induction of osteopontin gene expression. Proc. Natl. Acad. Sci. USA 97: 8352-7.

Bellet-Amalric, E.; Blaudez, D.; Desbat, B.; Graner, F.; Gauthier, F. and Renault, A. (2000) Interaction of the third helix of Antennapedia homeodomain and a phospholipid monolayer, studied by ellipsometry and PM-IRRAS at the air-water interface. Biochim. Biophys. Acta 1467: 131-43.

Benatti, C.R.; Feitosa, E.; Fernandez, R.M. and Lamy-Freund, M.T. (2001) Structural and thermal characterization of dioctadecyldimethylammonium bromide dispersions by spin labels. Chem. Phys. Lipids 111: 93-104.

Benatti, C.R.; Epand, R.M. and Lamy, M.T. (2007) Low cholesterol solubility in DODAB liposomes. Chem. Phys. Lipids 145: 27-36.

Bernard, G.W. (1978) Ultrastructural localization of alkaline phosphatase in initial intramembranous osteogenesis. Clin. Orthop. Relat. Res. 135: 218-25.

Blandford, N.R.; Sauer, G.R.; Genge, B.R.; Wu, L.N. and Wuthier, R.E. (2003) Modeling of matrix vesicle biomineralization using large unilamellar vesicles. J. Inorg. Biochem. 94: 14-27.

Blum, H.; Beir, H. and Gross, H.J. (1987) Improved silver staining of plant proteins, RNA and DNA in polyacrilamide gels. Electroforesis $\underline{8}$ : 93-9.

Blumenthal, N.C. (1989) Mechanism of inhibition of calcification. Clin. Orthop. 247: 279-89.

Bollen, M.; Gijsbers, R.; Ceulemans, H.; Stalmans, W. and Stefan, C. (2000) Nucleotide pyrophosphatases/phosphodiesterases on the move. Crit. Rev. Biochem. Mol. Biol. 35: 393-432. 
Bonucci, E. (1971) The locus of initial calcification in cartilage and bone. Clin. Orthop. 78: 108-39.

Boskey, A.L. (1981) Current concepts of the physiology and biochemistry of calcification. Clin. Orthop. 157: 225-57.

Boskey, A.L. and Dick, B.L. (1991) The effect of phosphatidylserine on in vitro hydroxyapatite growth and proliferation. Calcif. Tissue Int. 49: 193-6.

Boskey, A.L.; Ullrich, W.; Spevak, L. and Gilder, H. (1996) Persistence of complexed acidic phospholipids in rapidly mineralizing tissues is due to affinity for mineral and resistance to hydrolytic attack: in vitro data. Calcif. Tissue Int. 58: 45-51.

Boyan, B.D.; Schwartz, Z.; Swain, L.D. and Khare, A. (1989) Role of lipids in calcification of cartilage. Anat. Rec. 224: 211-9.

Brasitus, T.A.; Dahiya, R.; Dudeja, P.K. and Bissonnette, B.M. (1988) Cholesterol modulates alkaline phosphatase activity of rat intestinal microvillus membranes. J. Biol. Chem. 263: 8592-7.

Bratton, D.L. (1994) Polyamine inhibition of transbilayer movement of plasma membrane phospholipids in the erythrocyte ghost. J. Biol. Chem. 269: 22517-23.

Camolezi, F.L.; Daghastanli, K.P.R.; Magalhães, P.P.; Pizauro, J.M. and Ciancaglini, P. (2002) Construction of an alkaline phosphatase-liposome system: a tool for biomineralization study. Int. J. Biochem. Cell Biol. 1282: 1-11.

Carey, M.C. and Small, D.M. (1972) Micelle formation by bile salts. Physical-chemical and thermodynamic considerations. Arch. Intern. Med. 130: 506-27.

Cheng, S.L.; Zhang, S.F. and Avioli, L.V. (1996) Expression of bone matrix proteins during dexamethasone-induced mineralization of human bone marrow stromal cells. J. Cel. Biochem. 61: 182-93.

Ciancaglini, P.; Pizauro, J.M.; Grecchi, M.J.; Curti, C. and Leone, F.A. (1989) Effect of $\mathrm{Zn}(\mathrm{II})$ and $\mathrm{Mg}(\mathrm{II})$ on phosphohydrolitic activity of rat matrix-induced alkaline phosphatase. Cell. Mol. Biol. 35: 503-10.

Ciancaglini, P.; Pizauro, J.M.; Rezende, A.A.; Rezende L.A. and Leone, F.A. (1990a) Solubilization of membrane-bound matrix-induced alkaline phosphatase with polyoxyetylene 9- lauryl ether (polidocanol): purification and metalloenzyme properties. Int. J. Biochem. 22: 385-92.

Ciancaglini, P.; Pizauro, J.M.; Curti, C.; Tedesco, A.C. and Leone, F.A. (1990b) Effect of membrane moiety and magnesium ions on the inhibition of matrix-induced alkaline phosphatase by zinc ions. Int. J. Biochem. 22: 747-51.

Ciancaglini, P.; Simão, A.M.S.; Camolezi, F.L.; Millán, J.L. and Pizauro, J.M. (2006) Contribution of matrix vesicles and alkaline phosphatase to ectopic bone formation. Braz. J. Med. Biol. Res. 39: 603-10. 
Coakley, W.T. (1987) Hyperthermia effects on the cytoskeleton and on cell morphology. Symp. Soc. Exp. Biol. 41: 187-211.

Colbeau, A. and Maroux, S. (1978) Integration of alkaline phosphatase in the intestinal brush border membrane. Biochim. Biophys. Acta 511: 39-51.

Curti, C.; Pizauro J.M.; Rossinholi, G.; Vugman, I.; Mello de Oliveira, J.A. and Leone, F.A. (1986) Isolation and kinetic properties of an alkaline phosphatase from rat bone matrix- induced cartilage. Cell. Mol. Biol. 32: 55-62.

Curti, C.; Pizauro, J.M.; Ciancaglini, P. and Leone, F.A. (1987) Kinetic characteristics of some inhibitors of matrix- induced alkaline phosphatase. Cell. Mol. Biol. 33: 62535.

Cyboron, G.W. and Wuthier, R.E. (1981) Purification and initial characterization of intrinsic membrane-bound alkaline phosphatase from chicken epiphyseal cartilage. J. Biol. Chem. 256: 7262-8.

Cyboron, G.W.; Vejins, M.S. and Wuthier, R.E. (1982) Activity of epiphyseal cartilage membrane alkaline phosphatase and the effects of its inhibitors at physiological pH. J. Biol. Chem. 257: 4141-6.

Daghastanli, K.R.; Ferreira, R.B.; Thedei, G.Jr.; Maggio, B. and Ciancaglini, P. (2004) Lipid composition-dependent incorporation of multiple membrane proteins into liposomes. Colloids Surf. B Biointerfaces 36: 127-37.

Damek-Poprawa, M.; Golub, E.; Otis, L.; Harrison, G.; Phillips, C. and BoeszeBattaglia, K. (2006) Chondrocytes utilize a cholesterol-dependent lipid translocator to externalize phosphatidylserine. Biochemistry 45: 3325-36.

de Bernard, B.; Bianco, P.; Bonucci, E.; Costantini, M.; Lunazzi, G.C.; Martinuzzi, P.; Modricky, C.; Moro, L.; Panfili, E. and Pollesello, P. (1986) Biochemical and immunohistochemical evidence that in cartilage an alkaline phosphatase is a Ca2+-binding glycoprotein. J. Cell. Biol. 103: 1615-23.

de Lima Santos, H.; Lopes, M.L.; Maggio, B. and Ciancaglini, P. (2005) Na,K-ATPase reconstituted in liposomes: effects of lipid composition on hydrolytic activity and enzyme orientation. Colloids Surf. B Biointerfaces 41: 239-48.

Demenis, M.A. and Leone, F.A. (2000) Kinetic characteristics of ATP hydrolysis by a detergent-solubilized alkaline phosphatase from rat osseous plate. IUBMB Life $\underline{49}$ : 113-9.

Derfus, B.; Kranendonk, S.; Camacho, N.; Mandel, N.; Kushnaryov, V.; Lynch, K. and Ryan, L. (1998) Human osteoarthritic cartilage matrix vesicles generate both calcium pyrophosphate dihydrate and apatite in vitro. Calcif. Tissue Int. 63: 258-62.

Di, L.; Liu, W.; Liu, Y. and Wang, J.Y. (2006) Effect of asymmetric distribution of phospholipids in ghost membrane from rat blood on peroxidation induced by ferrous ion. FEBS Lett. 580: 685-90. 
Doberstein, S.K.; Wiegand, G.; Machesky, L.M. and Pollard, T.D. (1995) Fluorescent erythrocyte ghosts as standards for quantitative flow cytometry. Cytometry 20: 148.

Dubreuil, R.R. and Grushko, T. (1998) Genetic studies of spectrin: new life for a ghost protein. Bioessays 20: 875-8.

Eanes, E.D. and Hailer, A.W. (1985) Liposome-mediated calcium phosphate formation in metastable solutions. Calcif. Tissue Int. 37: 390-4.

Eanes, E.D. and Hailer, A.W. (1987) Calcium phosphate precipitation in aqueous suspensions of phosphatidylserine-containing anionic liposomes. Calcif. Tissue Int. 40: 43-8.

Eanes, E.D. (1989) Biophysical aspects of lipid interaction with mineral: liposome model studies. Anat. Rec. 224: 220-5.

Engberts, J.B. and Hoekstra, D. (1995) Vesicle-forming synthetic amphiphiles. Biochim. Biophys. Acta 1241: 323-40.

Fairbanks, G.; Steck, T.L. and Wallach, D.F. (1971) Electrophoretic analysis of the major polypeptides of the human erythrocyte membrane. Biochemistry 10: 260617.

Fallon, M.D.; Whyte, M.P. and Teitelbaum, S.L. (1980) Stereospecific inhibition of alkaline phosphatase by L-tetramisole prevents in vitro cartilage calcification. Lab. Invest. 43: 489-94.

Farquharson, C. and Jefferies, D. (2000) Chondrocytes and longitudinal bone growth: the development of tibial dyschondroplasia. Poult. Sci. $\underline{79}$ : 994-1004.

Ferguson, M.A.J.; Homans, S.W.; Dwek, R.A. and Rademacher, T.W. (1988) Glycosyl-phosphatidylinositol moiety that anchor trypanosoma brucci variant surface glycoprotein to the mebrane. Science 239: 753-9.

Ferrera, D.; Poggi, S.; Biassoni, C.; Dickson, G.R.; Astigiano, S.; Barbieri, O.; Favre, A.; Franzi, A.T.; Strangio, A.; Federici, A. and Manduca, P. (2002) Threedimensional cultures of normal human osteoblasts: proliferation and differentiation potential in vitro and upon ectopic implantation in nude mice. Bone $\underline{30}$ : 718-25.

Fini, C.; Thuong, V.D.; Aliante, M.; Floridi, A. and Cannistraro, S. (1994) Reconstitution of 5'-nucleotidase of bull seminal plasma in spin-labeled liposomes. J. Membr. Biol. 142: 137-44.

Fleisch, H. and Russell, R.G. (1972) A review of the physiological and pharmacological effects of pyrophosphate and diphosphonates on bones and teeth. J. Dent. Res. 51: 324-32.

Fleury, L.; Ollivon, M.; Dubois, J.L.; Puisieux, F. and Barratt, G. (1995) Preparation and characterization of dipalmitoylphosphatidylcholine liposomes containing 
interleukin-2. Braz. J. Med. Biol. Res. 28: 519-29.

Fortuna, R.; Anderson, H.C.; Carty, R. and Sajdera, S.W. (1979) Enzimatic characterization of the chondrocytic alkaline phosphatase isolated from bovine fetal epiphyseal cartilage. Biochim. Biophys. Acta 570: 291-302.

Freemont, A.J. (1993) Basic bone cell biology. Int. J. Exp. Path. 74: 411-6.

Fukushi, M.; Amizuka, N.; Hoshi, K.; Ozawa, H.; Kumagai, H.; Omura, S.; Misumi, Y.; Ikehara, Y. and Oda, K. (1998) Intracellular retention and degradation of tissuenonspecific alkaline phosphatase with a Gly317-->Asp substitution associated with lethal hypophosphatasia. Biochem. Biophys. Res. Commun. 246: 613-8.

Galperin, M.Y.; Bairoch, A. and Koonin, E.V. (1998) A superfamily of metalloenzymes unifies phosphopentomutase and cofactor-independent phosphoglycerate mutase with alkaline phosphatases and sulfatases. Protein Sci. $\underline{7}$ : 1829-35.

Garimella, R.; Bi, X.; Anderson, H.C. and Camacho, N.P. (2006) Nature of phosphate substrate as a major determinant of mineral type formed in matrix vesicle-mediated in vitro mineralization: An FTIR imaging study. Bone $\underline{38}$ : 811-7.

Gennis, R.B. (1989) In: "Biomembranes: molecular structure and function". SpringerYerlag, Ed. Cantor C.R., p. 533.

Gerber, H.P. and Ferrara, N. (2000) Angiogenesis and bone growth. Trends Cardiovasc. Med. 10: 223-8.

Gijsbers, R.; Ceulemans, H.; Stalmans, W. and Bollen, M. (2001) Structural and catalytic similarities between nucleotide pyrophosphatases/phosphodiesterases and alkaline phosphatases. J. Biol. Chem. 276: 1361-8.

Giocondi, M.C.; Besson, F.; Dosset, P.; Milhiet, P.E. and Grimellec, C.L. (2007) Remodeling of ordered membrane domains by GPI-anchored intestinal alkaline phosphatase. Langmuir 23: 9358-64.

Glimcher, M.J. (1987) The nature of the mineral component of bone and the mechanism of calcification. Intr. Course Lect. 36: 49-69.

Gonçalves, R.R.; Furriel, R.P.; Jorge, J.A. and Leone, F.A. (2002) Rat osseous plate alkaline phosphatase: effect of neutral protease digestion on the hydrolysis of pyrophosphate and nitrophenylphosphate. Mol. Cell Biochem. 241: 69-79.

Gowen, L.C.; Petersen, D.N.; Mansolf, A.L.; Qi, H.; Stock, J.L.; Tkalcevic, G.T.; Simmons, H.A.; Crawford, D.T.; Chidsey-Frink, K.L.; Ke, H.Z.; McNeish, J.D. and Brown, T.A. (2003) Targeted disruption of the osteoblast/osteocyte factor 45 gene (OF45) results in increased bone formation and bone mass. J. Biol. Chem. 278: 1998-2007.

Gregoriadis, G. (1990) Immunological adjuvants: a role for liposomes. Immunol. Today 11: 89-97. 
Hamade, E.; Azzar, G.; Radisson, J.; Buchet, R. and Roux, B. (2003) Chick embryo anchored alkaline phosphatase and mineralization process in vitro. Eur. J. Biochem. 270: 2082-90.

Harmey, D.; Hessle, L.; Narisawa, S.; Johnson, K.A.; Terkeltaub, R. and Millán, J.L. (2004) Concerted regulation of inorganic pyrophosphate and osteopontin by Akp2, Enpp1, and Ank. Am. J. Pathol. 164: 1199-209.

Hartree, E.F. (1972) Determination of protein: a modification of the Lowry method that gives a linear photometric response. Anal. Biochem. 48: 422-7.

Hashimoto, S.; Ochs, R.L.; Rosen, F.; Quach, J.; McCabe, G.; Solan, J.; Seegmiller, J.E.; Terkeltaub, R. and Lotz, M. (1998) Chondrocyte-derived apoptotic bodies and calcification of articular cartilage. Proc. Natl. Acad. Sci. USA 95: 3094-9.

Hawrylak, K. and Stinson, R.A. (1987) Tetrameric alkaline phosphatase from human liver is converted to dimer by phosphatidylinositol phospholipase C. FEBS Lett. 212: 289-91.

Heinonen, J.K. and Lahti, R.J. (1981) A new and convenient colorimetric determination of inorganic orthophosphate and its application to the assay of inorganic pyrophosphatase. Anal. Biochem. 113: 313-7.

Helenius, A. and Simons, K. (1975) Solubilization of membranes by detergents. Biochim. Biophys. Acta 415: 29-79.

Helenius, A.; McCaslin, D.R.; Fries, E. and Tanford, C. (1979) Properties of detergents. Methods Enzymol. 트: 734-49.

Henthorn, P.S.; Raducha, M.; Fedde, K.N.; Lafferty, M.A. and Whyte, M.P. (1992) Different missense mutations at the tissue-nonspecific alkaline phosphatase gene locus in autosomal recessively inherited forms of mild and severe hypophosphatasia. Proc. Natl. Acad. Sci. USA 89: 9924-8.

Hessle, L.; Johnson, K.A.; Anderson, H.C.; Narisawa, S.; Sali, A.; Goding, J.W.; Terkeltaub, R. and Millán, J.L. (2002) Tissue-nonspecific alkaline phosphatase and plasma cell membrane glycoprotein-1 are central antagonistic regulators of bone mineralization. Proc. Natl. Acad. Sci. USA 99: 9445-9.

Heywood, B.R. and Eanes, E.D. (1987) An ultrastructural study of calcium phosphate formation in multilamellar liposome suspension. Calcif. Tissue Int. 41: 192-201.

Hillman, R.S. and Finch, C.A. (1996) In: "Red Cell Manual". Ed. Davis, F.A., Philadelphia.

Hjelmeland, L.M. (1980) A nondenaturing zwitterionic detergent for membrane biochemistry: design and synthesis. Proc. Natl. Acad. Sci. USA 77: 6368-70.

Ho, A.M.; Johnson, M.D. and Kingsley, D.M. (2000) Role of the mouse ank gene in control of tissue calcification and arthritis. Science 289: 265-70. 
Holloway, P.W. (1973) A simple procedure for removal of Triton X-100 from protein samples. Anal. Biochem. 53: 304-8.

Horigome, T. and Sugano, H. (1983) A rapid method for removal of detergents from protein solution. Anal. Biochem. 130: 393-6.

Horikawa, S. and Ocawara, H. (1979) A simple and rapid procedure for removal of Triton X-100 from protein solution. Anal. Biochem. 97: 116-9.

Houston, B.; Seawright, E.; Jefferies, D.; Hoogland, E.; Lester, D.; Whitehead, C. and Farquharson, C. (1999) Identification and cloning of a novel phosphatase expressed at high levels in differentiating growth plate chondrocytes. Biochim. Biophys. Acta 1448: 500-6.

Houston, B.; Stewart, A.J. and Farquharson, C. (2004) PHOSPHO1-A novel phosphatase specifically expressed at sites of mineralization in bone and cartilage. Bone 34: 629-37.

Howard, A.D.; Berger, J.; Gerber, L.; Familletti, P. and Udenfriend, S. (1987) Characterization of the phosphatidylinositol-glycan membrane anchor of human placental alkaline phosphatase. Proc. Natl. Acad. Sci. USA 84: 6055-9.

Hsu, H.H.T. and Anderson, H.C. (1977) A simple and defined method to study calcification by isolated matrix vesicles. Effect of ATP and vesicles phosphatase. Biochim. Biophys. Acta 500: 162-72.

Hsu, H.H.T. and Anderson, H.C. (1978) Calcification of isolated matrix vesicles and reconstituted vesicles from fetal bovine cartilage. Proc. Natl. Acad. Sci. USA $\underline{75}$ : 3805-8.

Hsu, H.H.T.; Munoz, P.A.; Barr, J.; Oppliger, I.; Morris, D.C.; Vaananem, H.K.; Tarkenton, N. and Anderson, H.C. (1985) Purification and partial characterization of alkaline phosphatase of matrix vesicles from fetal bovine epiphyseal cartilage. J. Biol. Chem. 260: 1826-31.

Hsu, H.H.T and Anderson, H.C. (1986) The deposition of calcium pyrophosphate by NTP pyrophosphohydrolase of matrix vesicles from fetal bovine epiphyseal cartilage. Int. J. Biochem. 18: 1141-6.

Hsu, H.H.T. (1994) Mechanisms of initiating calcification. ATP-stimulated Ca- and Pidepositing activity of isolated matrix vesicles. Int. J. Biochem. 26: 1351-6.

Hsu, H.H.T. and Anderson, H.C. (1995) A role for ATPase in the mechanisms of ATP-dependent $\mathrm{Ca}$ and phosphate deposition by Isolated rachictic matrix vesicles. Int. J. Biochem. 27: 1349-56.

Huang, R.; Rosenbach, M.; Vaughn, R.; Provvedini, D.; Rebbe, N.; Hickman, S.; Goding, J. and Terkeltaub, R. (1994) Expression of the murine plasma cell nucleotide pyrophosphohydrolase $\mathrm{PC}-1$ is shared by human liver, bone, and cartilage cells. Regulation of PC-1 expression in osteosarcoma cells by 
transforming growth factor-beta. J. Clin. Invest. $\underline{94:}$ 560-7.

Ibaraki, K.; Termine, J.D.; Whitson, S.W. and Young, M.F. (1992) Bone matrix mRNA expression in differentiating fetal bovine osteoblasts. J. Bone Miner. Res. 7: 74354.

lerardi, D.F.; Pizauro, J.M. and Ciancaglini, P. (2002) Erythrocyte ghost cell- alkaline phosphatase: construction and characterization of a vesicular system for use in biomineralization studies. Biochim. Biophys. Acta 1567: 183-92.

Itving, J.T. (1973) Theories of mineralization of bone. Clin. Orthop. 97: 225-36.

Iwaki-Egawa, S. and Ihler, G.M. (1997) Comparison of the abilities of proteins from Bartonella bacilliformis and Bartonella henselae to deform red cell membranes and to bind to red cell ghost proteins. FEMS Microbiol. Lett. 157: 207-17.

Jackson, J.K.; Winternitz, C.I. and Burt, H.M. (1996) Mechanism of hemolysis of human erythrocytes exposed to monosodium urate monohydrate crystals. Preliminary characterization of membrane pores. Biochim. Biophys. Acta 1281: 4552.

Jefferies, D.; Houston, B.; Lester, D.; Whitehead, C.C.; Thorp, B.H.; Botman, M. and Farquharson, C. (2000) Expression patterns of chondrocyte genes cloned by differential display in tibial dyschondroplasia. Biochim. Biophys. Acta 1501: 180-8.

Johnson, K.; Moffa, A.; Chen, Y.; Pritzker, K.; Goding, J. and Terkeltaub, R. (1999) Matrix vesicle plasma cell membrane glycoprotein-1 regulates mineralization by murine osteoblastic MC3T3 cells. J. Bone Miner. Res. 14: 883-92.

Johnson, K.A.; Hessle, L.; Vaingankar, S.; Wennberg, C.; Mauro, S.; Narisawa, S.; Goding, J.W.; Sano, K.; Millán, J.L. and Terkeltaub, R. (2000) Osteoblast tissuenonspecific alkaline phosphatase antagonizes and regulates PC-1. Am. J. Physiol. Regul. Integr. Comp. Physiol. 279: R1365-R1377.

Kagawa, Y.; Kandrach, A. and Racker, E. (1973) Partial resolution of the enzymes catalyzing oxidative phosphorylation. XXVI. Specificity of phospholipids required for energy transfer reactions. J. Biol. Chem. 248: 676-84.

Kihn, L.; Rutkowski, D. and Stinson, R.A. (1990) Incorporation of human and placental alkaline phosphatase into liposomes and membranes is via phosphatidylinositol. Biochem. Cell. Biol. 68: 1112-8.

Kirsch, T. and Wuthier, R.E. (1994) Stimulation of calcification of growth plate cartilage matrix vesicles by binding to type II and X collagens. J. Biol. Chem. 269: 11462-9.

Kirsch, T.; Nah, H.D.; Shapiro, I.M. and Pacifici, M. (1997) Regulated production of mineralization-competent matrix vesicles in hypertrophic chondrocytes. J. Cell Biol. 137: 1149-60. 
Kirsch, T.; Nah, H.D.; Demuth, D.R.; Harrison, G.; Golub, E.E.; Adams, S.L. and Pacifici, M. (1997) Annexin V-mediated calcium flux across membranes is dependent on the lipid composition: implications for cartilage mineralization. Biochemistry 36: 3359-67.

Kirsch, T.; Harrison, G.; Golub, E.E. and Nah, H.D. (2000) The roles of annexins and types II and $X$ collagen in matrix vesicle-mediated mineralization of growth plate cartilage. J. Biol. Chem. 275: 35577-83.

Koboki, Y.; Takita, H.; Komori, T.; Mizumo, M.; Furu-Uchi, E. and Taniguchi, K. (1989) Separation of bone matrix-proteins by calcium-induced preparation. Calcif. Tissue Int. 44: 269-77.

Koepsell, H. (1986) Methodological aspects of purification and reconstitution of transport proteins from mammalian plasma membranes. Rev. Physiol. Biochem. Pharmacol. 104: 65-137.

Kozlenkov, A.; Le Du, M.H.; Cuniasse, P.; Ny, T.; Hoylaerts, M.F. and Millán, J.L. (2004) Residues determining the binding specificity of uncompetitive inhibitors to tissue-nonspecific alkaline phosphatase. J. Bone Miner. Res. 19: 1862-72.

Kriebardis, A.G.; Antonelou, M.H.; Stamoulis, K.E.; Economou-Petersen, E.; Margaritis, L.H. and Papassideri, I.S. (2007) Progressive oxidation of cytoskeletal proteins and accumulation of denatured hemoglobin in stored red cells. J. Cell. Mol. Med. 11: 148-55.

Krug, H.E.; Mahowald, M.L.; Halverson, P.B.; Sallis, J.D. and Cheung, H.S. (1993) Phosphocitrate prevents disease progression in murine progressive ankylosis. Arthritis Rheum. 36: 1603-11.

Kunitake, T.; Okahata, Y.; Tamaki, K.; Kumamaru, F. and Takayanagi, M. (1977) Formation of the bilayer membrane from a series of quaternary ammonium salts. Chem. Lett.: 387-90.

Laemmli, U.K. (1970) Cleavage of structural proteins during the assembly of the head bacteriophage T4. Nature (London) 227: 680-5.

Le Du, M.H.; Stigbrand, T.; Taussig, M.J.; Menez, A. and Stura, E.A. (2001) Crystal structure of alkaline phosphatase from human placenta at $1.8 \AA$ resolution. Implication for a substrate specificity. J. Biol. Chem. 276: 9158-65.

Le Du, M.H. and Millán, J.L. (2002) Structural evidence of functional divergence in human alkaline phosphatases. J. Biol. Chem. 277: 49808-14.

Lehto, M.T. and Sharom, F.J. (1998) Release of the glycosylphosphatidylinositolanchored enzyme ecto-5'-nucleotidase by phospholipase $\mathrm{C}$ : catalytic activation and modulation by the lipid bilayer. Biochem. J. 332: 101-9.

Lehto, M.T. and Sharom, F.J. (2002a) PI-specific phospholipase C cleavage of a reconstituted GPI-anchored protein: modulation by the lipid bilayer. Biochemistry 
41: 1398-408.

Lehto, M.T. and Sharom, F.J. (2002b) Proximity of the protein moiety of a GPIanchored protein to the membrane surface: a FRET study. Biochemistry $\underline{41}$ : 836876 .

Lejeune, A.; Moorjani, M.; Gicquaud, C.; Lacroix, J.; Poyet, P. and Gaudreault, R. (1997) Nanoerythrosome, a new derivative of erythrocyte ghost: III. Is phagocytosis involved in the mechanism of action? Anticancer Res. 17: 3599-603.

Leone, F.A.; Pizauro, J.M. and Ciancaglini, P. (1992) Effect of pH on the modulation of rat osseous plate alkaline phosphatase by metal ions. Int. J. Biochem. 24: 9238.

Leone, F.A.; Pizauro, J.M. and Ciancaglini, P. (1997a) Rat osseous plate alkaline phosphatase: a search for its role in biomineralization. Trends Comp. Biochem. Physiol. ㅁ: 57-73.

Leone, F.A.; Rezende, L.A.; Ciancaglini, P. and Pizauro, J.M. (1998) Allosteric modulation of pyrophosphatase activity of rat osseous plate alkaline phosphatase by magnesium ions. Int. J. Biochem. Cell. Biol. 30: 89-97.

Leone, F.A.; Baranauskas, J.A.; Furriel, R.P.M. and Borin, I.A. (2005) SigrafW: An easy-to-use program for fitting enzyme kinetic data. Biochem. Mol. Ed. 33: 399403.

Levy, D.; Gulik, A.; Bluzat, A. and Rigaud, J.L. (1992) Reconstitution of the sarcoplasmic reticulum $\mathrm{Ca}(2+)$-ATPase: mechanisms of membrane protein insertion into liposomes during reconstitution procedures involving the use of detergents. Biochim. Biophys. Acta 1107: 283-98.

Liu, C.; Marshall, P.; Schreibman, I.; Vu, A.; Gai, W. and Whitlow, M. (1999) Interaction between terminal complement proteins $\mathrm{C} 5 \mathrm{~b}-7$ and anionic phospholipids. Blood 93: 2297-301.

López Cascales, J.J.; Otero, T.F.; Smith, B.D.; González, C. and Márquez, M. (2006) Model of an asymmetric DPPC/DPPS membrane: effect of asymmetry on the lipid properties. A molecular dynamics simulation study. J. Phys. Chem. B 110: 235863.

Loveridge, N. and Farquharson, C. (1993) Studies on growth plate chondrocytes in situ: cell proliferation and differentiation. Acta Paediatr. Suppl. 391: 42-8.

Low, M.G. and Finean, J.B. (1978) Specific release of plasma membrane enzymes by a phosphatidylinositol-specific phospholipase C. Biochim. Biophys. Acta $\underline{508}$ : 565-70.

Low, M.G.; Ferguson, M.A.J.; Futerman, A.H. and Silman, I. (1986) Covalently attached phosphatidylinositol ia a hidrophobic anchor for membrane proteins. Trends. Biochem. Sci. 11: 212-5. 
Low, M.G.; Futerman, A.H.; Ackermann, K,E.; Sherman, W.R. and Silman, I. (1987) Removal of covalently bound inositol from torpedo acetylcholinesterase and mammalian alkaline phosphatases by deamination with nitrous acid. Evidence for a common membrane-anchoring structure. Biochem. J. 241: 615-9.

Low, M.G. and Saltiel, A.R. (1988) Structural and functional roles of glycosylphosphatidylinositol in membranes. Science 239: 268-75.

Lowe, M.K.; Strauss, A.W.; Alpers, R. and Seetharam, S. (1990) Molecular clone and expression of cDNA encoding the membrane-associated rat intestinal alkaline phosphatase. Biochem. Biophys. Acta 1037: 170-7.

Magnani, M.; Rossi, L.; Fraternale, A.; Bianchi, M.; Antonelli, A.; Crinelli, R. and Chiarantini, L. (2002) Erythrocyte-mediated delivery of drugs, peptides and modified oligonucleotides. Gene Ther. 9: 749-51.

Magne, D.; Bluteau, G.; Faucheux, C.; Palmer, G.; Vignes-Colombeix, C.; Pilet, P.; Rouillon, T.; Caverzasio, J.; Weiss, P.; Daculsi, G. and Guicheux, J. (2003) Phosphate is a specific signal for ATDC5 chondrocyte maturation and apoptosisassociated mineralization: possible implication of apoptosis in the regulation of endochondral ossification. J. Bone Miner. Res. 18: 1430-42.

Majeska, R.J. and Wuthier, R.E. (1975) Studies on matrix vesicles isolated from chick epiphyseal cartilage. Association of pyrophosphatase and ATPase activities with alkaline phosphatase. Biochim. Biophys. Acta 391: 51-60.

Mansfield, K.; Rajpurohit, R. and Shapiro I.M. (1999) Extracellular phosphate ions cause apoptosis of terminally differentiated epiphyseal chondrocytes. J. Cell Physiol. 179: 276-86.

Mansfield, K.; Teixeira, C.C.; Adams, C.S. and Shapiro, I.M. (2001) Phosphate ions mediate chondrocyte apoptosis through a plasma membrane transporter mechanism. Bone 28: 1-8.

Mansfield, K.; Pucci, B.; Adams, C.S. and Shapiro, I.M. (2003) Induction of apoptosis in skeletal tissues: phosphate-mediated chick chondrocyte apoptosis is calcium dependent. Calcif. Tissue Int. 73: 161-72.

Marie, M.; Champeil, P. and Moller, J.V. (2000) Interaction of membrane proteins and lipids with solubilizing detergents. Biochim. Biophys. Acta 1508: 86-111.

Martino, L.J.; Yeager, V.L. and Taylor, J.J. (1979) An ultrastructural study of the role of calcification nodules in the mineralization of woven bone. Calcif. Tissue Int. 27: 57-64.

Marx, R.E.; Carlson, E.R.; Eichstaedt, R.M.; Schimmele, S.R.; Strauss, J.E. and Georgeff, K.R. (1998) Platelet-rich plasma: Growth factor enhancement for bone grafts. Oral Surg. Oral Med. Oral Pathol. Oral Radiol. Endod. 85: 638-46.

McComb, R.B.; Bowers, G.N. and Posen, S. (1979) In: "Alkaline phosphatase". 
Plenum Press, New York.

Messer, H.H.; Rogers, J.; Shami, Y. and Copp, D.H. (1975) Ca-2+, Mg-2+-activated ATPase and alkaline phosphatase of developing chick femora. Comp. Biochem. Physiol. B. 51: 19-24.

Meyer, J.L. (1984) Can biological calcification occur in the presence of pyrophosphate? Arch. Biochem. Biophys. 231: 1-8.

Meyer, J.L. and Reddi, A.H. (1985) Changes in pyrophosphatase activity during the de novo mineralization associated with cartilage and bone formation. Arch. Biochem. Biophys. 242: 532-9.

Michel, M.; Winterhalter, M.; Darbois, L.; Hemmerle, J.; Voegel, J.C.; Schaaf, P. and Ball, V. (2004) Giant liposome microreactors for controlled production of calcium phosphate crystals. Langmuir 20: 6127-33.

Millán, C.G.; Marinero, M.L.; Castañeda, A.Z. and Lanao, J.M. (2004) Drug, enzyme and peptide delivery using erythrocytes as carriers. J. Control. Release 95: 27-49.

Millán, J.L. (2006) In: "Mammalian Alkaline Phosphatases: From Biology to Applications in Medicine and Biotechnology". Wiley-VCH Verlag GmbH \& Co. KGaA, Weinheim.

Morandat, S.; Bortolato, M. and Roux, B. (2002) Cholesterol-dependent insertion of glycosylphosphatidylinositol-anchored enzyme. Biochim. Biophys. Acta 1564: 4738.

Morandat, S.; Bortolato, M. and Roux, B. (2003) Role of GPI-anchored enzyme in liposome detergent-resistance. J. Membr. Biol. 191: 215-21.

Mornet, E.; Stura, E.; Lia-Baldini, A.S.; Stigbrand, T.; Ménez, A. and Le Du, M.H. (2001) Structural evidence for a functional role of human tissue nonspecific alkaline phosphatase in bone mineralization. J. Biol. Chem. 276: 31171-8.

Morris, D.C.; Masuhara, K.; Takaoka, K.; Ono, K. and Anderson, H.C. (1992) Immunolocalization of alkaline phosphatase in osteoblasts and matrix vesicles of human fetal bone. Bone Miner. 19: 287-98.

Moss, D.W. and Walli, A.K. (1969) Intermediates in the hydrolysis of ATP by human alkaline phosphatase. Biochim. Biophys. Acta 191: 476-7.

Moss, D.W.; Eaton, R.H.; Smith, J.K. and Whitby, L.G. (1967) Association of inorganic-pyrophosphatase activity with human alkaline-phosphatase preparations. Biochem. J. 102: 53-7.

Murphy, W. and Messersmith, P.B. (2000) Compartmental control of mineral formation: adaptation of a biomineralization strategy for biomedical use. Polyhedron 19: 357-63. 
Murshed, M.; Harmey, D.; Millán, J.L.; McKee, M.D. and Karsenty, G. (2005) Unique coexpression in osteoblasts of broadly expressed genes accounts for the spatial restriction of ECM mineralization to bone. Genes Dev. 19: 1093-104.

Nakamura, T.; Nakamura, K. and Stinson, R.A. (1988) Release of alkaline phosphatase from human osteosarcoma cell by phosphatidylinositol phospholipase C: effect of tunicamycin. Arch. Biochem. Biophys. 265: 190-6.

Nakano, Y.; Addison, W.N. and Kaartinen, M.T. (2007) ATP-mediated mineralization of MC3T3-E1 osteoblast cultures. Bone 41: 549-61.

New, R.R.C. (1990) In: "Liposomes: a practical approach". Oxford University Press, NY.

Nosjean, O. and Roux, B. (1999) Ectoplasmic insertion of a glycosylphosphatidylinositol-anchored protein in glycosphingolipid- and cholesterol-containing phosphatidylcholine vesicles. Eur. J. Biochem. 263: 865-70.

Nürnberg, P.; Thiele, H.; Chandler, D.; Höhne, W.; Cunningham, M.L.; Ritter, H.; Leschik, G.; Uhlmann, K.; Mischung, C.; Harrop, K.; Goldblatt, J.; Borochowitz, Z.U.; Kotzot, D.; Westermann, F.; Mundlos, S.; Braun, H.S.; Laing, N. and Tinschert, S. (2001) Heterozygous mutations in ANKH, the human ortholog of the mouse progressive ankylosis gene, result in craniometaphyseal dysplasia. Nat. Genet. 28: 37-41.

O'Brien, P.J. and Herschlag, D. (2001) Functional interrelationships in the alkaline phosphatase superfamily: phosphodiesterase activity of Escherichia coli alkaline phosphatase. Biochemistry $\underline{40}$ : 5691-9.

Ochoa, E.R. and Vacanti, J.P. (2002) An overview of the pathology and approaches to tissue engineering. Ann. N. Y. Acad. Sci. 979: 10-26.

Okawa, A.; Nakamura, I.; Goto, S.; Moriya, H.; Nakamura, Y. and Ikegawa, S. (1998) Mutation in Npps in a mouse model of ossification of the posterior longitudinal ligament of the spine. Nat. Genet. 19: 271-3.

Osyczka, A.M. and Leboy, P.S. (2005) Bone morphogenetic protein regulation of early osteoblast genes in human marrow stromal cells is mediated by extracellular signal-regulated kinase and phosphatidylinositol 3-kinase signaling. Endocrinology 146: 3428-37.

Owen, T.A.; Aronow, M.; Shalhoub, V.; Barone, L.M.; Wilming, L.; Tassinari, M.S.; Kennedy, M.B.; Pockwinse, S.; Lian, J.B. and Stein, G.S. (1990) Progressive development of the rat osteoblast phenotype in vitro: reciprocal relationships in expression of genes associated with osteoblast proliferation and differentiation during formation of the bone extracellular matrix. J. Cell. Physiol. 143: 420-30.

Petersen, D.N.; Tkalcevic, G.T.; Mansolf, A.L.; Rivera-Gonzalez, R. and Brown, T.A. (2000) Identification of osteoblast/osteocyte factor 45 (OF45), a bone-specific cDNA encoding an RGD-containing protein that is highly expressed in osteoblasts 
and osteocytes. J. Biol. Chem. 275: 36172-80.

Phinney, D.G. (2002) Building a consensus regarding the nature and origin of mesenchymal stem cells. J. Cel. Biochem. Sup. 38: 7-12.

Picher, M. and Boucher, R.C. (2001) Metabolism of extracellular nucleotides in human airways by a multienzyme system. Drug Dev. Res. 52: 66-75.

Picher, M.; Burch, L.H.; Hirsh, A.J.; Spychala, J. and Boucher, R.C. (2003) Ecto 5'nucleotidase and nonspecific alkaline phosphatase. Two AMP-hydrolyzing ectoenzymes with distinct roles in human airways. J. Biol. Chem. 278: 13468-79.

Pizauro, J.M.; Curti, C.; Ciancaglini, P. and Leone, F.A. (1987) Triton X-100 solubilized bone matrix-induced alkaline phosphatase. Comp. Biochem. Physiol. 87B: 921-6.

Pizauro, J.M.; Curti, C.; Ciancaglini, P. and Leone, F.A. (1988) Kinetic properties of Triton X-100 solubilized bone matrix induced alkaline phosphatase. Cell. Mol. Biol. 34: 553-62.

Pizauro, J.M.; Ciancaglini, P. and Leone, F.A. (1992) Phosphotransferase activity associated with rat osseous plates alkaline phosphatase: a possible role in biomineralization. Int. J. Biochem. 24: 1391-6.

Pizauro, J.M.; Ciancaglini, P. and Leone, F.A. (1993) Allosteric modulation by ATP, calcium and magnesium ions of rat osseous plate alkaline phosphatase. Biochem. Biophys. Acta 1202: 22-8.

Pizauro, J.M.; Ciancaglini, P. and Leone, F.A. (1994) Osseous plate alkaline phosphatase is anchored by GPI. Braz. J. Med. Biol. Res. 27: 453-6.

Pizauro, J.M.; Ciancaglini, P. and Leone F.A. (1995) Characterization of the phosphatidylinositol-specific phospholipase C-released form of rat osseous plate alkaline phosphatase and its possible significance on endochondral ossification. Mol. Cel. Biochem. 152: 121-9.

Pizauro, J.M.; Demenis, M.A.; Ciancaglini, P. and Leone, F.A. (1998) Kinetic characterizatian of membrane-specific ATPase from rat osseous plate and its possible significance on endochondral ossification. Biochim. Biophys. Acta 1368: 108-14.

Pizauro, J.M.; Ciancaglini, P. and Macari, M. (2002) Tibial Dyschondroplasia: mechanisms of the lesion and control. Poult. Sci. $\underline{3}$ : 169-85.

Poole, A.R.; Mitsui, Y.; Hinek, A. and Lee, E.R. (1989) Cartilage macromolecules and the calcification of cartilage matrix. Anat. Rec. 224: 167-79.

Prasad, R. (1996) Manual of membrane lipids. Ed. Prasad, R. (Springer-Verlag Berli Heidelderg). 
Privé, G.G. (2007) Detergents for the stabilization and crystallization of membrane proteins. Methods. 41: 388-97.

Prockop, D.J.; Gregory, C.A. and Spees, J.L. (2003) One strategy for cell and gene therapy: harnessing the power of adult stem cells to repair tissues. Proc. Natl. Acad. Sci. USA 100: 11917-23.

Radisson, J.; Angrand, M.; Chavassieux, P.; Roux, B. and Azzar, G. (1996) Differential solubilization of osteoblastic alkaline phosphatase from human primary bone cell cultures. Int. J. Biochem. Cell Biol. 28: 421-30.

Read, S.M. and Northcote, D.H. (1981) Minimization of variation in the response to different proteins of the Comassie blue $G$ dye-binding assay for protein. Anal. Biochem. 116: 53-64.

Reddi, A.H. and Huggins, C. (1972) Biochemical sequences in the transformation of normal fibriloblast in adolescent rat. Proc. Natl. Acad. Sci. USA 69: 1601-5.

Register, T.C.; Gregory, P.W. and Wuthier, R.E. (1984) Effect on L- and Dtetramisole on ${ }^{32} \mathrm{Pi}$ and ${ }^{45} \mathrm{Ca}$ uptake and mineralization by matrix vesicle-enriched fractions from chicken epiphyseal cartilage. J. Biol. Chem. 259: 922-8.

Register, T.C.; McLean, F.M.; Low, M.G. and Wuthier, R.E. (1986) Roles of alkaline phosphatase and labile internal mineral in matrix vesicle-mediated calcification. Effect of selective release of membrane-bound alkaline phosphatase and treatment with isosmotic pH 6 buffer. J. Biol. Chem. 261: 9354-60.

Rezende, A.A.; Petenusci, S.O.; Urbinati, E.C. and Leone, F.A. (1993) Kinetic properties of osseous plate alkaline phosphatase from diabetic rats. Comp. Biochem. Physiol. 104A: 469-74.

Rezende, A.A.; Pizauro, J.M.; Ciancaglini, P. and Leone, F.A. (1994) Phosphodiesterase activity is a novel property of alkaline phosphatase from osseous plate. Biochem. J. 301: 517-22.

Rezende, A.A.; Pizauro, J.M.; Ciancaglini, P. and Leone, F.A. (1998) Inorganic pyrophosphate-phosphohydrolytic activity associated with rat osseous plate alkaline phosphatase. Cel. Mol. Biol. 44: 293-302.

Rigaud, J.L.; Pitard, B. and Levy, D. (1995) Reconstitution of membrane proteins into liposomes: application to energy-transducing membrane proteins. Biochim. Biophys. Acta 1231: 223-46.

Rigos, C.F.; de Lima Santos, H.; Ward, R.J. and Ciancaglini, P. (2006) Lipid bilayer stabilization of the Na,K-ATPase reconstituted in DPPC/DPPE liposomes. Cell Biochem. Biophys. 44: 438-45.

Roberts, S.J.; Stewart, A.J.; Sadler, P.J. and Farquharson, C. (2004) Human PHOSPHO1 exhibits high specific phosphoethanolamine and phosphocholine phosphatase activities. Biochem. J. 382: 59-65. 
Roberts, S.; Narisawa, S.; Harmey, D.; Millán, J.L. and Farquharson, C. (2007) Functional involvement of $\mathrm{PHOSPHO} 1$ in matrix vesicle-mediated skeletal mineralization. J. Bone Miner. Res. 22: 617-27.

Robison, R. (1923) The possible significance of hexosephosphoric esters in ossification. Biochem. J. 17: 286-93.

Rongen, H.A.H.; Bult, A. and van Bennekom, W.P. (1997) Liposomes and immunoassays. J. Immunol. Methods 204: 105-33.

Ronzon, F.; Desbat, B.; Chauvet, J.P. and Roux, B. (2002) Behavior of a GPIanchored protein in phospholipid monolayers at the air-water interface. Biochim. Biophys. Acta 1560: 1-13.

Ronzon, F.; Morandat, S.; Roux, B. and Bortolato, M. (2004) Insertion of a glycosylphosphatidylinositol-anchored enzyme into liposomes. J. Membr. Biol. 197: 169-77.

Rowe, P.S.; de Zoysa, P.A.; Dong, R.; Wang, H.R.; White, K.E.; Econs, M.J. and Oudet, C.L. (2000) MEPE, a new gene expressed in bone marrow and tumors causing osteomalacia. Genomics $\underline{67}$ : 54-68.

Rutsch, F.; Vaingankar, S.; Johnson, K.; Goldfine, I.; Maddux, B.; Schauerte, P.; Kalhoff, H.; Sano, K.; Boisvert, W.A.; Superti-Furga, A. and Terkeltaub, R. (2001) PC-1 nucleoside triphosphate pyrophosphohydrolase deficiency in idiopathic infantile arterial calcification. Am. J. Pathol. 158: 543-54.

Santos, H.L. and Ciancaglini, P. (2000) A practical approach to the choice of a suitable detergent and optimal conditions to solubilize a membrane protein. BAMBED 28: 178-82.

Santos, F.R.; Ferraz, D.B.; Daghastanli, K.R.; Ramalho-Pinto, F.J. and Ciancaglini, P. (2006) Mimetic membrane system to carry multiple antigenic proteins from Leishmania amazonensis. J. Membr. Biol. 210: 173-81.

Say, J.C.; Ciuffi, K.; Furriel, R.P.M.; Ciancaglini, P. and Leone, F.A. (1991) Alkaline phosphatase from rat osseous plates: purification and biochemical characterization of a soluble form. Biochim. Biophys. Acta 1074: 256-62.

Schreier, H.; Moran, P. and Caras, I.W. (1994) Targeting of liposomes to cells expressing CD4 using glycosylphosphatidylinositol-anchored gp120. Influence of liposome composition on intracellular trafficking. J. Biol. Chem. 269: 9090-8.

Schroeder, R.; London, E. and Brown, D. (1994) Interactions between saturated acyl chains confer detergent resistance on lipids and glycosylphosphatidylinositol (GPI)-anchored proteins: GPI-anchored proteins in liposomes and cells show similar behavior. Proc. Natl. Acad. Sci. USA 91: 12130-4.

Seetharam, B.; Tiruppathi, C. and Alpers, D.H. (1987) Hydrophobic interactions of brush border alkaline phosphatases: the role of phosphatidylinositol. Arch. 
Biochem. Biophys. 253: 189-98.

Sela, J.; Gross, U.M.; Kohavi, D.; Shani, J.; Dean, D.D.; Boyan, B.D. and Schwartz, Z. (2000) Primary mineralization at the surfaces of implants. Crit. Rev. Oral Biol. Med. 11: 423-36.

Shapiro, I.M.; Adams, C.S.; Freeman, T. and Srinivas, V. (2005) Fate of the hypertrophic chondrocyte: microenvironmental perspectives on apoptosis and survival in the epiphyseal growth plate. Birth Defects Res. C Embryo Today $\underline{75}$ : $330-9$.

Sharom, F.J.; McNeil, G.L.; Glover, J.R. and Seier, S. (1996) Modulation of the cleavage of glycosylphosphatidylinositol-anchored proteins by specific bacterial phospholipases. Biochem. Cell. Biol. 74: 701-13.

Sharom, F.J. and Lehto, M.T. (2002) Glycosylphosphatidylinositol-anchored proteins: structure, function, and cleavage by phosphatidylinositol-specific phospholipase C. Biochem. Cell. Biol. 80: 535-49.

Shibata, H.; Fukushi, M.; Igarashi, A.; Misumi, Y.; Ikehara, Y.; Ohashi, Y. and Oda, K. (1998) Defective intracellular transport of tissue-nonspecific alkaline phosphatase with an Ala162-->Thr mutation associated with lethal hypophosphatasia. J. Biochem. 123: 968-77.

Silvius, J.R. (1992) Solubilization and functional reconstitution of biomembrane components. Annu. Rev. Biophys. Biomol. Struct. 21: 323-48.

Simão, A.M.S.; Beloti, M.M.; Cezarino, R.M.; Rosa, A.L.; Pizauro, J.M. and Ciancaglini, P. (2007a) Membrane-bound alkaline phosphatase from ectopic mineralization and rat bone marrow cell culture. Comp. Biochem. Physiol. A Mol. Integr. Physiol. 146: 679-87.

Simão, A.M.S.; Beloti, M.M.; Rosa, A.L.; de Oliveira, P.T.; Granjeiro, J.M.; Pizauro, J.M. and Ciancaglini, P. (2007b) Culture of osteogenic cells from human alveolar bone: a useful source of alkaline phosphatase. Cell Biol. Int. 31: 1405-13.

Skrtic, D. and Eanes, E.D. (1992) Effect of membrane cholesterol on calcium phosphate formation in aqueous suspensions of anionic liposomes. Calcif. Tissue Int. 50: 55-60.

Skrtic, D. and Eanes, E.D. (1992) Effect of different phospholipid-cholesterol membrane compositions on liposome-mediated formation of calcium phosphates. Calcif. Tissue Int. 50: 253-60.

Skrtic, D. and Eanes, E.D. (1992) Membrane-mediated precipitation of calcium phosphate in model liposomes with matrix vesicle-like lipid composition. Bone Miner. 16: 109-19.

Smith, E.L.; Hill, R.L.; Lehman, I.R.; Lefkowitz, R.J.; Handler, P. and White, A. (1983) In: "Bioquímica de mamíferos". Ed. Guanabara Koogan, pp. 64-68. 
Steck, T.L.; Weinstein, R.S.; Straus, J.H. and Wallach, D.F. (1970) Inside-out red cell membrane vesicles: preparation and purification. Science 168: 255-7.

Stein, G.S.; Lian, J.B. and Owen, T.A. (1990) Relationship of cell growth to the regulation of tissue-specific gene expression during osteoblast differentiation. FASEB J. 13: 3111-23.

Stewart, A.J.; Schmid, R.; Blindauer, C.A.; Paisey, S.J. and Farquharson, C. (2003) Comparative modelling of human $\mathrm{PHOSPHO} 1$ reveals a new group of phosphatases within the haloacid dehalogenase superfamily. Protein Eng. 16: 88995.

Stewart, A.J.; Roberts, S.J.; Seawright, E.; Davey, M.G.; Fleming, R.H. and Farquharson, C. (2006) The presence of PHOSPHO1 in matrix vesicles and its developmental expression prior to skeletal mineralization. Bone 39: 1000-7.

Takesue, Y.; Yokota, K.; Mirajima, S.; Taguchi, Y. and Ikezawa, H. (1989) Membrane anchors of alkaline phosphatase and trehalase associated with the plasma membrane of larval midgut epithelial cells of the silkworm, bombyx mori. J. Biochem. 105: 998-1001.

Takeuchi, M.; Miyamoto, H.; Sako, Y.; Komizu, H. and Kusumi, A. (1998) Structure of the erythrocyte membrane skeleton as observed by atomic force microscopy. Biophys. J. 74: 2171-83.

Terkeltaub, R.A. (2001) Inorganic pyrophosphate generation and disposition in pathophysiology. Am. J. Physiol. Cell Physiol. 281: C1-C11.

Tzagaloff, A. and Penefsky, H.S. (1971) Extraction and purification of lipoprotein complex from membranes. Methods Enzymol. 22: 219-30.

Urist, M.R.; Iwata, H.; Ceccotti, P.L.; Dorfman, R.L.; Boyd, S.D.; McDowell, R.M. and Chien, C. (1973) Bone morphogenesis in implants of insoluble bone gelatin. Proc. Natl. Acad. Sci. USA 70: 3511-5.

van den Dolder, J. and Cansen, J.A. (2007) Enrichment of osteogenic cell populations from rat bone marrow stroma. Biomaterials 28: 249-55.

Vemuri, S. and Rhodes, C.T. (1995) Preparation and characterization of liposomes as therapeutic delivery systems: a review. Pharm. Acta Helv. 70: 95-111.

Vince, J.W. and Reithmeier, R.A. (1998) Carbonic anhydrase II binds to the carboxyl terminus of human band 3, the erythrocyte $\mathrm{C} 1-/ \mathrm{HCO} 3-$ exchanger. J. Biol. Chem. 273: 28430-7.

Vogel, J.J. (1986) The membrane interface in biologic calcification. In: "Cell Mediated Calcification and Matrix Vesicles". (Ed. Ali, S.Y.), pp. 181-5. Elsevier Sciences Publishers B.V. Amsterdam.

Wang, W.; Xu, J. and Kirsch, T. (2003) Annexin-mediated Ca2+ influx regulates 
growth plate chondrocyte maturation and apoptosis. J. Biol. Chem. 278: 3762-9.

Wang, W.; Xu, J.; Du, B. and Kirsch, T. (2005) Role of the progressive ankylosis gene (ank) in cartilage mineralization. Mol. Cell. Biol. 25: 312-23.

Warren, G.B.; Toon, P.A.; Birdsall, N.J.; Lee, A.G. and Metcalfe, J.C. (1974) Reconstitution of a calcium pump using defined membrane components. Proc. Natl. Acad. Sci. USA 71: 622-6.

Watt, F.M. (1986) The extracellular matrix and cells shape. Tibs. 11: 482-5.

Whyte, M.P. (1995) Hypophosphatasia. In: C.R. Scriver, A.L. Beaudet, W.S. Sly, D. Valle (eds.) The metabolic and molecular bases of inherited disease, 7th ed. McGraw-Hill New York, pp. 4095-4112.

Wu, L.N.Y.; Genge, B.R.; Dunkelberger, D.G.; LeGeros, R.Z.; Concannon, B. and Wuthier, R.E. (1997) Physicochemical characterization of the nucleational core of matrix vesicles. J. Biol. Chem. 272: 4404-11.

Wu, L.N.; Genge, B.R.; Kang, M.W.; Arsenault, A.L. and Wuthier, R.E. (2002) Changes in phospholipid extractability and composition accompany mineralization of chicken growth plate cartilage matrix vesicles. J. Biol. Chem. 277: 5126-33.

Wuthier, R.E. (1975) Lipid composition of isolated epiphyseal cartilage cells membranes and matrix vesicles. Biochim. Biophys. Acta 409: 128-43.

Wuthier, R.E. (1977) Electrolytes of isolated epiphyseal chondrocytes, matrix vesicles, and extracellular fluid. Calcif. Tissue Res. 23: 125-33.

Wuthier, R.E. (1982) A review of the primary mechanism of endochondral calcification with special emphasis on role of cells, mitochondria and matrix vesicles. Clin. Orthop. 169: 219-42.

Wuthier, R.E. (1986) Mechanism of matrix vesicles mediated mineralization. In: "Cell Mediated Calcification and Matrix-Vesicles". (Ali, S.Y. ed.) Elsevier Sciencies Publishers B.V. Amsterdam, pp. 47-55.

Wuthier, R.E. and Register, T.C. (1985) Role of alkaline phosphatase, a polifunctional enzyme, in mineralizing tissues. In: "The chemistry and biology of mineralized tissues". (Butler, W.T. ed.) EBSCO Média Inc. Birgmingham pp. 11324.

Wuthier, R.E.; Bisaz, S.; Russell, R.G. and Fleisch, H. (1972) Relationship between pyrophosphate, amorphous calcium phosphate and other factors in the sequence of calcification in vivo. Calcif. Tissue Res. 10: 198-206.

Wuthier, R.E.; Chin, J.E.; Hole, J.E.; Register, T.C.; Laura, Y.H. and Ishikawa, Y. (1985) Isolation and characterization of calcium accumuling matrix vesicles from chondrocytes of chicken epiphsyeal growth plate cartilage in primary culture. J. Biol. Chem. 260: 15972-9. 
Yamaguchi, T.; Ozaki, S.; Shimomura, T. and Terada, S. (2007) Membrane perturbations of erythrocyte ghosts by spectrin release. J. Biochem. 141: 747-54.

Yeagle, P.L. (1993) Phosphorus-31 nuclear magnetic resonance in membrane fusion studies. Methods Enzymol. 220: 68-79.

Zhang, L.; Balcerzak, M.; Radisson, J.; Thouverey, C.; Pikula, S.; Azzar, G. and Buchet, R. (2005) Phosphodiesterase activity of alkaline phosphatase in ATPinitiated $\mathrm{Ca}^{2+}$ and phosphate deposition in isolated chicken matrix vesicles. J. Biol. Chem. 280: 37289-96.

Zurutuza, L.; Muller, F.; Gibrat, J.F.; Taillandier, A.; Simon-Bouy, B.; Serre, J.L. and Mornet, E. (1999) Correlations of genotype and phenotype in hypophosphatasia. Hum. Mol. Genet. ㅇ: 1039-46. 
Anexos

7. Anexos 


\section{Contribution of matrix vesicles and alkaline phosphatase to ectopic bone formation}

P. Ciancaglini ${ }^{1}$, A.M.S. Simão ${ }^{1}$, F.L. Camolezi ${ }^{1}$, J.L. Millán ${ }^{2}$ and J.M. Pizauro ${ }^{3}$

\author{
'Departamento de Química, Faculdade de Filosofia, \\ Ciências e Letras de Ribeirão Preto, Universidade de São Paulo, \\ Ribeirão Preto, SP, Brasil \\ 2The Burnham Institute, La Jolla, CA, USA \\ ${ }^{3}$ Departamento de Tecnologia, Faculdade de Ciências Agrárias e Veterinárias de \\ Jaboticabal, Universidade Estadual Paulista, Jaboticabal, SP, Brasil
}

\section{Correspondence \\ P. Ciancaglini \\ Departamento de Química \\ Faculdade de Filosofia, Ciências \\ e Letras de Ribeirão Preto, USP \\ 14040-901 Ribeirão Preto, SP \\ Brasil \\ Fax: +55-16-36024838 \\ E-mail: pietro@ffclrp.usp.br}

Research supported in part by FAPESP and CNPq, and by grants DE 12889 and AR 47908 from the National Institutes of Health, USA.

Received June 17, 2005

Accepted January 13, 2006

\begin{abstract}
Endochondral calcification involves the participation of matrix vesicles (MVs), but it remains unclear whether calcification ectopically induced by implants of demineralized bone matrix also proceeds via MVs. Ectopic bone formation was induced by implanting rat demineralized diaphyseal bone matrix into the dorsal subcutaneous tissue of Wistar rats and was examined histologically and biochemically. Budding of MVs from chondrocytes was observed to serve as nucleation sites for mineralization during induced ectopic osteogenesis, presenting a diameter with Gaussian distribution with a median of $306 \pm 103$ $\mathrm{nm}$. While the role of tissue-nonspecific alkaline phosphatase (TNAP) during mineralization involves hydrolysis of inorganic pyrophosphate $\left(\mathrm{PP}_{\mathrm{i}}\right)$, it is unclear how the microenvironment of MV may affect the ability of TNAP to hydrolyze the variety of substrates present at sites of mineralization. We show that the implants contain high levels of TNAP capable of hydrolyzing p-nitrophenylphosphate (pNPP), ATP and $\mathrm{PP}_{\mathrm{i}}$. The catalytic properties of glycosyl phosphatidylinositol-anchored, polidocanol-solubilized and phosphatidylinositol-specific phospholipase C-released TNAP were compared using pNPP, $\mathrm{ATP}$ and $\mathrm{PP}_{\mathrm{i}}$ as substrates. While the enzymatic efficiency $\left(k_{\text {cat }} / K_{\mathrm{m}}\right)$ remained comparable between polidocanol-solubilized and membrane-bound TNAP for all three substrates, the $k_{\mathrm{cat}} / K_{\mathrm{m}}$ for the phosphatidylinositol-specific phospholipase C-solubilized enzyme increased approximately 108-, 56-, and 556-fold for pNPP, ATP and $\mathrm{PP}_{\mathrm{i}}$, respectively, compared to the membrane-bound enzyme. Our data are consistent with the involvement of MVs during ectopic calcification and also suggest that the location of TNAP on the membrane of MVs may play a role in determining substrate selectivity in this micro-compartment.
\end{abstract}

Key words

- Matrix vesicles

- Endochondral ossification

- Osseous plate

- Alkaline phosphatase

- Ectopic mineralization

- Calcification 


\section{Introduction}

Biological calcification is a tightly regulated process in which different types of tissues, cells, organelles, and biomolecules participate in the coordination and regulation of metabolic events involved in accumulating calcium phosphate (1-7).

Bone formation can be reproduced experimentally by the subcutaneous implantation of demineralized bone matrix, a procedure that leads to the sequential development of cartilage and bone $(8,9)$. The ectopic implantation of bone morphogenetic proteins (10) also leads to osteogenesis but by a mechanism that is unclear. Elucidating the molecular mechanisms controlling ectopic bone formation is of paramount interest because understanding these mechanisms will enable the partial or de novo reconstruction of bone tissue (11) and contribute to the establishment of therapeutic strategies for bone diseases.

We have studied ectopic bone formation, including some of the enzymes $(9,12-14)$ and lipids present in membranes of cells and/or organelles associated with this process $(15,16)$. There is good evidence that endochondral calcification involves the participations of matrix vesicles (MVs) $(7,17$, 18 ), but it is not clear whether calcification of ectopically implanted demineralized bone matrix also proceeds via MVs. According to several investigators, these extracellular organelles capable of mineral accumulation bud by exocytosis from the plasma membrane and serve as the site of primary mineralization in the matrix of bone, cartilage and dentin (4,7,17-22).

Electron microscope studies have indicated that biological calcification occurs in the MVs in two steps, the first related to the initial deposition of hydroxyapatite within the lumen of the MVs and the second to the propagation of mineral outside the vesicles $(2-4,18)$. Tissue-nonspecific alkaline phosphatase (TNAP) has been shown to be highly enriched in MVs $(17,18)$. TNAP's function in bone mainly relates to its ability to hydrolyze inorganic pyrophosphate $\left(\mathrm{PP}_{\mathrm{i}}\right)$, a potent mineralization inhibitor, while simultaneously producing $\mathrm{P}_{\mathrm{i}}$, which as a byproduct is available for deposition as hydroxyapatite $(23,24)$. Studies on MVs isolated from hypophosphatasia patients (25) or from knockout mice deficient in TNAP (26) have indicated that the first steps of mineralization remain intact in the MVs, while it is the propagation step that is severely affected in the absence of TNAP.

In the present study, we demonstrate the presence of functional MVs in the initial stages of ectopic mineralization caused by subcutaneous implantation of decalcified bone matrix. We also show that the kinetic properties of TNAP vary greatly in the presence or absence of diacylglycerol or other membrane components, suggesting that its location on MVs during mineralization may be a factor that contributes to establishing substrate specificity.

\section{Material and Methods}

\section{Material}

All aqueous solutions were made using Millipore (Bedford, MA, USA) MilliQ ultra-pure apyrogenic water. Bovine serum albumin, Tris hydroxymethyl amino methane (Tris), 2-amino-2-methyl-propan-1-ol (AMPOL), trichloroacetic acid, N-(2-hydroxyethyl) piperazine-N'-ethenesulfonic acid, adenosine 5'-triphosphate disodium salt (ATP), sodium dodecylsulfate, p-nitrophenylphosphate (pNPP), and polyoxyethylene 9 lauryl ether $\left(\mathrm{C}_{12} \mathrm{E}_{9}\right.$ - polidocanol $)$ were from Sigma (St. Louis, MO, USA). Analytical grade reagents were used without further purification.

\section{Preparation of rat osseous plate}

Adult Wistar rats of both sexes, weighing 
$350-400 \mathrm{~g}$, were killed by decapitation and the muscle-free thigh bones were removed and demineralized according to Reddi and Huggins (8). Briefly, diaphyseal bones were dehydrated and grounded in 0.125 to $0.175 \mathrm{~mm}$ fragments, treated with $0.5 \mathrm{M} \mathrm{HCl}$ in a proportion of $25 \mathrm{mM} \mathrm{HCl} / \mathrm{g}$ bone, with constant stirring and $100 \mathrm{~mA}$ of alternating current for $3 \mathrm{~h}$ at $25^{\circ} \mathrm{C}$. Finally, the remaining bone matrix was exhaustively washed using distilled water and newly dehydrated. Ten to twenty milligrams of rat demineralized diaphyseal bone matrix was introduced through a small incision in the dorsal subcutaneous tissue of anesthetized young male Wistar rats (50-60 g). Fourteen days after implantation (the period required for the development of maximal alkaline phosphatase activity), the newly formed plate was removed, rinsed in ice-cold $0.9 \%(\mathrm{w} / \mathrm{v}) \mathrm{NaCl}$, and used for microscopical examination and for alkaline phosphatase extraction (15).

\section{Electron microscopy}

The growth plate obtained after 14 days of induction was sectioned $(1 \mu \mathrm{m})$ and incubated in $0.1 \mathrm{M}$ phosphate buffer, $\mathrm{pH} 7.3$, containing $3 \%(\mathrm{w} / \mathrm{v})$ glutaraldehyde for $1 \mathrm{~h}$, followed by incubation with $1 \%(\mathrm{w} / \mathrm{v})$ osmium solution prepared in the same buffer. After $1 \mathrm{~h}$, the sample was washed in $0.1 \mathrm{M}$ sodium phosphate buffer, $\mathrm{pH} 7.3$, centrifuged and dehydrated with acetone/water mixtures of increasing acetone concentration and the final dehydration was accomplished by 3 washes with $100 \%$ acetone for $10 \mathrm{~min}$. Finally, the pellet was embedded in (1:1) araldite resin at $37^{\circ} \mathrm{C}$ for $48 \mathrm{~h}$ and in pure araldite for $72 \mathrm{~h}$ at $60^{\circ} \mathrm{C}$. Thin sections were cut using a microtome and stained with $1 \%(\mathrm{w} / \mathrm{v})$ Toluidine blue and ultrafine sections $(0.5 \mu \mathrm{m})$ were mounted on copper gilder grids (200 mesh). Finally, they were stained with $4 \%$ (w/v) uranyl acetate, $\mathrm{pH} 12$, for 10 min followed by $0.3 \%(\mathrm{w} / \mathrm{v})$ lead citrate, $\mathrm{pH}$ 12, for $10 \mathrm{~min}$. The sample was examined using a Philips (Model 208; Prague, Czecho- slovakia) transmission electron microscope.

\section{Preparation of rat osseous plate alkaline phosphatase}

An osseous plate membrane fraction rich in alkaline phosphatase, polidocanol-solubilized and phosphatidylinositol-specific phospholipase C (PIPLC)-released alkaline phosphatase was prepared as described by Camolezi et al. (15). Briefly, 14 days after implantation, the growth plate formed was removed, rinsed in ice-cold $0.9 \%(\mathrm{w} / \mathrm{v}) \mathrm{NaCl}$ and homogenized with $10 \mathrm{mM}$ Tris/ $\mathrm{HCl}$ buffer, $\mathrm{pH} 7.5$, containing $0.15 \mathrm{M} \mathrm{NaCl}(3 \mathrm{~mL}$ buffer/g osseous plate) in a high-speed shearing homogenizer, for $2 \mathrm{~min}$. The homogenate (crude extract enzyme) was centrifuged at $15,000 \mathrm{~g}$ for $20 \mathrm{~min}$ and the supernatant was dialysed overnight, at $4^{\circ} \mathrm{C}$, against 5 $\mathrm{mM}$ Tris/ $\mathrm{HCl}$ buffer, $\mathrm{pH} 7.5$, containing 2 $\mathrm{mM} \mathrm{MgCl}$ and $0.15 \mathrm{M} \mathrm{NaCl}$. The dialysed homogenate was centrifuged for $1 \mathrm{~h}$ at $160,000 \mathrm{~g}$. The pellet, corresponding to the membrane-bound enzyme was resuspended in $5 \mathrm{mM}$ Tris/HCl buffer, $\mathrm{pH} 7.5$, containing $2 \mathrm{mM} \mathrm{MgCl}$. Samples of membrane fraction $(0.2 \mathrm{mg} / \mathrm{mL})$ were treated with $1 \%$ polidocanol for $1 \mathrm{~h}$ with constant stirring at $25^{\circ} \mathrm{C}$ or aliquots $(2 \mathrm{mg} / \mathrm{mL})$ were incubated with 0.1 U PIPLC from $B$. thuringiensis for $1 \mathrm{~h}$ under constant stirring at $25^{\circ} \mathrm{C}$. Both samples were centrifuged at $100,000 \mathrm{~g}$ for 1 $\mathrm{h}$, at $4^{\circ} \mathrm{C}$. The supernatants were the source of solubilized or enzymatically released alkaline phosphatase, respectively.

\section{Enzymatic activity measurements}

p-Nitrophenylphosphatase (pNPPase), adenosine-5'-triphosphatase (ATPase) and pyrophosphatase ( $\mathrm{PP}_{\mathrm{i}}$ ase) activities were assayed as described by Camolezi et al. (15). Briefly, pNPPase activity was assayed discontinuously at $37^{\circ} \mathrm{C}$ in a Spectronic (Genesys 2 ) spectrophotometer by following the liberation of p-nitrophenolate ion (1 M $\varepsilon, \mathrm{pH}$ 
9.4, $17,600 \mathrm{M}^{-1} \mathrm{~cm}^{-1}$ ) at $410 \mathrm{~nm}$. Standard conditions were $50 \mathrm{mM}$ AMPOL buffer, $\mathrm{pH}$ 9.4, containing $2 \mathrm{mM} \mathrm{MgCl} 2$ and $1 \mathrm{mM}$ pNPP in a final volume of $1.0 \mathrm{~mL}$. The reaction was initiated by the addition of the enzyme and stopped with $1.0 \mathrm{~mL}$ of $1.0 \mathrm{M}$ $\mathrm{NaOH}$ at appropriate time intervals. For ATPase, the activity was also assayed discontinuously by measuring the amount of inorganic phosphate liberated, adjusting the assay medium to a final volume of $1.0 \mathrm{~mL}$. The reaction was initiated by the addition of the enzyme, stopped with $0.5 \mathrm{~mL}$ of cold $30 \%$ trichloroacetic acid at appropriate time intervals. The reaction mixtures were centrifuged at 4,000 $\mathrm{g}$ prior to phosphate determi-

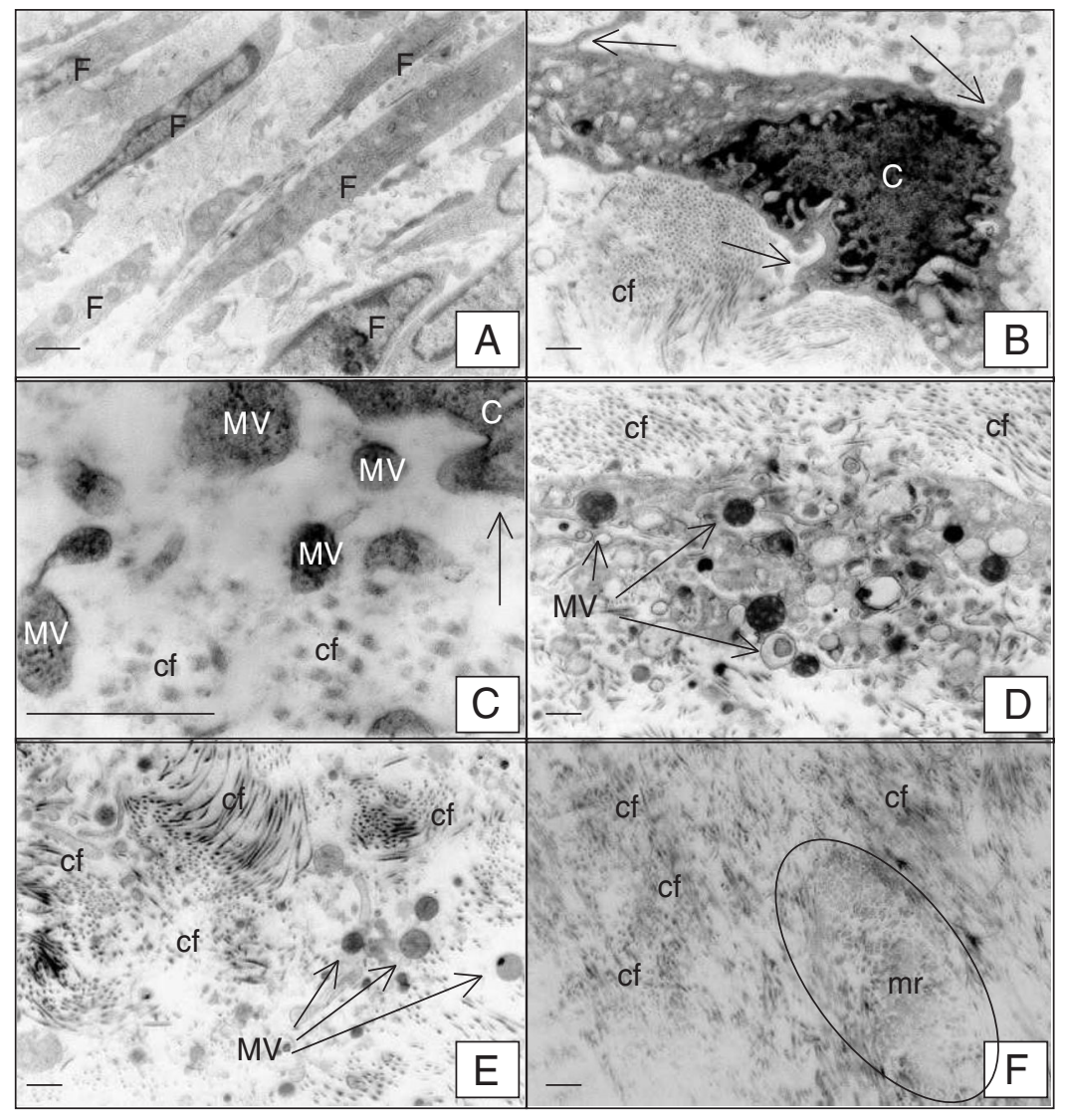

Figure 1. Mineralization was induced by implanting demineralized rat diaphyseal bone matrix into the dorsal subcutaneous tissue of young male Wistar rats. Fourteen days postimplantation the tissue was removed and processed for electron microscopy as described in Material and Methods. A, Fibroblast "F"; $B$, chondrocyte "C"; $B$ and $C$ details of matrix vesicles (MV) budding from chondrocyte membrane (arrows); $D$ and $E$, extracellular MV and collagen fibers "cf"; $F$, stage of advanced mineralization ("mr" indicates mineralization region previously occupied by hypertrophic chondrocytes). Bars correspond to $500 \mathrm{~nm}$. nation. Standard assay conditions were 50 mM AMPOL buffer, $\mathrm{pH} 9.4$, containing 2 $\mathrm{mM} \mathrm{MgCl}_{2}$ and $2 \mathrm{mM}$ ATP. For $\mathrm{PP}_{\mathrm{i}}$ ase activity assays, standard conditions were 50 $\mathrm{mM}$ Tris/ $\mathrm{HCl}$ buffer, $\mathrm{pH} 8.0$, containing 2 $\mathrm{mM} \mathrm{MgCl}_{2}$ and $2 \mathrm{mM}$ sodium pyrophosphate, and processes performed as described for ATPase activity.

All determinations were carried out in triplicate and the initial velocities were constant for at least 90 min provided that less than $5 \%$ of the substrate was hydrolyzed. Controls without added enzyme were included in each experiment to account for the non-enzymatic hydrolysis of substrate.

\section{Determination of kinetic parameters}

Maximum velocity, catalytic constant $\left(k_{\text {cat }}\right)$, apparent dissociation constant $\left(K_{0.5}\right)$, and Hill coefficient obtained from substrate hydrolysis were calculated using the software described by Leone et al. (27). Data are reported as the mean of triplicate measurements of three different enzyme preparations, which was considered to be statistically significant at $\mathrm{P} \leq 0.05$.

\section{Statistical analysis}

Kinetic data were submitted to analysis of variance in a completely randomized design and differences between means were verified by the Tukey test $(\mathrm{P}<0.05)$.

\section{Results and Discussion}

Ectopic bone formation can be reproduced experimentally by implantation of demineralized bone matrix (8) or by implantation of morphogenic proteins at ectopic sites (10). This process permits clear visualization of a sequence of mineral nucleating events in the osteoid, in the absence of an established mineralizing front (28). In particular, implantation of decalcified bone matrix triggers the cascade leading to endo- 
chondral bone formation. The histological profile of the tissue 14 days after implantation of demineralized bone indicates the presence of fibroblasts and chondrocytes. The 14-day endpoint was chosen because TNAP activity of the implant was maximal at this stage (9). By means of electron microscopy, fibroblasts (Figure 1A), hypertrophic chondrocytes (Figure 1B), osteoblasts can be identified in the specimens in agreement with previous studies $(8,9,11,28,29)$. The presence of fibroblasts has been considered a characteristic of the initial stages of the calcification process while chondrocytes are characteristic of later stages $(8,9,14)$. The histological profile of the implanted demineralized bone matrix 14 days after implantation of bone matrix shows typical features of the later stage of endochondral osteogenesis, namely bone and cartilage (Figure 1F).

We found MVs budding from chondrocytes (see Figure 1C and E) and the presence of collagen fibers in the extracellular matrix (Figure 1E). Many chondrocyte-derived MVs appeared to serve as nucleation sites for mineralization during induced ectopic osteogenesis as they contained needle-like crystals consistent with hydroxyapatite (Figure 1D and E). These vesicles had a Gaussian size distribution of 150 to $600 \mathrm{~nm}$ with a median of $306 \pm 103 \mathrm{~nm}$ (Figure 2). This median diameter is similar to that reported by us and others during mineralization of epiphyseal cartilage as well as in cultured chondrocytes $(7,30,31)$. This wide size distribution may indicate that more than one type of MV exist. However, it is as yet unknown whether a single cell produces multiple sub-classes of MVs at a specific stage of differentiation or if each cell produces only one class of MV $(30,31)$.

The implants contained high levels of TNAP capable of hydrolyzing pNPP, ATP and $\mathrm{PP}_{\mathrm{i}}$ (Table 1). Since TNAP is not the only enzyme present in the membrane $(4,13$, 14,19,32-37) the enzymatic studies were carried out using isolated membrane-bound, polidocanol-solubilized and also PIPLC-released TNAP. There were significant differences $(\mathrm{P}<0.05)$ in terms of substrate utilization by the different purified TNAP preparations. The PIPLC-solubilized enzyme displays approximately a 700 -fold increase in

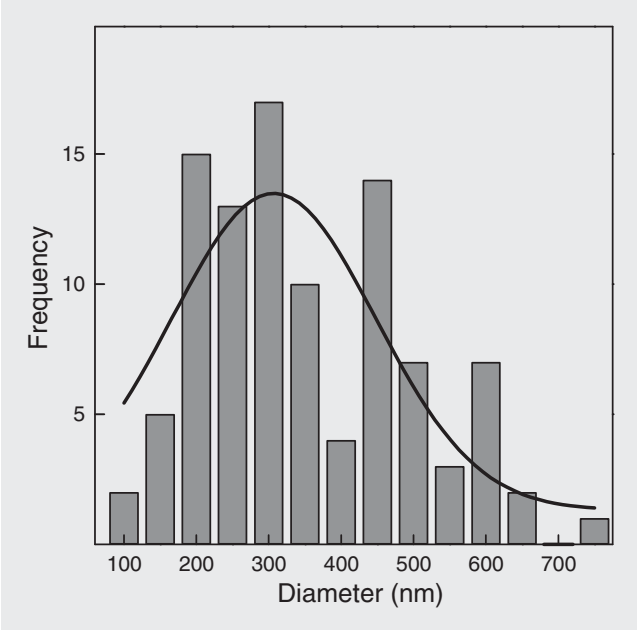

Figure 2. Gaussian distribution of the diameter of 100 matrix vesicles determined from electron micrographs of 14-day-old mineralized implants.

Table 1. Kinetic parameters of tissue-nonspecific alkaline phosphatase present in the matrix vesicles acting on different substrates.

\begin{tabular}{|c|c|c|c|c|c|c|c|c|c|c|}
\hline \multirow[t]{2}{*}{ Substrate } & \multirow[t]{2}{*}{$\mathrm{pH}$} & \multicolumn{2}{|c|}{ Membrane fraction } & \multirow{2}{*}{$\begin{array}{l}k_{\text {cat }} / K_{m} \\
\left(\mathrm{M}^{-1} \mathrm{~s}^{-1}\right)\end{array}$} & \multicolumn{2}{|c|}{ Polidocanol-solubilized } & \multirow{2}{*}{$\begin{array}{l}k_{\text {cat }} / K_{m} \\
\left(\mathrm{M}^{-1} \mathrm{~s}^{-1}\right)\end{array}$} & \multicolumn{2}{|c|}{ PIPLC-solubilized } & \multirow{2}{*}{$\begin{array}{l}k_{\text {cat }} / K_{\mathrm{m}} \\
\left(\mathrm{M}^{-1} \mathrm{~s}^{-1}\right)\end{array}$} \\
\hline & & $k_{\text {cat }}\left(\mathrm{s}^{-1}\right)$ & $K_{\mathrm{m}}(\mathrm{M})$ & & $k_{\text {cat }}\left(\mathrm{s}^{-1}\right)$ & $K_{\mathrm{m}}(\mathrm{M})$ & & $k_{\text {cat }}\left(\mathrm{s}^{-1}\right)$ & $K_{\mathrm{m}}(\mathrm{M})$ & \\
\hline pNPP & 9.4 & 0.79 & $1.0 \times 10^{-4}$ & $7.3 \times 10^{4}$ & 2.21 & $4.1 \times 10^{-5}$ & $5.5 \times 10^{4}$ & $550.2^{*}$ & $7.0 \times 10^{-5}$ & $7.9 \times 10^{6}$ \\
\hline ATP & 9.4 & 1.23 & $1.5 \times 10^{-4}$ & $8.2 \times 10^{3}$ & 0.65 & $0.9 \times 10^{-5}$ & $7.2 \times 10^{3}$ & $59.2^{*}$ & $1.3 \times 10^{-4}$ & $4.6 \times 10^{5}$ \\
\hline $\mathrm{PP}_{\mathrm{i}}$ & 8.0 & 0.23 & $1.4 \times 10^{-3}$ & $1.6 \times 10^{2}$ & 0.52 & $1.1 \times 10^{-3}$ & $4.7 \times 10^{2}$ & $87.5^{\star}$ & $9.8 \times 10^{-4}$ & $8.9 \times 10^{4}$ \\
\hline
\end{tabular}

Preparations were buffered with $50 \mathrm{mM}$ 2-amino-2-methyl-propan-1-ol containing different concentrations of substrates as described in Material and Methods. Data are reported as the mean of triplicate measurement of three different enzyme preparations. PIPLC = phosphatidylinositolspecific phospholipase C; $k_{\text {cat }}=$ catalytic constant; $K_{\mathrm{m}}=$ dissociation constant; pNPP $=$ p-nitrophenylphosphate; ATP $=$ adenosine-5'-triphosphate; $\mathrm{PP}_{\mathrm{i}}=$ pyrophosphate.

${ }^{*} \mathrm{P}<0.05$ compared to membrane fraction (Tukey test). 
$k_{\text {cat }}$ for pNPP, 48-fold for ATP and 380-fold for $\mathrm{PP}_{\mathrm{i}}$ with respect to the membrane-bound enzyme. However, comparing the polidocanol-solubilized enzyme to the membranebound enzyme the values for $k_{\text {cat }}$ barely changed and even decreased as in the case of ATP. Furthermore, while the enzymatic efficiency $\left(k_{\mathrm{cat}} / K_{\mathrm{m}}\right)$ remained comparable between the polidocanol-solubilized and the membrane-bound enzyme for all three substrates, the value for $k_{\mathrm{cat}} / K_{\mathrm{m}}$ for the PIPLCsolubilized enzyme $(\mathrm{P}<0.05)$ increased approximately 108-, 56-, and 556-fold for pNPP, ATP and $\mathrm{PP}_{\mathrm{i}}$, respectively, compared to the membrane-bound enzyme. Since TNAP is anchored to the membrane by a phosphatidylinositol moiety $(13,33)$, this suggests that the catalytic efficiency of TNAP is strongly affected by diacylglycerol or by molecules binding to it.

These data are relevant to interpreting studies aimed at understanding the functional consequences of mutations in TNAP known to cause hypophosphatasia $(36,38$, $39)$. We recently reported that several hypophosphatasia mutations in mice displayed selectivity towards $\mathrm{PP}_{\mathrm{i}}$ versus pyridoxal-5'phosphate, another natural substrate of the enzyme, and that this selectivity could explain in part the variable expressivity of epileptic seizures in patients harboring those mutations (36). We have also recently obtained experimental evidence to support the previous contention that the primary role of TNAP in bone is to hydrolyze $\mathrm{PP}_{\mathrm{i}}$, a potent inhibitor of hydroxyapatite deposition, thus helping to restrict the pool of extracellular $\mathrm{PP}_{\mathrm{i}}$ and ensure proper mineralization $(24,40)$. The main source of $\mathrm{PP}_{\mathrm{i}}$ at the level of MVs is the pyrophosphohydrolase activity of NPP1 that converts extracellular ATP into AMP and $\mathrm{PP}_{\mathrm{i}}$. However, TNAP, which co-localizes with NPP1 on the MVs, hydrolyzes
ATP to produce ADP and $\mathrm{P}_{\mathrm{i}}$ while being affected allosterically by ATP (33) and being subjected to competitive inhibition by the product of this reaction, i.e., $\mathrm{P}_{\mathrm{i}}$. In turn, both ADP and AMP can also serve as substrates of TNAP. Thus, the relative concentrations of ATP, ADP, AMP, $\mathrm{PP}_{\mathrm{i}}$, and $\mathrm{P}_{\mathrm{i}}$ will have an influence on TNAP function. Our data suggest that the location of TNAP on the membrane of MVs may play a role in determining substrate selectivity in this micro-compartment. These data also suggest that assays of TNAP mutants bound to MVs or to liposome-based systems may be more biologically relevant than assays done on solubilized enzyme preparations.

We have shown here that the ectopic mineralization process induced by ectopic implantation of demineralized bone matrix occurs via an MV-mediated mechanism analogous to that of endochondral ossification. The MVs contain high levels of TNAP able to function as ATPase and pyrophosphatase, although the kinetics towards the substrates is greatly affected by the presence of diacylglycerol moieties and other cell membrane components. It is still unclear if the size and localization of the MVs may further affect the kinetic properties of TNAP but studies in this regard should further our understanding of the biological role of this enzyme during bone mineralization and better explain the abnormalities caused by different hypophosphatasia mutations.

\section{Acknowledgments}

The authors thank Mrs. Priscila Cerviglieri for reviewing the text. We also thank Maria Dolores S. Ferreira, Faculdade de Medicina de Ribeirão Preto, USP, for the electron microscopy work. 


\section{References}

1. Blumenthal NC (1989). Mechanism of inhibition and calcification. Clinical Orthopaedics and Related Research, 247: 279-289.

2. Poole AR, Mitsui $Y$, Hinek A et al. (1989). Cartilage macromolecules and the calcification of cartilage matrix. Anatomical Record, 224: 167-179.

3. Freemont AJ (1993). Basic bone cell biology. International Journal of Experimental Pathology, 74: 411-416.

4. Anderson HC (1995). Molecular biology of matrix vesicles. Clinical Orthopaedics and Related Research, 314: 266-280.

5. Hsu HHT \& Anderson HC (1995). A role for ATPase in the mechanisms of ATP-dependent $\mathrm{Ca}$ and phosphate deposition by isolated rachitic matrix vesicles. International Journal of Biochemistry, 27: 1349-1356.

6. Boyan BD, Schwartz Z \& Boskey AL (2000). The importance of mineral in bone and mineral research. Bone, 27: 341-342.

7. Kirsch T, Wang W \& Pfander D (2003). Functional differences between growth plate apoptotic bodies and matrix vesicles. Journal of Bone and Mineral Research, 18: 1872-1881.

8. Reddi AH \& Huggins CB (1972). Biochemical sequences in the transformation of normal fibroblasts in adolescent rats. Proceedings of the National Academy of Sciences, USA, 69: 1601-1605.

9. Curti C, Pizauro JM, Rossinholi G et al. (1986). Isolation and kinetic properties of an alkaline phosphatase from rat bone matrix-induced cartilage. Cellular and Molecular Biology, 32: 55-62.

10. Urist MR, Iwata H, Ceccotti PL et al. (1973). Bone morphogenesis in implants of insoluble bone gelatin. Proceedings of the National Academy of Sciences, USA, 70: 3511-3515.

11. Reddi AH (2000). Initiation and promotion of endochondral bone formation by bone morphogenetic proteins: potential implications for avian tibial dyschondroplasia. Poultry Science, 9: 978-981.

12. Ciancaglini P, Pizauro JM, Rezende AA et al. (1990). Solubilization of membrane-bound matrix-induced alkaline phosphatase with polyoxyethylene 9-lauryl ether (polidocanol): purification and metalloenzyme properties. International Journal of Biochemistry, 22: 385392.

13. Pizauro JM, Ciancaglini P \& Leone FA (1995). Characterization of the phosphatidylinositol-specific phospholipase C-released form of rat osseous plate alkaline phosphatase and its possible significance on endochondral ossification. Molecular and Cellular Biochemistry, 152: 121-129.

14. Leone FA, Pizauro JM \& Ciancaglini P (1997). Rat osseous plate alkaline phosphatase: a search for its role in biomineralization. Trends in Comparative Biochemistry and Physiology, 3: 57-73.

15. Camolezi FL, Daghastanli KRP, Magalhães PP et al. (2002). Construction of an alkaline phosphatase-liposome system: a tool for biomineralization study. International Journal of Biochemistry and Cell Biology, 34: 1091-1101.

16. Ierardi DF, Pizauro JM \& Ciancaglini P (2002). Erythrocyte ghost cell-alkaline phosphatase: construction and characterization of a vesicular system for use in biomineralization studies. Biochimica et Biophysica Acta, 1567: 183-192.

17. Ali SY, Sajdera SW \& Anderson HC (1970). Isolation and characterization of calcifying matrix vesicles from epiphyseal cartilage. Proceedings of the National Academy of Sciences, USA, 67: 15131520.

18. Ali SY, Anderson HC \& Sajdera SW (1971). Enzymic and electronmicroscopic analysis of extracellular matrix vesicles associated with calcification in cartilage. Biochemical Journal, 122: 1-56.
19. Anderson HC (2003). Matrix vesicles and calcification. Current Rheumatology Reports, 5: 222-226.

20. Ali SY \& Evans $L$ (1973). The uptake of ${ }^{45} \mathrm{Ca}$ ions by matrix vesicles isolated from calcifying cartilage. Biochemical Journal, 134: 647650.

21. Schwartz Z, Schlader DL, Swain LD et al. (1998). Direct effects of 1,25-dihydroxyvitamin $D_{3}$ and 24,25-dihydroxyvitamin $D 3$ on growth zone and resting zone chondrocyte membrane alkaline phosphatase and phospholipase-A2 specific activities. Endocrinology, 1: 28782884.

22. Hoshi K \& Ozawa H (2000). Matrix vesicle calcification in bones of adult rats. Calcified Tissue International, 66: 430-434.

23. Rezende AA, Pizauro JM, Ciancaglini P et al. (1994). Phosphodiesterase activity is a novel property of alkaline phosphatase from osseous plate. Biochemical Journal, 301: 517-522.

24. Hessle L, Johnsson KA, Anderson HC et al. (2002). Tissue-nonspecific alkaline phosphatase and plasma cell membrane glycoprotein1 are central antagonistic regulators of bone mineralization. Proceedings of the National Academy of Sciences, USA, 99: 94459449.

25. Anderson HC, Hsu HHT, Morris DC et al. (1997). Matrix vesicles in osteomalacic hypophosphatasia bone contain apatite-like mineral crystals. American Journal of Pathology, 151: 1555-1561.

26. Anderson HC, Sipe JB, Hessle L et al. (2004). Impaired calcification around matrix vesicles of growth plate and bone in alkaline phosphatase-deficient mice. American Journal of Pathology, 164: 841847.

27. Leone FA, Degreve L \& Baranauskas JA (1992). Sigraf: A versatile computer-program for fitting enzyme kinetic data. Biochemical Education, 20: 94-96.

28. Reddi AH \& Anderson WA (1976). Collagenous bone matrix-induced endochondral ossification and hemopoiesis. Journal of Cell Biology, 69: 557-572.

29. Urist MR, Mikulski A \& Lietze A (1979). Solubilized and insolubilized bone morphogenetic protein. Proceedings of the National Academy of Sciences, USA, 76: 1828-1832.

30. Hsu HHT \& Anderson HC (1978). Calcification of isolated matrix vesicles and reconstituted vesicles from fetal bovine cartilage. Proceedings of the National Academy of Sciences, USA, 75: 38053808.

31. Sela J, Gross UM, Kohavi D et al. (2000). Primary mineralization at the surfaces of implants. Critical Reviews in Oral Biology and Medicine, 11: 423-436.

32. Hsu HHT \& Anderson HC (1996). Evidence of the presence of a specific ATPase responsible for ATP-initiated calcification by matrix vesicles isolated from cartilage and bone. Journal of Biological Chemistry, 271: 26383-26388.

33. Pizauro JM, Demenis MA, Ciancaglini P et al. (1998). Kinetic characterization of a membrane-specific ATPase from rat osseous plate and its possible significance on endochondral ossification. Biochimica et Biophysica Acta, 1368: 108-114.

34. Demenis MA \& Leone FA (2000). Kinetic characteristics of ATP hydrolysis by a detergent-solubilized alkaline phosphatase from rat osseous plate. IUBMB Life, 49: 113-119.

35. Johnson KA, Wennberg C, Hessle L et al. (2000). Osteoblast tissuenonspecific alkaline phosphatase antagonizes and regulates PC-1. American Journal of Physiology, 279: R1365-R1377.

36. Mauro S, Manes T, Hessle L et al. (2002). Kinetic characterization of 
hypophosphatasia mutations with physiological substrates. Journal of Bone and Mineral Research, 17: 1383-1391.

37. Demenis MA, Furriel RP \& Leone FA (2003). Characterization of an ectonucleoside triphosphate diphosphohydrolase 1 activity in alkaline phosphatase-depleted rat osseous plate membranes: possible functional involvement in the calcification process. Biochimica et Biophysica Acta, 1646: 216-225.

38. Henthorn PS \& Whyte MP (1992). Missense mutations of the tissuenonspecific alkaline phosphatase gene in hypophosphatasia. Clini- cal Chemistry, 38: 2501-2505.

39. Zurutuza L, Muller F, Gibrat JF et al. (1999). Correlations of genotype and phenotype in hypophosphatasia. Human Molecular Genetics, 8: 1039-1046.

40. Harmey D, Hessle L, Narisawa S et al. (2004). Concerted regulation of inorganic pyrophosphate and osteopontin by Akp2, Enpp1 and Ank. An integrated model of the pathogenesis of mineralization disorders. American Journal of Pathology, 164: 1199-1209. 


\title{
Membrane-bound alkaline phosphatase from ectopic mineralization and rat bone marrow cell culture
}

\author{
Ana Maria S. Simão a, Márcio M. Beloti ${ }^{\text {, }}$, Rodrigo M. Cezarino ${ }^{\text {a }}$, Adalberto Luiz Rosa ${ }^{\text {b }}$, \\ João M. Pizauro ${ }^{c}$, Pietro Ciancaglini ${ }^{\text {a,* }}$ \\ ${ }^{a}$ Faculdade de Filosofia Ciências e Letras de Ribeirão Preto-FFCLRP-USP, Departamento de Química, 14040-901, Ribeirão Preto, SP, Brazil

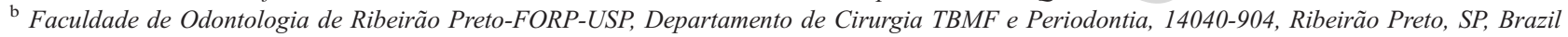 \\ ${ }^{\mathrm{c}}$ Faculdade de Ciências Agrárias e Veterinárias de Jaboticabal-FCAVJ-UNESP, Departamento de Tecnologia, 14884-900 Jaboticabal, SP, Brazil
}

Received 19 January 2006; received in revised form 9 May 2006; accepted 11 May 2006

Available online 20 May 2006

\begin{abstract}
Cells from rat bone marrow exhibit the proliferation-differentiation sequence of osteoblasts, form mineralized extracellular matrix in vitro and release alkaline phosphatase into the medium. Membrane-bound alkaline phosphatase was obtained by method that is easy to reproduce, simpler and fast when compared with the method used to obtain the enzyme from rat osseous plate. The membrane-bound alkaline phosphatase from cultures of rat bone marrow cells has a $\mathrm{MW}_{\mathrm{r}}$ of about $120 \mathrm{kDa}$ and specific PNPP activity of $1200 \mathrm{U} / \mathrm{mg}$. The ecto-enzyme is anchored to the plasma membrane by the GPI anchor and can be released by PIPLC (selective treatment) or polidocanol $(0.2 \mathrm{mg} / \mathrm{mL} \mathrm{protein} \mathrm{and} 1 \%(\mathrm{w} / \mathrm{v})$ detergent). The apparent optimum pH for PNPP hydrolysis by the enzyme was pH 10. This fraction hydrolyzes ATP (240 U/mg), ADP (350 U/ $\mathrm{mg})$, glucose 1-phosphate $(1100 \mathrm{U} / \mathrm{mg})$, glucose 6-phosphate $(340 \mathrm{U} / \mathrm{mg})$, fructose 6-phosphate $(460 \mathrm{U} / \mathrm{mg})$, pyrophosphate $(330 \mathrm{U} / \mathrm{mg})$ and $\beta$ glycerophosphate $(600 \mathrm{U} / \mathrm{mg})$. Cooperative effects were observed for the hydrolysis of PPi and $\beta$-glycerophosphate. PNPPase activity was inhibited by $0.1 \mathrm{mM}$ vanadate (46\%), $0.1 \mathrm{mM} \mathrm{ZnCl}_{2}(68 \%), 1 \mathrm{mM}$ levamisole (66\%), $1 \mathrm{mM}$ arsenate (44\%), $10 \mathrm{mM}$ phosphate $(21 \%)$ and $1 \mathrm{mM}$ theophylline (72\%). We report the biochemical characterization of membrane-bound alkaline phosphatase obtained from rat bone marrow cells cultures, using a method that is simple, rapid and easy to reproduce. Its properties are compared with those of rat osseous plate enzyme and revealed that the alkaline phosphatase obtained has some kinetics and structural behaviors with higher levels of enzymatic activity, facilitating the comprehension of the mineralization process and its function.
\end{abstract}

(C) 2006 Elsevier Inc. All rights reserved.

Keywords: Alkaline phosphatase; Bone marrow; Osseous plate; Cell culture; Glycosyl phosphatidylinositol anchor (GPI); Membrane solubilization; Kinetic data; Inhibition

\section{Introduction}

Bone marrow cells can be isolated, cultivated and induced to differentiate into cells involved in the calcification process, such as chondrocytes or osteoblasts (Phinney, 2002; Prockop et al.,

\footnotetext{
This paper is part of a special issue of CBP dedicated to "The Face of Latin American Comparative Biochemistry and Physiology" organized by Marcelo Hermes-Lima (Brazil) and co-edited by Carlos Navas (Brazil), Rene Beleboni (Brazil), Tania Zenteno-Savín (Mexico) and the editors of CBP. This issue is in honour of Cicero Lima and the late Peter W. Hochachka, teacher, friend and devoted supporter of Latin American science.

* Corresponding author. Fax: +55 166338151.

E-mail address: pietro@ffclrp.usp.br (P. Ciancaglini).
}

2003; Osyczka and Leboy, 2005). Several studies have shown that the stages of differentiation to achieve the osteoblastic phenotype require the coordinated expression of many molecules (Cheng et al., 1996; Osyczka and Leboy, 2005). Among the expression of biomolecules (collagen type I, osteopontin, bone sialoprotein and osteocalcin), high levels of tissue non-specific ecto-alkaline phosphatase, are also induced and produced during the osteoblast differentiation for the mineralization process (Cheng et al., 1996; Osyczka and Leboy, 2005). In spite of the intensive study on the ability of bone marrow cells to exhibit the proliferationdifferentiation sequence into osteoblasts, form mineralized extracellular matrix in vitro and produce alkaline phosphatase, it remains to be clarified whether the properties of this ecto-enzyme 
remain unaffected compared with those of the enzyme that participate in endochondral calcification.

Ectopic bone formation can be experimentally induced by the implantation of allogenic demineralized diaphyseal bone matrix in the subcutaneous tissue (Reddi and Huggins, 1972; Curti et al., 1986).

Studies of mineralizing tissues have revealed that the initial events of calcification occur in the matrix vesicles (MVs) that are strategically located in the mineralizing matrix. MVs are highly enriched in alkaline phosphatase, specially tissue-nonspecific alkaline phosphatase (TNAP), adenosine-5'-triphosphatase (ATPase), adenosine-5'-monophosphatase (AMPase), inorganic pyrophosphatase (PPiase) and other membrane associated enzymes (named nucleoside triphosphatase pyrophosphohydrolase, also called NTPPase, NPP1 or PC1) (Anderson, 1995; Hsu and Anderson, 1995, 1996; Anderson et al., 2004, 2005; Ciancaglini et al., 2006; Millán, 2006).

Alkaline phosphatase (E.C. 3.1.3.1) from cartilage and bone is a phosphatidylinositol-anchored membrane ectoprotein (Matsuzawa and Anderson, 1971; Pizauro et al., 1995; Millán, 2006) in contact with extracellular cartilage fluid, in which natural putative substrates are present at nanomolar or micromolar concentrations. The phosphatidylinositol structure is a phosphatidylinositol-glycolipid anchor that is covalently attached to the carboxyl terminus (C-terminus) of the protein through an amide linkage. This anchor structure of alkaline phosphatase results in lateral mobility in the membrane and allows the release of the protein from the membrane through the action of phospholipases (Harrison et al., 1995; Pizauro et al., 1995; Leone et al., 1997; Millán, 2006). The functional significance of this structural feature in mineral formation remains obscure.

The role of alkaline phosphatase in endochondral ossification remains elusive, due to difficulties in the protein extraction from cartilaginous or bone tissues and its subsequent purification (Anderson, 1995, 2003; Hsu and Anderson, 1995; Leone et al., 1997; Demenis and Leone, 2000). Some authors have reported the use of collagenase (Radisson et al., 1996) and/or organic solvents treatments (Angrand et al., 1997; Morandat et al., 2002) to obtain different forms of alkaline phosphatase derived from different tissues. These techniques used to extract and solubilize proteins from the membrane usually destroy the native membrane structure and care must be taken during the extraction/solubilization procedure to preserve the membraneassociated function of the protein.

In this work, we report an improved technique to obtain membrane-bound alkaline phosphatase from cultures of rat bone marrow cells without the use of organic solvents, collagenase or another protease treatment. The biochemical characterization of this membrane fraction is also described and the data were compared with those obtained for the membranebound enzyme from rat osseous plate, and other preparations using different fonts and methods.

\section{Materials and methods}

All aqueous solutions were made using Millipore DirectQ ultra pure apyrogenic water. Bovine serum albumin (BSA),
Tris hydroxymethyl-amino-methane (Tris), 2-amino-2-methylpropan-1-ol (AMPOL), trichloroacetic acid (TCA), adenosine 5 '-triphosphate disodium salt (ATP), sodium dodecylsulfate (SDS), p-nitrophenyl phosphate disodium salt (PNPP), dexamethazone, glucose 1-phosphate, glucose 6-phosphate, fructose 6-phosphate, $\beta$-glycerophosphate, polyoxyethylene-9lauryl ether (polidocanol), $\alpha$-naphthyl phosphate, Fast Blue RR, imidazole, levamisole, theophylline and sodium orthovanadate were from Sigma-Aldrich Chemical Co. (St Louis, MO, USA); pyrophosphate (PPi), sodium chloride and magnesium chloride were from Merck (São Paulo, SP, Brazil). $75 \mathrm{~cm}^{2}$ plastic culture flasks were from Corning (Cambridge, MA, USA). $\alpha$-MEM, fetal bovine serum, ascorbic acid, gentamicin and fungizone were from Gibco-Life Technologies (Grand Island, NY, USA). Phosphatidylinositol-specific phospholipase C (PIPLC) from Bacillus thuringiensis was obtained from Oxford University (UK). Analytical grade reagents were used without further purification.

\subsection{Rat bone marrow cell isolation and culture}

Cells were prepared and cultured according to Maniatopoulos et al. (1988). Bone marrow was obtained from young adult male rats of the Wistar strain weighing 110-120 g. The femora were excised aseptically, cleaned of soft tissues, and washed 3 times, $15 \mathrm{~min}$ each in culture medium containing 10 times the usual concentration of antibiotics (see below). The epiphyses of femora were cut off and the marrow flushed out with $20 \mathrm{~mL}$ of culture medium. Bone marrow cells released were collected in a $75 \mathrm{~cm}^{2}$ plastic culture flask containing $10 \mathrm{~mL}$ of culture medium composed by $\alpha$-MEM, supplemented with $15 \%$ fetal bovine serum, $50 \mu \mathrm{g} / \mathrm{mL}$ gentamicin, $0.3 \mu \mathrm{g} / \mathrm{mL}$ fungizone, $10^{-7} \mathrm{M}$ dexamethazone, $5 \mu \mathrm{g} / \mathrm{mL}$ ascorbic acid and $2.16 \mathrm{mg} / \mathrm{mL} \beta$-glycerophosphate. Cells were cultured for 7,14 and 21 days at $37{ }^{\circ} \mathrm{C}$ in a humidified atmosphere of $5 \% \mathrm{CO}_{2}$ and $95 \%$ air, and the medium was changed every $48 \mathrm{~h}$. The cultures were observed and evaluated under an inverted phase microscope after $24 \mathrm{~h}$, 4 days, 10 days and 14 days. When necessary, the attached cells were fixed in $10 \%$ formalin for $2 \mathrm{~h}$ at room temperature and rinsed once in PBS. After fixation, the specimens were dehydrated through a graded series of alcohol and processed for staining with $2 \%$ Alizarin red $\mathrm{S}$, that stains areas rich in calcium.

\subsection{Preparation of membrane alkaline phosphatase}

Membrane-bound alkaline phosphatase, an osteoblast-specific marker, was prepared from cell culture. The cells were washed with $50 \mathrm{mM}$ Tris- $\mathrm{HCl}$ buffer, $\mathrm{pH} 7.5$, containing $2 \mathrm{mM}$ $\mathrm{MgCl}_{2}$, removed with a spatula and resuspended in $50 \mathrm{mM}$ Tris- $\mathrm{HCl}$ buffer, $\mathrm{pH} 7.5$, containing $10 \mathrm{mM} \mathrm{MgSO}_{4}$ and $0.8 \mathrm{M}$ $\mathrm{NaCl}$ (osmotic buffer).

The cell suspension was homogenized using a "potter system" for gentle cell disruption, at $4{ }^{\circ} \mathrm{C}$ for $15 \mathrm{~min}$, centrifuged at $1000 \times \mathrm{g}$ for $3 \mathrm{~min}$ and finally the supernatant was centrifuged at $100,000 \times g$ for $1 \mathrm{~h}$ at $4{ }^{\circ} \mathrm{C}$. The pellet 
corresponding to membrane bound alkaline phosphatase, was resuspended in $50 \mathrm{mM}$ Tris- $\mathrm{HCl}$ buffer, $\mathrm{pH} 7.5$, containing $2 \mathrm{mM} \mathrm{MgCl}_{2}$, frozen in liquid nitrogen and stored at $-20^{\circ} \mathrm{C}$.

\subsection{Solubilization and partial purification of alkaline phos- phatase with polyoxyethylene 9-lauryl ether}

Membrane bound alkaline phosphatase $(0.2 \mathrm{mg} / \mathrm{mL}$ of total protein) was solubilized with $1 \%$ polidocanol $(\mathrm{w} / \mathrm{v})$ (final concentration) for $2 \mathrm{~h}$ with constant stirring at $2{ }^{\circ} \mathrm{C}$. After centrifugation at $160,000 \times \mathrm{g}$ for $1 \mathrm{~h}$ at $4{ }^{\circ} \mathrm{C}$, the solubilized enzyme was concentrated as described by Ciancaglini et al. (1990).

\subsection{Preparation of enzymatically-released alkaline phosphatase}

Membrane-bound alkaline phosphatase $(2 \mathrm{mg} / \mathrm{mL}$ of total protein) was incubated in $50 \mathrm{mM}$ Tris- $\mathrm{HCl}$ buffer, $\mathrm{pH} 7.25$ with PIPLC (0.1 U of specific phosphatidylinositol phospholipase $\mathrm{C}$ from $B$. thuringiensis) for $1 \mathrm{~h}$ under constant rotary shaking at $37{ }^{\circ} \mathrm{C}$. The incubation mixture was centrifuged at $100,000 \times g$ for $1 \mathrm{~h}$, at $4{ }^{\circ} \mathrm{C}$. The supernatant was the source of enzymatically released alkaline phosphatase and concentrated as previously described (Pizauro et al., 1995; Camolezi et al., 1999).

\subsection{Enzymatic activity measurements}

$p$-Nitrophenylphosphatase (PNPPase) activity was assayed discontinuously at $37{ }^{\circ} \mathrm{C}$ in a Spectronic (Genesys 2) spectrophotometer by following the liberation of $p$-nitrophenolate ion $\left(1 \mathrm{M}, \mathrm{pH} 13=17,600 \mathrm{M}^{-1} \mathrm{~cm}^{-1}\right)$ at $410 \mathrm{~nm}$. Standard conditions were $50 \mathrm{mM}$ AMPOL buffer, $\mathrm{pH}$ 10.0, containing $2 \mathrm{mM} \mathrm{MgCl}_{2}$ and $10 \mathrm{mM}$ PNPP in a final volume of $1.0 \mathrm{~mL}$ as previously described (Camolezi et al., 2002).

For adenosine-5'-triphosphatase (ATPase) in $\mathrm{pH} 10.0$, pyrophosphatase (PPiase) in $\mathrm{pH} \mathrm{9.0,} \mathrm{or} \mathrm{other} \mathrm{substrates} \mathrm{(ADP,}$ glucose 1-phosphate, glucose 6-phosphate, fructose 6-phosphate and $\beta$-glycerophosphate) in $\mathrm{pH} 10.0$, the activities were assayed discontinuously by measuring the amount of inorganic phosphate liberated, according to the procedure previously described (Pizauro et al., 1995), adjusting the assay medium to a final volume of $1.0 \mathrm{~mL}$. The reaction was initiated by the addition of the enzyme and stopped with $0.5 \mathrm{~mL}$ of cold $30 \%$ TCA at appropriate time intervals. The reaction mixture was centrifuged at $4000 \times \mathrm{g}$ prior to phosphate determination. Standard assay conditions were $50 \mathrm{mM}$ AMPOL buffer, containing $2 \mathrm{mM} \mathrm{MgCl}_{2}$ and substrate.

All determinations were carried out in duplicate and the initial velocities were constant for at least 90 min provided that less than $5 \%$ of substrate was hydrolyzed. Controls without added enzyme were included in each experiment to allow for the non-enzymatic hydrolysis of substrate. One enzyme unit $(1 \mathrm{U})$ is defined as the amount of enzyme hydrolyzing $1.0 \mathrm{nmol}$ of substrate per min at $37^{\circ} \mathrm{C}$ per $\mathrm{mL}$ or $\mathrm{mg}$ of protein.

\subsection{Estimation of protein}

Protein concentrations were estimated according to Hartree (1972) in the presence of $2 \%(\mathrm{w} / \mathrm{v})$ SDS. Bovine serum albumin was used as standard.

\subsection{Sucrose density gradient centrifugation}

Membrane-bound alkaline phosphatase was layered onto a continuous sucrose density gradient $(5-50 \%(\mathrm{w} / \mathrm{v})$, in $50 \mathrm{mM}$

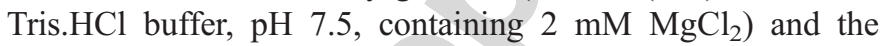
centrifugation was carried out for $4 \mathrm{~h}$ at $180,000 \times \mathrm{g}$ using a Hitachi vertical rotor (P65VT3), at $4{ }^{\circ} \mathrm{C}$. Fractions of $0.5 \mathrm{~mL}$ were collected and assayed for protein concentration, PNPPase activity and refractive index.

\subsection{Denaturating polyacrylamide gel electrophoresis}

The molecular mass of alkaline phosphatase was estimated by SDS-PAGE (7 or $10 \%$ ) with $5 \%$ stacking gel, according to Laemmli (1970), using silver nitrate for protein staining. Myosin (205 kDa), $\beta$-galactosidase (116 kDa), phosphorylase b $(97 \mathrm{kDa})$, bovine serum albumin $(66 \mathrm{kDa})$, egg albumin (45 kDa) and carbonic anhydrase $(29 \mathrm{kDa})$ were used as molecular markers. Protein samples were concentrated using Microcon 30 (Amicon). Phosphohydrolytic activity on the gel was detected in $50 \mathrm{mM}$ AMPOL buffer, $\mathrm{pH} 10.0$, containing $2 \mathrm{mM} \mathrm{MgCl}_{2}, 0.12 \%(\mathrm{w} / \mathrm{v}) \alpha$-naphthyl phosphate and $0.12 \%$ $(\mathrm{w} / \mathrm{v})$ Fast Blue $\mathrm{RR}$, at $37{ }^{\circ} \mathrm{C}$, previously renaturated with $50 \mathrm{mM}$ Tris- $\mathrm{HCl}$ buffer, $\mathrm{pH}$ 7.5.

\section{9. $p H$ sensitivity of catalysis}

The effect of $\mathrm{pH}$ on PNPPase activity of membrane-bound alkaline phosphatase was measured in $50 \mathrm{mM}$ buffer over the $\mathrm{pH}$ range of 6.5 to 10.5 . Imidazole buffer was used in the 6.5 to 7.5 range, Tris in the 7.0 to 9.0 range and AMPOL in the 8.5 to 10.5 range. The $\mathrm{pH}$ of the reaction mixture was measured both before and after the assay and did not vary by more than 0.05 units. PNPPase activity was assayed as described above.

\subsection{Effect of inhibitors on PNPPase activity}

PNPPase activity of membrane-bound alkaline phosphatase was determined in the presence of different inhibitors: vanadate, $\mathrm{ZnCl}_{2}$, levamisole, arsenate, phosphate and theophylline. Inhibitor solutions were prepared previously in reaction medium buffer and the PNPPase activity was assayed as described earlier.

\subsection{Determination of kinetic parameters}

Kinetic data from substrate hydrolysis were calculated using the software described by Leone et al. (2005). $V_{\mathrm{M}}, K_{0.5}$ and $n$, which are reported as computed values, stand for maximal velocity, apparent dissociation constant (or Michaelis-Menten constant), and Hill coefficient, respectively. 


\section{Results}

Rat bone marrow cells were grown for different periods of time. In Fig. 1, it can be observed that after 14 days of growth, cultures presented osteoblast-like cells and mineralizing matrix, with maximum values of PNPPase activity and protein concentration around $1200 \mathrm{U} / \mathrm{mg}$ and $0.6 \mathrm{mg} / \mathrm{mL}$, respectively (Fig. 2).

As shown in Fig. 3, only a single peak with phosphohydrolytic activity was found in the gradient, around 20-25\% sucrose, indicating that this preparation was relatively homogeneous, without soluble protein contaminant present in the crude homogenate.

The apparent optimum $\mathrm{pH}$ for PNPP hydrolysis by membrane-bound alkaline phosphatase varied with substrate concentration, becoming more acidic at lower concentrations (data not shown). However, in the presence of $10 \mathrm{mM}$ substrate and $2 \mathrm{mM} \mathrm{MgCl}_{2}$, an optimum $\mathrm{pH}$ of 10 was determined (Fig. 4).

The hydrolysis of several substrates by the membrane-bound alkaline phosphatase is shown in Table 1, together with data obtained for the enzyme from osseous plate. This fraction showed a broad substrate specificity, in the same way as observed for the enzyme from osseous plate, hydrolyzing different substrates in $\mathrm{pH}$ 10. PNPP (1200 U/mg) and glucose 1phosphate $(1100 \mathrm{U} / \mathrm{mg})$ presented higher values of velocity of hydrolysis, and other substrates were hydrolyzed to a minor extent.

Some kinetic characteristics of membrane-bound alkaline phosphatase were also evaluated and Table 2 summarizes the data obtained for the hydrolysis of different substrates, together with data reported for the enzyme from induced bone. These data reveal that cooperative effects were observed for PPi and $\beta$-glycerophosphate for the enzyme from cell culture, and both enzymes presented similar $K_{0.5}$ values.

PNPPase activity of membrane-bound alkaline phosphatase was also studied in the presence of several characteristic inhibitors for alkaline phosphatase (Table 3) and compared with the enzyme from induced bone. As can be observed, more efficient inhibition of PNPPase activity was obtained with levamisole, $\mathrm{ZnCl}_{2}$ and theophylline and moderate effect was obtained with phosphate, arsenate and vanadate.

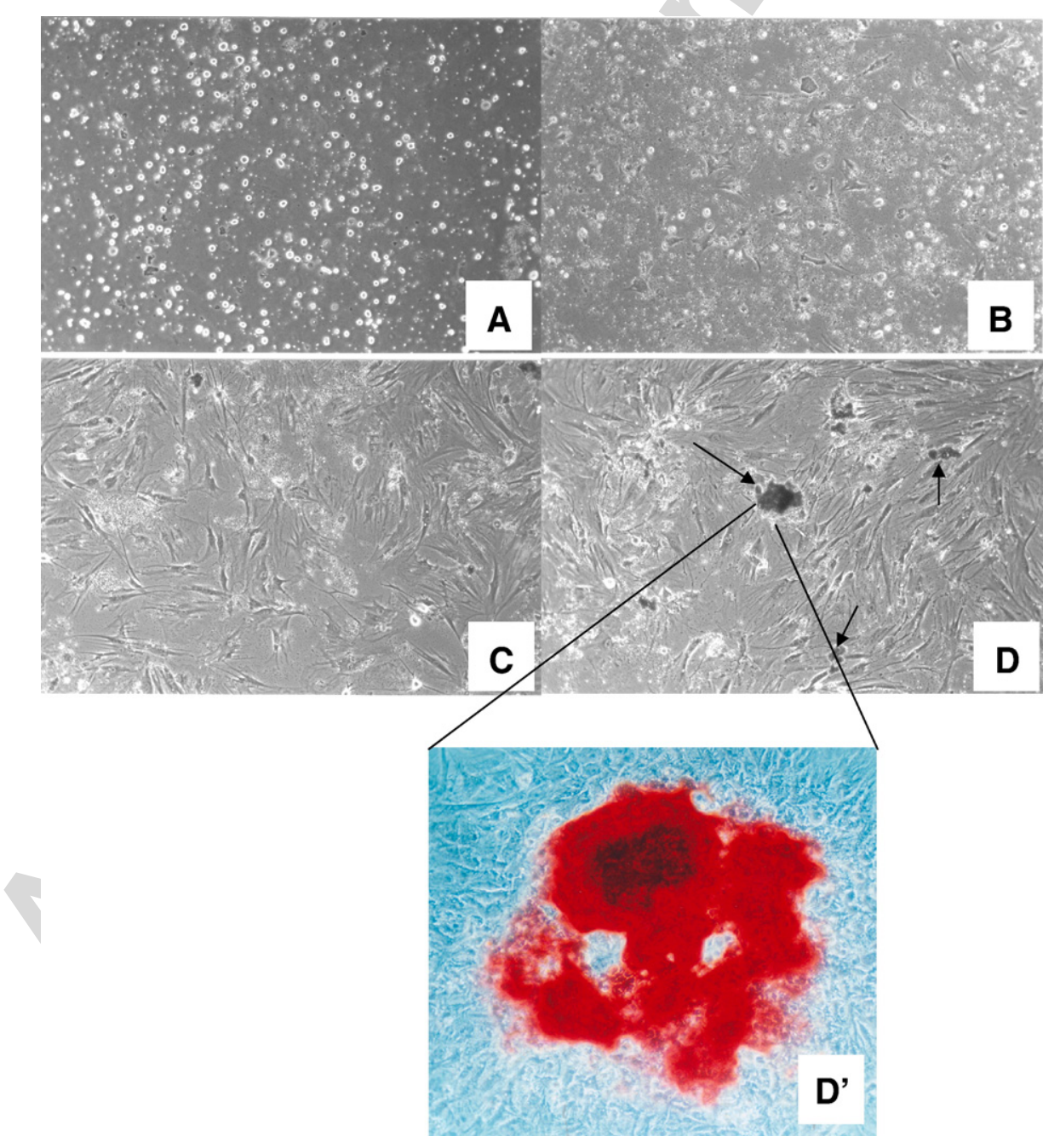

Fig. 1. Culture of osteoblasts after: (A) 24 h; (B) 4 days; (C) 10 days; (D) 14 days and (D') Alizarin red S stained. The cells were grown in culture medium composed by $\alpha$-MEM, supplemented with $15 \%$ fetal bovine serum, $50 \mu \mathrm{g} / \mathrm{mL}$ gentamicin, $0.3 \mu \mathrm{g} / \mathrm{mL}$ fungizone, $10^{-7} \mathrm{M}$ dexametazone, $5 \mu \mathrm{g} / \mathrm{mL}$ ascorbic acid and $2.16 \mathrm{mg} / \mathrm{mL} \beta-$ glycerophosphate, as described in Section 2.1. Original magnification $10 \times(\rightarrow$ indicate mineral matrix). 


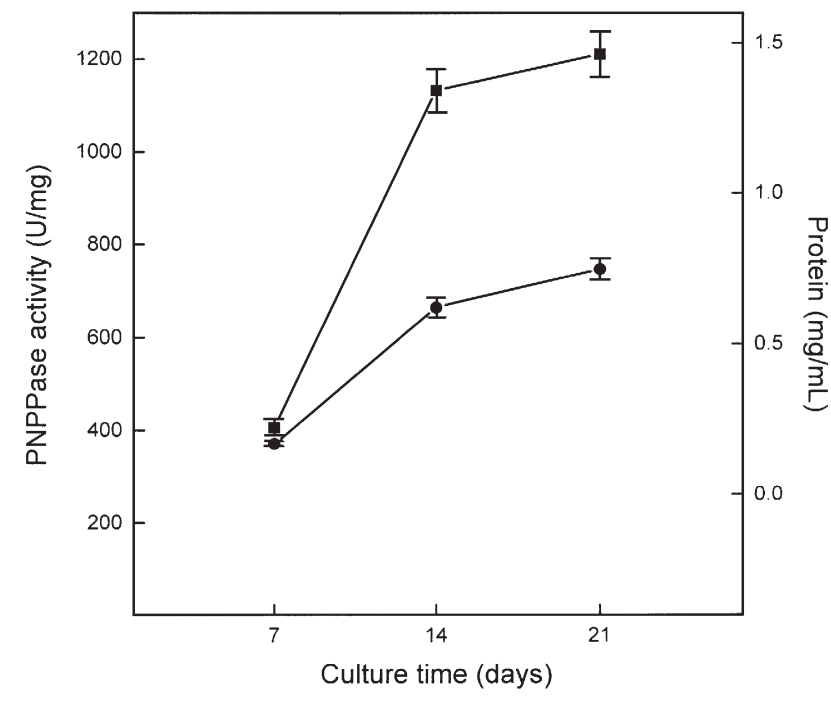

Fig. 2. Effect of growth time of osteoblastic culture on PNPPase activity and protein concentration of alkaline phosphatase membrane fraction. The cells were grown in culture medium composed by $\alpha$-MEM, supplemented with $15 \%$ fetal bovine serum, $50 \mu \mathrm{g} / \mathrm{mL}$ gentamicin, $0.3 \mu \mathrm{g} / \mathrm{mL}$ fungizone, $10^{-7} \mathrm{M}$ dexametazone, $5 \mu \mathrm{g} / \mathrm{mL}$ ascorbic acid and $2.16 \mathrm{mg} / \mathrm{mL} \beta$-glycerophosphate. The culture was stopped after 7, 14 and 21 days and the cells were processed as described in Section 2.2. Membrane-bound alkaline phosphatase was assayed for PNPPase activity ( $\square$ ) and protein concentration ( $)$. The PNPPase activity was assayed discontinuously at $37^{\circ} \mathrm{C}$, as described in Section 2.5. Data reported as the mean \pm S.D. of triplicate measurement of different enzyme preparations.

SDS-PAGE of membrane-bound alkaline phosphatase revealed diffuse protein bands after silver staining (lane 2), but, by assaying phosphomonohydrolase activity (lane 3 ), only a single distinct band was observed with $\mathrm{MW}_{\mathrm{r}}$ of about $120 \mathrm{kDa}$ (Fig. 5A). When this band was extracted and incubated with $\beta$ mercaptoethanol and electrophoresed in SDS-PAGE, it revealed a $\mathrm{MW}_{\mathrm{r}}$ of about $60 \mathrm{kDa}$, but the phosphomonohydrolase activity was abolished (results not shown).

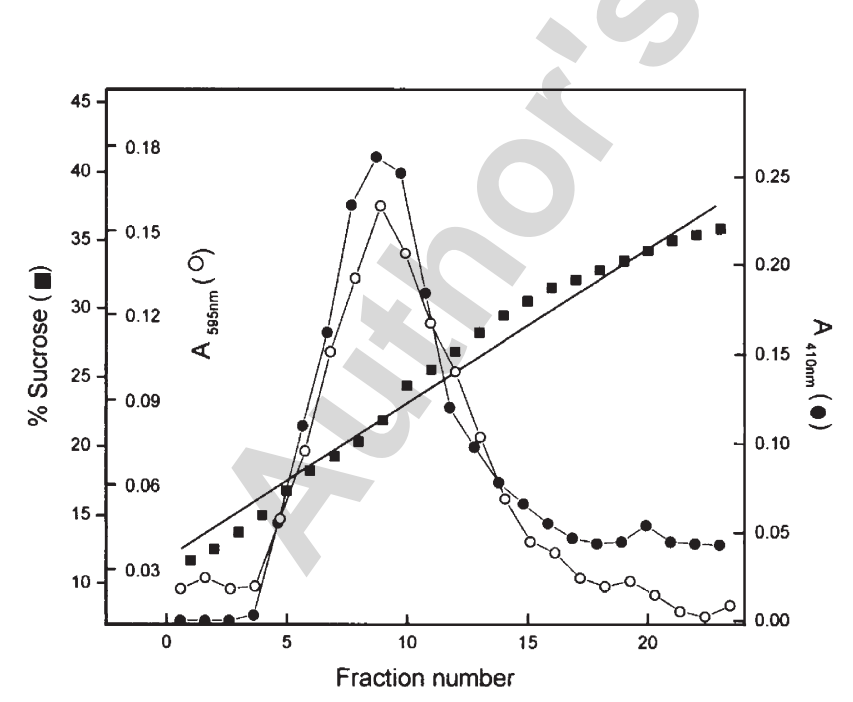

Fig. 3. Sucrose density gradient centrifugation of membrane-bound alkaline phosphatase from rat bone marrow cell culture. $0.5 \mathrm{~mL}$ aliquots were collected using a peristaltic pump and were assayed for protein concentration, PNPPase activity and refractive index. This figure is representative of three independent experiments of different enzyme preparations.

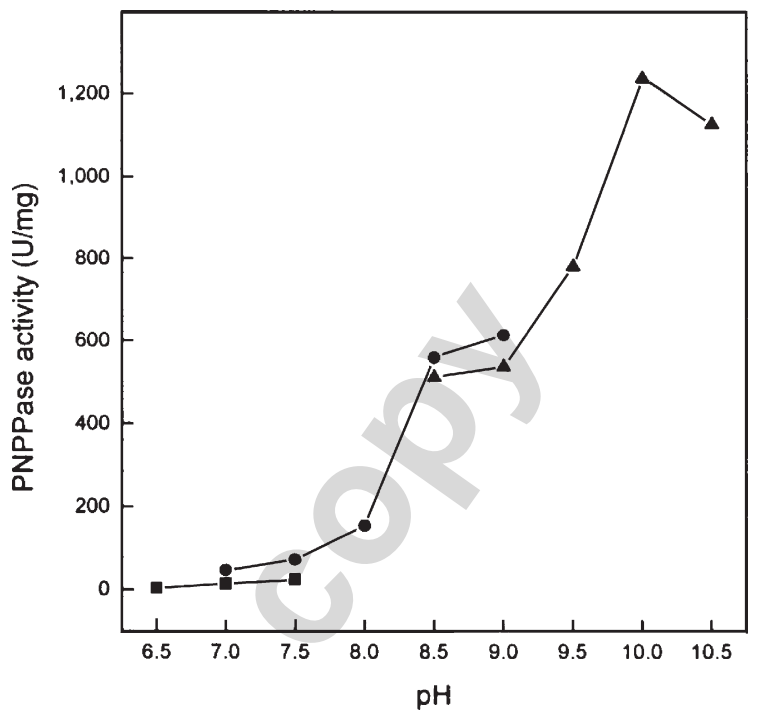

Fig. 4. Effect of $\mathrm{pH}$ on PNPP hydrolysis by alkaline phosphatase membrane fraction. The membrane was obtained after 14 days of osteoblastic culture. PNPPase activity was assayed in reactional medium containing $10 \mathrm{mM}$ PNPP and $2 \mathrm{mM} \mathrm{MgCl}$, buffered with $50 \mathrm{mM}$ of: (ם) imidazole ( $\mathrm{pH} 6.5-7.5)$; ( Tris- $\mathrm{HCl}(\mathrm{pH} 7.0-9.0)$ and (\) AMPOL ( $\mathrm{pH}$ 8.5-10.5). The PNPPase activity was assayed discontinuously at $37{ }^{\circ} \mathrm{C}$, as described in Section 2.5. This figure is representative of three independent experiments of different enzyme preparations.

The effect of different agents on the solubilization of alkaline phosphatase obtained from cell cultures and osseous plate is show in Table 4. It can be observed that the treatment of membrane fraction from cell culture with phospholipase $\mathrm{C}$ released about $92 \%$ of alkaline phosphatase activity, while the amount of solubilized enzyme was about $63 \%$ when polidocanol was used.

SDS-PAGE of the solubilized membrane fractions previously incubated with both phospholipase and polidocanol revealed a relatively large number of protein bands when stained with

Table 1

Comparative values for the phosphomonohydrolase activity of membranebound alkaline phosphatases

\begin{tabular}{|c|c|c|c|c|}
\hline \multirow[t]{2}{*}{ Substrate } & \multicolumn{2}{|l|}{ Bone marrow } & \multicolumn{2}{|c|}{ Induced bone } \\
\hline & $\begin{array}{l}\text { Activity } \\
\text { (U/mg) }\end{array}$ & $\begin{array}{l}\text { Activity } \\
(\%)\end{array}$ & $\begin{array}{l}\text { Activity } \\
\text { (U/mg) }\end{array}$ & $\begin{array}{l}\text { Activity } \\
(\%)\end{array}$ \\
\hline PNPP & $1317.4 \pm 19.4$ & 100.0 & $498.0^{(a)}$ & $100.0^{(\mathrm{a})}$ \\
\hline ADP & $352.2 \pm 9.3$ & 26.7 & n.d. & n.d. \\
\hline ATP & $240.2 \pm 7.5$ & 18.3 & $411.2^{(\mathrm{a})}$ & $83.1^{\text {(a) }}$ \\
\hline Glucose 1-phosphate & $1094.6 \pm 18.1$ & 83.1 & $192.6^{(a)}$ & $38.1^{(\mathrm{a})}$ \\
\hline Glucose 6-phosphate & $339.7 \pm 8.6$ & 25.8 & $455.1^{(a)}$ & $91.0^{(\mathrm{a})}$ \\
\hline Fructose 6-phosphate & $465.2 \pm 9.7$ & 35.3 & n.d. & n.d. \\
\hline$\beta$-Glycerophosphate & $654.3 \pm 13.8$ & 49.7 & $453.3^{(a)}$ & $91.0^{(\mathrm{a})}$ \\
\hline Pyrophosphate & $330.4 \pm 8.5$ & 25.0 & $102.0^{(\mathrm{b})}$ & $20.5^{(b)}$ \\
\hline
\end{tabular}

The membrane was obtained after 14 days of osteoblastic culture or after 14 days of the implants of demineralized bone (Pizauro et al., $1987^{(\mathrm{a})}$ and Ciancaglini et al., $\left.1990^{(\mathrm{b})}\right)$.

n.d. = not determined.

The activity of the membrane fraction of osteoblastic culture was determined in $50 \mathrm{mM}$ AMPOL buffer, $\mathrm{pH} 10.0$, containing $2 \mathrm{mM} \mathrm{MgCl}_{2}$ and $10 \mathrm{mM}$ substrate, at $37{ }^{\circ} \mathrm{C}$, as described in Section 2.5. Data reported as the mean \pm S.D. of triplicate measurements of different enzyme preparations. 
Table 2

Kinetic parameters for the hydrolysis of different substrates by membrane-bound alkaline phosphatase

\begin{tabular}{|c|c|c|c|c|c|c|}
\hline \multirow[t]{2}{*}{ Substrate } & \multicolumn{3}{|c|}{ Bone marrow } & \multicolumn{3}{|l|}{ Induced bone } \\
\hline & $K_{0.5}(\mathrm{mM})$ & $V_{\mathrm{M}}(\mathrm{U} / \mathrm{mg})$ & $n$ & $\mathrm{~K}_{0.5}(\mathrm{mM})$ & $V_{\mathrm{M}}(\mathrm{U} / \mathrm{mg})$ & $n$ \\
\hline PNPP & $0.16 \pm 0.02$ & $1201.7 \pm 12.3$ & 0.9 & $0.10 \pm 0.01^{(a)}$ & $498.0 \pm 2.51^{(\mathrm{a})}$ & $0.9^{\text {(a) }}$ \\
\hline$\beta$-Glycerophosphate & $0.42 \pm 0.11$ & $590.6 \pm 17.7$ & 0.6 & $1.23 \pm 0.12^{(\mathrm{a})}$ & $453.3 \pm 12.3^{(\mathrm{a})}$ & $0.9^{(\mathrm{a})}$ \\
\hline ATP & $1.47 \pm 0.04$ & $240.8 \pm 7.22$ & 1.0 & $1.43 \pm 0.20^{(\mathrm{a})}$ & $411.2 \pm 15.4^{(\mathrm{a})}$ & $0.5^{(\mathrm{a})}$ \\
\hline PPi & $2.69 \pm 0.08$ & $365.5 \pm 11.0$ & 1.3 & $1.40 \pm 0.09^{(\mathrm{b})}$ & $102.0 \pm 10.6^{(\mathrm{b})}$ & $2.2^{(\mathrm{b})}$ \\
\hline
\end{tabular}

The membrane was obtained after 14 days of osteoblastic culture or after 14 days of the implants of demineralized bone (Pizauro et al., $1987^{(\mathrm{a})}$ and Ciancaglini et al., $\left.1990^{(\mathrm{b})}\right)$.

The activity of the membrane fraction of osteoblastic culture was determined in $50 \mathrm{mM} \mathrm{AMPOL}$ buffer, $\mathrm{pH} 10.0$, containing $2 \mathrm{mM} \mathrm{MgCl} \mathrm{m}_{2}$ and substrate, at $37{ }^{\circ} \mathrm{C}$, as described in Section 2.5. Data reported as the mean \pm S.D. of triplicate measurements of different enzyme preparations.

silver nitrate (not shown), but only a single protein band when stained for phosphomonohydrolase activity (lanes 2 and 3), with $\mathrm{MW}_{\mathrm{r}}$ of about $120 \mathrm{kDa}$ (Fig. 5B).

\section{Discussion}

The physiological role of alkaline phosphatase in calcification is still to be clarified, due to the method of preparation of the enzyme from osseous or cartilaginous tissue and its solubilization, which can alter its structure, catalytic activity and properties related to its function. In fact, activities 10-fold lower have been reported for membrane-bound alkaline phosphatase obtained by treatment of human osteoblastic culture with collagenase (Radisson et al., 1996), and for the enzyme extracted from bovine intestinal solubilized with organic solvents (Angrand et al., 1997), when compared with the activity obtained for the membrane-bound enzyme from bone marrow cell culture.

Thus, one of the benefits of this method is that a simple homogenization and resuspension procedure is enough to obtain the membrane-bound alkaline phosphatase derived from osteoblastic cultures, avoiding the utilization of proteases and/or organic solvent treatment, which contributes to a less denaturing effect on the enzyme. Another important feature of

Table 3

Effect of several inhibitors on the phosphohydrolytic activity of membranebound alkaline phosphatase

\begin{tabular}{llcc}
\hline Inhibitors & Concentration & \multicolumn{2}{c}{ PNPPase activity $(\%)$} \\
\cline { 3 - 4 } & & Bone marrow & Induced bone \\
\hline Control & - & $100.0 \pm 3.9$ & $100.0^{(\mathrm{c})}$ \\
Vanadate & $100 \mu \mathrm{M}$ & $53.8 \pm 2.5$ & $43.9^{(\mathrm{c})}$ \\
$\mathrm{ZnCl}_{2}$ & $100 \mu \mathrm{M}$ & $31.9 \pm 0.3$ & $61.0^{(\mathrm{c})}$ \\
Levamisole & $100 \mu \mathrm{M}$ & $34.4 \pm 1.4$ & $22.1^{(\mathrm{c})}$ \\
Arsenate & $1 \mathrm{mM}$ & $56.0 \pm 2.1$ & $24.6^{(\mathrm{c})}$ \\
Phosphate & $10 \mathrm{mM}$ & $78.8 \pm 4.2$ & $52.3^{(\mathrm{c})}$ \\
Theophylline & $1 \mathrm{mM}$ & $28.2 \pm 1.5$ & $7.7^{(\mathrm{c})}$
\end{tabular}

Comparative values of inhibition of the membrane fraction obtained after 14 days of osteoblastic culture or after 14 days of the implants of demineralized bone (Curti et al., $1987^{(\mathrm{c})}$ ).

The activity of the membrane fraction of osteoblastic culture was determined in $50 \mathrm{mM}$ AMPOL buffer, $\mathrm{pH} 10.0$, containing $2 \mathrm{mM} \mathrm{MgCl}_{2}$ and $10 \mathrm{mM}$ PNPP, at $37{ }^{\circ} \mathrm{C}$, as described in Section 2.5, and $100 \%$ corresponds to $1200 \mathrm{U} / \mathrm{mg}$ of initial activity. Data reported as the mean \pm S.D. of triplicate measurements of different enzyme preparations. this technique is the facility to carry out in vitro tests to simulate in vivo situations that may normally occur during the mineralization process.

This study demonstrates that, under inverted phase microscopy, rat bone marrow cells are differentiated into osteoblastlike cells and mineralizating matrix in the medium (Fig. 1). These cells also have high levels of PNPPase activity and of protein concentration after 14 days of osteoblastic culture (Fig. 2 ). Contradictory results have been found for the pattern of expression of alkaline phosphatase by osteoblasts cultured from human marrow cells, fetal rat calvaria and fetal bovine long bones (Owen et al., 1990; Stein et al., 1990; Ibaraki et al., 1992; Cheng et al., 1996; Millán, 2006). Our results are in agreement with those reported by Curti et al. (1986) showing that the inducement of the mineralization process by demineralized matrix reaches maximum values 14 days after the implantation of the demineralized bone matrix. If it is a coincidence or a necessary time for the cells to reach a maximum growth remains unclear. Moreover, our preparation also shows an increase of almost three times in the values of PNPPase activity in
A

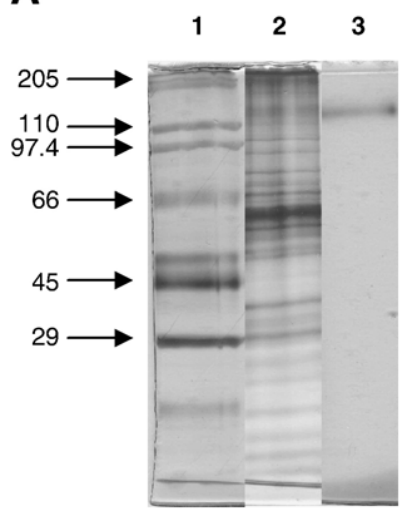

B

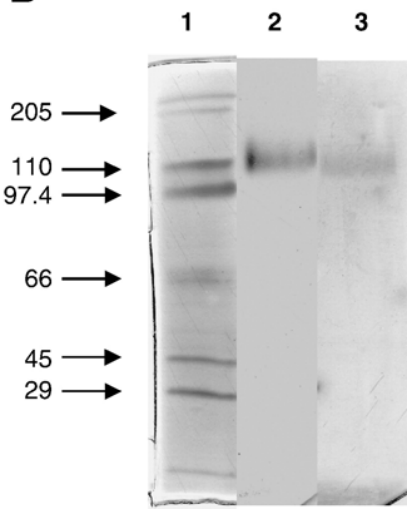

Fig. 5. Polyacrylamide gel electrophoresis of membrane-bound alkaline phosphatase done according to Laemmli (1970), renaturated with $50 \mathrm{mM}$ Tris- $\mathrm{HCl}$ buffer, $\mathrm{pH} 7.5$, and stained using silver nitrate or phosphomonohydrolytic activity. (A) Electrophoresis was carried out in 10\% gels; (Lane 1) molecular mass standards; (lane 2) proteins present in alkaline phosphatase membrane fractions; (Lane 3) phosphohydrolytic activity of alkaline phosphatase membrane fractions. (B) Electrophoresis was carried out in 7\% gels: (Lane 1) molecular mass standards; (Lane 2) phosphohydrolytic activity of alkaline phosphatase solubilized with PIPLC; (Lane 3) phosphohydrolytic activity of alkaline phosphatase solubilized with polidocanol. 
Table 4

Effect of different treatments on the solubilization of alkaline phosphatase

\begin{tabular}{lllcc}
\hline $\begin{array}{l}\text { Membrane } \\
\text { samples }\end{array}$ & \multirow{2}{*}{ Treatment } & & \multicolumn{2}{c}{ PNPPase activity } \\
\cline { 3 - 5 } & & & \multicolumn{1}{c}{$(\mathrm{U} / \mathrm{mL})$} & $(\%)$ \\
\hline Bone marrow & \multirow{2}{*}{ PIPLC } & Not solubilized & $102.9 \pm 1.1$ & 9.0 \\
& & Solubilized & $1050.5 \pm 4.2$ & 92.5 \\
& \multirow{2}{*}{ Polidocanol } & Not solubilized & $78.0 \pm 1.3$ & 5.4 \\
& & Solubilized & $911.0 \pm 3.1$ & 63.4 \\
Induced bone & \multirow{2}{*}{ PIPLC } & Not solubilized & $48.4^{(\mathrm{d})}$ & $6.5^{(\mathrm{d})}$ \\
& & Solubilized & $792.7^{(\mathrm{d})}$ & $106.5^{(\mathrm{d})}$ \\
& \multirow{2}{*}{ Polidocanol } & Not solubilized & $11.2^{(\mathrm{b})}$ & $1.5^{(\mathrm{b})}$ \\
& & Solubilized & $900.6^{(\mathrm{d})}$ & $121.1^{(\mathrm{d})}$ \\
\hline
\end{tabular}

Comparative values of the solubilization of the membrane-bound alkaline phosphatase was obtained after 14 days of osteoblastic culture or after 14 days of the implants of demineralized bone (Pizauro et al., $1995^{(\mathrm{d})}$ and Ciancaglini et al., $\left.1990^{(\mathrm{b})}\right)$.

Membranes were incubated with each agent and processed as described in Sections 2.3 and 2.4. The activity of the membrane fraction of osteoblastic culture was determined in $50 \mathrm{mM}$ AMPOL buffer, $\mathrm{pH}$ 10.0, containing $2 \mathrm{mM}$ $\mathrm{MgCl}_{2}$ and $10 \mathrm{mM} \mathrm{PNPP}$, at $37{ }^{\circ} \mathrm{C}$, as described in Section 2.5, and $100 \%$ corresponds to $1200 \mathrm{U} / \mathrm{mL}$ of initial activity. Data reported as the mean \pm S.D. of triplicate measurements of different enzyme preparations.

comparison to those obtained by the induced mineralization process (Table 1). In contrast, maximum expression of alkaline phosphatase for human osteoblastic cells cultures was obtained only after 3 weeks (Ferrera et al., 2002).

To investigate if the membrane fraction was really rich in alkaline phosphatase, a set of experiments was performed with the objective of characterizing this membrane fraction.

The single peak detected along the sucrose gradient (Fig. 3) suggests that the preparation is sufficiently homogeneous to be used in kinetic studies. The position of the alkaline phosphatase activity peak in a region of the gradient corresponding to 20$25 \%$ sucrose suggests the presence of a high molecular weight complex, typical of membrane fractions. A similar result was found for the enzyme obtained from rat bone matrix-induced cartilage (Curti et al., 1986).

It is known that alkaline phosphatase obtained from osseous tissues is a multifunctional enzyme, capable of hydrolyzing in alkaline $\mathrm{pH}$ phosphate monoesters, pyrophosphate, phosphodiesters, and also of catalyzing transphosphorylation reactions (Pizauro et al., 1987, 1992; Ciancaglini et al., 1990, 1997, 2006; Rezende et al., 1994, 1998; Leone et al., 1997; Demenis and Leone, 2000; Millán, 2006).

Thus, our enzymological studies regarding the specificity of the membrane-bound alkaline phosphatase has demonstrated its ability to hydrolyze several substrates. It is evident from these results (Table 1) that this membrane fraction contains an enzyme that functions as a nonspecific phosphomonohydrolase, and the broad substrate specificity observed seems common to alkaline phosphatases from different sources (Pizauro et al., 1987; Say et al., 1996; Leone et al., 1997; Hamade et al., 2003). Taking into account the values reported for the membrane-bound enzyme from osseous plate, membrane fraction from osteoblastic culture had a higher ability to hydrolyse glucose 1-phosphate and $\beta$-glycerophosphate, since these activities represented $83 \%$ and $49 \%$, respectively, when compared with that observed for PNPP (Table 1). Another significant difference was that this membrane fraction hydrolysed ATP (18\%), ADP (26\%), fructose 6-phosphate (35\%) and glucose 6-phosphate (25\%) slowly, in contrast with the relatively fast hydrolysis rates of these substrates by the soluble alkaline phosphatase from rat osseous plate (Say et al., 1991). The effect of concentration of different substrates on the activity of membrane-bound alkaline phosphatase obtained from cell cultures and from osseous plate is shown in Table 2. $K_{0.5}$ values obtained for the hydrolysis of different substrates by the enzyme from osteoblastic culture are of the same magnitude as those reported for alkaline phosphatase from induced bone (Pizauro et al., 1987; Ciancaglini et al., 1990, 2006). Together, these results demonstrate significant differences between the membrane-bound alkaline phosphatase from osteoblastic culture, the soluble alkaline phosphatase purified from osseous plate (Say et al., 1991) and the membrane-bound enzyme from osseous plate (Pizauro et al., 1987; Ciancaglini et al., 2006).

The membrane fraction was inhibited by some classical alkaline phosphatase inhibitors. The behavior for PNPPase activity of the enzyme (Table 3) was similar to that described for alkaline phosphatase from induced bone (Curti et al., 1987). The satisfactory inhibition of PNPPase activity obtained by these inhibitors, mainly levamisole and theophylline, strongly suggests that this membrane fraction is rich in alkaline phosphatase, since these compounds are specific for phosphatases.

Alkaline phosphatase is a membrane-bound enzyme attached to the cell membrane via a glycosylphosphatidylinositol anchor (GPI) that can be extracted from the membrane using different reagents. Treatment of membrane-bound alkaline phosphatase with PIPLC results in a soluble form of the enzyme without the 1-2 diacylglycerol moieties. The $\mathrm{C}$-terminus in this preparation retains one glycan and one inositol-phosphate group. This method was standardized by Pizauro et al. (1995). The treatment of membrane-bound alkaline phosphatase from osteoblastic culture with phospholipase C released about $90 \%$ of alkaline phosphatase activity (Table 4), while the enzyme obtained from osseous plate was released more efficiently from the membrane by the same treatment (Pizauro et al., 1994, 1995; Leone et al., 1997).

Detergent treatment yields an enzyme with the GPI anchor structure intact. The method using polidocanol is based on the methodology described by Ciancaglini et al. (1990) and others who used it (Camolezi et al., 2002; Ierardi et al., 2002). The amount of solubilized enzyme activity was maximum, about $60 \%$, when polidocanol was used at a final concentration of $1 \%$ $(\mathrm{w} / \mathrm{v})$ (Table 4). Under these conditions, the PNPPase activity of the solubilized alkaline phosphatase was in the range of $900 \mathrm{U} /$ $\mathrm{mL}$, which is similar to the activity of the polidocanolsolubilized alkaline phosphatase for the enzyme obtained from osseous plate, as reported by Ciancaglini et al. (1990).

The apparent optimum $\mathrm{pH}$ for PNPP hydrolysis by alkaline phosphatase was 10.0 (Fig. 4) and similar to that reported for alkaline phosphatases obtained from different sources (Freemont, 1993; Millán, 2006). The apparent optimum pH dropping with decreasing substrate concentration is in agreement with data reported for soluble (Say et al., 1991), phosphatidylinositol- 
specific phospholipase C-solubilized (Pizauro et al., 1995), detergent-solubilized (Pizauro et al., 1988) and membranebound alkaline phosphatase (Rezende et al., 1993).

SDS-PAGE revealed that this membrane fraction also presents a single protein band when stained for phosphomonohydrolase activity, with $\mathrm{MW}_{\mathrm{r}}$ of about $120 \mathrm{kDa}$ (Fig. 5A), similar to that reported for native alkaline phosphatase from osseous plate (Pizauro et al., 1987; Ciancaglini et al., 1990; Leone et al., 1997). However, this value was somewhat smaller in comparison with that reported for osteoblastic alkaline phosphatase from human bone cell cultures (Radisson et al., 1996).

When stained for phosphomonohydrolase activity, the activity of solubilized enzyme with both PIPLC and polidocanol also showed just a single band on SDS-PAGE with $\mathrm{MW}_{\mathrm{r}}$ of about $120 \mathrm{kDa}$ (Fig. 5B), suggesting that this enzyme is a homodimer constituted of two apparently identical subunits of $M_{r} 60 \mathrm{kDa}$ as described by several authors for the enzyme from induced bone (Ciancaglini et al., 1990; Pizauro et al., 1995; Leone et al., 1997). These results prove that both solubilization procedures do not modify the structural and kinetic properties of the enzyme of rat bone marrow cells.

Other enzymes also can be found in these membrane fractions such as NPP1 (or PC-1, NPP) and PHOSPHO1. NPP1 is also an integral protein with $130 \mathrm{kDa}$, with an optimum $\mathrm{pH}$ around 7.4-8.8 and does not respond to classical inhibitors of alkaline phosphatases. Also, PHOSPHO1, with a molecular mass around $32 \mathrm{kDa}$, has optimum $\mathrm{pH}$ around 6.7 (Anderson et al., 2004; Roberts et al., 2004). Considering that $\mathrm{pH} 10$ was used to monitor the PNPPase activity of membrane-bound alkaline phosphatase, we are excluding the possibility of the phosphomonohydrolase activity to be attributed to the enzymes described above.

The data presented here describe a protein with molecular mass of $120 \mathrm{kDa}$, with high levels of PNPPase activity inhibited by classical inhibitors of alkaline phosphatases. The enzyme has optimum $\mathrm{pH}$ and kinetic properties comparable to the enzyme obtained from induced bone and can be solubilized efficiently with both PIPLC and polidocanol. We believe that the method described here is simple, rapid and suitable to obtain membranebound alkaline phosphatase from cultures of rat bone marrow cells. Also, with modifications in the homogenization procedures and kinetic buffers, this method could be used to study other enzymes involved in the mineralization process. Finally, it is important to emphasize the advantage of the considerable reduction in the time needed to obtain this membrane fraction in comparison with the method used to obtain the membranebound enzyme from osseous plate, which contributes to a smaller denaturing effect on the enzyme, facilitating the comprehension of the mineralization process and the role of alkaline phosphatase during this process.

\section{Acknowledgements}

The authors thank Priscila Cerviglieri for revision of the text. We also thank FAPESP and CNPq for the financial support given to our laboratory. AMSS received a FAPESP scholarship.

\section{References}

Anderson, H.C., 1995. Molecular biology of matrix vesicles. Clin. Orthop. Rel Res. 314, 266-280.

Anderson, H.C., 2003. Matrix vesicles and calcification. Curr. Rheumatol. Rep. 5, 222-226.

Anderson, H.C., Sipe, J.B., Hessle, L., Dhamyamraju, R., Atti, E., Camacho, N.P., Millán, J.L., 2004. Impaired calcification around matrix vesicles of growth plate and bone in alkaline phosphatase-deficient mice. Am. J. Pathol. $164,841-847$.

Anderson, H.C., Garimella, R., Tague, S.E., 2005. The role of matrix vesicles in growth plate development and biomineralization. Front. Biosci. 10, $822-837$.

Angrand, M., Briolay, A., Ronzon, F., Roux, B., 1997. Detergent-mediated reconstitution of a glycosyl-phosphatidylinositol-protein into liposomes. Eur. J. Biochem. 250, 168-176.

Camolezi, F.L., Pizauro, J.M., Leone, F.A., Ciancaglini, P., 1999. A simple laboratory experiment to demostrate the interaction of proteins bearing glycosyl phosphatidylinositol anchors with liposomes. J. Biochem. Educ. 27, 37-40

Camolezi, F.L., Daghastanli, K.R.P., Magalhães, P.P., Pizauro, J.M., Ciancaglini, P., 2002. Construction of an alkaline phosphatase-liposome system: a tool for biomineralization study. Int. J. Biochem. Cell Biol. 34, 1091-1101.

Cheng, S.L., Zhang, S.F., Avioli, L.V., 1996. Expression of bone matrix proteins during dexamethasone-induced mineralization of human bone marrow stromal cells. J. Cell. Biochem. 61, 182-193.

Ciancaglini, P., Pizauro, J.M., Rezende, A.A., Rezende, L.A., Leone, F.A., 1990. Solubilization of membrane-bound matrix-induced alkaline phosphatase with polyoxyetylene 9-lauryl ether (polidocanol): purification and metalloenzyme properties. Int. J. Biochem. 22, 385-392.

Ciancaglini, P., Pizauro, J.M., Leone, F.A., 1997. Dependence of divalent metal ions on phosphotransferase activity of osseous plate alkaline phosphatase. J. Inorg. Biochem. 66, 51-55.

Ciancaglini, P., Simão, A.M.S., Camolezi, F.L., Millán, J.L., Pizauro, J.M., 2006. Contribution of matrix vesicles and alkaline phosphatase to ectopic bone formation. Braz. J. Med. Biol. Res. 39, 603-610.

Curti, C., Pizauro, J.M., Rossinholi, G., Vugman, I., Mello de Oliveira, J.A., Leone, F.A., 1986. Isolation and kinetic properties of an alkaline phosphatase from rat bone matrix-induced cartilage. Cell. Mol. Biol. 32, 55-62.

Curti, C., Pizauro, J.M., Ciancaglini, P., Leone, F.A., 1987. Kinetic characteristics of some inhibitors of matrix-induced alkaline phosphatase. Cell. Mol. Biol. 33, 625-635.

Demenis, M.A., Leone, F.A., 2000. Kinetic characteristics of ATP hydrolysis by a detergent-solubilized alkaline phosphatase from rat osseous plate. IUBMB Life 49, 113-119.

Ferrera, D., Poggi, S., Biassoni, C., Dickson, G.R., Astigiano, S., Barbieri, O., Favre, A., Franzi, A.T., Strangio, A., Federici, A., Manduca, P., 2002. Threedimensional cultures of normal human osteoblasts: proliferation and differentiation potential in vitro and upon ectopic implantation in nude mice. Bone 30, 718-725.

Freemont, A.J., 1993. Basic bone cell biology. Int. J. Exp. Pathol. 74, 411-416.

Hamade, E., Azzar, G., Radisson, J., Buchet, R., Roux, B., 2003. Chick embryo anchored alkaline phosphatase and mineralization process in vitro. Eur. J. Biochem. 270, 2082-2090.

Harrison, G., Shapiro, I.M., Golub, E.E., 1995. The phosphatidylinositolglycolipid anchor on alkaline phosphatase facilitates mineralization initiation in vitro. J. Bone Miner. Res. 10, 568-573.

Hartree, E.F., 1972. Determination of protein: a modification of the Lowry method that gives a linear photometric response. Anal. Biochem. 48, $422-427$

Hsu, H.H.T., Anderson, H.C., 1995. A role for ATPase in the mechanisms of ATP-dependent $\mathrm{Ca}$ and phosphate deposition by isolated rachictic matrix vesicles. Int. J. Biochem. 27, 1349-1356.

Hsu, H.H.T., Anderson, H.C., 1996. Evidence of the presence of a specific ATPase repressible for ATP-initiated calcification by matrix vesicles isolated from cartilage and bone. J. Biol. Chem. 271, 26383-26388. 
Ibaraki, K., Termine, J.D., Whitson, S.W., Young, M.F., 1992. Bone matrix mRNA expression in differentiating fetal bovine osteoblasts. J. Bone Miner. Res. 7, 743-754.

Ierardi, D.F., Pizauro, J.M., Ciancaglini, P., 2002. Erythrocyte ghost cellalkaline phosphatase: construction and characterization of a vesicular system for use in biomineralization studies. Biochim. Biophys. Acta 1567, $183-192$.

Laemmli, U.K., 1970. Cleavage of structural proteins during the assembly of the head bacteriophage T4. Nature (Lond.) 227, 680-685.

Leone, F.A., Pizauro, J.M., Ciancaglini, P., 1997. Rat osseous plate alkaline phosphatase: a search for its role in biomineralization. Trends Comp. Biochem. Physiol. 3, 57-73.

Leone, F.A., Baranauskas, J.A., Furriel, R.P.M., Borin, I.A., 2005. SigrafW: an easy-to-use program for fitting enzyme kinetic data. Biochem. Molec. Educ. 33, 399-403.

Maniatopoulos, C., Sodek, J., Melcher, A.H., 1988. Bone formation in vitro by stromal cells obtained from bone marrow of young adult rats. Cell Tissue Res. 254, 317-330.

Matsuzawa, T., Anderson, H.C., 1971. Phosphatases of epiphyseal cartilage studied by electron microscopic cytochemical methods. J. Histochem. Cytochem. 19, 801-808.

Millán, J.L., 2006. Mammalian Alkaline Phosphatases: From Biology to Applications in Medicine and Biotechnology. Ed. WILEY-VCH Verlag $\mathrm{GmbH} \& \mathrm{Co}$. KGaA, Weinheim.

Morandat, S., Bortolato, M., Roux, B., 2002. Cholesterol-dependent insertion of glycosylphosphatidylinositol-anchored enzyme. Biochim. Biophys. Acta 1564, 473-478.

Osyczka, A.M., Leboy, P.S., 2005. Bone morphogenetic protein regulation of early osteoblast genes in human marrow stromal cells is mediated by extracellular signal-regulated kinase and phosphatidylinositol 3-kinase signaling. Endocrinology 146, 3428-3437.

Owen, T.A., Aronow, M., Shalhoub, V., Barone, L.M., Wilming, L., Tassinari, M.S., Kennedy, M.B., Pockwinse, S., Lian, J.B., Stein, G.S., 1990. Progressive development of the rat osteoblast phenotype in vitro: reciprocal relationships in expression of genes associated with osteoblast proliferation and differentiation during formation of the bone extracellular matrix. J. Cell. Physiol. 143, 420-430.

Phinney, D.G., 2002. Building a consensus regarding the nature and origin of mesenchymal stem cells. J. Cell. Biochem. Suppl. 38, 7-12.

Pizauro, J.M., Curti, C., Ciancaglini, P., Leone, F.A., 1987. Triton X-100 solubilized bone matrix-induced alkaline phosphatase. Comp. Biochem. Physiol. B 87, 921-926.
Pizauro, J.M., Curti, C., Ciancaglini, P., Leone, F.A., 1988. Kinetic properties of Triton X-100 solubilized bone matrix induced alkaline phosphatase. Cell. Mol. Biol. 34, 553-562.

Pizauro, J.M., Ciancaglini, P., Leone, F.A., 1992. Phosphotransferase activity associated with rat osseous plates alkaline phosphatase: a possible role in biomineralization. Int. J. Biochem. 24, 1391-1396.

Pizauro, J.M., Ciancaglini, P., Leone, F.A., 1994. Osseous plate alkaline phosphatase is anchored by GPI. Braz. J. Med. Biol. Res. 27, 453-456.

Pizauro, J.M., Ciancaglini, P., Leone, F.A., 1995. Characterization of the phosphatidylinositol-specific phospholipase C-released form of rat osseous plate alkaline phosphatase and its possible significance on endochondral ossification. Mol. Cell. Biochem. 152, 121-129.

Prockop, D.J., Gregory, C.A., Spees, J.L., 2003. One strategy for cell and gene therapy: harnessing the power of adult stem cells to repair tissues. Proc. Natl. Acad. Sci. U. S. A. 100, 11917-11923.

Radisson, J., Angrand, M., Chavassieux, P., Roux, B., Azzar, G., 1996. Differential solubilization of osteoblastic alkaline phosphatase from human primary bone cell cultures. Int. J. Biochem. Cell Biol. 28, 421-430.

Reddi, A.H., Huggins, C.B., 1972. Biochemical sequences in the transformation of normal fibroblasts in adolescent rats. Proc. Natl. Acad. Sci. U. S. A. 69, 1601-1605.

Rezende, A.A., Petenusci, S.O., Urbinati, E.C., Leone, F.A., 1993. Kinetic properties of osseous plate alkaline phosphatase from diabetic rats. Comp. Biochem. Physiol., A 104, 469-474.

Rezende, A.A., Pizauro, J.M., Ciancaglini, P., Leone, F.A., 1994. Phosphodiesterase activity is a novel property of alkaline phosphatase from osseous plate. Biochem. J. 301, 517-522.

Rezende, L.A., Ciancaglini, P., Pizauro, J.M., Leone, F.A., 1998. Inorganic pyrophosphate-phosphohydrolytic activity associated with rat osseous plate alkaline phosphatase. Cell. Mol. Biol. 44, 293-302.

Roberts, S.J., Stewart, A.J., Sadler, P.J., Farquharson, C., 2004. Human PHOSPHO1 exhibits high specific phosphoethanolamine and phosphocholine phosphatase activities. Biochem. J. 382, 59-65.

Say, J.C., Ciuffi, K., Furriel, R.P.M., Ciancaglini, P., Leone, F.A., 1991. Alkaline phosphatase from rat osseous plate: purification and biochemical characterization of a soluble form. Biochim. Biophys. Acta 1074, 256-262.

Say, J.C., Furriel, R.P.M., Ciancaglini, P., Jorge, J.A., Lourdes, M., Polizeli, T. M., Pizauro, J.M., Terenzi, H.F., Leone, F.A., 1996. Conidial alkaline phosphatase from Neurospora crassa. Phytochemistry 41, 71-75.

Stein, G.S., Lian, J.B., Owen, T.A., 1990. Relationship of cell growth to the regulation of tissue-specific gene expression during osteoblast differentiation. FASEB J. 13, 3111-3123. 


\title{
Culture of osteogenic cells from human alveolar bone: A useful source of alkaline phosphatase
}

\author{
Ana Maria S. Simão ${ }^{a}$, Marcio M. Beloti ${ }^{b}$, Adalberto L. Rosa ${ }^{b}$, Paulo T. de Oliveira ${ }^{b}$, \\ José Mauro Granjeiro $^{\mathrm{c}}$, João M. Pizauro ${ }^{\mathrm{d}}$, Pietro Ciancaglini ${ }^{\mathrm{a}, *}$ \\ ${ }^{a}$ Depto Química, FFCLRP, Universidade de São Paulo, Av. Bandeirantes, 3900, 14040-901, Ribeirão Preto, SP, Brazil \\ ${ }^{\mathrm{b}}$ Laboratório de Cultura de Células, FORP, Universidade de São Paulo, Av. Café s/n, 14040-904, Ribeirão Preto, SP, Brazil \\ ${ }^{\mathrm{c}}$ Depto Biologia Celular e Molecular, Universidade Federal Fluminense, UFF, Outeiro de São João Baptista, \\ s/n 24.020-150 Campus do Valonguinho, Centro/Niterói, RJ, Brazil \\ d Depto Tecnologia, FCAV, Universidade Estadual Paulista, Via Prof. Paulo Donato Castellabe, s/n 14884-900 Jaboticabal, SP, Brazil
}

Received 2 February 2007; revised 16 March 2007; accepted 12 June 2007

\begin{abstract}
The aim of this study was to obtain membrane-bound alkaline phosphatase from osteoblastic-like cells of human alveolar bone. Cells were obtained by enzymatic digestion and maintained in primary culture in osteogenic medium until subconfluence. First passage cells were cultured in the same medium and at 7, 14, and 21 days, total protein content, collagen content, and alkaline phosphatase activity were evaluated. Bonelike nodule formation was evaluated at 21 days. Cells in primary culture at day 14 were washed with Tris- $\mathrm{HCl}$ buffer, and used to extract the membrane-bound alkaline phosphatase. Cells expressed osteoblastic phenotype. The apparent optimum pH for PNPP hydrolysis by the enzyme was pH 10.0. This enzyme also hydrolyzes ATP, ADP, fructose-1-phosphate, fructose-6-phosphate, pyrophosphate and $\beta$-glycerophosphate. PNPPase activity was reduced by typical inhibitors of alkaline phosphatase. SDS-PAGE of membrane fraction showed a single band with activity of $\sim 120 \mathrm{kDa}$ that could be solubilized by phospholipase $\mathrm{C}$ or Polidocanol.
\end{abstract}

(c) 2007 International Federation for Cell Biology. Published by Elsevier Ltd. All rights reserved.

Keywords: Alkaline phosphatase; Human alveolar bone; Cell culture; Osteogenic cells; Membrane solubilization; Kinetic data

\section{Introduction}

Biological calcification is a tightly regulated process in which different types of tissues, cells, organelles and biomolecules participate in the coordination and regulation of the metabolic events involved in accumulating large amounts of calcium phosphate (Anderson, 1995; Hsu and Anderson, 1995; Leone et al., 1997; Boyan et al., 2000). Understanding the role of each membrane component, such as membrane proteins, lipids, and carbohydrates will contribute to resolving the details of the calcification process (Anderson, 1995; Hsu and Anderson, 1995, 1996; Hsu et al., 1999, 2000; Kirsch and

\footnotetext{
* Corresponding author. Tel.: +55 163602 3753; fax: +55 1636024838 E-mail address: pietro@ffclrp.usp.br (P. Ciancaglini).
}

Claassen, 2000; Kirsch et al., 2000; Millán, 2006; Ciancaglini et al., 2006; Simão et al., 2007).

Bone marrow cells can be isolated, cultivated and induced to differentiate into cells involved in the calcification process, such as chondrocytes or osteoblasts (Phinney, 2002; Prockop et al., 2003; Osyczka and Leboy, 2005). Several studies have shown that the stages of differentiation to achieve the osteoblastic phenotype require the coordinated expression of many molecules (Cheng et al., 1996; Osyczka and Leboy, 2005). Additionally to the expression of collagen type I, osteopontin, bone sialoprotein and osteocalcin, high levels of tissue nonspecific ecto-alkaline phosphatase, are also induced during the osteoblast differentiation for the mineralization process (Cheng et al., 1996; Osyczka and Leboy, 2005).

Histological and biochemical studies have shown that membrane of mineralizing cells or matrix vesicles (MV) are 


\author{
Nomenclature \\ ALP alkaline phosphatase \\ AMPOL 2-amino-2-methyl-propan-1-ol \\ ATP adenosine $5^{\prime}$-triphosphate \\ $\alpha$-MEM minimum essential medium \\ GPI glycosylphosphatidylinositol \\ MV matrix vesicles \\ PIPLC specific phosphatidylinositol phospholipase C \\ PNPP $p$-nitrophenyl phosphate \\ Polidocanol polyoxyethylene-9-lauryl ether \\ PPi pyrophosphate \\ SDS sodium dodecylsulphate \\ TCA trichloroacetic acid \\ TNAP tissue non-specific alkaline phosphatase \\ Tris tris hydroxymethyl-amino-methane
}

highly enriched in alkaline phosphatase (ALP), specially tissue non-specific alkaline phosphatase (TNAP), adenosine5'-triphosphatase (ATPase), adenosine-5'-monophosphatase (AMPase), inorganic pyrophosphatase (PPiase) and other membrane associated enzymes (named nucleoside triphosphatase pyrophosphohydrolase, also called NTPPase, NPP1 or PC1) (Anderson, 1995; Hsu and Anderson, 1995, 1996; Anderson et al., 2004, 2005; Ciancaglini et al., 2006; Millán, 2006; Simão et al., 2007).

Alkaline phosphatase (E.C.3.1.3.1) from cartilage and bone is a phosphatidylinositol-anchored membrane ectoprotein in contact with extracellular cartilage fluid, in which natural putative substrates are present at nanomolar or micromolar concentrations (Matsuzawa and Anderson, 1971; Hunter et al., 1993; Pizauro et al., 1995; Millán, 2006; Simão et al., 2007; Garimella et al., 2006). In the phosphatidylinositol structure, a phosphatidylinositol-glycolipid anchor is covalently attached to the carboxyl terminus (C-terminus) of the protein through an amide linkage. This anchor structure of ALP results in lateral mobility in the membrane and allows the release of the protein from the membrane through the action of phospholipases (Harrison et al., 1995; Pizauro et al., 1995; Leone et al., 1997; Ciancaglini et al., 2006; Millán, 2006; Simão et al., 2007).

Osteogenic cells produce high levels of TNAP during the process of differentiation and therefore can provide a good source of this enzyme (Cheng et al., 1996; Osyczka and Leboy, 2005). Osteoblasts can be obtained from the periosteum, bone marrow, and bone explants (Breitbart et al., 1998; Krupnick et al., 2002; Xiao et al., 2003). Alveolar bone is one of the most active bones in human body and, accordingly, may be a useful site for harvesting bone cells in order to obtain TNAP (Xiao et al., 2003).

ALP is a glycosylated membrane-bound enzyme that catalyses the hydrolysis of phosphomonoester bonds and may also play a physiological role in the metabolism of phosphoethanolamine, inorganic pyrophosphate, and pyridoxal $5^{\prime}$-phosphate (Whyte, 1996). Besides providing inorganic phosphate, it has been suggested that ALP play a role in the degradation of pyrophosphate, a naturally occurring inhibitor of mineralization (Whyte, 1994). ALP is though to play a primary role in mineralization and, because it is present early in osteoblast development, has been proposed to be a progression factor in osteoblast differentiation (Aubin et al., 1993).

The best evidence that ALP actually is involved in bone mineralization has resulted from the study of the human hereditary disease hypophosphatasia (Whyte, 1996). These patients have subnormal serum levels of ALP, and the main clinical feature is defective bone mineralization, manifested as rickets or osteomalacia. More recently, two mouse ALP knockout models showed that, when the gene for ALP was specifically deleted, the mice had normal bone at birth but developed defects in bone mineralization thereafter (Waymire et al., 1995; Narisawa et al., 1997). Beck et al. (1998) showed that subbasal levels of ALP activity are sufficient to support mineralization in MC3T3-E1 cells. Using the same cell lineage, it was not observed bone-like nodule formation when ALP activity was inhibited (Sugawara et al., 2002). Despite these results, it is not clear if there is a positive correlation between the level of ALP activity and the amount of matrix mineralization.

The present study addresses an improved technique to obtain membrane-bound alkaline phosphatase from cultures of human alveolar bone derived-cells without the use of organic solvents, collagenase or another protease treatment, and the biochemical characterization of this membrane fraction is also described.

\section{Materials and methods}

\subsection{Culture of osteogenic cells derived from human alveolar bone}

Human alveolar bone fragments (explants) were obtained from healthy donors, using the research protocols approved by the Committee of Ethics in Research of the University of Sao Paulo for human tissue specimens. Osteogenic cells were obtained from these explants by enzymatic digestion using collagenase type II as described by Mailhot and Borke (1998). Alveolar bone explants were transferred into a sterile centrifuge tube and collagenase type II (Gibco, Grand Island, NY, USA) was added at a concentration of $1 \mathrm{mg} / \mathrm{ml}$ to start digestion and then placed in a $37{ }^{\circ} \mathrm{C}$ water bath under constant agitation. After $30 \mathrm{~min}$ of digestion, the supernatant was extracted and transferred to another centrifuge tube containing an equal amount of culture medium. Fresh collagenase was added to the remaining explants and the digestion process was repeated six times. The supernatant fractions numbers one and two were discarded and fractions numbers three to six were then centrifuged at $200 \times g$ for $5 \mathrm{~min}$. The bone-derived cells and remaining explants were combined and cultured until subconfluence in $\alpha$-minimum essential medium, supplemented with $10 \%$ fetal bovine serum, $50 \mu \mathrm{g} / \mathrm{ml}$ vancomycin, $20 \mu \mathrm{g} / \mathrm{ml} \mathrm{de}$ ampicillin, $0.3 \mu \mathrm{g} / \mathrm{ml}$ fungizone, $10^{-7} \mathrm{M}$ dexamethasone, $5 \mu \mathrm{g} / \mathrm{ml}$ ascorbic acid, and $7 \mathrm{mM} \beta$-glycerophosphate. Such culture conditions favored the development of the osteoblast phenotype (Rosa and Beloti, 2003; Coelho and Fernandes, 2000). During the culture period, cells were incubated at $37^{\circ} \mathrm{C}$ in a humidified atmosphere of $5 \% \mathrm{CO}_{2}$ and $95 \%$ air and the medium was changed every 3 or 4 days.

\subsection{Characterization of osteogenic cells derived from human alveolar bone}

At 7, 14 and 21 days total protein content, collagen content, and alkaline phosphatase activity were evaluated. Total protein content was measured according to Lowry et al. (1951) method and expressed as $\mu \mathrm{g}$ protein $/ 10^{4}$ cells. 
Collagen content was measured according to Reddy and Enwemeka (1996) and expressed as $\mu \mathrm{g}$ collagen $/ \mu \mathrm{g}$ protein. Alkaline phosphatase activity was measured using a commercial kit (Labtest) and expressed as $\mu$ mol thymolphtalein/h/mg protein. Bone-like nodule formation was detected at 21 days by Alizarin red S, which stains areas rich in calcium, using an inverted microscope. Also, bone-like nodule formation on titanium substrate was evaluated by scanning electron microscopy/energy dispersive spectroscopy (SEM/EDS Carl Zeiss, DSM 940A, Germany). Samples were sputter coated with carbon and selected regions of interest were investigated.

\subsection{Preparation of membrane-bound alkaline phosphatase}

Membrane-bound ALP was obtained from osteogenic cells derived from human alveolar bone in primary culture at 14 days. The cells were washed with $50 \mathrm{mM}$ Tris hydroxymethyl-amino-methane (Tris- $\mathrm{HCl}$ ) buffer, $\mathrm{pH} 7.5$, containing $2 \mathrm{mmol} / 1 \mathrm{MgCl}_{2}$, removed with a spatula and resuspended in $50 \mathrm{mmol} / 1$ Tris $-\mathrm{HCl}$ buffer, $\mathrm{pH} 7.5$, containing $10 \mathrm{mmol} / 1 \mathrm{MgSO}_{4}$ and $0.8 \mathrm{~mol} / 1 \mathrm{NaCl}$ (osmotic buffer). The cells suspension was homogenized using a "potter system" for gentle cell disruption, at $4{ }^{\circ} \mathrm{C}$ for $15 \mathrm{~min}$, centrifuged at $1000 \times g$ for $3 \mathrm{~min}$ and finally the supernatant was centrifuged at $100,000 \times g$ for $1 \mathrm{~h}$ at $4{ }^{\circ} \mathrm{C}$. The pellet corresponding to membrane-bound alkaline phosphatase was resuspended in $50 \mathrm{mmol} / \mathrm{l}$ Tris- $\mathrm{HCl}$ buffer, $\mathrm{pH} 7.5$, containing $2 \mathrm{mmol} / 1 \mathrm{MgCl}_{2}$, frozen in liquid nitrogen and stored at $-20^{\circ} \mathrm{C}$.

\subsection{Enzymatic activity measurements of membrane-bound alkaline phosphatase}

$p$-Nitrophenylphosphatase (PNPPase) activity was assayed discontinuously at $37^{\circ} \mathrm{C}$ in a Spectronic (Genesys 2) spectrophotometer by following the liberation of $p$-nitrophenolate ion $\left(\varepsilon 1 \mathrm{M}, \mathrm{pH} 13=17,600 \mathrm{M}^{-1} \mathrm{~cm}^{-1}\right)$ at $410 \mathrm{~nm}$. Standard conditions were $50 \mathrm{mM}$ AMPOL buffer, $\mathrm{pH} 10.0$, containing $2 \mathrm{mM}$ $\mathrm{MgCl}_{2}$ and $10 \mathrm{mM}$ PNPP in a final volume of $1.0 \mathrm{ml}$ as previously described (Simão et al., 2007).

The enzyme activity were determined at pH 9.0 (PPiase) or at $\mathrm{pH} 10.0$ (ATP, ADP, glucose 1-phosphate, glucose 6-phosphate, fructose 6-phosphate and $\beta$-glycerophosphate) discontinuously, by measuring the amount of inorganic phosphate liberated, according to the procedure previously described (Pizauro et al., 1995), adjusting the assay medium to a final volume of $1.0 \mathrm{ml}$. The reaction was initiated by the addition of the enzyme and stopped with $0.5 \mathrm{ml}$ of cold $30 \%$ TCA at appropriate time intervals. The reaction mixture was centrifuged at $4000 \times g$ prior to phosphate determination. Standard assay conditions were $50 \mathrm{mM}$ AMPOL buffer, containing $2 \mathrm{mM} \mathrm{MgCl}_{2}$ and substrate.

All determinations were carried out in duplicate and the initial velocities were constant for at least $90 \mathrm{~min}$ provided that less than $5 \%$ of substrate was hydrolyzed. Controls without added enzyme were included in each experiment to allow the determination of non-enzymatic hydrolysis of substrate. One enzyme unit ( $1 \mathrm{U})$ is defined as the amount of enzyme hydrolyzing $1.0 \mathrm{nmol}$ of substrate per min at $37^{\circ} \mathrm{C}$ per $\mathrm{ml}$ or $\mathrm{mg}$ of protein.

\subsection{Estimation of protein}

Protein concentrations were estimated according to Hartree (1972) in the presence of $2 \%(\mathrm{w} / \mathrm{v})$ SDS. Bovine serum albumin was used as standard.

\subsection{Solubilization and partial purification of ALP with polyoxyethylene 9-lauryl ether}

Membrane-bound ALP $(0.2 \mathrm{mg} / \mathrm{ml}$ of total protein $)$ was solubilized with $1 \%$ polidocanol $(\mathrm{w} / \mathrm{v})$ (final concentration) for $1 \mathrm{~h}$ with constant stirring at $25^{\circ} \mathrm{C}$. After centrifugation at $100,000 \times g$ for $1 \mathrm{~h}$ at $4{ }^{\circ} \mathrm{C}$, the solubilized enzyme was concentrated as described by Ciancaglini et al. (2006).

\subsection{Preparation of enzymatically-released alkaline phosphatase}

Membrane-bound ALP ( $1 \mathrm{mg} / \mathrm{ml}$ of total protein) was incubated in $50 \mathrm{mM}$ Tris- $\mathrm{HCl}$ buffer, pH 7.25 with PIPLC (0.1 U of specific phosphatidylinositol phospholipase $\mathrm{C}$ from Bacillus thuringiensis) for $1 \mathrm{~h}$ under constant rotary shaking at $37^{\circ} \mathrm{C}$. The incubation mixture was centrifuged at $100,000 \times g$ for $1 \mathrm{~h}$, at $4^{\circ} \mathrm{C}$. The supernatant was the source of enzymatically released ALP and concentrated as previously described (Ciancaglini et al., 2006).

\subsection{Effect of inhibitors on PNPPase activity}

The PNPPase activity of membrane-bound ALP was determined in the presence of different inhibitors: vanadate, $\mathrm{ZnCl}_{2}$, levamisole, arsenate, phosphate and theophylline. Inhibitors solutions were prepared previously in reaction medium buffer and the PNPPase activity was assayed as described above.

\subsection{Denaturating polyacrylamide gel electrophoresis}

The molecular mass of alkaline phosphatase was estimated by SDS-PAGE (7\%) with 5\% stacking gel, according to Laemmli (1970), using silver nitrate for protein staining. Myosin $(205 \mathrm{kDa}), \beta$-galactosidase $(116 \mathrm{kDa})$, phosphorylase b $(97 \mathrm{kDa})$, bovine serum albumin $(66 \mathrm{kDa})$, egg albumin $(45 \mathrm{kDa})$ and carbonic anhydrase $(29 \mathrm{kDa})$ were used as molecular markers. Protein samples were concentrated using Microcon 30 (Amicon). For the detection of phosphohydrolytic activity on the gel, the samples were not boiled during the PAGE preparation and the activity band was revealed in $50 \mathrm{mM}$ AMPOL buffer, pH 10.0, containing $2 \mathrm{mM} \mathrm{MgCl}_{2}, 0.12 \%$ (w/v) $\alpha$-naphthyl phosphate and $0.12 \%(\mathrm{w} / \mathrm{v})$ Fast Blue RR, at $37^{\circ} \mathrm{C}$, previously renaturated with $50 \mathrm{mM}$ Tris- $\mathrm{HCl}$ buffer, $\mathrm{pH} 7.5$.

\subsection{Determination of kinetic parameters}

Kinetic data from substrate hydrolysis were calculated using the software described by Leone et al. (2005). $V_{\mathrm{M}}, K_{0.5}$ and $n$, which are reported as computed values, stand for maximal velocity, apparent dissociation constant (or Michaelis-Menten constant), and Hill coefficient, respectively.

\section{Results}

Osteoblastic cells from human alveolar bone presented synthesis activity (Fig. 1A), produced collagen (Fig. 1B) and presented alkaline phosphatase activity (Fig. 1C). Also, it was possible to observe non-mineralized extracellular matrix at day 14 (Fig. 2A) and bone-like nodule formation at day 21 (Fig. 2B). Such nodules were observed under SEM (Fig. 2C) and analysis by EDS showed that these areas were rich in calcium (Figs. 2D,G) and phosphate (Figs. 2E,G) when cells were cultured on titanium disc as substrate (Figs. 2F,G). The brighter regions in Figs. 2D-F corresponds to the elements indicated. The calcium/phosphorous molar ratio was found to be 1.25 .

The preparation with high levels of membrane-bound alkaline phosphatase was obtained using the primary culture with 14 days of growth, with values around $600 \mathrm{U} / \mathrm{mg}$ of PNPPase activity and $0.3 \mathrm{mg} / \mathrm{ml}$ of total protein. The apparent optimum $\mathrm{pH}$ for PNPP hydrolysis by membrane-bound alkaline phosphatase in the presence of $10 \mathrm{mM}$ substrate and $2 \mathrm{mM}$ $\mathrm{MgCl}_{2}$ was 10.0 (results not shown).

The hydrolysis of several substrates by the membrane-bound alkaline phosphatase is shown in Table 1. This fraction showed broad substrate specificity, hydrolyzing different substrates at alkaline $\mathrm{pH}$. PNPP (600.4 U/mg), fructose 1-phosphate (683.4 U/mg) and $\beta$-glycerophosphate $(692.4 \mathrm{U} / \mathrm{mg}$ ) presented higher values of velocity of hydrolysis, while other substrates were hydrolyzed to a minor extent, such as ATP and ADP. 


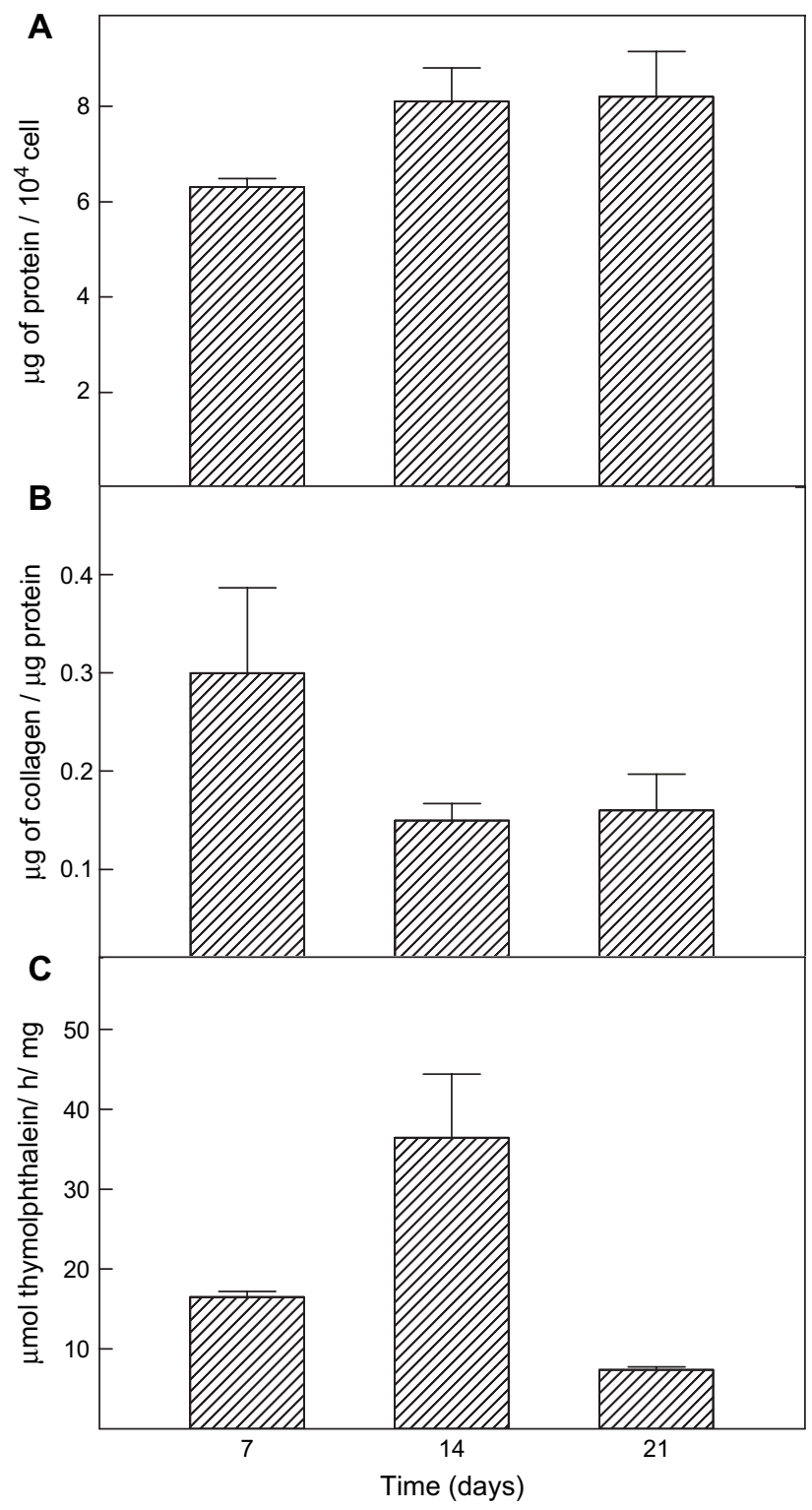

Fig. 1. (A) Total protein content; (B) collagen content; and (C) total alkaline phosphatase activity. Data are presented as mean \pm standard deviation $(n=5)$. All quantifications were done as described in Section 2.2.

Some kinetic characteristics of membrane-bound alkaline phosphatase were also evaluated for PNPP, ATP and PPi hydrolysis and a positive cooperative effect was observed for PPi (Fig. 3 and Table 2).

PNPPase activity of membrane fraction rich in alkaline phosphatase was also studied in the presence of classical inhibitors for alkaline phosphatase (Table 3). As can be observed, more efficient inhibition of PNPPase activity was obtained with levamisole (88\%) and theophylline (84\%).

SDS-PAGE of membrane-bound alkaline phosphatase revealed diffuse protein bands after silver staining (lane 2), but, by assaying phosphomonohydrolase activity (lane 3), only a single distinct band was observed with $\mathrm{MW}_{\mathrm{r}}$ of about $120 \mathrm{kDa}$ (Fig. 4A).

The effect of different agents on the solubilization of alkaline phosphatase obtained from cell cultures is shown in Table 4.
It can be observed that the treatment of membrane fraction from cell culture with phospholipase $\mathrm{C}$ released about $82 \%$ of alkaline phosphatase activity, while the amount of solubilized enzyme activity was about $227 \%$ when polidocanol was used.

SDS-PAGE of the solubilized membrane fractions previously incubated with both phospholipase or polidocanol revealed a relatively large number of protein bands when stained with silver nitrate (not shown), but only a single protein band was stained for phosphomonohydrolase activity (lanes 2 and 3), with $\mathrm{MW}_{\mathrm{r}}$ of about $120 \mathrm{kDa}$ (Fig. 4B).

\section{Discussion}

The physiological role of alkaline phosphatase in calcification is unclear in part due to the complexity of enzyme extraction process from osseous and/or cartilaginous tissue and its solubilization, which can alter its structure, catalytic activity and properties related to its function. In fact, activities 5-fold lower have been reported for membrane-bound alkaline phosphatase obtained by treatment of human osteoblastic culture with collagenase (Radisson et al., 1996), and for the enzyme from bovine intestines solubilized with organic solvents (Angrand et al., 1997), when compared with the activity obtained for the membrane-bound enzyme from bone cell culture.

Thus, the method described in the present work is worthwhile since simple homogenization and resuspension procedures were enough to obtain the membrane fraction rich in alkaline phosphatase derived from osteoblastic cultures with less denaturing effect on the enzyme due to absence of organic solvent treatment. Another important feature of this technique is the facility to carry out in vitro tests to simulate in vivo situations that normally may occur during the mineralization process.

This study demonstrates that alveolar bone derived cells could express markers compatible to osteoblastic phenotype, such as alkaline phosphatase activity and bone-like nodule formation (Figs. 1 and 2), being the PNPPase activity and protein concentration highest after 14 days of osteoblastic culture, in agreement with previous work (Curti et al., 1986; Simão et al., 2007). Corroborating this finding Beck (2003) suggests that PNPPase is an intermediate marker of osteoblastic differentiation in which the activity peak precedes the onset of matrix mineralization. On the other hand, the pattern of alkaline phosphatase activity by osteoblasts from human marrow cells, fetal rat calvaria and fetal bovine long bones showed maximum activity after three weeks in culture (Owen et al., 1990; Stein et al., 1990; Ibaraki et al., 1992; Cheng et al., 1996; Ferrera et al., 2002; Millán, 2006). In addition to distinct cell source and, consequently the use of cells in different osteoblastic differentiation stage, such discrepant findings could be attributed to culture conditions. While studies using cells in an advanced stage of differentiation from rat calvaria and trabecular bone were cultured in medium free of dexamethasone, less differentiated cells from bone marrow were cultured in medium supplemented with that. It has been well documented that bone marrow cells can be induced to differentiate into cells exhibiting osteoblast phenotype by dexamethasone, a synthetic glucocorticoid, at both concentrations $10^{-7} \mathrm{M}$ and 

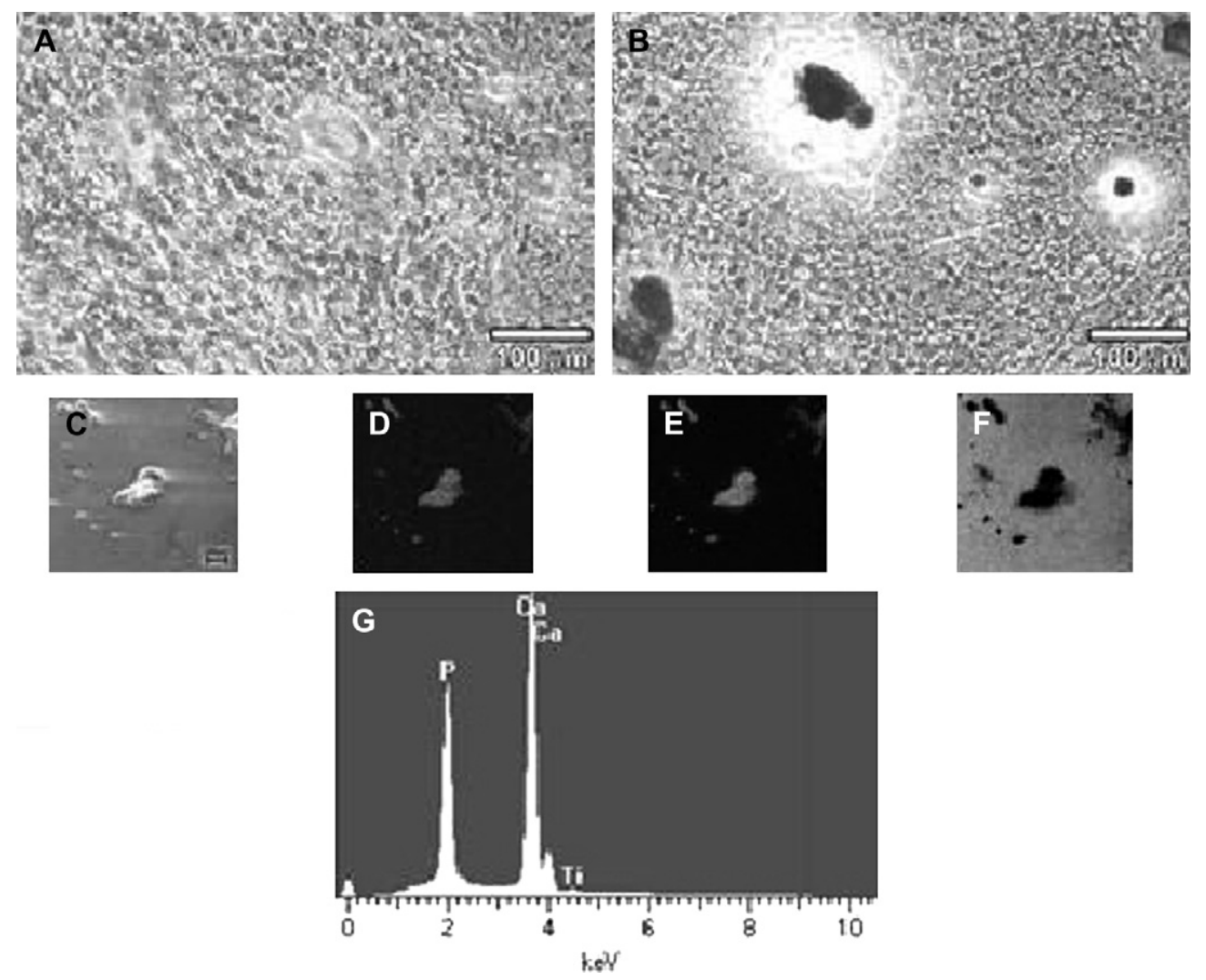

Fig. 2. Bone-like nodule formation. (A) Non-mineralized extracellular matrix at day 14. (B) Bone-like nodules at day 21. (C) Bone-like nodules observed under SEM/EDS and mapped in gray scale for (D) calcium, (E) phosphorus and (F) titanium. (G) Spectra of the components present on the surface of the titanium. SEM/ EDS technique was done as described in Section 2.2.

$10^{-8}$ M (Haynesworth et al., 1992; Scutt et al., 1996). In the present study, the process of osteoblast differentiation could be accelerated by using dexamethasone $10^{-7} \mathrm{M}$ in a culture model of more differentiated cells from alveolar bone.

To investigate the efficiency of the proposed method for alkaline phosphatase-enriched membrane fraction obtention and its kinetic properties, a set of experiments was performed. The apparent optimum $\mathrm{pH}$ for PNPP hydrolysis by alkaline phosphatase was 10.0 and similar values were reported for alkaline phosphatases obtained from different sources (Freemont, 1993; Millán, 2006).

Alkaline phosphatase obtained from osseous tissues is a multifunctional enzyme, capable of hydrolyzing in alkaline pH phosphate monoesters, pyrophosphate, phosphodiesters, and also of catalyzing transphosphorylation reactions (Pizauro

Table 1

Phosphomonohydrolase activity of membrane-bound alkaline phosphatase

\begin{tabular}{llc}
\hline Substrate $[10 \mathrm{mM}]$ & Activity $(\mathrm{U} / \mathrm{mg})$ & Activity $(\%)$ \\
\hline PNPP & 600.4 & 100.0 \\
ADP & 120.5 & 20.1 \\
ATP & 161.1 & 26.8 \\
Fructose-1-phosphate & 683.4 & 113.9 \\
Fructose-6-phosphate & 259.2 & 43.2 \\
$\beta$-glycerophosphate & 692.4 & 115.4 \\
Pyrophosphate & 270.6 & 45.1 \\
\hline
\end{tabular}

The activity was determined in $50 \mathrm{mM}$ AMPOL buffer, $\mathrm{pH} \mathrm{10.0,} \mathrm{containing}$ $2 \mathrm{mM} \mathrm{MgCl} 2$ and substrate, at $37{ }^{\circ} \mathrm{C}$, as described in Section 2. et al., 1987, 1992; Ciancaglini et al., 1990, 1997, 2006; Rezende et al., 1994, 1998; Leone et al., 1997; Demenis and Leone, 2000; Simão et al., 2007; Millán, 2006). Thus, our enzymological studies regarding the specificity of the membrane-bound alkaline phosphatase have demonstrated its ability to hydrolyze several substrates. It is evident from these results (Table 1) that this membrane fraction contains an enzyme that functions as a non-specific phosphomonohydrolase, and the broad substrate specificity observed seems common to alkaline phosphatases from different sources (Pizauro et al., 1987; Say et al., 1996; Leone et al., 1997; Hamade et al., 2003; Simão et al., 2007; Ciancaglini et al., 2006). Taking into account the values reported for the membrane-bound enzyme from osseous plate, membrane fraction from alveolar culture had a higher ability to hydrolyse $\beta$-glycerophosphate and fructose-1-phosphate (115\% and $113 \%$, respectively), when compared with that observed for PNPP (Table 1), while the hydrolysis of $\beta$-glycerophosphate by membrane-bound enzyme from osseous plate was $91 \%$ when compared with that observed for PNPP. Another significant difference was that this membrane fraction hydrolyzed fructose-6-phosphate (43\%) and ADP (20\%) slowly, in contrast with the relatively fast hydrolysis rates of these substrates by the soluble alkaline phosphatase from rat osseous plate (Say et al., 1991). Compared to the alkaline phosphatase obtained from culture of osteoblasts (Simão et al., 2007), membrane-bound enzyme from alveolar bone hydrolyses faster all the substrates tested, except 


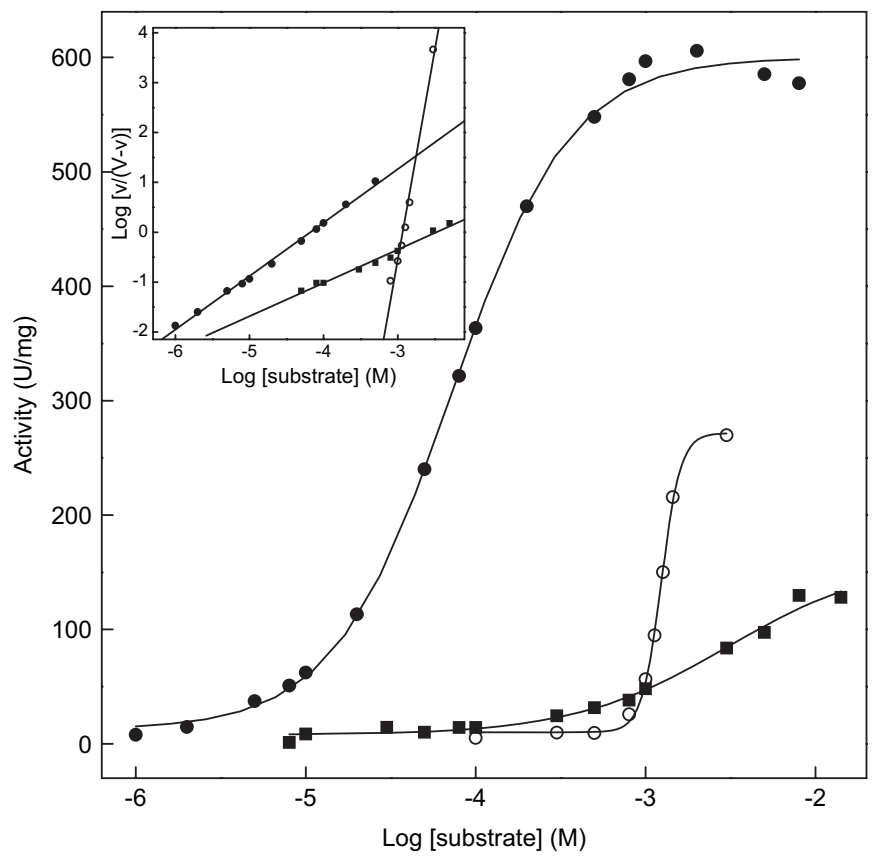

Fig. 3. Effect of increasing concentrations of different substrates in the activity of membrane-bound alkaline phosphatase from human alveolar bone cells: $(\boldsymbol{O})$ PNPP, ( $\bigcirc$ ) PPi and ( $\square$ ) ATP. Assays were determined at $37^{\circ} \mathrm{C}$ and buffered with $50 \mathrm{mM}$ AMPOL, pH 10.0 for PNPP and ATP or 9.0 for PPi, containing $2 \mathrm{mM} \mathrm{MgCl}_{2}$ and substrate. Insert: Hill plot of the interaction of the substrate with the enzyme. Each point represents the mean of triplicate measurements of different enzyme preparations, which was considered to be statistically significant at $P \leq 0.05$.

ADP, which is hydrolyzed $33 \%$ slower. Together, these results demonstrate significant differences between different enzyme preparations: membrane-bound alkaline phosphatase from osteoblastic culture (Simão et al., 2007), soluble alkaline phosphatase purified from osseous plate (Say et al., 1991) and membrane-bound enzyme from osseous plate (Pizauro et al., 1987; Ciancaglini et al., 2006).

In relation to the kinetic characteristics of the membrane fraction, the effect of concentration of different substrates on the activity of membrane-bound alkaline phosphatase obtained from cell cultures is shown in Table 2. These initial studies were performed using both ATP and PPi as substrates because they are naturally occurring substrates and they are also believed to have an important role in the biomineralization process, since PPi is a well-known inhibitor of bone mineralization and both ATP and PPi can be hydrolyzed by alkaline phosphatase and the product of this hydrolysis also regulates the activity of the enzyme (Pizauro et al., 1987; Rezende et al., 1998; Leone et al., 1997; Garimella et al., 2006; Anderson, 1995,

Table 2

Kinetic parameters for the hydrolysis of PNPP, ATP and PPi by membranebound alkaline phosphatase from human alveolar bone cells

\begin{tabular}{lllll}
\hline Substrate & $K_{0.5}(\mathrm{mM})$ & $V_{\mathrm{M}}(\mathrm{U} / \mathrm{mg})$ & $n$ & $k_{\text {cat }} / K_{0.5}\left(\mathrm{M}^{-1} \mathrm{~s}^{-1}\right)$ \\
\hline PNPP & 0.07 & 600.4 & 1.0 & $1.7 \times 10^{4}$ \\
ATP & 3.02 & 161.1 & 0.7 & $1.1 \times 10^{2}$ \\
PPi & 1.26 & 270.6 & 7.9 & $4.3 \times 10^{2}$ \\
\hline
\end{tabular}

Enzymatic activities were assayed as described in Section 2.
Table 3

Effect of several inhibitors on the phosphohydrolytic activity of membranebound alkaline phosphatase

\begin{tabular}{lcc}
\hline Inhibitors & Concentrations $(\mathrm{mM})$ & PNPPase activity $(\%)$ \\
\hline Control & - & 100.0 \\
Vanadate & 0.1 & 20.8 \\
$\mathrm{ZnCl}_{2}$ & 0.1 & 19.9 \\
Levamisole & 0.1 & 12.4 \\
Arsenate & 1.0 & 29.4 \\
Phosphate & 10.0 & 46.7 \\
Theophylline & 1.0 & 15.7 \\
\hline
\end{tabular}

The activity of the membrane fraction was determined in $50 \mathrm{mM}$ AMPOL buffer, $\mathrm{pH} 10.0$, containing $2 \mathrm{mM} \mathrm{MgCl}_{2}$ and $10 \mathrm{mM} \mathrm{PNPP}$, at $37^{\circ} \mathrm{C}$, as described in Section 2, and $100 \%$ corresponds to $600.4 \mathrm{U} / \mathrm{mg}$ of initial activity.

$2003,2004) . K_{0.5}$ values obtained for the hydrolysis of different substrates by the enzyme from alveolar bone are of the same magnitude as those reported for alkaline phosphatase from induced bone and for the enzyme from rat bone marrow cells culture (Pizauro et al., 1987; Ciancaglini et al., 1990, 2006; Simão et al., 2007). When PNPP was used as substrate (Fig. 3), membrane-bound alkaline phosphatase exhibited a "Michaelian" behavior. Similar results were described for the membranebound and polidocanol or Triton X-100 solubilized enzymes from rat osseous plate (Pizauro et al., 1987; Ciancaglini et al., 1990) and for the membrane-bound enzyme from rat bone marrow cells culture (Simão et al., 2007). For the ATPase activity, it can be observed in Fig. 3 that the kinetics parameters are similar for membrane-bound and polidocanol or Triton X100 solubilized enzymes from rat osseous plate (Pizauro et al., 1987; Ciancaglini et al., 1990) and for the membrane-bound enzyme from rat bone marrow cells culture (Simão et al., 2007), with a little difference in the affinity constant. Also, no cooperative effects were observed in opposition to that reported for membrane-bound enzyme obtained from rat osseous plate (Pizauro et al., 1987; Demenis and Leone, 2000). Finally, when PPi was used as substrate (Fig. 3), a higher positive cooperative effect than that observed for the membrane-bound enzyme obtained from cultures of rat bone marrow cells and induced bone (Ciancaglini et al., 1990; Simão et al., 2007) was found. It could also be observed that, while the enzymatic efficiency $\left(k_{\text {cat }} / K_{0.5}\right)$ remained comparable for the hydrolysis of ATP and PPi by the membrane-bound enzyme, the value of $\left(k_{\text {cat }} / K_{0.5}\right)$ increased about 100 -fold when PNPP was used as substrate. These data suggest that the catalytic efficiency of the enzyme can be strongly affected by molecules binding to it. In fact, Ciancaglini et al. (2006) recently demonstrated that the enzyme obtained from rat osseous plate may be modulated by the substrate that is hydrolyzed and presented different kinetic parameters depending on the microenvironment where the enzyme is localized (membrane-bound, PIPLCsolubilized or polidocanol-solubilized enzymes).

The membrane-bound alkaline phosphatase was inhibited by some classical inhibitors (Table 3). The kinetic behavior for PNPPase activity of the enzyme was similar to that described for alkaline phosphatases from other sources or tissues (Leone et al., 1997; Pizauro et al., 1995). The inhibition of PNPPase activity obtained by these inhibitors, mainly levamisole and 

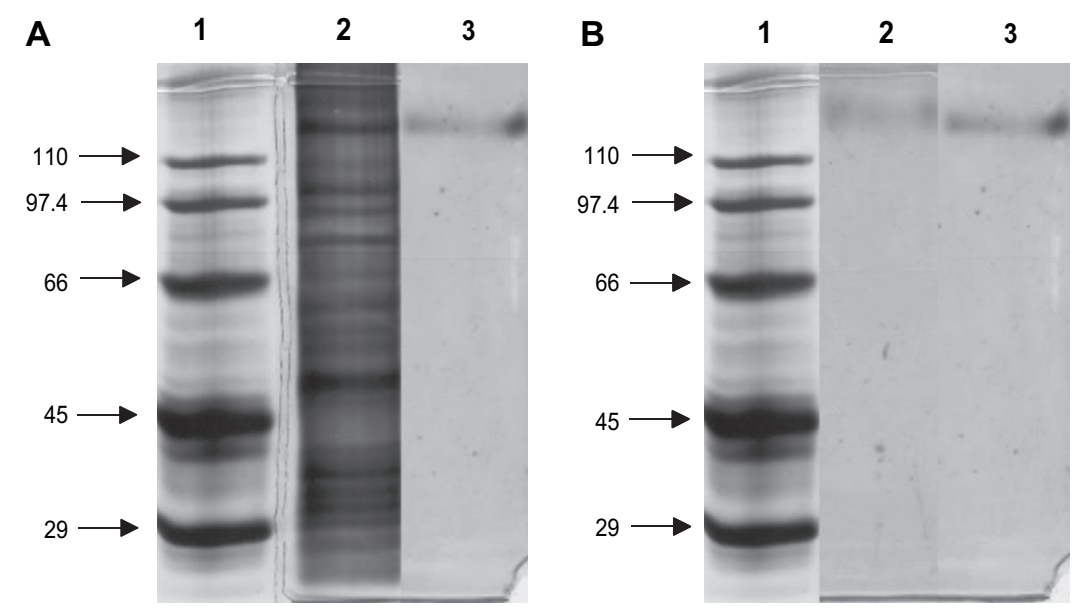

Fig. 4. Polyacrylamide gel electrophoresis of membrane-bound alkaline phosphatase done according to Laemmli (1970), renaturated with 50 mM Tris-HCl buffer, pH 7.5 and stained using silver nitrate or phosphomonohydrolytic activity. (A) Electrophoresis was carried out in 7\% gels; (Lane 1) molecular mass standards; (Lane 2) proteins present in membrane fractions rich in alkaline phosphatase; (Lane 3) phosphohydrolytic activity of membrane fractions. (B) Electrophoresis was carried out in 7\% gels: (Lane 1) molecular mass standards; (Lane 2) phosphohydrolytic activity of alkaline phosphatase solubilized with PIPLC; (Lane 3) phosphohydrolytic activity of alkaline phosphatase solubilized with polidocanol.

theophylline, strongly suggests that this membrane fraction is rich in alkaline phosphatase, since these compounds are specific for phosphatases. Excess of ATP (>10 mM) and PPi (>8 mM) also inhibited the activity of membrane fraction, but contradictory results have been found for the membrane-bound enzyme obtained from rat osseous plate (Rezende et al., 1998).

Alkaline phosphatase is a membrane-bound enzyme attached to the cell membrane via a glycosylphosphatidylinositol anchor (GPI) that can be extracted from the membrane using different reagents. Treatment of membrane-bound alkaline phosphatase with PIPLC results in a soluble form of the enzyme without the 1-2 diacylglycerol moieties. The C-terminus in this preparation retains one glycan and one inositol-phosphate group. This method was standardized by Pizauro et al. (1995). The treatment of membrane-bound alkaline phosphatase from human alveolar bone cells culture with phospholipase $\mathrm{C}$ released about $82 \%$ of alkaline phosphatase activity into the soluble environment (Table 4), while the enzyme obtained from rat osseous plate was more efficiently released from the membrane by the same treatment (Pizauro et al., 1994, 1995; Leone et al., 1997).

Detergent treatment non-specifically solubilizes all the proteins of the membrane and yields an enzyme with the intact

Table 4

Effect of different treatments on the solubilization of membrane-bound alkaline phosphatase obtained after 14 days of human alveolar bone cells culture

\begin{tabular}{llcr}
\hline Treatment & Samples & \multicolumn{2}{c}{ PNPPase activity } \\
\cline { 3 - 4 } & & $(\mathrm{U} / \mathrm{ml})$ & $(\%)$ \\
\hline PIPLC & Not solubilized & 51.5 & 28.6 \\
& Solubilized & 146.9 & 81.6 \\
Polidocanol & Not solubilized & 25.4 & 14.1 \\
& Solubilized & 409.2 & 227.2 \\
\hline
\end{tabular}

Membranes were incubated with each agent and processed as described in Section 2. The activity was determined in $50 \mathrm{mM}$ AMPOL buffer, $\mathrm{pH} 10.0$, containing $2 \mathrm{mM} \mathrm{MgCl}$ and $10 \mathrm{mM}$ PNPP, at $37^{\circ} \mathrm{C}$, as described in Section 2, and $100 \%$ corresponds to $180.1 \mathrm{U} / \mathrm{ml}$ of initial activity.
GPI anchor structure. The method using polidocanol is based on the methodology described by Ciancaglini et al. (1990) and others who used it (Camolezi et al., 2002; Ierardi et al., 2002; Simão et al., 2007). The amount of solubilized enzyme activity was maximum, about $227 \%$, when polidocanol was used at a final concentration of $1 \%(\mathrm{w} / \mathrm{v})$ (Table 4$)$. Under these conditions, the PNPPase activity of the solubilized alkaline phosphatase was in the range of $409 \mathrm{U} / \mathrm{ml}$. It can be observed that the solubilization procedure using polidocanol stimulated the enzymatic activity of the enzyme and similar results were also obtained for the enzyme from rat osseous plate, as reported by Ciancaglini et al. (1990).

SDS-PAGE of membrane-bound alkaline phosphatase revealed diffuse protein bands after silver staining, but by assaying phosphomonohydrolase activity, only a distinct protein band was observed with $\mathrm{MW}_{\mathrm{r}}$ of about $120 \mathrm{kDa}$ (Fig. 4A), similar to that reported for alkaline phosphatases from other sources (Leone et al., 1997; Simão et al., 2007). However, this value is $17 \%$ smaller in comparison with that reported by Radisson et al. (1996) for osteoblastic alkaline phosphatase obtained from human bone cell cultures. This difference is not significant, since the enzyme is constituted by two subunits and this technique is not enough precise to differentiate very similar MWr. In addition, differences in the glycosylation level of the enzyme obtained from different sources and the use of diverse culture protocols may be the responsible for this behavior in SDS-PAGE.

When stained for phosphomonohydrolase activity, a single band of activity for solubilized enzyme with both PIPLC or polidocanol was observed on SDS-PAGE with $\mathrm{MW}_{\mathrm{r}}$ of about $120 \mathrm{kDa}$ (Fig. 4B), suggesting that this enzyme is a homodimer constituted of two apparently identical subunits of $\mathrm{MW}_{\mathrm{r}}$ $60 \mathrm{kDa}$ as described by several authors for the enzyme from other sources (Ciancaglini et al., 1990; Leone et al., 1997; Simão et al., 2007). These results prove that both solubilization procedures do not modify the structural and kinetic properties of the enzyme of human alveolar bone cells. 
Other enzymes also can be found in these membrane fractions such as NPP1 (or PC-1, NPP) and PHOSPHO1. NPP1 is also an integral protein with $130 \mathrm{kDa}$, with an optimum $\mathrm{pH}$ around 7.4-8.8 and does not respond to classical inhibitors of alkaline phosphatases. Also, PHOSPHO1, with a molecular mass around $32 \mathrm{kDa}$, has optimum $\mathrm{pH}$ around 6.7 (Anderson et al., 2004; Roberts et al., 2004). Considering that $\mathrm{pH} 10$ was used to monitor the PNPPase activity of membrane-bound alkaline phosphatase, we are excluding the possibility of the phosphomonohydrolase activity to be attributed to the enzymes described above.

The data presented here describe a protein with molecular mass of $120 \mathrm{kDa}$, with high levels of phosphomonohydrolase activity inhibited by classical inhibitors of alkaline phosphatases. The proposed method described here is simple, rapid and suitable to efficiently isolate membrane-bound alkaline phosphatase from cultures of osteoblastic cells from human alveolar bone. This membrane fraction can also be efficiently solubilized with PIPLC or polidocanol. Also, modifying the homogenization procedures and the buffers used in the kinetic measurements, this method could be used to study other enzymes involved in the mineralization process. It is important to emphasize the advantage of the considerable reduction in the time needed to obtain this membrane fraction in comparison with other methods usually used. This contributes to a smaller denaturing effect on the enzyme and to the comprehension of the mineralization process and also the role of alkaline phosphatase during this process.

\section{Acknowledgment}

The authors thank Priscila Cerviglieri for revision of the text. We also thank FAPESP and CNPq for the financial support given to our laboratory. AMSS received a FAPESP scholarship.

\section{References}

Anderson HC. Molecular biology of matrix vesicles. Clin Orthop Rel Res 1995;314:266-80.

Anderson HC. Matrix vesicles and calcification. Curr Rheumatol Rep 2003; 5:222-6.

Anderson HC, Sipe JB, Hessle L, Dhamyamraju R, Atti E, Camacho NP, et al. Impaired calcification around matrix vesicles of growth plate and bone in alkaline phosphatase-deficient mice. Am J Pathol 2004;164:841-7.

Anderson HC, Garimella R, Tague SE. The role of matrix vesicles in growth plate development and biomineralization. Front Biosci 2005;10:822-37.

Angrand M, Briolay A, Ronzon F, Roux B. Detergent-mediated reconstitution of a glycosyl-phosphatidylinositol-protein into liposomes. Eur J Biochem 1997;250:168-76.

Aubin JE, Turksen K, Heersche JNM. Osteoblastic cell lineage. In: Noda M, editor. Cellular and molecular biology of bone. San Diego: Academic Press; 1993. p. 1-45.

Beck Jr GR. Inorganic phosphate as a signaling molecule in osteoblast differentiation. J Cell Biochem 2003;90:234-43. doi:10.1002/jcb.10622.

Beck Jr GR, Sullivan EC, Moran E, Zerler B. Relationship between alkaline phosphatase levels, osteopontin expression, and mineralization in differentiating MC3T3-E1 osteoblasts. J Cell Biochem 1998;68:269-80. doi: 10.1002/(SICI)1097-4644(19980201)68:2〈269::AID-JCB13)3.0.CO;2-A.
Boyan BD, Schwartz Z, Boskey AL. The importance of mineral in bone and mineral research. Bone 2000;27:341-2.

Breitbart AS, Grande DA, Kessler R, Ryaby JT, Fitzsimmons RJ, Grant RT. Tissue engineered bone repair of calvarial defects using cultured periosteal cells. Plast Reconstr Surg 1998;101:567-74.

Camolezi FL, Daghastanli KRP, Magalhães PP, Pizauro JM, Ciancaglini P. Construction of an alkaline phosphatase-liposome system: a tool for biomineralization study. Int J Biochem Cell Biol 2002;34:1091-101. doi:10.1016/S1357-2725(02)00029-8.

Cheng SL, Zhang SF, Avioli LV. Expression of bone matrix proteins during dexamethasone-induced mineralization of human bone marrow stromal cells. J Cel Biochem 1996;61:182-93.

Ciancaglini P, Pizauro JM, Rezende AA, Rezende LA, Leone FA. Solubilization of membrane-bound matrix-induced alkaline phosphatase with polyoxyetylene 9-lauryl ether (polidocanol): purification and metalloenzyme properties. Int J Biochem 1990;22:385-92.

Ciancaglini P, Pizauro JM, Leone FA. Dependence of divalent metal ions on phosphotransferase activity of osseous plate alkaline phosphatase. J Inorg Biochem 1997;66:51-5. doi:10.1016/S0162-0134(96)00159-6.

Ciancaglini P, Simão AMS, Camolezi FL, Millán JL, Pizauro JM. Contribution of matrix vesicles and alkaline phosphatase to ectopic bone formation. Braz J Med Biol Res 2006;39:603-10. doi:10.1590/S0100-879X2006000500006.

Coelho MJ, Fernandes MH. Human bone cell cultures in biocompatibility testing. Part II: effect of ascorbic acid, beta-glycerophosphate and dexamethasone on osteoblastic differentiation. Biomaterials 2000;21:1095-102. doi:10.1016/S0142-9612(99)00192-1.

Curti C, Pizauro JM, Rossinholi G, Vugman I, Mello de Oliveira JA, Leone FA. Isolation and kinetic properties of an alkaline phosphatase from rat bone matrix-induced cartilage. Cell Mol Biol 1986;32:55-62.

Demenis MA, Leone FA. Kinetic characteristics of ATP hydrolysis by a detergent-solubilized alkaline phosphatase from rat osseous plate. IUBMB Life 2000;49:113-9.

Ferrera D, Poggi S, Biassoni C, Dickson GR, Astigiano S, Barbieri O, et al. Three-dimensional cultures of normal human osteoblasts: proliferation and differentiation potential in vitro and upon ectopic implantation in nude mice. Bone 2002;30:718-25.

Freemont AJ. Basic bone cell biology. Int J Exp Pathol 1993;74:411-6.

Garimella R, Bi X, Anderson H, Camacho N. Nature of phosphate substrate as a major determinant of mineral type formed in matrix vesicle-mediated in vitro mineralization: an FTIR imaging study. Bone 2006;38:811-7. doi:10.1016/j.bone.2005.11.027.

Hamade E, Azzar G, Radisson J, Buchet R, Roux B. Chick embryo anchored alkaline phosphatase and mineralization process in vitro. Eur J Biochem 2003;270:2082-90. doi:10.1046/j.1432-1033.2003.03585.x.

Harrison G, Shapiro IM, Golub EE. The phosphatidylinositol-Glycolipid anchor on alkaline phosphatase facilitates mineralization initiation in vitro. J Bone Miner Res 1995;10:568-73.

Hartree EF. Determination of protein: a modification of the Lowry method that gives a linear photometric response. Anal Biochem 1972;48:422-7. doi:10.1016/0003-2697(72)90094-2.

Haynesworth SE, Goshima J, Goldberg VM, Caplan AI. Characterization of cells with osteogenic potential from human marrow. Bone 1992;13:81-8. doi:10.1016/8756-3282(92)90364-3.

Hsu HHT, Anderson HC. A role for ATPase in the mechanisms of ATPdependent $\mathrm{Ca}$ and phosphate deposition by isolated rachictic matrix vesicles. Int J Biochem Cell Biol 1995;27:1349-56. doi:10.1016/13572725(95)00103-V.

Hsu HHT, Anderson HC. Evidence of the presence of a specific ATPase represible for ATP-initiated calcification by matrix vesicles isolated from cartilage and bone. J Biol Chem 1996;271:26383-8.

Hsu HHT, Camacho NP, Anderson HC. Further characterization of ATP-initiated calcification by matrix vesicles isolated from rachitic rat cartilage. Membrane perturbation by detergents and deposition of calcium pyrophosphate by rachitic matrix vesicles. Biochim Biophys Acta 1999;1416: 320-32. doi:10.1016/S0005-2736(98)00235-1.

Hsu HHT, Tawfik O, Sun F. Effects of lectins on calcification by vesicles isolated from aortas of cholesterol-fed rabbits. Biochim Biophys Acta 2000;1464:262-72. doi:10.1016/S0005-2736(00)00150-4. 
Hunter GK, Holmyard DP, Pritzker KP. Calcification of chick vertebral chondrocytes grown in agarose gels: a biochemical and ultrastructural study. J Cell Sci 1993;104:1031-8.

Ibaraki K, Termine JD, Whitson SW, Young MF. Bone matrix mRNA expression in differentiating fetal bovine osteoblasts. J Bone Miner Res 1992;7: 743-54.

Ierardi DF, Pizauro JM, Ciancaglini P. Erythrocyte ghost cell-alkaline phosphatase: construction and characterization of a vesicular system for use in biomineralization studies. Biochim Biophys Acta 2002;1567:183-92. doi:10.1016/S0005-2736(02)00615-6.

Kirsch T, Claassen H. Matrix vesicle mediate mineralization of human thyroid cartilage. Calcif Tissue Int 2000;66:292-7. doi:10.1007/s002230010059.

Kirsch T, Harrison G, Worch KP, Golub EE. Regulatory roles of zinc in matrix vesicle-mediated mineralization of growth cartilage. J Bone Miner Res 2000; $15: 261-70$.

Krupnick AS, Shaaban A, Radu A, Flake AW. Bone marrow tissue engineering. Tissue Eng 2002;8:145-55.

Laemmli UK. Cleavage of structural proteins during the assembly of the head bacteriophage T4. Nature (London) 1970;227:680-5.

Leone FA, Pizauro JM, Ciancaglini P. Rat osseous plate alkaline phosphatase: a search for its role in biomineralization. Trends Comp Biochem Physiol 1997;3:57-73.

Leone FA, Baranauskas JA, Furriel RPM, Borin IA. SigrafW: an easy-to-use program for fitting enzyme kinetic data. Biochem Molec Educ 2005; 33:399-403.

Lowry OH, Rosebrough NJ, Farr AL, Randall RJ. Protein measurement with the Folin phenol reagent. J Biol Chem 1951;193:265-75.

Mailhot JM, Borke JL. An isolation and in vitro culturing method for human intraoral bone cells derived from dental implant preparation sites. Clin Oral Implants Res 1998;9:43-50. doi:10.1034/j.1600-0501.1998. 090106.x.

Matsuzawa T, Anderson HC. Phosphatases of epiphyseal cartilage studied by electron microscopic cytochemical methods. J Histochem Cytochem 1971; 19:801-8.

Millán JL. Mammalian alkaline phosphatases: from biology to applications in medicine and biotechnology. Weinheim: Wiley-VCH Verlag; 2006.

Narisawa S, Frohlander N, Millan JL. Inactivation of two mouse alkaline genes and establishment of a model of infantile hypophosphatasia. Dev Dyn 1997;208:432-46. doi: 10.1002/(SICI)1097-0177(199703)208:3〈432:: AID-AJA13>3.0.CO;2-1.

Osyczka AM, Leboy PS. Bone morphogenetic protein regulation of early osteoblast genes in human marrow stromal cells is mediated by extracellular signal-regulated kinase and phosphatidylinositol 3-kinase signaling. Endocrinology 2005;146:3428-37. doi:10.1210/en.2005-0303.

Owen TA, Aronow M, Shalhoub V, Barone LM, Wilming L, Tassinari MS, et al. Progressive development of the rat osteoblast phenotype in vitro: reciprocal relationships in expression of genes associated with osteoblast proliferation and differentiation during formation of the bone extracellular matrix. J Cell Physiol 1990;143:420-30.

Phinney DG. Building a consensus regarding the nature and origin of mesenchymal stem cells. J Cel Biochem Sup 2002;38:7-12.

Pizauro JM, Curti C, Ciancaglini P, Leone FA. Triton X-100 solubilized bone matrix-induced alkaline phosphatase. Comp Biochem Physiol 1987;87B: 921-6.

Pizauro JM, Ciancaglini P, Leone FA. Phosphotransferase activity associated with rat osseous plates alkaline phosphatase: a possible role in biomineralization. Int J Biochem 1992;24:1391-6.

Pizauro JM, Ciancaglini P, Leone FA. Osseous plate alkaline phosphatase is anchored by GPI. Braz J Med Biol Res 1994;27:453-6.
Pizauro JM, Ciancaglini P, Leone FA. Characterization of the phosphatidylinositol-specific phospholipase C-released form of rat osseous plate alkaline phosphatase and its possible significance on endochondral ossification. Mol Cell Biochem 1995;152:121-9.

Prockop DJ, Gregory CA, Spees JL. One strategy for cell and gene therapy: harnessing the power of adult stem cells to repair tissues. Proc Natl Acad Sci U S A 2003;100:11917-23. doi:10.1073/pnas.1834138100.

Radisson J, Angrand M, Chavassieux P, Roux B, Azzar G. Differential solubilization of osteoblastic alkaline phosphatase from human primary bone cell cultures. Int J Biochem Cell Biol 1996;28:421-30. doi:10.1016/13572725(95)00160-3.

Reddy GK, Enwemeka CS. A simplified method for the analysis of hydroxyproline in biological tissues. Clin Biochem 1996;29:225-9. doi:10.1016/ 0009-9120(96)00003-6.

Rezende AA, Pizauro JM, Ciancaglini P, Leone FA. Phosphodiesterase activity is a novel property of alkaline phosphatase from osseous plate. Biochem $\mathbf{J}$ 1994;301:517-22.

Rezende LA, Ciancaglini P, Pizauro JM, Leone FA. Inorganic pyrophosphatephosphohydrolytic activity associated with rat osseous plate alkaline phosphatase. Cell Mol Biol 1998;44:293-302.

Roberts SJ, Stewart AJ, Sadler PJ, Farquharson C. Human PHOSPHO1 exhibits high specific phosphoethanolamine and phosphocholine phosphatase activities. Biochem J 2004;382:59-65.

Rosa AL, Beloti MM. Effect of cpTi surface roughness on human bone marrow cell attachment, proliferation, and differentiation. Braz Dent $\mathbf{J}$ 2003;14:16-21. doi:10.1590/S0103-64402003000100003.

Say JC, Ciuffi K, Furriel RPM, Ciancaglini P, Leone FA. Alkaline phosphatase from rat osseous plate: purification and biochemical characterization of a soluble form. Biochim Biophys Acta 1991;1074:256-62.

Say JC, Furriel RPM, Ciancaglini P, Jorge JA, Lourdes M, Polizeli TM, et al. Conidial alkaline phosphatase from Neurospora crassa. Phytochemistry 1996;41:71-5. doi:10.1016/0031-9422(95)00534-X.

Scutt A, Bertram P, Brautigam M. The role of glucocorticoids and prostaglandin E2 in the recruitment of bone marrow mesenchymal cells to the osteoblastic lineage: positive and negative effects. Calcif Tissue Int 1996;59:154-62. doi:10.1007/s002239900102.

Simão AM, Beloti MM, Cezarino RM, Rosa AL, Pizauro JM, Ciancaglini P. Membrane-bound alkaline phosphatase from ectopic mineralization and rat bone marrow cell culture. Comp Biochem Physiol A Mol Integr Physiol 2007;146:679-87. doi:10.1016/j.cbpa.2006.05.008.

Stein GS, Lian JB, Owen TA. Relationship of cell growth to the regulation of tissue-specific gene expression during osteoblast differentiation. FASEB J 1990; $13: 3111-23$.

Sugawara Y, Suzuki K, Koshikawa M, Ando M, Iida J. Necessity of enzymatic activity of alkaline phosphatase for mineralization of osteoblastic cells. Jpn J Pharmacol 2002;88:262-9.

Waymire KG, Mahuren JD, Jaje JM, Guilarte TR, Coburn SP, McGregor GR. Mice lacking tissue non-specific alkaline phosphatase die from seizure due to defective metabolism of vitamin B-6. Nat Genet 1995;11:45-51. doi:10.1038/ng0995-45.

Whyte MP. Hypophosphatasia and the role of alkaline phosphatase in skeletal mineralization. Endocr Rev 1994;15:439-61. doi: 0163-769X/94/15040439\$03.00/0\$03.00/0.

Whyte MP. Hypophosphatasia: nature's window on alkaline phosphatase in man. In: Bilezikian JP, Raisz LG, Rodan GA, editors. Principles of bone biology. San Diego: Academic Press; 1996. p. 951-68.

Xiao Y, Qian H, Young WG, Bartold PM. Tissue engineering for bone regeneration using differentiated alveolar bone cells in collagen scaffolds. Tissue Eng 2003;9:1167-77. 